\title{
Vruchtgebruik op aandelen : over de grenzen van goederenrecht, erfrecht en vennootschapsrecht : een wetenschappelijke proeve op het gebied van de rechtsgeleerdheid
}

Citation for published version (APA):

Bos, E. C. (2005). Vruchtgebruik op aandelen : over de grenzen van goederenrecht, erfrecht en vennootschapsrecht : een wetenschappelijke proeve op het gebied van de rechtsgeleerdheid. [Doctoral Thesis, Maastricht University]. Kluwer. https://doi.org/10.26481/dis.20051216eb

Document status and date:

Published: 01/01/2005

DOI:

$10.26481 /$ dis.20051216eb

Document Version:

Publisher's PDF, also known as Version of record

Please check the document version of this publication:

- A submitted manuscript is the version of the article upon submission and before peer-review. There can be important differences between the submitted version and the official published version of record. People interested in the research are advised to contact the author for the final version of the publication, or visit the DOI to the publisher's website.

- The final author version and the galley proof are versions of the publication after peer review.

- The final published version features the final layout of the paper including the volume, issue and page numbers.

Link to publication

\footnotetext{
General rights rights.

- You may freely distribute the URL identifying the publication in the public portal. please follow below link for the End User Agreement:

www.umlib.nl/taverne-license

Take down policy

If you believe that this document breaches copyright please contact us at:

repository@maastrichtuniversity.nl

providing details and we will investigate your claim.
}

Copyright and moral rights for the publications made accessible in the public portal are retained by the authors and/or other copyright owners and it is a condition of accessing publications that users recognise and abide by the legal requirements associated with these

- Users may download and print one copy of any publication from the public portal for the purpose of private study or research.

- You may not further distribute the material or use it for any profit-making activity or commercial gain

If the publication is distributed under the terms of Article 25fa of the Dutch Copyright Act, indicated by the "Taverne" license above, 
VRUCHTGEBRUIK OP AANDELEN 
SERIE VAN WEGE HET

VAN DER HEIJDEN INSTITUUT TE NIJMEGEN

ONDER LEIDING VAN

PROF. MR. J.M.M. MAEIJER

PROF. MR. H.M.N. SCHONIS

PROF. MR. F.J.P. VAN DEN INGH

PROF. MR. G. VAN SOLINGE

PROF. MR. M. VAN OLFFEN

PROF. MR. M.P. NIEUWE WEME

DEEL 84 


\section{VRUCHTGEBRUIK OP AANDELEN}

Over de grenzen van goederenrecht, erfrecht en vennootschapsrecht

Een wetenschappelijke proeve op het gebied van de rechtsgeleerdheid

\section{PROEFSCHRIFT}

Ter verkrijging van de graad van doctor aan de Universiteit Maastricht

op gezag van de Rector Magnificus Prof. mr. G.P.M.F. Mols volgens besluit van het College van Decanen

in het openbaar te verdedigen op vrijdag 16 december 2005

des namiddags on 13.45 uur precies

door

Erwin Christiaan Bos

KLUWER

DEVENTER - 2005 
Promotores:

Prof. mr. C.A. Schwarz

Dr. mr. Ju.A. Hamers

Manuscriptcommissie:

Prof. mr. G.R. de Groot

Prof, mr. T. Hartlief

Prof. mr. FJ.P. van den Ingh

Prof. mr. M.J.A. van Mourik

Radboud Universiteit Nijmegen

Prof. mr. G.T.M.J. Raaijmakers

Radboud Universiteit Nijmegen

ISBN $90-13-03151-\mathrm{X}$

2005, E.C. Bos, Leiden

Alle rechten woorbehouden. Niets uit deze uitgave mag zonder voorafgaande toestemming van de uitgever worden verweelwoudigd of openbaar gemaakt.

Voor zover het maken van kopieën uit deze uitgave is toegestaan op grond van art. $16 \mathrm{~b}$ Auteurswet 1912 jo. het Besluit van 20 juni 1974, Stb. 351 , zoals gewijzigd bij Besluit van 23 aug. 1985 , Stb. 471 , en art. 17 Auteurswet 1912 , dient men de daarvoor wettelijk verschuldigde vergoedingen te voldoen aan de Stichting Reproredit Hoofddorp (Postbus 3051, $2130 \mathrm{~KB}$ ).

Hoewel aan de totstandkoming van deze de uiterste zorg is besteed, aanvaarden de auteur(s), redacteur(en) en uitgever(s) geen aansprakelijkheid voor eventuele fouten en onwolkomenheden, noch voor gevolgen hiervan.

KJuwer BV legt de gegevens van abonnees vast voor de uitwoering van de (abonnements)overeenkomst. De gegevens kunnen door Kluwer, of zorgvuldig geselecteerde derden, worden gebruikt om u te informeret over relevante producten en diensten. Indien u hier bezwaar tegen heeft, kunt $u$ contact met ons opnemen.

Op alle utitgaven van Kluwer zijn de algemene leveringsvoorwaarden van toepassing. Deze kunt u lezen op wwwkluwernal of opwragen via telefoonnummer 0570-6734 49 . 
'Wetenschap. Wat is wetenschap? Wetenschap is de titanische poging van het menselijk intellect zich uit zijn kosmische isolement te verlossen door te begrijpen!'

"Nooit meer slapen" (1966)

W.F Hermans 



\section{VOORWOORD}

Op 16 december 2005 verdedigde aan de Universiteit Maastricht Mr. E.C. Bos zijn proefschrift, getiteld V ruchtgebruik op aandelen. Promotores waren Prof.mr. C.A. Schwarz en Dr. Mr. J.J.A Hamers.

Deze studie omvat een rechtsgebiedoverschrijdend onderzoek naar het vruchtgebruik op een aandeel in een kapitalvennootschap. Het onderzoek spitst zich toe op bepaling van de plaats van de vruchtgebruiker op cen aandeel in de vennootschappelijke context.

De vestiging van het recht van vruchtgebruik op aandelen roept tal wan viagen op. Bos richt zijn aandacht op de herkomst en functie van het wruchtgebruik zoals deze naar huidig Nederlands recht zijn vormgegeven. Daarbij wordt in het bijzonder aandacht besteed aan de rol van deze figur in het sinds 2002 vigerende erfrecht.

Het onderwerp is voor de ondernemingsrechtelijke praktijk in brede zin van belang. De rechtspositie van de vruchtgebruiker kan zowel bij het ontstaan (vestiging) van het vruchtgebruik worden gedefinieerd, alsook aanvullend vorm worden gegeven door de statuten van de vennootschap. Bovendien kan de vruchtgebruiker een rol van betekenis spelen bij de besluitvorming binnen de kapitaalvennootschap.

Het wruchtgebruik neemt een prominente plaats in binnen het systeem van het goederenrecht. De vestiging van het recht van vruchtgebruik, alsmede de dogmatische figuur van het voorbehouden vruchtgebruik, passeren de revue. Bijzondere problemen inzake de vestigingshandelingen komen aan bod. Bos voorziet in een specifieke analyse van de goederenrechtelijke vrucht en komt tot de conclusie dat de tijd rijp is voor verdere ontwikkeling van het vruchtbegrip. Daarnaast bespreekt hij de figuur van substitutie en de dogmatische achtergrond van de door de Hoge Raad aanvaarde directe verkrijgingsleer.

Alvorens de vennootschapsrechtelijke positie van de vruchtgebruiker op aandelen tegen het licht te houden, wordt de achtergrond geschetst van het ontstaan van het recht van vruchtgebruik. Het huidige erfrecht is in hoofdzaak specifiek gericht op de verzorging van de langstlevende echtgenoot. Daarbij is een belangrijke rol weggelegd voor het vruchtgebruik als rechtsinstrument. Bos beziet hoe deze rol zich verhoudt met het aandeel in een kapitaalvennootschap en concludeert onder meer dat het verzorgingsvruchtgebruik niet behoort te worden gefrustreerd door de saisine of een (erfrechtelijke) blokkeringsregeling. Daarop aansluitend wolgt een verhandeling van de juridisch-technische stappen voor de vestiging van een recht van vruchtgebruik op een aandeel in een kapitaalvennootschap. Naast de eisen van het vennootschapsrecht, besteedt schrijver aandacht aan de figuur van de WGE en haar implicaties voor het vuchtgebruik op aandelen. Hij komt tot de conclusie dat de complexe figuur van de 
gemeenschap, welke als basis dient voor de $W_{\mathrm{GE}}$, tot gevolg heeft dat de vruchtgebruiker een deel van zijn goederenrechtelijke bescherming verliest.

Een belangrijk deel van het onderzoek richt zich op de positie van de vruchtgebruiker in het vennootschapsrecht. Specifieke vraagstukken met betrekking tot de vrucht van het aandeel en de belangrijke rol van het stemrecht komen voor het voetlicht. Bos concludeert dat de aandeelhouder zijn vrijheid beperkt ziet door de aanwezigheid van de vruchtgebruiker Niet alleen blijkt zulks uit de rol van de vruchtgebruiker bij de besluitvorming in de vennootschap, maar ook blijkt uit de regelingen omtrent geschillen, tuitkoop, fusie en splitsing dat de vruchtgebruiker en aandeelhouder juridisch sterk verbonden zijn. Op goede gronden betoogt hij dat de aandeelhouder in zijn stemuitoefening alsook in de uitoefening van zijn andere lidmaatschapsrechten het belang van de aan hem verbonden vruchtgebruiker niet kan negeren. Voorts betrekt hij de stelling dat de nu bestaande gelijkschakeling van pandhouders en vruchtgebruikers met de positie van de bewilligde certificaathouders zijn houdbaarheidsdatum heeft overschreden.

Ten slotte plaatst Bos cle relatie tussen vruchtgebruiker, aandeelhouder en vennootschap in de sléutel van enkele aanpalende rechtsverhoudingen. Naar zijn mening vertonen de figuren van de economische eigendom, de certificering van aandelen en de trust een grote gelijkenis. Hij is van mening dat de juridische relatie tussen vruchtgebruiker en aandeelhouder gebaat kan zijn bij het introduceren van de in deze rechtsverhoudingen heersende opvattingen.

Wij zijn verheugd dit proefschrift in onze serie te kunnen opnemen, vooral ook gegeven het praktisch belang van dit werk.

\author{
J.M.M. Maeijer \\ H.M.N. Schonis \\ F.J.P. wan den Ingh \\ $G$. van Solinge \\ M. wan Olffen \\ M.P. Nienwe Weme
}




\section{INHOUDSOPGAVE}

Lijst van gebruikte afkortingen

\section{Hoofdstuk 1 Inleiding}

1.1. Onderwerp van onderzoek

1.2. Verantwoording

1.3. Plan van behandeling

\section{Hoofdstuk 2 Vruchtgebruik}

2.1. Het recht van vruchtgebruik

2.1.1. Plaats in het vermogensrecht 5

2.1.2. Definitie 6

2.2. Ontstaan van het vruchtgebruik 6

2.2.1. Vestiging

2.2.1.1. Inleiding

2.2.1.3. Beschikkingsbevoegdheid 7

2.2.1.4. Levering: vestiging : 8

2.2.2. Overdracht onder woorbehoud van vruchtgebruik 10

$\begin{array}{ll}\text { 2.2.3. Verjaring } & 12\end{array}$

2.3. Duur van het vruchtgebruik $\quad 13$

2.3.1. Het leven van de vruchtgebruiker 13

2.3.2. Gezamenlijk vruchtgebruik 13

$\begin{array}{ll}\text { 2.3.3. Opvolgend vruchtgebruik } & 14\end{array}$

2.3.4. De rechtspersoon als vruchtgebruiker $\quad 14$

2.3.5. Einde van het vruchtgebruik , 14

2.4. Rechten van de vruchtgebruiker 15

2.4.1. Recht op de vruchten 15

2.4.1.1. Inleiding 15

2.4.1.2. Verkeersopvatting 16

$\begin{array}{ll}\text { 2.4.1.3. De afgesproken wrucht } & 18\end{array}$

2.4.1.4. Verkrijging van de vrucht 19

2.4.1.5. Resumerend: de burgerlijke vrucht 19

2.4.2. Gebruiken of verbruiken 20

2.4.3. Beheren 2\| $2 \|$ 
2.4.4. Beschikken 22

2.4.4.1. Inleiding 22

2.4.4.2. Vervreemden naar bestemming 22

2.4.4.3. Uitbreiding van de beschikkingsbevoegdheid 24

2.4.4.4. Vervreemden en verteren : 24

2.4.5. Beschikken over een goed van een derde 25

2.5. Plichten van de vruchtgebruiker 26

2.5.1. 'Goed vruchtgebruikerschap' - artikel 3:207 lid 3 26

2.5.2. Enkele andere verplichtingen 27

2.5.3. 'Ernstig tekortschieten' - artikel 3:221 28

2.6. Substitutie 29

2.6.1. Inleiding 29

2.6.2. Bevoegdelijk beschikken 30

2.6.3. 'behoort de hoofdgerechtigde toe' 30

2.6.3.1. De leer van de directe verkrijging en substitutie 31

2.6.3.2. Conclusie 37

2.6.4. 'is eveneens aan het vruchtgebruik onderworpen' $\quad 37$

2.6.5. Financiering uit het vermogen van de vruchtgebruiker 38

2.6.6. Onbevoegdelijk beschikken 38

2.7. Conclusie 39

\section{Hoofdstuk 3 Vruchtgebruik en erfrecht}

3.1. Inleiding

3.2. Vruchtgebruik onder het oude erfrecht 42

3.2.1. Het vruchtgebruiktestament 43

3.2.2. Legaat van vruchtgebruik op een specifiek goed 45

3.3. Vruchtgebruik in het nieuwe erfrecht 45

3.3.1. Nieuw erfrecht 45

3.3.1.1. Het versterferfrecht 46

3.3.1.2. Het testamentair erfrecht 48

3.4. Het voorbehouden vruchtgebruik bij uitoefening van wilsrechten 50

3.4.1. De wilsrechten: inleiding 50

3.4.2. De goederen 53

3.4.3. Het voorbehouden vruchtgebruik: uitzonderingen op titel $3.8 \quad 54$

3.4.4. Het voorbehouden vruchtgebruik op aandelen ex artikel 4:19 en 4:21 57

3.5. Het verzorgingsvruchtgebruik $\quad 57$

$\begin{array}{ll}3.5 .1 \text {. Inleiding } & 57\end{array}$

3.5.2. De keuzevrijheid ten aanzien van de goederen 58

3.5.3. De verzorgingsbehoefte 59

3.5.4. Het verzorgingsvruchtgebruik: de artikelen 4:31 en 4:33 60

3.5.5. Het vruchtgebruik op aandelen ter verzorging 61 
3.6. Het vruchtgebruik in testamentaire beschikkingen

3.6.1. Inleiding

61

3.6.2. Het legaat van vruchtgebruik

61

3.6.3. Voorwaardelijke makingen: onder tijdsbepaling en onder voorwaarde

62

3.6.3.1. Making onder tijdsbepaling: conversie

3.6.3.2. Making onder voorwaarde: van overeenkomstige toepassing

3.7. Vererving van aandelen en de erfrechtelijke blokkade

3.7.1. Inleiding: de statutaire erfrechtelijke blokkade

3.7.2. Versterferfrecht: de wettelijke verdeling en het voorbehouden vruchtgebruik

3.7.3. Testamentair erfrecht 66

3.7.3.1. Inleiding 66

3.7.3.2. Erfgenaam en erfstelling $\quad 66$

$\begin{array}{lll}3.7 .3 .3 \text {. Legaat } & 67\end{array}$

3.7.3.4. Verzorgingsvruchtgebruik 67

3.7.4. Aandeelhoudende erfgenamen 69

3.7.4.1. Inleiding 69

3.7.4.2. Blokkering van aandelen en de saisine $\quad 70$

$\begin{array}{ll}3.7 .4 .3 \text {. Verzorgingsvruchtgebruik } & 71\end{array}$

3.8. Conclusie

\section{Hoofdstuk 4 Vruchtgebruik op een aandeel}

4.1. Inleiding 75

4.2. Vestiging 75

4.2.1. Inleiding $\quad 75$

4.2.2. Overdracht, vestiging en levering: terminologie 76

4.3. Aandeel op naam in een BV 77

$\begin{array}{ll}\text { 4.3.1. Inleiding } & 77\end{array}$

4.3.2. Vestigingshandeling: notariële akte 78

4.3.3. Erkenning en het aandeelhoudersregister 78

4.3.3.1. Erkenning van de vestiging 78

4.3.3.2. Procedure - - 81

4.3.4. Vestiging en blokkeringsregeling 82

4.4. Aandeel op naam in een beursgenoteerde NV 82

$\begin{array}{ll}\text { 4.4.1. Inleiding } & 82\end{array}$

4.4.2. Aandeel op naam: artikel 2:86c 84

4.5. Aandeel aan toonder 84

4.5.1. Inleiding: onafwendbaar afscheid van het toonderbewijs 84

$\begin{array}{ll}\text { 4.5.2. Vestiging } & 87\end{array}$

4.5.3. Terhandstelling: artikel 3:90 lid I 87 
4.5.4. Bewaargeving

4.5.4.1. Geindividualiseerde bewaargeving: traditio longa manu

4.5.4.2. Niet-geïndividualiseerde bewaargeving: het VABEF-systeem

4.5.5. Het systeem van de Wge

4.5.5.1. De Wge: algemeen

4.5.5.2. De Wge: goederenrechtelijke aspecten ter discussie

4.5.5.3. De Wge: vestiging krachtens artikel 23

4.5.5.4. De goederenrechtelijke positie van de vruchtgebruiker op een aandeel in de Wge

4.5.5.5. De vennootschapsrechtelijke positie van de vruchtgebuiker op een aandeel in de Wge

4.6. Conclusie

\section{Hoofdstuk 5 Vruchtgebruiker - aandeelhouder}

5.1. Inleiding

5:2. Het rechtskatakter en de aard van aandeelhouderschap en aandeel

5:2.1. Inleiding

5.2.2. Vermogensaspect

5.2.3. Zeggenschapsaspect

5.2.4. Het lidmaatschap: onderscheid tussen de BV en de NV 102

5.2.5. Verhouding tussen vermogen en zeggenschap 103

5.2.6. Conclusie 104

5.3. De bestemming van een aandeel 105

5.3.1. Bestemming door de aandeelhouder 105

5.3.2. Verandering van bestemming 106

5.4. Sûr place: aard en bestemming van aandeelhouderschap en aandeel 107

5.5. De bevoegdheden krachtens goederenrecht en erfrecht. Een reprise 107

$\begin{array}{ll}\text { 5.5.1. De vrucht van een aandeel } & 108\end{array}$

$\begin{array}{ll}\text { 5.5.1.1. Inleiding } & 108\end{array}$

5.5.1.2. Jurisprudentie 108

5.5.1.3. De vrucht van een aandeel nader beschouwd 113

5.5.2. De bevoegdheid tot gebruik, verbruik en beheer $\quad 114$

5.5.2.1. Gebruik en verbruik 115

5.5.2.2. Beheer 115

5.5.2.3. Afsluitend 118

5.5.3. De bevoegdheid tot beschilkking, vervreemding en vertering 119

5.5.3.1. Inleiding 119

5.5.3.2. Vervreemding naar bestemming 120

5.5.3.3. Uitbreiding van de beschikkingsbevoegdheid van de vruchtgebruiker 120

5.5.3.4. Vervreemden en verteren 122 
5.5.3.5. Afsluitend

5.5.4. De beschikkingsbevoegde vruchtgebruiker

5.5.4.1. De vruchtgebruiker beschikt over een aandeel in een BV. Collisie

5.5.4.2. De vruchtgebruiker beschikt over een aandeel in een $\mathrm{NV}$

5.6. Conclusie

\section{Hoofdstuk 6 Vruchtgebruiker - vennootsehap}

6.1. Inleiding

6.2. Bevoegdhedien krachtens vennootschapsrecht

6.2.1. Inleiding: het stemrecht

6.2.1.1. Stemrecht van de vruchtgebruiker en de beslotenheid van de BV

6.2.1.2. Stemrecht van de vruchtgebruiker en de NV

6.2.1.3. Uitzondering op de hoofdregel. Vruchtgebruik bij wilsrechten

6.2.1.4. Geen goedkeuring: volmacht

6.2.1.5. Overdracht of overgang van vruchtgebruik en het stemrecht

6.2.1.6. Conclusie

6.2.2. Lidmaatschapsrechten. De gelijkstelling met de bewilligd certificaathouder

6.2.2.1. Inleiding

6.2.2.2. Rechten van de certificaathouder

6.2.2.3. Gelijkschakeling op grond van artikel $2: 88$ en $2: 197$

6.3. De kring van artikel $2: 8$

6.3.2. Een mogelijke uitwerking van artikel $2: 8$ - het winstbesluit

6.3.2.2. Het winstbesluit en de vruchtgebruiker

\subsubsection{Conclusie}

6.4.1. Inleiding

6.4.2. Uitstoting

6.4.3. Uittreding

6.4.4. Ontneming van stemrecht 153

6.4.5. De procedure 153

6.5. De uitkoopregeling 
6.6. De juridische fusie en splitsing 155

6.6.1. Inleiding 155

6.6.2. Juridische fusie: substitutie en inzage $\quad 156$

$\begin{array}{ll}\text { 6.6.3. Juridische splitsing: idem } 157 & 156\end{array}$

6.6.4. Behoud van lidmaatschapsrechten bij fusie en splitsing 158

6.6.4.1. Inleiding 158

6.6.4.2. Juridische fusie en splitsing en het behoud van stemrecht

158

6.6.4.3. Juridische fusie en splitsing en het behoud van certificaathoudersrechten

6.7. Conclusie

\section{Hoofdstuk 7 Drie laterale verkenningen}

7.1. Inleiding

7.2. Economisch eigendom en vruchtgebruik $\quad 164$

7.2.1. Inleiding

164

7.2.2. Economisch eigendom

7.2.3. Elementen van economisch eigendom en vruchtgebruik

7.3. Certificering en vruchtgebruik

7.3.1. Inleiding

7.3.2. Certificering van aandelen: een korte introductie 170

$\begin{array}{ll}\text { 7.3.3. De rechtsverhouding met de aandeelhouder } & 171\end{array}$

7.3.3.1. Certificaathouder en aandeelhouder $\quad 171$

7.3.3.2. Vruchtgebruiker en aandeelhouder 172

7.3.4. De rechtsverhouding aandeelhouder - vennootschap 173

$\begin{array}{ll}\text { 7.3.5. De rechtsverhouding met de vennootschap } & 174\end{array}$

7.3.5.1. Certificaathouder en vennootschap 174

7.3.5.2. Vruchtgebruiker en vennootschap 174

7.3.6. Conclusie

$\begin{array}{ll}\text { 7.4. De trustverhouding in het Zuid-Afrikaanse recht } & 176 \\ \text { 7.4.1. Inleiding: de trust in het algemeen. } & 176\end{array}$

7.4.2. De wording van de Zuid-Afrikaanse 'testamentary trust' 177

7.4.3. De relatie tussen de trustee en de beneficiary 178

7.4.3.1. Algemeen 178

7.4.3.2. Bijzondere verplichtingen inzake aandelen in kapitaalvennootschappen $\quad 179$

7.4.4. De vergelijking tussen trust en vruchtgebruik 180

7.5. Conclusie 181

Hoofdstuk 8 Samenvatting, conclusies en aanbevelingen : 183 
Bijlage A Statuten beursgenoteerde vennootschappen: $\mathrm{AEX}$

Bijlage B Statuten beursgenoteerde vennootschappen: AMX

Lijst van geraadpleegde literatuur

195

Trefwoordenregister

Jurisprudentieregister

Curriculum vitae 
. . . 


$\begin{array}{ll}\text { AA } & \text { Ars Aequi } \\ \text { aant. } & \text { aantekening } \\ \text { A-G } & \text { Advocaat Generaal } \\ \text { art. } & \text { artikel(en) } \\ \text { AvA } & \text { Algemene Vergadering van Aandeelhouders } \\ \text { a.w. } & \text { aangehaald werk } \\ \text { BV } & \text { besloten vennootschap } \\ \text { BW } & \text { Burgerlijk Wetboek } \\ \text { diss. } & \text { dissertatie } \\ \text { eds. } & \text { editors } \\ \text { HR } & \text { Hoge Raad } \\ \text { Inv. } & \text { Invoering } \\ \text { JOR } & \text { Jurisprudentie Onderneming \& Recht } \\ \text { KG } & \text { Kort Geding } \\ \text { KNB } & \text { Koninklijke Notariële Beroepsorganisatie } \\ \text { m.nt. } & \text { met noot } \\ \text { MvA } & \text { Memorie van Antwoord } \\ \text { MvJ } & \text { Minister van Justitie } \\ \text { MvT } & \text { Memorie van Toelichting } \\ \text { Mon.NBW } & \text { Monografieën Nieuw BW } \\ \text { NJ } & \text { Nederlandse Jurisprudentie } \\ \text { NJB } & \text { Nederlands Juristenblad } \\ \text { nr. } & \text { nummer(s) } \\ \text { NRC } & \text { NRC Handelsblad } \\ \text { NTBR } & \text { Nederlands Tijdschrift voor Burgerlijk Recht } \\ \text { NV } & \text { naamloze vennootschap } \\ \text { OBV } & \text { ouderlijke boedelverdeling } \\ \text { OK } & \text { Ondernemingskamer van het Gerechtshof te Amsterdam } \\ \text { p. } & \text { pagina } \\ \text { Parl. Gesch. } & \text { Parlementaire Geschiedenis } \\ \text { PbEG } & \text { Publicatieblad EG } \\ \text { Pres.Rb. } & \text { President van de rechtbank } \\ \text { Proc.Gen } & \text { Procureur Generaal } \\ q . q . & \text { qualitate qua } \\ \text { Rb. } & \text { Rechtbank } \\ \text { red. } & \text { redactie } \\ \end{array}$


Wha way gebrukle afkorhingen

KG Kort Geding

RM Themis Rechtsgeleerd Magazijn Themis

ro. rechtsoverweging

RvC Raad van Commissarissen

Sec. Section

Stb. Staatsblad

RvdW Rechtspraak van de Week

TM Toelichting Meijers

TVE Tijdschrift woor Effectenrecht

TwOB Tijdschrift voor Ondernemingsbestur

V\&O Vennootschap \& Onderneming

WFR Weekblad voor Fiscaal Recht

Wge Wet Giraal Effectenverkeer

WPNR Weekblad voor Privaatreclit, Notariaat en Registratie 


\section{Hoofdstuk 1}

\section{INLEIDING}

\subsection{Onderwerp van onderzoek}

Van alle beperkte rechten die het Nederlandse goederenrecht rijk is, is het recht van vruchtgebruik zonder twijfel het meest veelzijdige en meest complexe beperkte recht. Op verschillende punten komen de veelzijdigheid en de complexiteit van het vruchtgebruik naar voren. Om te beginnen is het recht van vruchtgebruik het enige beperkt recht dat gevestigd kan worden op alle soorten goederen. Reeds in 1923 schreef VAN RIESEN bijvoorbeeld een dissertatie over de combinatie van vruchtgebruik en effecten. ${ }^{\prime}$ Op het punt van de bevoegdheden van de vrucht-gebruiker kent het Nederlandse recht zelfs een uniek aspect: de vruchtgebruiker kan in staat worden gesteld het bezwaarde goed te verbruiken. Pogingen om het recht van vruchtgebruik als witgangspunt te nemen voor het nieuwe erfrecht strandden weliswaar, maar het geeft niettemin het belang van dit beperkte recht voor ons rechtssysteem weer. Aan het vruchtgebruik op aandelen werd tot op heden nog geen bijzondere studie gewijd. VAN GAALEN wijdde zijn proefschrift aan het vruchtgebruik in het algemeen ${ }^{2}$ en recentelijk richtte VISSER zich in het bijzonder op de zeggenschapsrechten van de pandhouder en de vruchtgebruiker op aandelen in een besloten vennootschap.

Het onderwerp van deze dissertatie bestrijkt het recht van vruchtgebruik op een aandeel in een kapitaalvennootschap. Centraal staat de vraag wat de rechtspositie is van een vruchtgebruiker op een aandeel. Het onderzoek wordt beperkt tot het Nederlandse recht. De rechtvaardiging hiervoor is gelegen in een voor Europese begrippen uitzonderlijk aspect van het Nederlandse vruchtgebruik. De vruchtgebruiker kan in voorkomende gevallen bevoegd zijn het bezwarde goed to verbrtuken. Daarnasst speelt de inbedding van het recht van vruchtgebruik in het Nedertands arfrecht een belangrijke rol. Bovendien wordt het onderzoek beperkt tot het vruchtgebruik op aandelen in kapitaalvennootschappen. De behandeling van vruchtgebruik op het ruimere begrip effecten brengt niet alleen een afbakenings-probleem ten aanzien van effecten met zich mee, maar doet daarenboven geen recht aan het bijzondere karakter van aandelen. Juist de rechten uit de lidmaatschapsverhouding die het aandeelhouder-

1 H.B. van Riesen, diss. RUL (1923).

2 M.S. van Gatlen, Wrachgebruik (diss. Ansterdan WU), Amsterdam: 2001.

3 K.I. Visser, Zeggenschapsrechten van houders wan een recht wan pand of wruchigebruik op andelen op naam (dis.s. RUG), Uitgave vanwege het Instituut woor Ondernemingsrecht Rijksuniversitent Groningen (48), Deventer: Klower 2004. 
schap belichamen bieden een vruchtbare grond voor de analyse in het kader van het recht van vruchtgebruik. Conclusies die worden getrokken ten aanzien van aandelen zijn niet zonder meer transponeerbaar naar alle effecten. Dat gezegd hebbende zijn de raakvlakken met bepaalde soorten effecten evident.

\subsection{Verantwoording}

De maatschappelijke relevantie van het onderzoek vindt zijn oorsprong voornamelijk in het Nederlandse erfrecht. Het karakter wan het vermogen van natuurlijke personen is in de loop van de vorige eeuw veranderd. Daar waar voorheen roerende zaken en onroerende goederen belangrijke plaatsen innamen in het vermogen van natuurlijke personen, is het accent verschoven naar vermogensrechten. Vermogensrechten in de vorm van tegoeden bij de bank, maar ook vermogensrechten in de zin van aandelen in kapitaalvennootschappen. Bij het overlijden van natuurlijke personen wordt de notaris derhalve frequent geconfronteerd met een nalatenschap waarin zich aandelen bevinden. Het erfrecht kent op zijn beurt een belangrijke rol toe aan het instrument van het vruchtgebruik. Beide constateringen leiden ertoe dat het vruchtgebruik op aandelen een onderdeel vormt van de vermogenspositie van natuurlijke personen en, wanneer deze personen overlijden, voor de erfrechtelijke praktijk:

\subsection{Plan van behandeling}

Het onderzoek begint met een kenschets van de plaats en het karakter van het recht van vruchtgebruik in het Nederlands vermogensrecht. Daarbij zal in het bijzonder aandacht worden besteed aan de verschillende problemen die kunnen ontstaan als gevolg van het feit dat het recht van vruchtgebruik kan worden gevestigd op een verscheidenheid aan soorten goederen. Een gelijksoortige verscheidenheid treft men ook aan bij inventarisatie van versehijningvormen van aandelen. Het daaropvolgende hoofdstuk richt zich op het rechtsgebied dat verantwoordelijk is voor een intensief gebruik van het vruchtgebruiksysteem; het erfrecht. Evenals in het vorige hoofdstuk zal in het bijzonder de aandacht uitgaan naar het aandeel als object van vruchtgebruik. In hoofdstuk 4 bespreek ik de daadwerkelijke wording van een recht van vruchtgebruik op een aandeel. Naast de goederenrechtelijke vereisten van vestiging, worden tevens aanvullende vennootschapsrechtelijke eisen alsook de vennootschapsrechtelijke moeilijkheden onder de loep genomen. Het onderwerp van hoofdstuk 5 betreft de bevoegdheden van de vruchtgebruiker op een aandeel. Daarbij wordt gebruik gemaakt van de kenschets die in hoofdstuk 2 is gemaakt. Na de behandeling van de bevoegdheden van de vruchtgebruiker op een aandeel komt diens relatie met de vennootschap aan bod in hoofdstuk 6. Het hoofdstuk valt uiteen in twee gedeelten. In het eerste gedee]te wordt geanalyseerd welke eigen rechtspositie de vruchtgebruiker toekomt in de vennootschap. In het tweede gedeelte komt een aantal ven- 
nootschapsrechtelijke situaties aan bod waarin de vruchtgebruiker gewild of ongewild betrokken kan raken.

Hoofdstuk 7 brengt het recht van. vruchtgebruik in een breder kader. Nu de eerste hoofdstukken zich richten op de technische vraagstukken van het Nederlands goederen-, erf- en vennootschapsrecht inzake het vruchtgebruik op aandelen, verbreedt hoofdstuk 7 de horizon. Daarnaast is het de bedoeling de problemen die in een eerder stadium zijn gesignaleerd in een ander kader opnieuw te duiden en een plaats in het Nederlandse recht te geven. Tot slot volgen in hoofdstuk 8 de conclusies en aanbevelingen die het dissertatieonderzoek hebben voortgebracht.

Het onderzoek werd afgesloten op 1 februari 2005. 



\section{Hoofdstuk 2}

\section{VRUCHTGEBRUIK}

\subsection{Het recht van wruchtgebruik}

\subsubsection{Plaats in het vermogensrecht}

Het recht van vruchtgebruik is een beperkt genotsrecht met een absoluut karakter. Een beperkt recht is een recht dat is afgeleid uit een meeromvattend 'moederrecht'.' In deze verhouding is de rechthebbende van dit 'moederrecht' de hoofdgerechtigde: De rechthebbende van het afgeleide recht is de beperkt gerechtigde. De wet kent een gesloten systeem van beperkte rechten. ${ }^{2}$ Binnen de beperkte rechten wordt onderscheid gemaakt tussen genots- en zekerheidsrechten. Het recht van vruchtgebruik is een genotsrecht. ${ }^{3}$ Het absolute karakter van het recht van vruchtgebruik doelt op de absolute kenmerken die het kent op grond van het goederenrecht. Absoluut houdt ten eerste in dat het recht tegen een ieder inroepbaar is. ${ }^{4}$ Daarnaast dienen de separatistpositie in faillissement en het kenmerk van 'droit de suite' genoemd te worden. Dat houdt in dat indien het meeromvattende recht wordt vervreemd, het recht van vruchtgebruik op het goed blijft rusten. De vruchtgebruiker behoudt zijn recht ongeacht de persoon van de rechthebbende op het goed.

Vruchtgebruik neemt een uitzonderlijke positie in binnen de beperkte genotsrechten, omdat het gevestigd kan worden op zowel zaken als op vermogensrechten. Dit verklaart zijn positie in Boek 3 (Vermogensrecht) in plaats van Boek 5 (Zakelijke rechten). De overige genotsrechten kunnen alleen worden gevestigd op zaken. Dit leidt er tevens toe dat de omsehrijving van een recht van vruchtgebruik kan verschillen per bezwaard goed. Is een zaak bezwaard met vruchtgebruik, spreekt men van een beperkt zakelijk recht. ${ }^{5}$ De hoofdgerechtigde wordt in dat geval ook wel als blooteigenaar aangeduid. Rust een beperkt recht op een vermogensrecht, dan spreekt men van een absoluut recht of van een recht met een absoluut karakter. ${ }^{6}$ De hoofdgerech-

1 Art. 3:8.

2 Art 3:81 lid 1 eerste zin spreekt van "de in de wel genoemde rechten". Het Nederlandse goederenrecht kent een zogenaamde "mumerus clausus" van beperkte rechter.

3 Voor de verschillen tussen genots- en zeketheidstechten zie Pitlo/Reehuis-Heisterkamp (2001), ns: 590, Asser/Mijnssen-Van Dam-Van Velten 3-11 (2002), nr. 9.

4 PitlorReehuis-Heisterkamp (2001), nr. 21.

5 Asser/Minssen-Van Dam-Van Velten 3-1I (2002), nr. 261; Pitlo/Reehais-Heisterkamp (2001), mr. 678; Snijders-Rank-Bierenschot (2001), nir: 596.

6 Pitlo/Reehuis-Hensterkamp (2001), nr. 678. 
tigde wordt in dit geval niet bloot-eigenaar genoemd ${ }^{7}$, maar men houdt zich aan de meer algemene term hoofdgerechtigde. Aangezien aandelen in kapitaalvennootschappen zowel zaken als vermogens-rechten kunnen zijn, zal in het vervolg de algemene term van hoofdgerechtigde worden gehanteerd.

\subsubsection{Definitie}

Het recht van vruchtgebruik is niet in ons wetboek gedefinieerd, maar wordt ingevuld met behulp van het schetsen van de bevoegdheden van de vrucht-gebruiker. Twee van deze bevoegdheden zijn als constitutief aan te merken. ${ }^{8}$ Artikel 3:201 stelt dat de vruchtgebruiker ten eerste het recht heeft andermans goed te gebruiken. Ten tweede heeft hij, krachtens dat zelfde artikel, het recht om de vruchten van het bezwaarde goed te genieten. Bij het ontbreken van een van beide bevoegdheden kan geen sprake zijn van vruchtgebruik in de zin van artikel 3:201. De bepalingen van titel 8 van Boek 3 zijn in dat geval niet van toepassing.

\subsection{Ontstaan van het vruchtgebruik}

'Beperkte rechten ontstaan door vestiging of verjaring"?

\subsubsection{Vestiging}

\subsubsection{Inleiding}

Vestiging van een beperkt recht kan beschouwd worden als de overdracht van bepaalde rechten uit het moederrecht. ${ }^{16}$ Bijgevolg dienen bij vestiging de voorschriften voor overdracht van het goed, waarop het beperkte recht gevestigd wordt, in acht te worden genomen. ${ }^{1}$ Dit houdt in, dat voor de vestiging van een recht van vruchtgebruik, een geldige titel, beschikkingsbevoegdheid van de vruchtgebruikgever en een "leveting 12 benodigd zijn. Het verkrijgen wan een beperkt recht door middel van vestiging noemt men ook wel 'constitutieve verkrijging'. ${ }^{13}$

Hoewel de rechtsgrond voor het in het leven roepen van het recht van vruchtgebruik kan verschillen, is het belangrijk hier al op te merken dat het de rechthebbende is die het recht in het leven roept ten behoeve van een derde. Dit lijdt enkel uit-

7 Asser/Mijnssen-Van Dam-Van Velten 3-T (2002), nr. 262.

8 T. Melleman Kramenburg, in: "Preadhes Vuchtgebrwik KNB' (1999), p. 15.

9 Art. 3:202.

10 Vergelijk T.M., Parl. Gesch. Boek 3, p. 404.

11 Art. 3:98 jo 3:84.

12 Strikt genomen is levering hier niet de juist term. Het gebruik karl verwarring bij de lezer stichten. In $54.2 .2 \mathrm{ga}$ ik verder in op deze terminologische problematiek.

13 Asser/Mijnssen-De Haan 3-I (2001), nr. 195. 
zondering in het geval het recht van wruchtgebruik door de rechthebbende ten behoeve van zichzelf wordt voorbehouden. Deze constructie wordt in $\$ 2.2$ besproken. Vestiging is de meest gangbare ontstaanswijze voor het recht van vruchtgebruik.

\subsubsection{Titel}

Voor vestiging van een recht van vruchtgebruik is, zoals hierboven werd vermeld, een geldige titel vereist: Onder titel moet worden verstaan de rechtsverhouding die aan de vestiging ten grondslag ligt en deze rechtvaardigt ${ }^{14}$ Nederland hanteert bij de overdracht het causale stelsel hetgeen inhoudt dat een ongeldige titel geen overdracht en in dit geval geen vestiging kan bewerkstelligen. ${ }^{\text {is }}$ Onder het oude erfrecht vormde het testament en meer in het bijzonder het legaat de meest voorkomende titel voor vestiging van vruchtgebruik. ${ }^{16}$ Zulks hing naw samen met het vruchtgebruik dat als belangrijke testamentaire voorziening voor de langstlevende werd ingezet. Inmiddels is het nieuwe erfrecht van kracht geworden en is de noodzaak om door niddel van een testament zorg te dragen voor de langstlevende grotendeels weggenomen. De bedoellde zorg is namelijk een van de hoofddoelen van het nieuwe ab intestaat erfrecht. "Het recht van vruchtgebruik als 'zorginstrument' is met de invoering van het nieuwe erfrecht dwingend verankerd in onder andere de artikelen $4: 29$ en $4: 30.18$

In enkele gevallen kan de titel van de vestiging ook uit de wet voortvloeien. ${ }^{\text {I }}$ Dit is het geval bij de 'tijdelijke eigendomsvormen' van artikel $3: 85^{20}$ en de verwante conversie van artikel $4: 136$ lid 1.21

\subsubsection{Beschikkingsbevoegdheid}

Degene die het recht van vruchtgebruik vestigt dient beschikkingsbevoegd te zijn. Artikel 3:81 lid 1 bepaalt dat wie een zelfstandig en overdraagbaar recht toekomt, binnen de grenzen van dit recht, beperkte rechten kan vestigen. Voor wat betreft de overdraagbaarheid zij verwezen naar artikel $3: 83$. De wet, de aard van het goed of

14 Asser/Mijnssen-De Haan 3-1 (2001), nr. 239; Pitho/Reehwis-Heisterkamp (2001), nr. 113.

15 Asser/Mijnssen-De Haan 3-1 (2001), nr. 238; Pito/Reehtris-Heisterkamp (2001), ni. 114; SnijdorsRank-Berenschot (2001), nr. 318 .

16. Asser/Mijnssen-Van Dam-Van Velten 3-Il (2002), nr. 266; Pitlo/Reehuig-Heisterkamp (2001), n: 683.

17 Zile voor de bespreking \$ 3.2 .1 .

18. Zie voor de bespreking van deze rechten $\$ 3.2 .3$.

19 In een bijzonder geval ontstat het recht van vruchtgebrukk op een goed van rechtswege. Zulks is het geval bij substitutie. Zie voor de bespreking $\$_{2} 6$.

20 MELEאS oordeelde dat tijdelijk eigendom in het niewwe BW geen plats had en geconverteerd diende te worden naai een vruchtgebruik. Zie hienover E.B. Rank-Berenschot, in: "Wan Beheering" (1998), p. $\| 49$ en verder. Artikel 3.85 lid 1 bepalt dat een verbintenis tot overduach wan een goed woor een bepaalde tajd, moet worden aangemerkt als verbintenis tot het vestigen van ean recht wan

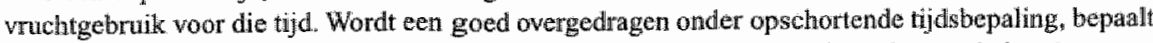
lid 2 van het artikel dat zulks moet worden angemerkt als een owerdracht onder woorbehoud wan een recht van vruchtgebruik voor de bepaalde tijd.

21 Zie voor de bespreking $3,4,3$. 
afspraken tussen partijen kunnen zich tegen de overdraagbaarheid en aldus tegen de vestiging van beperkte rechten verzetten. ${ }^{22}$

Een beoogd vruchtgebruiker op een roerende zaak, wiens recht door een beschikkingsonbevoegde wordt gevestigd, staat veelal in de kou wat derdenbescherming betreft. Voor de heling van deze beschikkingsonbevoegdheid is immers vereist dat de vestiging, op voet van artikel 3:86, anders dan om niet geschiedde. Zoals hierboven aangestipt, wordt het vruchtgebruik veelal op grond van legaat (of in het nieuw erf-

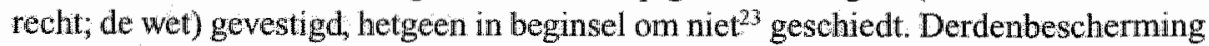
zal reeds om die reden de aspirant vrucht-gebruiker geen soelaas kunnen bieden.

In het kader van het vruchtgebruik op een onroerende is de derdenbescherming om een andere reden prominent nu bij de vestiging van het vruchtgebruik een notaris is betrokken en deze de beschikkingsbevoegdheid van de hoofdgerechtigde zal toetsen. Reeds uit dien hoofde wordt de beoogd vruchtgebruiker rechtsbescherming geboden.

\subsubsection{Levering: vestiging}

Als gevolg van de schakelbepaling van artikel $3: 98$ is de vestigingswijze van het recht van vruchtgebruik op een goed onlosmakelijk verbonden met de aard van het te bezwaren goed. De vestiging van het beperkte recht volgt nauwgezet de levering van het goed. Een belangrijk verschil vindt men evenwel in de juridische betekenis van de levering. Voor het vestigen van een beperkt recht is de leveringshandeling van het goed tegelijkertijd de vestigingshandeling van het beperkte reclat. ${ }^{24}$ In het geval van vestiging van vruchtgebruik op een onroerende zaak is een notariële akte vereist, die wervolgens ingeschreven moet worden. ${ }^{25} \mathrm{Bij}$ roerende zaken is doorgaans bezitsverschaffing de vereiste vorm van levering en derhalve van vestiging. ${ }^{26}$

Met betrekking tot dit laatste is een nadere algemene beschouwing op zijn plaats, aangezien enige controverse ten aanzien van de vestigingshandeling van het recht van vruchtgebruik aan het licht komt. Inmiddels is opgemerkt dat de vereisten voor vestiging van een recht van vruchtgebruik rechtstreeks worden ontleend aan de vereisten van overdracht van thet desbetreffende goed. De controverse richt zich in deze regeling op het leveringsvereiste van een roerende zaak. Artikel 3:90 leert ons dat voor roerende zaken, niet-registergoederen bezitsverschaffing in beginsel de voorschreven vorm van levering is. Centraal staat de vraag: wát moet geleverd worden, de zaak $^{27}$ of het recht van vruchtgebruik?

22 Een woorbeeld van een wettelijke beperking is te winderi in arrikel $3: 226$ lid 3 (gebruik en bowoning).

23 Tenzij er sprake is van inbreng door de erfgenaam of legataris.

24 Asser/Mijnssen-Van Dam-Van Velten 3-II (2002), nr. 265. Vergelijk voor een uitgebreidere bespreking wan de samenhangende termen levering, leveringshandeling, vestiging en vestigings-handeling $\$ 32.2$.

25 Art. 398 jo $3: 89$

26 Art. $3: 90$ jo $3: 93$.

27 Daar het hierna te behandelen probleem zich enkel manifesteert bij roerende zaken, niet-registergoederen zal in het wervolgen gesproken worden van een zaak 
Artikel 3:90 legt bij de levering van een roerende zaak de nadruk op het corporele aspect van de levering te weten de bezitsverschaffing. BERENSCHOT signaleerde reeds het probleem dat wanneer het bezwaarde goed een roerende zaak betreft, de vruchtgebruiker moeilijk het bezit van de bezwaarde zaak verschaft kan worden, aangezien de vruchtgebruiker slechts houder kan zijn van de betreffende zaak. ${ }^{28} \mathrm{Be}$ zwaarlijk kan dus worden gesproken van bezitsverschaffing wan de zaak in het kader van de vestiging van het beperkte recht. BERENSCHOT staat een wijziging van artikel $3: 202$ voor in de zin van artikel 3:236. Aldus zou kunnen worden bepaald dat vestiging van een recht van vruchtgebruik geschiedt door de zaak 'in de macht van de vruchtgebruiker te brengen'. ${ }^{29}$ Daartegenover staat de visie van NIESKENS-ISPHORDING die geen probleem ziet en, citerend uit de Parlementaire Geschiedenis, concludeert dat niét het bezit van de bezwaarde zaak maar het bezit van het recht van vruchtgebruik verschaft moet worden ${ }^{30} \mathrm{Zulks}$ is overigens goed te plaatsen voor wat betreft de overige leveringsvormen die als vestigingshandeling zijn voorgeschreven. Zo zal duidelijk zijn dat bij de levering door middel van een notariële akte niet de overdracht van het onroerende goed, maar de vestiging wan het recht van vruchtgebruik onderwerp van de zakelijke overeenkomst is, belichaamd in de akte. Hoewel deze redenering naar mijn smaak elegant oogt ontbreekt een voor de vruchtgebruiker essentieel element. Hiermee wordt inmers nagelaten te verduidelijken hoe de laatste in de gelegenheid wordt gesteld het goed ook daadwerkelijk te gebruiken ${ }^{31}$ Bovendien blijft tevens onopgehelderd wat onder 'bezitsverschaffing van het recht van vruchtgebruik' moet worden verstaan. Ook de lezing van NiESKENS-ISPHORDING leidt derhalve evenals in de visie van BERENSCHOT c.s. - tot een noodzakelijke wetswijziging. De vruchtgebruiker dient in het kader van de totstandkoming van het recht van vruchtgebruik alsmede voor uitoefening daarvan op enig moment de feitelijke macht over de zaak te verkrijgen. In navolging van BERENSCHOr en VAN GAALEN komt een subtiële wetswijziging mij als juist voor ${ }^{32}$ Zowel het eerder genoemde artikel 3:236 als artikel 3:91 maken een feitelijke machtsverschaffing zonder bezitsverschaffing reeds mogelijk. Het interversieverbod van artikel 3:111 behoedt de rechthebbende voor een al te bezitterige vruchtgebruiker.

Niettegenstaande het zojuist genoemde interversieverbod blijft de bescherming van de rechthebbende in dit geval uitermate summier. De vruchtgebruiker van een roerende zaak, niet-register goed, is uit de aard van zijn beperkte recht en naar de verkeersopvatting ${ }^{33}$ in niets te onderscheiden van de bezitter/rechthebbende. Het nor-

28 E.B. Berenschot, WPNR 5730 (1985), p. 170. Alsmede instemmend W.M. Klejin, "Vruchtgebritk. Mon.NBW B-10' (1990), p. 13; M.S. van Gaalen, diss. VU (2001), nr. 188.

29 Berenschot, $a . w$, p. 170. VAN GAALEN onderschrijft het woorstel tot een dergelijke wijziging. Van Gaälen, diss, nt. 188.

30 B.W.M. Nieskens-lsphording, WPNR 6081 (1993), p. 136. Kennelijk met instemming: Asser/Mijnssen-Van Dam-Van Velten 3-II (2002), m. 265; Pitlo/Reehuis-Heisterkamp (2001), nr. 296.

31 Zie ook Van Gaalen, diss., nur. 188 in fine.

32 Vergetijk hiervoor het zojuist besproken voorstel wan BERENSCHOT.

33 Art. 3:108. 
male gebruik waartoe de vruchingebruiker gerechtigd is ${ }^{34}$ kan veelal inmers naar verkeersopvatting als het verrichten van bezitsdaden worden aangemerkt, temeer daar de verkeersopvatting zich richt op uiterlijke feiten. ${ }^{35}$ Sterker nog, een rechthebbende zal slechts met veel moeite kunnen aantonen dat hij juridisch gezien deze positie bekleedt, nu hij zich niet kan bedienen van de processuele functie ${ }^{36}$ van (onmiddellijk) bezit. Afgezien van een eventueel te ontspinnen onderlinge bezitsstrijd, maakt een mogelijke - uiteraard onbevoegd verrichte - overdracht door de vruchtgebruiker de positie van de hoofdgerechtigde uiterst precair. ${ }^{37}$

Daar, zoals gezegd, het object van vruchtgebruik onlosmakelijk verbonden is met de vestigingsvereisten, zal de behandeling van de vestiging van een recht van wruchtgebruik op een aandeel in een kapitaalvennootschap in een afzonderlijk hoofdstuk plaatswinden. De versehillen in aandelensoorten en de te bespreken vennootschapsrechtelijke implicaties droegen tevens bij tot het maken van deze keuze. Voor bespreking verwijs ik derhalve naar hoofdstuk 4 .

\subsubsection{Overdracht onder voorbehoud van vruchtgebruik}

Naast de reguliere vestiging van een recht van vruchtgebruik kent de wet tevens een bijzondere vorm van vestiging. Een rechthebbende is namelijk gerechtigd zich bij overdracht het recht van vruchtgebruik voor te behouden. De wettekst luidt:

'Hij kan ook zijn recht onder voorbehoud van een zodanig [beperkt] recht overdragen $(. . .)^{38}$

Onder het oude recht bestond discussie over de dogmatische invulling van de overdracht onder voorbehoud wan een beperkt recht. BREGSTEIN concludeerde in 1956 , naar aanleiding van een rechtsvraag in het WPNR, dat het voorbehoudlen van een beperkt recht niets anders inhield dan de overdracht van het goed met daaropvolgend de vestiging van het beperkte recht ten behoeve van de vervreemder. ${ }^{39}$ De stelling werd terstond ter discussie gesteld en andere auteurs, waaronder later preadviseur LUBBERS in zijn bespreking van het vruchtgebruik ${ }^{40}$, waren van mening dat het vruchtgebruik door de vervreemder zelf wordt gevestigd en slechts het bezwaarde

34 Ant. 3207 lid 1 . Zie voor de bespreking $\$ 2.42$.

35 Zik voor een behandeling van de verkersopvatting in thet kader van bezit E B. Rank-Berenschot, "Bezit. MonNBW B-7" (2001), nit. 16.

36 A.C. var Schaick, "Rechtsgevolgen en functies wan bezit en houderschap. Mon NBW A-14" (2003), Hr: 61 ; Pitlor Reehuis-Heisterkanp (2001), nr. 390

37 Voor een bespreking wan onbevoegd beschikken door de vruchtgebruiker verwijs ik naar 82.6 .5 van dit hoofdstuk.

38 Art. 3.8\ lia 1 , tweede zin.

39 M.H. Bregstem, WPNR 4335 (1954), p. 91.

40 In navolging wan H.A. Drielsma, WPNR 4419 (1955), p. 467; A.G. Lubbers, "Preadwies Wruchtgebruik KNB: $(1959)$, p. 62. 
eigendom wordt overgedragen. Het volle eigendom heeft in deze visie nooit tot het vermogen van de verkrijger behoord. ${ }^{41}$ In 1979 kreeg de Hoge Raad de mogelijkheid zich over de kwestie uit te spreken. Het arrest betrof weliswaar in hoofdzaak een belastingtechnische vraag, maar de Hoge Raad wijdde in zijn uitspraak een alinea aan voornoemde kwestie. ${ }^{42}$ De Raad overwoog:

${ }^{\prime}($... $)$ dat indien - gelijk te dezen naar "s Hofs vaststelling het geval is - een overeenkomst van koop en verkoop het beding inhoudt dat de verkoper zich bij de levering van het verkochte een recht van vruchtgebruik daarop zal voorbehouden, zodat dienovereenkomstig slechts de blote eigendiom van het verkochte wordt geleverd, niet - gelijk het Hof doet - kan worden gezegd dat het voorwerp van die overeenkomst van koop en verkoop de volle eigendom van het verkochte is; $(\ldots)^{343}$

Hoewell na de uitspraak korte tijd verwarring bestond over het exacte gewicht van het arrest ${ }^{44}$, maakte de opname van de regeling in het nieuwe Burgerlijk Wetboek duidelijk dat de wetgever de visie van LuBBERS c.s. onderschreef. ${ }^{45}$ In 1999 gaf de Hoge Raad een ondubbelzinnig antwoord op de vragen rond het voorbehouden beperkte recht in het arrest. Potharst/Serée. ${ }^{46}$

Hierin oordeelde hij:

'Ingeval van eigendomsovergang onder voorbehoud van pandrecht, wordt een recht verkregen dat van meet af aan met het pandrecht is belast. Dat pandrecht is immers bij de oorspronkelijke rechthebbende blijven berusten zodat de verkrijger geen pandrecht heeft kunnen vestigen dat als eerder gevestigd zou moeten worden aangemerkt. ${ }^{47}$

Toch kan niet worden volgehouden dat de constructie onomstreden is ${ }^{48}$ Door tegenstanders opgeworpen bezwaren, zoals de onmogelijkheid van het bestaan van een

41 Zie voor een gedetailleerd overzicht wan de discussie A.J.H. Pleysier, WPNR 5509 (1980) en WPNR 5510 (1980). Alsnede RANK-BERENSCHor in haar proefschrift (E.B. Rank-Berenschot, diss. RUL (1992), p. 107). PLEYSIER bespreekt de rechtsvraag tevens vanuit een rechtshistorisch perspectief.

42 FR 7 februari 1979, NJ 1979, 551 m.nt. WMK (Voorbehoud wruchtgebruik).

43 R.o. 7 op p. 1860.

44 Zie hierover A.J.H. Pleysier, WPNR 5530 (1980). Het hoofdzakelijk fiscale katakter wan het arrest alsmede de gekozen bewoordingen - de obligatoire termen "koop" en "verkoop", in plaats van de goederenrechtelijke term 'overdracht' - waren debet aan de verwarring.

45 MvT, Parl. Gesch. Boek 3 (inv 3, 5 en 6), p. 1195.

46 HR 4 december 1998, NJ 1999, 549 m.nt. WMK (Potharstserrée).

47 'Potharst/Serrée'; r.0. 3.6.4.

48 KRAAN betitelt de regeling als "dogmatisch onjuist", C.A. Kraan, in: "Preadvies Vruchigebruik KNB" (1999), p. 82. 
beperkt recht en een moederrecht in éen vermogen ${ }^{49}$, leiden tot de conclusie dat het voorbehouden vruchtgebruik zich slecht verdraagt met ons goederen-rechteiijk systeem. ${ }^{50}$ Overigens is deze dogmatisch niet altijd waarneembaar in de (notariële) praktijk. In het kader van een recht van vruchtgebruik op een onroerende zaak kan de overdracht van de zaak en de vestiging van het vruchtgebruik in een notariële akte worden neergelegd. ${ }^{51}$

De discussie tond het voorbehouden beperkte recht illustreert naar mijn mening evenwel de juistheid van de zienswijze waarin de eigendom wordt begrepen als een opeenstapeling van bevoegdheden. ${ }^{52}$ Bepaalde bevoegdheden kunnen op goederenrechtelijke wijze worden 'overgedragen' door vestiging van een beperkt recht. Andere bevoegdheden kunnen als rechten door middel van een eenvoudige overdracht worden overgedragen. ${ }^{53}$

\subsubsection{Verjaring}

De acquisitieve verjaring vindt haar regeling in artikel 3:99 BW. Voor wat betreft rechten op roerende zaken/niet-registergoederen en rechten aan toonder of order ontstaat vruchtgebruik door verjaring voor degene die het bezit te goeder trouw heeft verkregen door het onafgebroken bezit gedurende drie jaren. Voor alle andere goederen geldt een acquisitieve verjaringstermijn van tien jaar.

Verjaring speelt met name een rol wanneer er gebreken kleven aan de vestiging, zoals bij het ontbreken van een geldige titel of wanneer niet of niet volledig is voldaan aan de formele eisen die aan de vestiging zijn gesteld. De belangrijkste drempel voor verkrijgende verjaring is de goede trouw van de bezitter. Het artikel 3:118 lid 1 volgt dat de bezitter te goeder trouw is als hij zich redelijkerwijze als vruchtgebruiker mocht beschouwen. Onopgemerkte gebreken in de notariële akte of andere vestigingsformaliteiten zijn dan de meest voorkomende gevallen waarin een bezitter te goeder trouw kan aannemen vruchtgebruiker te zijn. ${ }^{54}$

49 L.G.F. van Dooren, WPPR $5262(1974)$, p. 298.

50 Aldus Pitlo/Reohuis-Heisterkanm (2001), nr. 597.

51 Vergelijk Handbeek Nieuw Erfiecht (2002), p. 85 alsook Pitlo/Reehuis-Heistarkamp (2001), 597.

52 Hetgeen gestafaf wordt door de Toelichting Meijers in het kader wan de vestiging. Zie noot 10 (supra). Deze mening deel ik in leder gevali met BERenschot. D. B. Berenschot, WPNR 5730 (1985), p. $|7|$.

53 Een en ander geldt natumlijk indien de bevoegdheid een vermogensrecht is in de zin van art. 3:6, overdtaghbar ex art. 3.81 hid I en voor het overige aan de vereisten voor overdracht (art. $3: 84$ ) is voldann.

54 T.I. Mellema-Kranenburg, in: 'Preadves Wuchtgebruik KNB' (1999), p. 18. 


\subsection{Duur van het vruchtgebruik}

\subsection{Het leven wan de wruchigebruiker}

Naast de in $\$ 1.2$ genoemde constitutieve kemmerken is de duur van het recht van vruchtgebruik een wan de meest kenmerkende eigenschappen. De dunr wordt begrensd door het leven van de vruchtgebruiker en is daar dientengevolge onlosmakelijk mee verbonden. ${ }^{55}$ Indien de eerste vruchtgebruiker zijn vruchtgebruik vervreemdt of bezwaart blift het bestaan van het vruchtgebruik steeds verbonden aan het leven van de eerste vruchtgebruiker. ${ }^{56}$

Artikel 3:203 lid 2 bepaalt dat vruchtgebruik ook gevestigd kan worden ten behoeve van twee of meer personen. In thet kader van deze regeling kunnen twee constructies worden onderscheiden:

a) gezamenlijk vruchtgebruik

b) opvolgend vruchtgebruik

\subsubsection{Gezamenlijk wruchtgebruik}

Van gezamenlijk vruchtgebruik is sprake indien ten behoeve van twee of meer personen een recht van vruchtgebruik gevestigd wordt. Een woorbeeld daarvan is de overdracht van de woning aan de kinderen door de ouders onder voorbehoud van een recht van vruchtgebruik ten behoeve van beide laatstgenoemden. Zolang beide ouders in leven zijn komt het vruchtgebruik hen beide toe en wamneer een van hen overlijdt wordt de langstlevende ouder gerechtigd voor het hele vruchtgebruik:

(...) Vruchtgebruik ten behoeve van twee of meer personen wast bij het einde van het recht van een hunner bij dat van de anderen aan, $(\ldots))^{.57}$

Uiteraard kan bij vestiging worden bepaald dat bij het sterven van de een de ander s]echts het vruchtgebruik over de helft van het goed heeft. Het vruchtgebruik van de ander gaat dan bij diens overlijen teniet en het eigendom van de hoofo-gerechtigde wast in evenredigheid aan. ${ }^{58}$ De hoofdgerechtigde verkrijgt dan het recht van vruchtgebruik. Er vindt vermenging plaats ${ }^{59}$ waardoor het eigendom over het goed voor de hoofdgerechtigde wer "heel" wordt en het vruchtgebruik tenietgaat. ${ }^{60}$

55 Art. 3,203 lid 2 eerste zin: "Vruchtgebruik kan niet worden gevestigd woor langer dan het leven van de vruchtgebruiker."

56 Art. 2223 .

57 Art. $3: 203$ lid 2 .

58 De geciteende regeling uit art. $3: 203$ lid 2 wordt besloten met ' (...), tenzill anders is bepaald."

59 Artikel $5: 15$ jo $5: 14$ en $3: 4$.

60) Artikel 3.81 lid 2 sub e. 


\subsubsection{Opvolgend vruchtgebruik}

In het geval van een opvolgend vruchtgebruik zijn er eveneens verschillende vruchtgebruikers, echter niet tegelijkertijd maar bij opvolging. A vestigt een wruchtgebruik bij opvolging ten behoeve van $B$ en $C$. C verkrijgt het vruchtgebruik op een door $A$ vastgesteld tijdstip. Een voor de hand liggend scenario is dat $C$ het recht van vruchtgebruik verkrijgt na overlijden van $B$. Dit betekent niét dat het vruchtgebruik van $B$ over gaat op $C$, maar dat $C$ verkrijgt van hoofdgerechtigde $A$. Voor deze constructie is wél vereist dat de vruchtgebruikers $\mathrm{B}$ en $\mathrm{C}$ ten tijde van de vestiging bestaan. ${ }^{61}$

\subsubsection{De rechtspersoon als vruchtgebruiker}

Een rechtspersoon is voor wat het vermogensrecht betreft gelijkgesteld met een natuurlijk persoon en hij kan derhalve het recht van vruchtgebruik verkrijgen. ${ }^{62}$ Het leven van de natuurlijke persoon is eindig. De rechtspersoon is in beginsel een eeuwig leven beschoren. ${ }^{63}$ Aangezien dit gegeven en het uitgangspunt van de duur van vruchtgebruik er toe leiden dat het vruchtgebruik van een rechtspersoon in beginsel onbegrensd is, heeft de wetgever hier een maximumtermijn aan verbonden. Verkrijgt een rechtspersoon het recht van vruchtgebruik, dan is de duur van dit vruchtgebruik beperkt tot dertig jaar. ${ }^{64}$ Ondanks deze begrenzing is het instellen van het recht van vruchtgebruik ten behoeve van een rechtspersoon een interessant instrument. Zo kan het bijvoorbeeld een oplossing bieden indien de werkelijk beoogde vruchtgebruiker - bijvoorbeeld een (achter-) kleinkind - nog niet geboren is en derhalve niet in een opvolgend vruchtgebruik kan worden opgenomen. Een stichting die het vruchtgebruik verkrijgt ten einde dit in de tussentijd te beheren is een elegante oplossing. ${ }^{65}$

\subsubsection{Einde van het wruchtgebruik}

Artikel 3:81 lid 2 geeft de gevallen waarin een beperkt recht tenietgaat. Achtereenvolgens zijn dit; tenietgaan van het bezwaarde goed (sub a), tijdsverloop of ontbindende voorwaarde (sub b), afstand (sub c), opzegging (sub d) en ten slotte ver-

61 Voor de verhouding B - C en de precieze goederenrechteijke gang van zaken verwigs ik naar W.M. Kleijn, "Wrachgebruik. Mon.WBW B-10" (1990), nr. 2 en T.J. Mellemamranenburg, in: Preadvies Fuchtgebrik KNB' (1999) p. 21.

62 Art. 2:5.

63 Art. 2:17, slechts ontbinding luidt het ultieme einde van de rechtspersoon in (art. $2: 19$ ).

64 Art. 3:203 lid 3 .

65 W. Burgerhart, Silching of Venewiging 2002/1, p. 16 en verder; W.M. Kleinn, "V"uchgebruik. Mon NBWF B-10' (1990), nr. 2; Asset/Perrick 6A (2002), nr. 33; Handboek Nieuw Erfrecht (2002), p. 211 ; Klatassen-Lujiten-Meijer (2002), mr. 304. Voor deze erfrechtelijke verkrijging door een rechtspersoon is in het nieuwe erfrecht een bepaling opgenomen (art. $4: 135$ ) hetwelk feitelijk een verhuizing betreft van het oude art. 2:288. Zie Kamerstukken II $1999-2000,27245$, nr. 3, p. 4. 
menging (sub e). Voorts geven de artikelen $3: 211$ en $3: 224$ bijzondere regelingen betreffende vermenging en afstand van het recht van vruchtgebruik.

\subsection{Rechten van de vruchtgebruiker}

Zoals gezegd word het vruchtgebruik gevormd door de bevoegdheden van de vruchtgebruiker. ${ }^{66}$ Het bestatan van deze bevoegdheden en het uitoefenen ervan door de vruchtgebruiker zijn van verschillende omstandigheden afhankelijk, zoals de aard en de bestemming van het in vruchtgebruik gegeven goed. De volgende bevoegdheden van de wruchtgebruiker zullen achtereenvolgens worden besproken:

a) de bevoegdheid van de vruchtgebruiker om de vruchten te genieten $(\$ 4.1)$;

b) de bevoegdheid de aan het vruchtgebruik onderworpen goederen te gebruiken $(84.2)$

c) de beheersbevoegdheid van de vruchtgebruiker $(\$ 4.3)$;

d) de beschikkingsbevoegdheid van de vruchtgebruiker $(\$ 4.4)$.

\subsubsection{Recht op de vruchten}

\subsubsection{Inleiding}

Een prominent recht dat de vruchtgebruiker ter beschikking staat is het recht op de vruchten van het goed. Artikel 3:216 kent de vruchtgebruiker alle vruchten toe die tijdens het vruchtgebruik afgescheiden of opeisbaar worden.

Vruchten worden onderscheiden in natuurlijke vruchten en burgerlijke vruchten. ${ }^{67}$ De vraag wat precies vruchten zijn wordt door de wet niet beantwoord. In plaats daarvan verwijzen de leden 1 en 2 van artikel 3:9 naar de verkeers-opvatting. of een bepaalde zaak of een bepaald recht ${ }^{68}$ respectievelijk een natuurlijk vrucht is of een burgerlijke vrucht zal op grond van de genoemde verkeersopvatting moeten worden uitgemaakt. Hierbij dient aangetekend te worden dat de wetgever er kennelijk vanuit

66 Zie $\$ 2.1 .2$

67 Art. 3:9 lid 1 en 2.

68 VAN GAALEN spreekt in dit kader in zijn proefschrift wan wermogensrechten (Van Gaalen, diss., nr. 226 en 229). De kennelijk getrokken conclusie is dat een recht dat geen vermogensrecht is, geen vrucht kan zijn. Afgezien wan het feit dat de conclusie niet onderbouwd wordt, waag ilk te betwijfelen of een dergelijke beperking van potentielle vruchten strookt met de wet. Het recht om een vergadering bij te wonen valt moeilijk onder de vermogensrechtbeschrijving van art. 3:6 te platsen. Toch walt niet in te zien dat een dergelijk recht geen vrucht van een aandeel kán zijin. Sterker nog, de toekenning wan het genoemde recht aan de vruchtgebruker ex art. 2:88/197 lid 4 lijkt het tegenavergestelde te impliceren. Zie voor een verdere bespreking van de vennootschapstechtelijke rechten hoofdstuk 6 . 
gat dat niet alle voordelen vruchten behoeven te zijn in de zin van artikel $3: 9.69$ MuNSsev definieent wruchten als 'opbrengsten die zaken en rechen min of meer regelmatig opleveren". "Daarnaast wordt in de literatuur gebruik gemaakt wan klassieke voorbeelden. Nauurlijke vruchten zijn de appels van de boom en het kalf van de koe. "t Rechtspraak scherpt de imulling met behulp van de verkeersopvating nog wat aan en oondeelt dat onder onstandig-heden een kuiken géen vrucht is van de kip. ${ }^{2}$ De behandeling van burgerlijke vruchten volgen een zelfde stramien. Als klassieke voorbeelden worden genoemd de humpenningen vam onroerend goed en de rente op een vordering. ${ }^{73}$ Aanscherping van de burgerlijke wruchten vindt met name plaats daar waar het betrelt de vruchten wan aandelen. Een dividenduitkering is de burgerlijke vrucht van en aandeel in een kapitaalvennootschap, een claimbewijs is dat daarentegen niet ${ }^{74}$ Hoewel literatuur en rechtspraak handreikingen kumen geven voor de vraag wat volgens de verkeersopvatting een vrucht van een goed is, of hever gezegd op dat bepaalde noment was, is daarmee een eenduidig antwoord niet gegeven. ${ }^{75}$

\subsubsection{Verkeersopvatting}

De verwijzing naar de verkeersopvatting is enerzijds in artikel $3: 9^{76}$ opgenomen vanwege de flexibiliteit die het in zich draget. ${ }^{7}$ De verkeersopvatting is een open

69 Dit volgt wit lid 3 wan artike $3: 213$ waarin staat dat ook am het vruchigebruik onderworpen zijn "(...) voordelen alie een goed tijdens het vruchtgebruk oplewert en die geen vruchten zijn." VAN

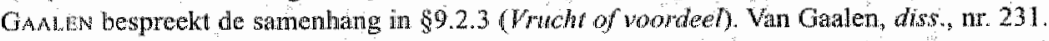

70 Asser/Mighssen-De Haan 3-1 (2001), nr. 74. Opvallend is dat, ten opzichte van de vorige druk (Asser Mijnssen-De Han (1992), na: 88), in deze latste dnuk de zinsnede met behoud van hun substantie' is verdwenen. De definitie met inbegrip van voorganande zinsnede werd kennelijk reeds door Brakutus (Asser/Beekluis 3-1 (1957), p. 51 ) geberigd. Zie Van Gaallen, diss, nir. 226 (noot 3).

71. Pitlo/Reehuis-Heisterkamp (2001), nr. 686, Snijders-Rank-Berenschot (2001), nI. 43.

72. De Hoge Raad ontkwam niet aan de juridisering van de kip-of-eh kwestie in HR 24 maart $1995, \mathrm{NJ}$ 1996, 158 m.nt. WMK (Hollander 's/Coöperwieve Raiffeisenbank). Voor een bespreking zie Asser Mijnssen-De Haan $3-1$ (2001), nr. 75, alsmede uigebreider H.A.G. Fikkers, NJB 1996/8, p. 274 en verder.

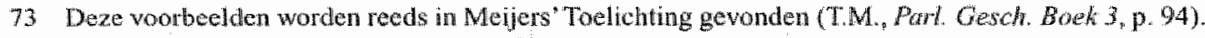
Pitho/Reduis-Heisterkamp (2001), nr. 686; Snijders-Rank-Berenschot (2001), wr. 43 .

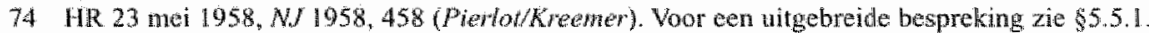

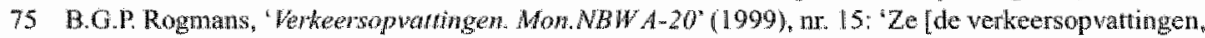
$[B C B]$ zing zelden sendinidig."

76 De verwijzing nad de verkeersopwatting komt verder voor in de arti $3: 4,3: 108$ en $3: 254$, alsnede ith ant: $5: 1.4$ thtin 16 .

77 Het argument is ontleend aan de 'verkeersopvatting' opgenomen in art. 3:4. VAN DER GRUMTEN leverm de in een vroeg stadium kntick op de ketze voor verkeersopvatting als critenum en stelde voor het criterium te schrappen (WPNR 5153 (1971), p. 520). In het Mondeling Overleg stelde de wetgever, als anwoord op de kritick wan VAN DER GRINTEN, dat de term 'verkeersopwatting' de kwalitein heeffi om 'nat do tjid mee te bewegen' en her niet opnemen van deze matstaf een stap terig zou betekenen (MO PaH Gesch. Boek 3, p. 77). ROGWhNS geeft een kort overzicht van deze discussio (Rogmans, $a$ w. nar. 20), Overigens is de verkeersopvatting in het kader van art. $3: 4$ veel mitgebreider besproken en onderzocht. Zij vorm dan ook een rijke bron aan opvattingen over verkeersopvattingen. Kortheidshalve zij hier verwezen naar het proefsehrift van Whore; JE. Wichers, diss: RUG (2002). 
norm. ${ }^{75}$ De rechter heeft daarmee de vrijheid te toetsen of in afzonderlijke gevallen (...) een bepaalde zaak al dan niet behoort tot de soort die object van wetgeving was." ROGMANS neemt aan dat de rol van de "goederenrechtelijke werkeers-opvatting" een definiërende of begripsbepalende is. ${ }^{80}$ Deze verkeersopvatting betreft een feitelijke en 'technische' vraag. ${ }^{\& 1}$ Dit in tegenstelling tot de ruimere verbintenisrechtelijke versie welke veeleer een startpunt vormt en vraagt naar een juridische normering van een feitelijke situatie. ${ }^{82}$ Anderzijds wordt in de verkeersopvatting een objectiverende maatstaf gezocht. ${ }^{83}$ Niet partijen duiden de inhoud van het begrip, maar de objectievere verkeersopvattingen. ${ }^{84}$ In antwoord op de vrang: wiens opvatting(en), wordt algemeen aangenomen dat de verkeers-opvatting moeten worden gezocht in het zakelijk oordeel dat in een beperkte kring van het economische leven leeft. ${ }^{35}$ Meer in het bijzonder de kring van personen die regelmatig betrokken zijin bij de feitelijke en technische vraag welke beantwoord dient te worden. ${ }^{86}$ RosseL meent dat in een dergelijk geval de rechter het beste (mede) kan afgaan op een "deskundigenbericht" te dier zake. ${ }^{87}$

Het feit dat de verkeersopvatting om haar flexibiliteit is gekozen brengt echter aok een bepaalde onzekerheid met zich. VAN SCHAICK gaat zelfs zover te stellen dat het de rechtszekerheid ondergraaft. ${ }^{88}$ De mate van onzekerheid kan mijns inziens desondanks niet opwegen tegen de (behoefte aan) flexibiliteit die de verkeersopvatting als criterium het goederenrecht, en meer in het bijzonder de rechter, biedt. Wat op een bepaald moment in een bepaald geval als vrucht van een vermogensrecht wordt

78 Vergelijk Wichers, die aangeeft de term 'open norm' te prefereren bovem "wage nom' en de onherroepelijk daarbij rijzende typeringen van "weinig bepaabaan", "moenlijk grijpbaar' en "vakg". Wichers, diss, p: 35. Anders J.E. Feserur, MNPR 6472 (2002), p. 31.

79 Rogmans, a.w, nr. 2. RocmANs ontleent het cital op zijn bourt weer adir de noot van Wachre: bij HR 16 maart $1979, \mathrm{NJ} 1980,600$.

80. Rogntans, a.m. n. 2. Rossel makkte rond die tijd- de eerste druk wan Rocmaks" Verkeersopwattingen stamt uit 1995 - eveneens het onderscheid tussen "verkeersopvatting" en "verkearsopwattingen", maar trok darbij niet madrukkelijk de scheidshin ussien het gooderen- on verbithtenis-

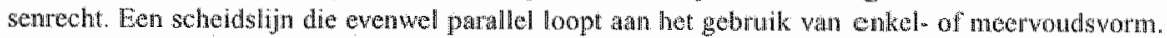
H.J. Rossel, in: 'CJFIB' (1994), p. 336-337.

81 Rossel, ar.w: 1). 336.

82 Rossel, $a$, p. 337. Anders: Whotiers, diss, p. 32

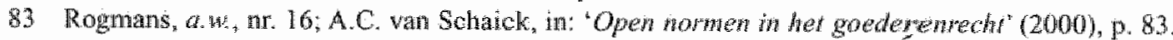

84 Doon de Hoge Rad verwoord in het arrest 'Sleppboot Egbertha' wan 26 nart 1936, N, 1936,74.

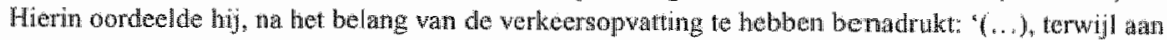
den afwijkenden wil van de betrokken personen in een bepaald gevall gekn beteckenis kan wonden toegekend, (...)."

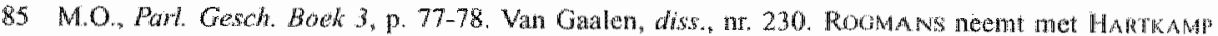
(Asser/Hartkamp (2001), nr. 293) mijns inziens torecht aan dat verkeersoupattingen ecn va bijzondering - nata deze beporkte kring - vomien van het bredere in Nederland levende rechtsowertuigh -

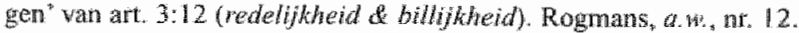

86 Rossel, $a, w, p .338$

87 Rossel, a. w. p. 339

88 Van Schaick, am. p. 89 
gediskwalificeerd, kan in een ander - en vooral later - geval juist als zodanig worden bestempeld. Uit het oogpunt van rechtszekerheid is het goed zich te realiseren dat de literatuur en de rechtspraak in deze het uitgangspunt kunnen bieden, vanuit welk een verfijning van de huidige werkeersopvatting plaats kan hebben. De flexibiliteit is de rechter geboden om een oljectieve en daarmee de rechtszekerheid dienende invulling te geven aan de hem voorgelegde rechtsvraag.

FEsEvUR verwoordde het aldus:

'Een verkeersopvatting wordt immers geacht feitelijk te bestán;, de rechter heeft ('slechts") te constateren wat haar inhoud is. ${ }^{* 9}$

\subsubsection{De afgesproken vrucht}

Het laatste lid van artikel 3:216 biedt de hoofdgerechtigde ${ }^{90}$ de mogelijkheid bij vestiging te bepalen wat de vrucht is van het bezwaarde goed. Het valt te betwijfelen of aan een dergelijke bepaling bij yestiging goederenrechtelijke werking valt toe te dichten." Het komt mij voor dat het systeem van het goederenrecht dit slechts in zeer beperkte mate zal toelaten. Een uitbreiding van de vrucht buiten de verkeersopvatting, levert naar mijn mening enkel een obligatoire verbintenis op, aangezien de verkeersopvarting beslissend is voor de bepaling van de vrucht. ${ }^{22}$ Voor verkrijging van deze vrucht dient derhalve een overdracht tussen hoofdgerechtigde en vruchtgebruiker plaats te hebben. ${ }^{93}$ Wordt de vrucht door de hoofdgerechtigde beperkt, dan blijft dezelfde redenering mijns inziens op zijn plaats. Goederenrechtelijk is de vruchtgebruiker rechthebbende geworden, maar hij is obligatoir verbonden het verkregene aan de hoofdgerechtigde over te dragen. Op deze wijze wordt een derde die afgaat op het recht van de vruchtgebruiker op de vruchten goederenrechtelijk beschermd, omdat een beperking van de vrucht door de hoofdgerechtigde in beginsel slechts de rechtsverhouding tussen vrucht-gebruiker en hoofdgerechtigde regardeert.

89 J.E. Fesevar, WNPR 6472 (2002), p. 31. Opgenerkt zij dart FhsEvuk bij dit citaat doelt op de redeIjkheid en billijkheid. Hoewed hij de verkeersopvating als open nortm niet gellik wenst te stellen met de redeltikheid en billikheid (noot 78), doet het miji inziens niet af aan de juistheid wan het citaat in het kader wan de verkeersopvatting.

90 Opmerking verdient dat het miet noodzaketijk de hoofdgerechigde behoeft te zijn die afspraken hier over makk. In geval het recht van vuchtgebruik onderdeel uitmaakt van een nalatenschap, is het veetal de orfthter die als insteller regels zal kunnen meegewen. Zie voor een bespreking hoofdstuk 3.

91 In gelijke zin Rogmans, $a$ w, wh. 39. Evenals Van Gaalen, diss., nr. 230. Zwursen bepleit daarentegen een groter belang voor de wil wan partijen bij de originaire verkrijgingsvormen wan matrekking, vermenging en zaaksworming. Het belang van reelitszekerheid noemt hij "een rookgordijn". $R$. Zwitser, MPNR 6210 (1996), p.87-88 en 91. Hij vindt datarbij in VAN SCHAICK een medestander (Von Soliaick, a.H, p.87).

92 AsserMujnssen-Van Dam-Van Velten 3-II (2002), nr. 289.

93 Van Gaalen, diss., nr. 230. 
Helemaal zonder goederenrechtelijke werking is de bovengenoemde afspraak bij vestiging niet. Inmmers, een bij herhaling afgesproken vrucht kan in potentie een vrucht ex artikel 3:9 worden. In het arrest 'Radio Holland' oordeelde de Hoge Raad dat een zaak op grond van de verkeersopvatting bestanddeel was geworden van een schip, omdat een bepaling van die strekking deel uitmaakte van "in zwang geraakte overeenkomsten'. ${ }^{94}$ Een analogie naar de vrucht valt eenvoudig te construeren. Wanneer men binnen een bepaalde praktijk standaard afspreekt dat een bepaald voordeel in de rechtsverhouding hoofdgerechtigde - vruchtgebruiker als vrucht heeft te gelden, kan zulks ertoe leiden dat de aldus afgesproken vrucht op grond van de verkeersopvatting verwordt tot de goederenrechtelijke vrucht. Exemplarisch is de wettelijke uitzondering die is opgenomen voor de termijnen van lijfrente, welke feitelijk uitkeringen van kapitaal betreffen, maar die als vruchten gelden. Deze uitzondering is opgenomen in lid 3 van artikel 3:9 wanwege 'overeenstemming met de gebruikelijke opvatting der praktijk". ${ }^{95}$

\subsubsection{Verkrijging van de vrucht}

De vruchtgebruiker wordt van rechtswege eigenaar van de natuurlijke vruchten van een goed ${ }^{\%} \mathrm{Er}$ is geen nadere handeling van vruchtgebruiker of hoofdgerechtigde benodigd. ${ }^{97}$ In tegenstelling tot de rechtstreekse verkrijging van de natuurlijke vruchten biedt de wet geen regeling voor de rechtstreekse verkrijging van burgerlijke vruchten, zulks wordt evenwel op grond van analogie met artikel 3:120-de bezitter verkrijgt de burgerlijke vruchten - aangenomen. ${ }^{98}$ Uit deze analogie volgt dat, in geval van het opeisbaar worden van een burgerlijk vrucht, de vruchtgebruiker gerechtigde is op het ontstane vorderingsrecht. Als rechthebbende van de vordering is de vruchtgebruiker inningsbevoegd.

\subsubsection{Resumerend: de burgerlijke wrucht}

De burgerlijke vrucht heeft vanwege de verwevenheid met een open norm een open karakter. De rechtspraak en literatuur concentreren zich op de vraag of het ontstane vorderingsrecht een uitkering uit het kapitaal is of een vrucht van dat kapitaal of een ander voordeel dat de hoofdgerechtigcle toekomt. ${ }^{99}$ De verkeersopvatting is bij de

94 HR 16 maart 1979, NJ 1980, 600 m.nt. BW (Radio Holland); Rogmanis, a.w, nr. 13. Zie voor meer uitspraken waar de rechter voor de verkeersopvatting verwijst naar overeenkomsten in de praktijlk; Wichers, diss., p. 93-95.

95 T.M. Parl. Gesch. Boek 3, p. 94.

96 Art $5: 17$.

97 Asser/Mijnssen-Van Dam-Van Velten 3-1I (2002), nr. 289.

98 Asser/Mijnssen-Van Dam-Van Velten 3-1I (2002), nr. 289a. VAN GAALLN (diks'. nu. 228) kont tot dezelfcle conchusie. Overigens verwijst hij daarbiy naar een passage uft Snijders-Rank-Berenschot $(1996)$, die in de nienwe druk niet is opgenomen.

99 T.J. Mellema-Kranuenburg, in: 'Preadvies Vuchtgebruik KNB' (1999), p. 23; Van Gaalen, diss., wr. 23 !. 
beantwoording van deze wraag doorslaggevend. Deze opvatting dient door de rechter buiten partijen om bij de betrokkenen uit de praktijk te worden gezocht. Eenmaal gevonden leidt dit ertoe, dat afgesproken vruchten buten deze verkeersopvatting slechts kunnen leiden tot een verbintenis-rechtelijke verplichting van de hoofdgerechtigde. De vruchtgebruiker verkrijgt deze vruchten niet van rechtswege en er zall derhalve cen expliciete overdracht van het betrokken goed moeten plaatsvinden. Dit wordt enkel anders indien de afgesproken vrucht verwordt tot de goederenrechtelijke vrucht ex artikel $3: 9$, omdat het herhaaldelijk afspreken aldus de verkeersopvatting weergeeft. ${ }^{100}$ Het is aan de rechter te beoordelen of de vlag de lading (nog) dekt.

\subsubsection{Gebriken of verbruiken}

'Een vruchtgebruiker mag de aan thet vruchtgebruik onderworpen goederen gebruiken of verbruiken overeenkomstig de bij de vestiging van het vruchtgebruik gestelde regels of, bij gebreke van zodanige regels, met inachtneming wan de aard van de goederen en de ten aanzien van het gebruik of verbruik bestaande plaatselijke gewoonten. ${ }^{\text {191 }}$

Naast het constitutieve ${ }^{102}$ gebruiksrecht van de vruchtgebruiker heeft het nieuwe Burgerlijk Wetboek tevens de mogelijkheid geopend voor de vruchtgebruiker om het bezwaarde goed te verbruiken ${ }^{103}$ In beginsel zijn de bij de vestiging vastgestelde regels maatgevend voor het gebruik of verbruik. Indien er geen regels bij vestiging zijn neergelegd dan dienen de aard van het goed en de plaatselijke gewoonten duidelijkheid te verschaffen over de manier waarop de vruchtgebruiker het goed gebruikt of verbruikt. Naar de uitleg hoe de aard van een goed en de plaatselijke gewoonten dienen te worden bepaald wordt in de literatuur vergeefs gezocht. ${ }^{104}$ In veel gevallen wordt gebruik gemaakt van voorbeelden. Het huis mag worden bewoond, met de auto mag worden gereden en de kleren mogen worden gedragen. 'Normaal gebruik' ligt besloten in de aard van het goed. ${ }^{105}$ Met KLEIN meen ik dat normaal gebruik of ver-

100 Overigens lijki mij dit een sitstekende manier van doorwerking wan de will van partijen in het gooderenrechtelijk systeem. Zij valt te prefereren boven de ingrijpende wijze die ZwirsER voorstat. Zie noor 91 .

101 Art. 3:207 lid 1.

102 Zie 8.12.

103 Doo invoering wan deze bewoegdheid brak de wetgever met de instandhoudingswerplichting die onder het oude recht woor het vruchtgebruik bestond. Voor een nitgebreide bespreking var de onhoudbaarheid van dit wereiste verwigs ik naar de bespreking in hoofdstuk 2 wan het proefschrift Van VAN GAALEN. Voor een bespreking met de Romeinsredhtelijke bril werwijs ik naar SpRurts "Cumabula iuris' (2003), p. 224 en verder.

104 Er moet van uitgegaan worden dat het gebruik ex art. 5:1 lid 2 hier niet naar analogie kan worden toegepast. De vruchtgebrutker heeft een eigensoortig gebruiksrecht in enge zin, hetgeen - oncir meer - het rech van vernietiging witsluit. Pitlo/Reehwis-Heisterkamp (2001), n. 470; SnijdersRank-Berenschot (2001), nr. 175.

I05 A.G. Lubbers, "Preadves Wnchgebruik KNB" (1959), p. 8. 
bruik als criterium, bij afwezigheid van regels van de hoofdgerechtigde, objectief bepaalbaar dient te zijn. ${ }^{106}$ Wanneer een vruchtgebruiker een goed in vruchtgebruik krijgt moet voor hem objectief vast te stellen zijn hoe hij het mag gebruiken of verbruiken. Met name de afwezigheid over wat de wetgever onder verbruiken verstaat vormt een gemis. ${ }^{107}$ Echter, aangetekend moet worden dat onder verbruik in het algemeen wordt verstaan 'het door eenmalig of meermalig gebruik teniet gaan'. ${ }^{108}$ Vervreemden valt in deze zin naar mijn smaak niet door de vruchtgebruiker onder verbruik te plaatsen. Deze conclusie wordt mede gesteund door de lex specialis die voor vervreemden naar bestemming is opgenomen in artikel 3:212.109 Wil de hoofdgerechtigde zijn vruchtgebruiker de bevoegdheid toekennen goederen "op te souperen, te consumeren of te vernietigen " 110 , dan zullyen deze bevoegdheden met behulp van de regels van artikel 3:212 en/of 3:215 vormgegeven dienen te worden. ${ }^{111}$

\subsubsection{Beheren}

Artikel 3:207 lid 2 bepaalt dat de vruchtgebruiker bevoegd is tot alle handelingen die tot een goed beheer van de aan het vruchtgebruik onderworpen goederen dienstig zijn. Hoewel het begrip beheer in het artikel niet wordt ingevuld, moet men denken aan de dagelijkse handelingen, handelingen die geen uitstel kunnen velen en voor de normale exploitatie van het goed dienstig kumnen zijn. ${ }^{12}$ Een groot aantal wettelijke verplichtingen van de vruchtgebruiker betreft in wezen uitwerkingen van lid 2 van artikel 3:207. De reden dat lid 2 spreekt van het ruime 'alle handelingen die tot een goed beheer dienstig kunnen zijn' moet volgens de Parlementaire Geschiedenis worden gezocht in de bescherming van derden. Indien voor een derde duidelijk is dat de handeling dienstig is, moet hij er van uit kunnen gaan dat de vruchtgebruiker tot deze handeling bevoegd is. In dit kader is het niet ondenkbaar dat een vruchtgebruiker bevoegd wordt geacht over een goed te beschikken. ${ }^{113}$ Omgekeerd, indien het voor de derde evident is dat de handeling niet tot een goed beheer dienstig kán zijn, mag de derde de vruchtgebruiker voor niet bevoegd houden. ${ }^{114}$

Concluderend kan worden gezegd dat de regels van beheer een tweeledig doel kennen. Enerzijds werplichten zij de vruchtgebruiker zorg te dragen woor het in vrucht-

106 W.M. Kleijn, 'Vruchtgebruik. Mon, NBW' B-10' (1990), nr. 11.

107 Kleijn, a.w, nr. 11.

108 Overgenomen uit art. 561 BW (oud), T.M., Parl Gesch. Boek 3, p. 639, A.G. Lubbers, ar.w. p. 8. Alsmede Kleijn, a.w, nr. 11 . De Hoge Raad heeft zich reeds lang geleden neggttief titgesproketn over de verbruikbaarheid van toonderaandelen. HR 16 januari 1959, NJ 1959, 355 (Swierenga), p. 873 .

109 Zo ook Kleijn, a.w. nr. 11. Anders T.R.M.P. Keijser, NTBR 2003/8, p. 437.

110 Synoniemen woor verbruiken wan de hand van LuiBisERs. A.G. Lubbers, a.w. p. 9.

111 Verwezen zij naar de bespreking $\$ 2.4,4.3$ en $\$ 2.4 .4 .4$.

112 Vergelijk voor de inhoud van het begrip "beheren" art. 3:170 lid 2.

113 MELLL:MA-KranENBUR geemt dit aan voor wat betreft het beheer van een effectenportefeuille; $T$.I. Mellema-Kranenburg, in: 'Preadvies Vruchtgebriik KNB' (1999), p. 30-31. Meer hierover in \$5.5.2. 114. Zie MvA II, Parl. Gesch. Boek 3, p. $650-651$. 
gebruik gegeven goed. Anderzijds zijn de regels gericht tot de derde die de vruchtgebruiker bevoegd mag achten woornoemde handelingen ten aanzien wan het goed te verrichten. VAN GAALEN duidt de tweedeling aan met respectievelijk de 'interne functie' en de 'externe functie' van beheer. ${ }^{15}$

\subsubsection{Beschikken}

\subsubsection{Inleiding}

Onder beschikken wordt verstaan zowel vervreenden als bezwaren. ${ }^{116}$ Wanneer gesproken wordt over de beschikkingsbevoegdheid van de vruchtgebruiker dient eerst vastgesteld te worden waarover beschikt wordt. Ten eerste kan de vruchtgebruiker beschikken over zijn recht van vruchtgebruik an sich. Dit recht is in beginsel voor vervreemding vatbaar krachtens artikel 3:223. ${ }^{17}$ De beschikkingsbevoegdheid met betrekking tot de onder het vruchtgebruik vallende goederen is een veel delicatere aangelegenheid. Titel 3.8 geeft in feite drie expliciete mogelijkheden op grond waarvan de vruchtgebruiker beschikkings-bevoegd wordt geacht. Eerstens kan de bestemming van het bezwaarde goed aanleiding geven tot het aannemen van een beschikkingsbevoegdheid bij de vruchtgebruiker. Daarnaast kan de beschikkingsbevoegdheid aan de vrucht-gebruiker worden gebaseerd op de twee aanvullende gronden uit artikelen 3:212 en artikel 3:215. De mogelijkheden worden hier achtereenvolgens besproken.

\subsubsection{Vervreemden naar bestemming}

'Voor zover aan een vruchtgebruik onderworpen goederen bestemd zijn om vervreemd te worden, is de vruchtgebruiker tot vervreemding overeenkomstig hun bestemming bevoegd. "118

De vruchtgebruiker is bevoegd een goed te vervreemden wanneer dit goed de bestemming draagt vervreemd te worden. De ruime bewoordingen zijn gekozen om niet een te star criterium neer te leggen en aldus rekening te houden met eventueel veranderende maatschappelijke opvattingen.. ${ }^{119}$

Het bestenmingscriterium vindt zijn oorsprong in de mogelijkheid een volledige onderneming in vruchtgebruik te geven. ${ }^{130}$ Men denke daarbij bijvoorbeeld aan de

115 M.S. wan Gaalen, diss. VU (2001), ne 243 en 244

116 Pitlo/Rechuis-Heisterkamp (2001), hr. 135; Snijders-Rank-Berenschot (2001), nr: 177. Van Gaalen, diss., nis. 134.

117 Het species van het recht wan gebruik en bewoning lijdt in deze uitzondering; Zie art. 3.226 lid 4. In geval van werzorgingsvmuchtgebruik ex artikel 4:30 wordt beschikking over het recht van vruchtgebruik eveneens uitgesloten; art. $4: 31$ lid 1 jo 4.23 lid 5 . Zie voor de bespreking wan het werzorgingsvruchtgebruik $\$ 3.3$.

118 Art. 3212 eerste lid.

119 T.M. Par. Gesch. Boek 3, p. 659. Kleijn, a.m, nr. 12.

120 Pitlo/Reehuis-Heisterkamp (2001), nr. 689. 
plaatselijke autohandelaar. Dat een ruime vervreendings-bevoegdheid voor de voortgang van de onderneming van vitaal belang is, is uiterst helder, Gebruikt de vruchtgebruiker deze onderneming dan moge duidelijk zijn dat de mogelijkheid tot het vervreemden van de auto's uit de voorraad cruciaal is. De klassieke auto die als publiekstrekker in de showtoom staat zal daarentegen naar zijn bestemming niet vervreend mogen worden. De regeling geeft echter weinig houvast voor andere goederen die in vruchtgebruik zijn gegeven. Mijns inziens moet een uitbreiding buiten de toepassing die de wetgever voor ogen had met de nodige voorzichtigheid worden betracht. Zulks veronderstelt echter miet dat een beschikkingsbevoegdheid, op grond van dit eerste lid, witsluitend beperkt dient te blijven tot de goederen van de genoende onderneming. Juist het betrekken van de bestemming biedt mogelijkheden om de bevoegdheden van de vruchtgebruiker aan te passen aan het goed. Naar mijn smaak kan hier de nuancering plaatsvinden die bij het gebruik node wordt gemist. Als antwoord op de objectiviteit van de aard van het goed kan de subjectiviteit van de bestemming van het goed dienen. ${ }^{121}$ De bestemming ${ }^{122}$ zie ik in deze als het doel welke de rechthebbende $^{123}$ voor het goed in gedachten theeft. ${ }^{124}$ Bestemde de hoofdgerechtigde bepali-

121 In dezelfde zin M.S. wan Gaalen, diss. VUT (2001), nr 236.

122 Als synoniem woor het woord bestemming geeft de Dilke wan Dale (2002); bedoeling.

123 De term rechthebbende behoefte hier enige toelichting. Onder rechthebbende versta ik onder omstandigheden ook de rechtswoorganger wan de hoofdgerechtigde. Voodtht thet wruchtgebruik werd gevestigd gebruikte de rechthebbende de (laten) te bezwaren goederen en bestende hij ze voor venvreemding. Dit is het referentiekader dat bepalt welke bewoegdheden de wuchgebruker toekomen. De ruimere invulling van rechthebbende heeft te maken met de verkrijging wan het techt wan vruchtgebruik krachtens erfrecht. De vruchtgebruiker verkrijgt in dat geval het vruclotgebruik na vestiging door de rechthebbende. Beiden zijn erfgenamen wan de enflater. Naar mijn smakk is het in dit geval de bestemming die de erflater aan laet goed gaf die de bevoegdheid van de wruchtgebruiker bepaald. De 'saisine' brengt mijns inziens mede dat voor wat betreft de bevoegdheid van de vruchtgebruiker ex art. $3: 212$ lid I de door de erflater bepalde bestemming leidend is en de verkrijgende erfgenaam van to bezwaten goed gehouden is deze bestemming aiet tussentijds to wijzigent. (Zie oner de saisine en erfecht verder 3.4 ) Dit lijdt slechts uitzondering in het geval het vruchtgebruik wordt vootbehoucten in het kader wan wilsrechten. In een dergelijk geval kan er een lange tijd gelegen zijn tussen de erfrechtelijke overgang w het voorbehouden wan het vruchtgebrutk door de langstlevende. De eis van behoud van bestewning op grond van de saisine voor een dergelijke lange duur schiet mijns imziens zijn doel voorbij.

124 Darmbij kan tevens opgenerkt worden dat het de vnuchitgebruiker niet wrijstat de bestraming die goederen bij aanwang van het wruchtgebruk hebben, zelfitandig te wijogen. Voor wijziging van de bestemming behoeft hij toestemning van de hoofdgenechtigde of machtiging van de kantonrechter. Aldus art. 3:208 lid 1. Overigens spreekt art. $3: 208 \mathrm{in} \mathrm{lid} 1$ over 'zakem" in plants van goederen. In de literatum is geen rechtvaardiging voor deze beperking te vinden. Marar mijn smak is niet vol te houden dat woomoemde restrictie enkel geld voor "zaken", derhat ve neem ik axth de regreling zich witstrekt ower alle goederen. In tegenstell img tot MuNSsEN (Asser/Mijustisen-Van Dam-Van Velten 3-II (2002), nr. 284) ben ik van mening chat verandering valn bestemming van een goed miet zijhde een zaak zich wél laat denken. Aandelen in kapitaalwennotschappen kunnen deze bestemmingswijziging mijus inziens onder-gaan. Voor bespreking van art. 3.208 met betrekking tot atmdelen in een kapitalvennootschap verwijs ik naar $\$ 5.5 .3$. 
de goederen uit het vruchtgebruik-vermogen woor de vestiging tot verveemding, dan komt deze bevoegdheid ook de vruchtgebruiker toe. ${ }^{125}$

\subsubsection{Uitbreiding wan de beschikkingsbevoegdheid}

De bevoegdheid tot vervreemden kan krachtens lid 2 van artikel $3: 212$ door de hoofdgerechtigde bij vestiging structureel worden witgebreid tot volledig beschikken. Men moet dan met name denken aan de bevoegdheid tot bezwaren naast de bevoegdheid tot vervreemden van lid 1 , alsmede het uitbreiden naar andere goederen dan de in het eerste lid genoende. Dit biedt de vruchtgebruiker de mogelijkheid vrijelijk over de samenstelling wan het vruchtgebruikwermogen te beslissen. Bovendien is hij gerechtigd de bestemming van goederen te veranderen. ${ }^{126}$ De hoofdgerechtigde dient zich goed te realiseren wat dit voor het vruchtgebruikvermogen kan betekenen. De vruchtgebruiker kan nu immers oorspronkelijke goederen uit het vermogen wan de hoofdgerechtigde vervreenden en cieze "substitueren" voor een vruchtrijker goed. ${ }^{127}$

Ten slotte kan de vruchtgebruiker op een meer incidentele wijze de beschikkingsbevoegdheid ontwangen op grond van artikel $3: 212$ lid 3 . Het lid fungeert gezien zijn bewoordingen - 'In andere gevalten (...)' - als een vangnet. De mogelijkheid wordt gecreéerd om de genoemde bevoegdheid te verkrijgen op grond van toestemming van de hoofdgerechtigde of machtiging van de kantonrechter. De kantontechter zal in het geval on een dergelijke machtiging verzocht wordt een belangenafweging moeten maken.

Lid 3 van artikel 212 stelt dat de machtiging alleen wordt afgegeven indien:

'(...) het belang van de vruchtgebruiker of de hoofdgerechtigde door de vervreemding of bezwaring wordt gediend en thet belang van de ander daardoor niet wordt geschaad.'

De vervreemdingsbevoegdheid van de vruchtgebruiker blijft om meerdere redenen aen heet hangijzer, waaronder het nog te bespreken onderwerp van de substitutie. ${ }^{12:}$

\subsubsection{Vervreemden en verteren}

Naast de beperkte en volledige beschikkingsbevoegdheid uit artikel $3: 212$, kent de wet de hoofdgerechtigde de mogelijkheid toe on de vruchtgebruker een bijna alomvaltend recht tot beschikking toe te kennen. Op grond van artikel 3:215 kan de vruchtgebruiker bevoegd worden gemaakt niet alleen de goederen uit het vruchtge-

125 Vgll, Van Gralen, diss., ar. 154

126 Art. 3:208 lid 2. De toekenning van deze beschikkingsteveegdheid doet het verbod wan wijzigen wan bestemining verwallen.

127 Ook WAN GAAEN makt de lezer hierop attent. Hij radt an deze untbreiding van de beschikkingsbevoegdheid aan voorwarden te onderwerpen. Van Gaalen, diss., ni. 156.

128 Zie voor de bespreking wan substitutie 2.6. 
bruikvermogen te vervreemden, maar tevens de opbrengsten uit deze vervreending te verteren. Verteren kan in dit kader worden omschreven als het beschikken over de opbrengst van wervreemding (veelal geld), met het oogmerk dit toe te eigenen. ${ }^{129}$ Aan het einde wan het vruchtgebruik kan de hoofdgerechtigde afgifte vorderen van de bezwaarde goederen ' (..) voor zover de vruchtgebruiker of zijn rechtverkrijgenden niet bewijzen dat die goederen verteerd of door toeval tenietgegaan zijn. "130 In die zin vormt artikel $3: 215$ tevens een vrijstelling van de plicht tot herbelegging uit artikel $3: 214$ lid 1.

\subsubsection{Beschiken over het goed wan een derde}

Zoals zojuist beschreven kan een vruchtgebruiker bevoegd geacht worden ten aanzien van goederen uit het vermogen van de hoofdgerechtigde. De constatering dat de vruchtgebruker bevoegd is over diens goederen te beschikken is eenvoudiger opgeschreven dan verklaard. De aard van deze beschikkings-bevoegdheid vormt terecht onderwerp van rechtswetenschappelijk onderzoek. Hoewel verschillende theorieen ${ }^{131}$ in de loop der tijd zijn geopperd, wordt een breed gedragen dogmatische onderbouwing pas gevonden in het proefschrift van GROEFSEMA. ${ }^{132}$

GROEFSEMA verwerpt de theorieën van de voorwaardelijke overdracht en de zakelijke vertegenwoordiging vanwege respectievelijk de omslachtigheid en de onmogelijkheid ${ }^{133}$. In plaats daarvan stelt hij zijn eigen theorie die gestoeld is op het Duitse recht. In de visie van GROEFSEMA vormt de beschikkingsbevoegdheid van de mietrechthebbende (beperkt gerechtigde, vruchtgebruiker) een additief en positief vereis-

129 Van Gaalen, diss., nr. 163; A.G. Lubbers, 'Predvies Vructrgebruik KNB' (1959), p. $₫ 34$. Tevens sluit ik mij aan bij de nuance die EBBEEN in dit kader aanbrengt (E. WJ. Ebben, WPNR 6480 (2002), p. 238). Verteren houdt, in tegenstelling tot wat bijwoorbeeld MELLEMA-KRANENiburg stelt (T.J. Mellema-Kranenburg, in: 'Preadvies Vruchtgebruik KNB" (1999), p. 32), niet in het uitschakelen wan de regels van zaak substitutie. Dit zou immers betekenen dat een vruchtgebrutiker die de bevoegdheid ex art. $3: 215$ toekomt een huis zou kunnen verkopen en met de opbrengst een andere (duurzam) zak te kopen deze zaak aldus buten het vruchtgebruikvermogen kan houden. Met Elariav ben ik het eens dat zulks in strijd is met de letter en de geest wan art. $3: 215$.

130 Aldus het slot van art. 3:215 lid 1 .

131 Waaronder de constructie wan MELLEMA-KRANENBURo in welke de vruchtgebruker beschikkingsonbevoegd een owerdracht bewerkstelligt en de beschikkingsonbevoegdheid achieraf door derden bescherming wordt geheeld op grond wan art. 3:86/88. Deze constructie moet natar mijn smaak varmwege haar innerlijke strijd met art. 3: 88 als anjuist worden betiteld. TJ. Mellema-Kranenburg, in: 'Preadvies V'nchtgebraik KNB' (1999), p. 37. Zo ook B. W.M. Nieskens-Isphording, WPNR 6368 (1999), p. 618.

132 L. Groefsema, diss. RUG (1993). W.C.L. van der Grinten, NJB 1993/30, p. 1088; P.A. Stein, RM Themis 1994-5, p. 243-246; O.K. Brahn en W.H.M. Reehuis, 'Overdracht. Mon. NBW' B-6a' 1997, p. 46-47; Pitlo/Reehuis-Heisterkamp (2001), m. 141; T.R.M.P. Keijser, NTBR 2003/8, p. 435.

133 De constructie van de zakelijke vertegenwoordiging wordi door GRoEFSEMA toegeschreven atan BRAtN. Bij zijn bespreking ervan acht hij de constructie zoals door BRan verdedigd niet mogetijk. Groefsema, diss., p. 72-73. Zic (op punten) anders P.A. Stein, $a$.w., p. 245. 
te voor beschikking. De niet-rechthebbende moét beschikkings-bevoegd zijn. ${ }^{134}$ Deze beschikkingsbevoegdheid kan de niet-rechthebbende op twee manieren verwerven. Ten eerste kan de rechthebbende (hoofdgerechtigde) hem in staat te stellen van zijn - de rechthebbende dus - beschikkingsbevoegdheid gebruik te maken. GROEFsEMA stelt dat de rechthebbende de niet-rechthebbende daartoe kan machtigen. ${ }^{135}$ Voor de toepassing zoekt hij aansluiting bij de lastgeving van artikel $7: 423$. $^{36}$ Deze machtiging werkt niét privatief, de hoofdgerechtigde blifft beschikkingsbevoegd. ${ }^{13 \gamma}$ Bovendien kan de bevoegdheid van de miet-rechthebbende ook uit de wet voortvloeien. ${ }^{138}$ GROEWSEMA verwijs hierbij naar de regeling van executie door pand- of hypotheekhouder ${ }^{.39}$ en de beschikkings-bevoegde vruchtgebruiker ${ }^{140}$. Met VAN GAALEN die de constructie prijst om zijn "verbluffende eenvoud"141 meen ik dat deze wijze van beschikken over het goed wan een derde de meest heldere is. In het vervolg van dit proefschrift zal ik de theorie van GRoEFsEMA als uitgangspunt nemen.

\subsection{Plichten van de vruchtgebruiker}

Zoals reeds vermeld is een aantal verplichtingen van de wruchtgebruiker vastgelegd in titel 8 van boek 3 . Zij gelden als uitwloeisels van het goed wuchtgebruikerschap van artikel 3:207 lid 2. De verplichtingen neergelegd in artikel 3:205 en volgende worden beschouwd als uit de wet voortvloeiende verbintenissen tussen vruchtgebruiker en hoofdgerechtigde. ${ }^{142}$

\subsection{1. 'Goed vruchtgebruikerschap'-arikel 3:207 lid 3}

De hoofd-en bronverplichting is de verplichting tot goed vruchtgebruikerschap. Bij deze algemene verplichting dient aansluiting gezocht te worden bij de eisen van redelijkheid en billijkheid. ${ }^{143}$ De norm van het zorgvuldig vruchtgebruik kadert de overi-

134 Groefsema, aiss p. 21-22. In tegenstelling tot de rechthebbende die mét beschikkingsonbevoegd mag zij.jin.

135 Groefsema, diss, p. 22-23. Zijn behandeling wall deze mogehikheid naar het Duitse recht wordt gevonden in $\$ 4.5$ van zijn proefsollurift.

136 Groefsema, dissi. p. 24 .

137 Groefsema, diss, p. 29. RANK-BERENSCHOI platste hierbij een punt wan kritiek (E.B. RankBerenschot, WNPR $6160(1994)$, p. 842.

138 Coroefisema, disis" ${ }^{\prime}$ p. $24-25$.

139 Groefsema, diss, p. 25 met verwijzing nar de utgebreide bespreking in hoofdstuk 6 van zijn proefscilutif:

140 Groefsema, diss., p. 156 met werwijzing natart $3: 212$ lid 1. De nitbreidimg van de beschikkingsbevoegdheid bij vestiging ziet hij als combinatie van de machtiging door de hoofdgerechtigde en de werc (j. 157).

141 Van Gaden, diss., n. 139.

142 HR 16 januari 1959, NJ 1959, 355 (Swierengay, m.nt. JHB.

143 Asser/Mijussen-Van Dan-Van Velten 3-II (2002), nr. 275. 
ge wettelijke verplichtingen verder in. ${ }^{144}$ De sanctie op het niet nakomen van deze verplichting is aansprakelijkheid wan de vruchtgebruiker voor de aldus ontstane schade jegens de hoofdgerechtigde. Belangrijk is te constateren dat bij de uitoefening van het recht van vruchtgebruik deze norm bepalend is. Wanneer een vruchtgebruiker gebruik maakt van zijn bevoegdheden zal hij dat moeten doen zoals "een goed vruchtgebruiker' dat betaamt. Onduidelijk is of dit betekent dat de vruchtgebruiker altijd de belangen van de hoofdgerechtigde dient te behartigen bij het uitoefenen van de hem toebedeelde bevoegdheden. In beginsel zal men geneigd zijn bevestigend te antwoorden. Het wordt echter een stuk minder eenvoudig wanneer de vruchtgebruiker zijn eventueel verkregen stemrecht bij vestiging op bijvoorbeeld aandelen niet anders kan uitoefenen dan met belangenbehartiging van de hoofdgereehtigde als doel. De belangen van vruchtgebruiker en hoofd-gerechtigde zullen veelal juist botsen op dit punt. Hierna zal worden verdedigd dat de vruchtgebruiker zijn stenrecht, indien verkregen, volledig naar eigen inzicht mag uitoefenen. De norm van het goed vruchtgebruikerschap komt naar mijn smaak enkel in het geding wanneer de vruchtgebruiker de hoofdgerechtigde/ aandeelhouder moedwillig schade berokkent.

\subsubsection{Enkele andere verplichtingen}

\section{Boedelbeschrijving - artikel 3:205 lid I}

Als eerste is de vruchtgebruiker verplicht bij aanvang een boedelbeschrijving te maken, tenzij een onderbewindstelling tot voldoende beschrijving heeft geleid. De boedelomschrijving geschiedt in beginsel in een notariële akte, maar kan in samenwerking met de hoofdgerechtigde ook zijn beslag krijgen in een onderhandse akte. Bovendien biedt de boedelbeschrijving in lid 2 van het artikel de mogelijkheid om bijzonderheden rond hun rechtsrelatie in de akte op te nemen.

\section{Jaarlijkse opgave - artikel 3:205 lid 4}

De vruchtgebruiker is verplicht de hoofdgerechtigde op de hoogte te houden van het reilen en zeilen van het wruchtgebruikvermogen. Eens per jaar dient hij op te geven wat er in het vruchtgebruikvermogen aanwezig is, welke goederen voor andere in de plaats zijn gekomen en welke voordellen het vruchtgebruikvermogen heeft opgeleverd.

\section{Zekerheid stellen - artikel 3:206}

De vruchtgebruiker is verplicht bij aanvang de hoofdgerechtigde zekerheid te bieden voor de nakoming van zijn verplichtingen jegens de laatste. Het artikel schrijft niet voor hoe de vruchtgebruiker zekerheid dient te bieden. Mochten de hooldgerechtigde en de vruchtgebruiker er echter niet uit komen dan kan de rechter worden ingeschakeld.

144. Van Gaalen, diss., nr. 278. 


\section{Verzekeren-artiket 3:209}

De verplichting tot verzekeren zou eerwoudig onder de verplichting tot het goed wruchtgebrukerschap ex artikel 3:207 geschaard kunnen worden, niettemin schept de wet een specifieke verplichting daartoe. De vruchtgebruiker is echter enkel verplicht de goederen te werzekeren tegen gevaren waartegen het gebruikelijk is een verzekering af te sluiten

\section{Beleggingsplicht-artikel $3: 214$}

Wanneer gelden tot het vruchtgebrukvermogen behoren, dient de vruchtgebruiker deze, in overleg met de hoofdgerechtigde, te beleggen. Goederen die als resultat van deze beleggingsactiwiteit worden verkregen vallen op grond van de hierna te bespreken substitutieregeling ${ }^{145}$ onder het vruchtgebruik en in het vermogen van de hoofdgerechtigde:

\subsection{3. 'Ernstig tekortschieten'-artikel 3:221}

De verplichtingen van de vruchtgebruiker zijn uiterst belangrijk om te vermelden, omdat bij ernstig tekortschieten van de vruchtgebruiker aan de hoofdgerechtigde een belangrijk rech"smiddel wordt toegekend. Komt de vruchtgebruiker zijn verplichtingen namelijk op een zodanige wijze niet na dat hij 'ernstig tekortschiet' 46 dan staat voor de hoofdgerechtigde de mogelijkheid open om door tussenkomst van de rechter zichzelf het beheer te verschaffen of het vruchtgebruik onder bewind te stellen (overigens kan de hoofdgerechtigde zelf ook bewind-voerder worden). Een dergelijk zogenoemd strafbewind moet onderscheiden worden van de mogelijkheid voor de hoofdgerechtigde om bij aanvang reeds het vuchtgebruik onder bewind te stellen krachtens artikel 3:204. Een onderbewindstelling van deze aard wordt veelal ingesteld ter bescherming van de vruchtgebruiker en de hoofdgerechtigde tegen elkaar in het kader van een legaat. ${ }^{47}$ Dit in tegenstelling tot artikel 3:221 waaruit duidelijk de bescherming van de hoofdgerechtigde spreekt.

Voor beide bewindsystemen geldt als voornaamste rechtsgevolg het verlies wan beheer door de vruchtgebruiker. ${ }^{148}$ Opgemerkt dient te worden dat in tegenstelling tot

1452 id do bespreking in 2.6.

146 Overigens is "tekontshteten" strikt genonen niet ruim genoeg. De Hoge Raad oordeelde in het arrest van "Van OpstalWan Miert" dat ook in het welleden begane ernstige tekortkomingen grond kunnen bieden voor de besprolken sanctie, zulks ondat de regeling tevens dient 'ter voorkoming van zodanig in de toekomst te duchten tekorstschieten." HR 9 december 1994, WJ 1995,224 (Vam Opstal Kan Mhent), no. 3.3.

147 T.J. Mellema-Kranenburg, in: "Preadvies Whohgebruik KNB" (1999), p. 55.

148 Aangezien onder beheer tewens word verstan het uitbrengen wan stemrecht, komt dit recht indien overgedragen an de wrohtgebruiker nu de bewindvoerder toe. E.B. Beremschot, WPNR 5730 (1985) p. 173. Asser/Mijussem-Van Dam-Van Velten 3-11 (2002), ar. 308. 
de bewindbepalingen van Bioek 1 die grotendeels van toepassing zijn ${ }^{40}$, de wruchtgebruiker wel over zijn recht van vruchtgebruik kan bljven beschikken.

\subsection{Substitutie ${ }^{150}$}

\subsubsection{Inleiding}

VAN GAALEN definieert substitutie als "de juridische constructie waarbij een recht op een uit een vermogen verdwenen goed automatisch ontstaat op het goed dat daarvoor in de plaats treedt" ${ }^{15 t}$ Substitutie is een vorm van originaire verkijging. ${ }^{152}$ De wetgever heeft het niet wijs geacht om een algemene regeling op te nemen voor de substitutie, in plaats daarvan is voor een aantal gevallen een speciale regeling in de wet opgenomen. ${ }^{153}$ Voor het recht van vruchtgebruik is de regeling neergelegd in artikel 3:213. Lid 1 begint als volgt:

'Hetgeen in de plaats wan aan vruchtgebruik onderworpen goederen treedt doordat daarover bevoegdelijk wordt beschikt, behoort aan de hoofdgerechtigde toe en is eveneens aan het vruchtgebruik onderworpen (...). 154

Het leerstuk van de substitutie was een noodzakelijk gevolg wan het verdwijnen van de instandhoudingsverplichting ${ }^{155}$ en als zodanig een "novum'156 in de regelingen

149 Zie woor een overzicht van de toepasselijke bewindbepalingen uit Boek ; Asser/Mijnssen-Van Dam Van Velten 3-1I (2002), nir: 304-317.

150 Onder het oude recht werd gesproken wan zaakswervanging. De terminologie houdt ook nu nog wel eens stand (Pitlo/Reehuis-Heisterkamp (2001), hr. 689). Aangezien natar huidig recht tevens andere goederen dan zaken voor deze tegeling in aanmerking komen is het zuiwerder te spreken wan substitutie: Vergelijk Asser/Mijmssen-Van Dam-Van Velten 3-Il (2002), nr. 298; Snijders-RankBerenschot (2001), nr. 294 en M.S. van Gaalen, diss. $W U(2001)$, nr. 107.

151 Van Gaalen, diss., nr. 114. VAN GAALN verwijst vool de rotstandkoming van deze definitie natr de definties van $\mathrm{LANGEMELBR}$ en HAMMERSTEN dis zij in hum proefschrifien hobbon opgenomen.

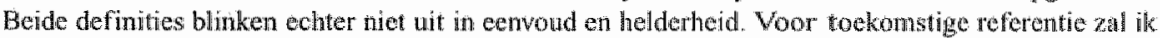

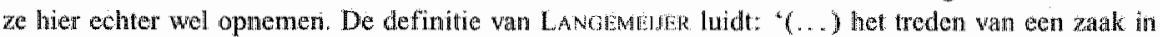
een rechtsbetrekking, op gnond dat hat ontstan of har verkriging door een bepald persoon onmiddellijk samenhangt met het werlies van een andere zank, die zich tevoren in een gelike rechtsbetrekking bevond." GE. Langemeijer, diss. RUL (1927), p. 5. HAMMARSTIN definieert zalakverwanging (lees: substitutie) als wolgt: "Het van rechtswege in de plaats treden van een goed als object van een recht voor een goed dat als object van datzelfde recht is werd wenen op grond dat het nieum we goed is verkregen als wergoeding voot het verlies wan de vermogenswadrde valu het oorspronkclijke goed en met als doel te voorkomen dat het betreffende recht door het verifwijnen van het oorspronkelijke teriet gaat.' A. Hanmerstein, diss. KUN (1977), 9.97.

152 Art. 380 lid 3.

153 Snijders-Rank-Berenschot (2001), nr, 294.

154 Art. $3 * 213$ lid 1.

155 Zic hierover de verwijzing naar de bespreking door VAN GA ALE in zijn noot 103.

156 B.W. N. Nieskens-Isphording, WPNR 6081 (1993), 136. 
over het vruchtgebruik. Omdat de vruchtgebruiker onder het huidige recht in bepaalde gevallen de bevoegdheid krijgt wolledig over de onder het vruchtgebruikvermogen vallende goederen te beschikken, diende een regeling te worden getroffen waardoor het beschikken mogelijk was zonder dat het vruchtgebruik of het goed verloren ging voor respectievelijk vruchtgebruiker en hoofdgerechtigde. De vereisten voor substitutie alsmede de twee rechtsgevolgen die het in bet leven roept worden in de navolgende paragrafen besproken.

\subsubsection{Bevoegdelijk beschikken}

De meest cruciale voorwaarde voor een geslaagde substitutie is dat de vruchtgebruiker bevoegdelijk en in eigen naam ${ }^{157}$ beschikt over een goed uit het vruchtgebruikvermogen. ${ }^{158}$ Wordt er onbevoegdelijk beschikt door de vruchtgebruiker dan treedt hetgeen daaryoor terugkomt niet in de plaats van het goed waarover werd beschikt. ${ }^{159}$ Bevoegdelijke beschikking kan geschieden op grond van artikel 3:212 $2^{150} \mathrm{en} / \mathrm{of} 3: 215$.

\subsection{3. 'behoort de hoofdgerechtigde toe.}

Het eerste rechtsgevolg dat in artikel 3:213 lid 1 valt te lezen is dat hetgeen in de plaats treedt van het goed waarover bevoegdelijk beschikt is, gaat toebehoren aan de hoofdgerechtigde. De substitutieregel bewerkstelligt dat door een rechts-handeling van de vruchtgebruiker de hoofdgerechtigde een - bezwaard - goed verkrijgt. De substitutieregeling strekt zich daarnaast uit over vorderingen welke door de vruchtgebruiker worden geïnd, alsmede andere voordelen die het vruchtgebruikvermogen opbrengt welke geen vruchten betreffen. Dat het goed waarover bevoegdelijk wordt beschikt van rechtswege toebehoort aan de hoofdgerechtigde, maakt dat deze vorm van verkrijging ${ }^{161}$ een bijzondere aard kent. De hoofdgerechtigde is immers rechthebbende van een goed geworden zonder dat hij daar zelf de hand in had. ${ }^{162}$

157 Beschikt de wruchtgebruiker in naam wan de hoofdgerechtigde dan is van substitutie geen sprake, omdat aangenomen kan worden dat op grond van de regels wan vertegenwoordiging de hoofdgerechtiggde geacht wordt zelf partij te zijn bij de beschikking en aldus verkrijgt. Pitlo/ReehuisHeisterkanp (2001), nr: 141.

158 MvA II, Parl. Geseh. Boek 3, p. 661-662.

159 Zie woor de behandeling van het onbevoegdelijk beschikking door de wruchtgebruiker $\$ 2.6 .5$.

160 De Toelichting Meijers verwijst expliciet naar dit artiket. TM., Parl. Gesch. Boek 3, p. 660.

161 Het is nuttig er op te wijzen dat het hier uitsluitend de verkrijging betreft, hetgeen niet verward mag worden met de beschikking door de vruchtgebruiker. Vervreemding door middel van de driehoeksvertiouding thoofdgerechtigde - vruchtgebruiker - derde werd besproken in \$2.4.4.

162 Bj zorgvuldige lezing wan de definitie van HAMMERSTEIN blijkt de verkrijging door de hoofdgerechtigde geen deel uit te maken van deze definitie. HAMMERSTEN meent dat dit rechtsgevolg 'oneigenlijke zakswernanging" betreft. Zie woor de definitie noot 151 supra. 


\subsection{1. 'de leer van de directe verkrijging' en substitutie}

\section{De stand van zaken}

De hierboven omschreven verkrijging door de hoofdgerechtigde verdient een nadere bespreking. Sinds KLEIN ${ }^{163}$ wordt in de literatur de substitutie uit artikel 3:213 gekoppeld aan de 'de leer van de directe verkrijging' vervat in artikel $3: 110.164$ De directe leer dient in deze als de dogmatische onderbouwing van de verkrijging door de hoofdgerechtigde. Deze leer; die ook wel bekend staat als "normatieve verkrijgingsleer'165, houdt in dat de rechtsverhouding tussen twee partijen een verkrijging door een der partijen kan normeren. ${ }^{1660}$ Op grond van de genoemde rechtsverhouding wordt niet de contracterende partij verkrijger van het goed, maar de wederpartij in de achterliggende rechtsverhouding, zulks ongeacht de wil van de contracterende partij. In het geval van de vruchtgebruiker krijgt deze op eigen naam, maar in opdracht en voor rekening van de hoofdgerechtigde een goed geleverd, dat vervolgens op grond van de directe leer rechtstreeks in het venmogen van de hoofdgerechtigde vloeit, zonder daarbij ooit deel uit te maken van het vermogen van de vruchtgebruiker. De combinatie met de substitutieregel van artikel 3:213 brengt met zich mee dat het goed ten behoeve van de vruchtgebruiker van rechtswege met het recht van vruchtgebruik is bezwaard.

De toepassing wan de directe leer werd door de Hoge Raad evenwel beperkt. Hij oordeelde dat de genoemde constructie enkel mogelijk is bij goederen die door middel van bezitsverschaffing geleverd worden. In dat opzicht schakelt bet bewuste 'Kas-Associatie/Drying Corp'- arrest ${ }^{167}$ toepassing bij onroerende goederen, orderpapieren en vorderingen op naam uitdrukkelijk ${ }^{168}$ uit. In rechts-overweging 3.5 oordeelt de Hoge Raad:

${ }^{6}$ De thans op artikel 3:110 BW te gronden (...) directe leer, kan slechts worden toegepast op goederen waarvan de levering plaatsvindt door - zoals arti-

163 W.M. Kleijn, "Wruchgebraik. Motw NBW B-10" (1990), nu. 17.

164 Zo ook B.C.M. Waaijer, WPNR 6115 (1993), 9. 891; T.J. Mellema-Kranenburg, in: Preadves Frachrgebrwk KMB' (1999), p. 38 en Wan Galen, dist., nr. 117. Kennelijk ook Snijders-RankBerenschot (2001), nir: 599 .

165 KLELN (a.w, nr. 17) spreekt nog van "de leer wan de normatieve verkrigging". In de literatuur spreekt men meestal wan "leer van de directe verkrijging" of "directe leer". Van Gaalen, diss, m. I I7; Pitlo/Reehuis-Heisterkamp (2001), ni. 304; Snijders-Rank-Berenschot (2001), 437. Alsook de HR 23 september 1994, NJ 1996, 461 m.nt. WMK (Kas-Assaciarie/Drymg Corp), ro. 3.5. Mrullak spreekt in zijn proefschrift wan 'de lear wan directe verkrijging'; S.Y.Th. Meijer, diss. WV (1999), p. 178.

166 Andere auteurs menen dat niet deze nom de bexitswerkriging van de 1 oof dgerechtigde bewerkstelligt, matr de wet. Asser/Van der Grinten-Kortmann 2- (2004), nr. 130 en Meijer, diss., p. 187-188.

\67 HR 23 september 1994, NJ 1996, 461 mint. WMK (Kas Associanie/Dinging Conp).

$₫ 68$ In minder expliciete bewoordingen werd eerder in thet hilema te bespreken "Modelwuis Nolly"-aturest eenzelffe conclusie door de Hoge Rat getrokken. 
kel 3,90 het witdrukt en voorts ook van belang is voor de toepassing van artikel $3: 93$ - de verkrijger het bezit daarwan te verschaffen." $" 6 \%$

Het argument wan gewicht in deze uitsprak word gevonden in een eerder gewezen arrest van de Hoge Raad inzake verkrijging door een middelijk vertegen-woordiger. In het inmiddels beroemde ${ }^{170}$ arrest Modehuis Nolly' ${ }^{\prime 7 \%}$ oordeelde de Hoge Raad dat een ten name van een lasthebber ${ }^{172}$ gesteld onroerend goed, ondanks de onderliggende rechtswerhouding, niet tot het eigendom van de lastgever kon behoren, ondat zulks in strijd is met kenbaarheid uit de registers voor derden.

Hij oordeelde:

"(...) dat een dergelijke wijze van elgendomsverkrijging van onroerend goed onverenigbaar is met artikel $671 \mathrm{BW}^{[173]}$ en met de door dit wetsvoorschrift beoogde openbaarheid van de eigendomsverkrijging van onroerend goed door middel van overdracht:"174

De uitgebreide formaliteit van levering ex artikel $3: 89$ en de bescherming van ingeschreven feiten ex artikel 3:24 verhinderen dat de hoofdgerechtigde eigenar wordt. De tenaamstelling is doorslaggevend woor de eigendomswerkrijging. ${ }^{175}$ Wordt een

169 'Kas-Associatie/Drying Corp', r.o. 3.5.

170 Zie onder meer P.A. Stein, AA 1976, p. 759 en wolgende, A.VM. Struycken, WPNR 5370 (1976), p. 738 en verder. Na terugwerwijzing van de Hoge Raad naar het Hof kwam er een vervolgarrest: HR 16 magrt 1984, NJ 1984, 556 (Modehuis Nolly /h). Het arrest blies nieuw leven in de discussie. C.A. Kraan, WPNR 5730 (1985); M.J.A. van Mourik, WPNR 5702, 5712 (1984) en 5730 (1985); H.C.F. Schoordijk, WPNR 5712 (1984), en 5730 (1985) en meer recentelijk W.M. Kleijn, WPNR 6247 (1996).

171 HR 2 april 1976, N/ 1976, 450 m.nt. WMK (Modehuis Nolly). Het arrest is naar mijn smaak echter tot op zekere hoogte a-typisch. In het arrest beoogden pautijen juist dat het onroerend goed goederenrachtelijk gezien uit het zicht van de lastgever werd gemanocuvreerd, teneinde het aan potentiële nitwinning te onttrekken. Dat de lasthebber op grond wan de uitspraak als eigenaar dient te gelden, inag in dat gevil geen verrassing heten. Aangenomen moet worden dat de hoofdgerechtigde dit in zijn rechtsverhouding met de wrichtgebruiker noeit zal beogen. Laat staan dat de wuchtgebruiker zulks zonder betrokkeriheid wain de hoofdgerechtigde kan bewerkstelligen. Zulks doet echter niet af aan de uitsluiting van de normatieve verkrijging indien het onsoerende goed op naam van de houder wordt gesteld. Overigens is de constructie kennelijk niet bestand tegen art. 61 Faillissementswet en malkt zij slechts kans te slagen buiten faillisgement. H.C.F. Schoordijk, WPNR 5712 (1985), p. 568; M.IA. van Motrik, WPNR 5712 (1984), p. 572-573.

172 Hoe de feitelijke verhouding juridisch gekwalificeerd diende te worden was in de literatuur met name voorwerp van discussic. Vergelijk de bronnen in noot 171 supra.

173 Het oude art. 671 is in het nieuwe BW ondergebracht in artt. 3:24 en 3:89 betreffende respectievelijk de openbare registers en de overdracht van onroerend goed.

174 "Modehuis Nolly", p. 1323.

175 T.ll. Mellema-Kranenburg, in: 'Preadwes Vruchtgebrwik KNB" (1999), p. 36 en Asser/Mijnssen-Van Dam-Van Velten 3-11 (2002), nr. 298 
onroerend goed op naam van de vruchtgebruiker gesteld dan is, ondanks de substitutieregel van artikel 3:213, goederenrechtelijk niet anders te concluderen dan dat de vruchtgebruiker ten opzichte van derden als eigenaar dient te gelden. ${ }^{176}$ Het gebrek aan effect van de normatieve verkrijging in deze situatie wordt ondervangen door de 'doorleveringsleer' welke leer degene die op naam verkrijgt de last meegeeft het betrokken door te leveren aan de beoogde verkrijger. STEIN ${ }^{177}$ bespreekt in zijn noot deze leer in aansluiting op het arrest 'Modehuis Nolly' en in het vervolgarrest verplicht de Hoge Raad ${ }^{178}$ de lasthebber tot deze doorlevering. ${ }^{177}$ Aangenomen wordt dat deze doorleveringslleer ook valt toe te passen op door 'Kas-Associatie/Drying Corp' eveneens buitengesloten vorderingen op naam. ${ }^{180}$

In een latere uitspraak zaait de Hoge Raad echter verwarring ten aanzien van de directe verkrijgingsleer, substitutie en de goederen op welke deze regelen van toepassing kunnen zijn.

In het arrest 'MeesPierson/Ten Bos c.s. ${ }^{181}$ oordeelde de Hoge Raad:

'Indien, zoals het middel hier tot uitgangspunt neemt, de vrucht-gebruiker van een vermogen de bestanddelen daarvan bevoegdelijk heeft vervreemd en de opbrengst vervolgens heeft herbelegd door storting op een afzonderijke beleggingsrekening, geldt naar het vóór 1 januari geldende recht - evenats thans in gevolge artikel 3:213 $\mathrm{BW}$ - dat die opbrengst en het aldus onstane tegoed op die beleggingsrekening tot het aan het vruchtgebruik onderworpen vermogen blijven behoren; hetzelfde geldt voor de vervolgens uit dat tegoed aangekochte en afzonderlijk geadministreerde effecten [cursief van mij, $E C B]: \mid 182$

De casus vertoont grote overeenkomsten met de casus in 'Kas-Associatie/Drying Corp': In beide uitspraken gaat het om een houder (respectievelijk vruchtgebruiker en middellijk vertegenwoordiger) die beschikt over een goed van een derde (hoofd-

176 Anders: B.W.M. Nieskens-Isphording, WPNR 6368 (1999), p. 619

177 P.A. Stein, AA 1976, p. 762 en 764. Vergelijk ook Asser/Van der Grinten-Kortmann 2-1 (2004), nt. 131.

178 HR 16 maart 1984, $N$ f 1984, 556 (Moderiuis Nolly ID), r.o. 3.2.

179 Ironisch genoeg eiste de lastgever zulks reeds eerder in de procedure. Het Hof beschouwde deze eis als 'niet ernstig geneend". "Modehuis Nolly", p. 1320-1321.

180 Zie Rb Amsterdam 20 februari 1985, NJ 1986, 113 m.nt. FHUM (Hadisantoso/Flesseman a.q.). Annotator Minsssen ging nog een stap verder en concludeerde dat niets er aan in de weg stond dat de middellijk vertegenwoordigde 'rechtstreeks verkreeg' en de in allit gewall de deelgerechtigdheid in de WGE nooit tot het vermogen wan de middellijk wertegenwoordiger heeft behoord. FilliLiNk onderschreef deze conclusie K. Frielink, WPNR 5945 (1990), p. 37). De uitspratk van 'KussAssaciatie/Drying Corp' achterhaalde deze nobele gedachte.

181 HR 9 januari 1998, NJ 1999, 285 m.nt. WMK (MeesPterson/Ten Bos).

182 'MeesPierson/Ten Bios', r.o. 3.3. 
gerechtigde, principaal). In het laatstgenoemde arrest wijst de Hoge Raad toepassing van de directe leer uitdrukkelijk af, in tegenstelling tot voormelde uitspraak 'Mees Pierson/Ten Bos c.s.' waarin hij oordeelt dat het verkregen goed wél aan de hoofdgerechtigde toebehoort. Twee verklaringen zijn hiervoor denkbaar. De eerste verklaring ligt verscholen in de door mij gecursiveerde tekst. KORTMANN meent dat het hier kennelijk om effecten gaat die buiten de Wet giraal effectenverkeer vallen en derhalve roerende zaken betreffen. De Hoge Raad spreekt van 'afzonderlijke beleggingsrekening' en 'afzonderlijk geadministreerde effecten'. ${ }^{183}$ Effecten als roerende zaken, welke door bezitsverschaffing kunnen worden geleverd, vallen wél binnen het toepassingsgebied van de directe leer. De andere verklaring is dat de beleggingrekening en de aangekochte effecten op naam staan en voor rekening zijn van de hoofdgerechtigde (Ten Bos c.s.) en de vruchtgebruiker niét in eigen naam handelde, maar de hoofdgerechtigde vertegenwoordigde. Echter, in de uitspraak wordt juist geoordeeld dat omstreden is wie de rekeninghouder nu feitelijk was. ${ }^{184}$ Bovendien legt de Hoge Raad uitdrukkelijk het verband met artikel 3:213, hetgeen na 'Kas-Associatie/Drying Corp' onmogelijk wordt geacht voor wat betreft de vorderingen op naam. Geconcludeerd moet worden dat de Hoge Raad kennelijk de route volgt die KorTMANN ons wijst.

De onontkoombare conclusie van het voorgaande is dat de koppeling van de directe leer aan het leerstuk van de substitutie een tweedeling brengt in de dogmatische onderbouwing van de substitutie. Enerzijds blijft de regeling van de directe leer overeind voor wat betreft roerende zaken die bezwaard zijn met het recht van vruchtgebruik. Anderzijds ontbreekt de toepassing van de directe leer als onderbouwing voor goederen die niet direct verkregen kunnen worden met als ultieme consequentie dat in deze gevallen geen sprake is van substitutie. ${ }^{185}$ De zienswijze van de Hoge Raad zorgt ervoor dat de directe leer als een waar koekoeksjong de uitgesloten goederen van 'Kas-Associatie/Drying Corp' uit het nest van de goederenrechtelijke substitutie van artikel 3:213 wipt, althans wat haar dogmatische onderbouwing betreft.

Nu het vruchtgebruik op goederen gevestigd kan worden en derhalve de toepassing van substitutie van vorderingen op naam geadresseerd dient te worden, komt een

183 JOR 1998, 116 m.nt. Kortmann, p. 787. In zijn noot komt KLEJ eveneens tot de conelusie dat hier zalakswerwanging is opgetreden, echter zonder te concluderen dat het hier (kennellik) om niet-Wos andelen en dus roerende zaken gat Zie noot 181 .

184 "Meespierson/Ten Bos", r.o. 3.1.

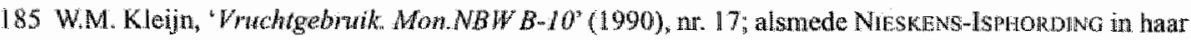
bespreking varl de monografte van KLEHN. B.W.M. Nieskens-Isphording, WPNK 608॥ (1993), p.

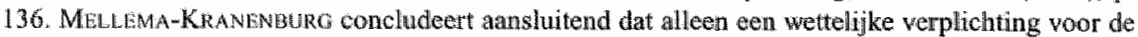
Whohtgebruiker on mee te werken aan een juiste tenamstelling soelaas zom kumnen bieden. T. Mellema-Kranenburg, in' 'Preadwes Wruchtgebruik KNB' (1999), p. 39. Overigens komt NuESENiSISpHORDiva later op har zhenswijze terug en conchudeent dat de wettelike regeling van art. $3: 2.13$ de arresten "Modehuis Nolly" en 'Kas-Associatie/Dryng Corp" doorkraist. B.W. NieskensIsphording, WPNR 6368 (1999), p. 619. Meer hierover in het hieropkolgende paragrat: 
dergelijke tweedeling mij niet als helder woor. Het feit dat, in het geval van roerende zaken, de substitutie met toepassing van artikel 3:110 doorgang kan vinden, terwijl andere goederen van een dergelijk geëffend pad verstoken blijven, draagt meer dan een zweem van willekeur. ${ }^{186}$ Hoewel in de literatuur de controverse wordt gerelati$v^{2} \mathrm{rd}^{187}$ is een eenduidige opvatting te verkiezen. Immers, de argeloze lezer zal deze goederenrechtelijke nuance, waarin onderscheid gemaakt wordt woor de betrokken goederen, in artikel 3:213 ten enenmale ontgaan.

De oplossing voor bovenstaand dilemma kent in feite twee gedaanten ${ }^{188}$ Ten eerste kan men verdedigen dat de categorie goederen die direct kan worden verkregen uitgebreid moet worden, zodat ook vorderingen op naam direct kumen worden verkregen. Ten tweede kan men de oplossing bij de wortel van het kwaad zoeken en de koppeling van artikel 3:213 met artikel 3:110 verwerpen.

\section{Alternatief 1: uitbreiding van de directe leer}

Het voornaamste bezwaar waar de literatuur op stuit bij de uitbreiding van de directe leer is de conclusie uit het arrest 'Modehuis Nolly'. De kenbaarheid uit openbare registers is een argument van zwaar kaliber en kan naar mijn smaak niet worden weersproken. De vruchtgebruiker die in eigen naam bevoegdelijk beschikt over een goed, waarvoor een onroerende zaak in de plaats treedt dat op zijn naam wordt gezet, is in goederenrechtelijke zin eigenaar geworden van voornoemde onroerende zaak. Alleen de doorleveringsleer biedt hier soelaas. Het argument verliest echter iets van zijn kracht voor wat betreft de vordering op naam. In tegenstelling tot onroerende zaken spelen de openbare registers in beginsel geen rol bij de kenbaarheid voor derden inzake de gerechtigdheid tot de vordering. Degene die, naast de beschikkende vruchtgebruiker en de verkrijgende hoofdgerechtigde, een primair belang heeft bij de overdracht van een vordering op naam is de debiteur van deze vordering. Bij de directe verkrijging van een recht op naam wordt de vordering door de vruchtgebruiker op diens naam verkregen, maar is de hoofdgerechtigde de eigenlijk rechthebbende. Hoewel de overstap naar uitbreiding in dit kader verleidelijk is, komt hij mij niet als verstandig voor. De directe verkrijging van vorderingen op naam leidt tot ondoorzichtige eigendoms-eroudingen. Daarnaast kunnen vorderingsrechten complexe vormen aannemen - vergelijk bijvoorbeeld het aandeel in een kapitaalvennootschap wardoor het moeilijk wordt om de uiteindelijke rechthebbende te achterlzalen.

186 Pregnant is in dit geval dat juist aandelen zaken of vorderingsrechten betreffen. De bespreking van de vestiging wath wruchtgebruik op andelen in hoofdstuk 4 gaat hier verder op in.

187 Asser/Van der Grinten-Kortmann 2-I (2004), nr. 133.

188 NIESK ADS-lSPHOEDNG opperde een derde mogelijheid. Zij stelde als oplossing voor goederentech telijk onderscheid te maken tussen eigendom in de interne verhouding (wruchtgebruiker - hoofdgerechtigde) en de externe verhouding (vruchtgebruker - derden). B. WM. Nieskens-Isphording, WPNR 6081 (1993), p. 619. Een dergelijke oplossing lijkt mij dognatisch gezien cen hoilloze weg. Deze "relatiwiteit in eigendom" past overigens ook niet in "het ransel" van VAN Mourik (M.J.A. van Mourik, WPNR 5702 (1984), p. 382). 
Daarmee pleit ik in het kader van de rechtszekerheid en helderheid van eigendoms. verhoudingen tegen de uitbreiding van de directe leer.

\section{Alternatief 2: onikoppeling van artikel $3: 213$ en 3:110}

Hoewel de literatuur vrij algemeen de presumptie van KLEIJN aanvaard, zijn vraagtekens hierover op zijn plaats. Is het imperatief dat het verband tussen de substitutie van artikel 3:213 en de directe verkrijgingsleer wordt gelegd? Het gevolg is immers dat de toepassing wan artikel 3:213 wordt beperkt tot de categorie goederen als onischreven in "Kas-Associate/Drying Corp". Valt met NIESKENS-ISPHORDINC aan te nemen dat de wettelijke regeling inzake substitutie niét doorkruist kán worden door deze uitspraak? " "Kas-Associatie/Drying Corp' ziet immers niet rechtstreeks op de bedoelde substitutieregel, maar volgt uit de koppeling met de directe leer. Het is verdedigbaar dat de substitutieregel van artikel 3:213 van wetswege verkrijging van de hoofd-gerechtigde met zich brengt. Naast NiESKENS-ISPHORDING lijkt ook MEuER zulks aan te nemen. ${ }^{190}$ Dit zou echter inhouden dat ook in het geval van een vruchtgebruik-casus analoog aan 'Modehuis Nolly'; de vruchtgebruiker op wiens naam de onroerende zaak is gesteld, niet daadwerkelijk eigenaar is van de onroerende zaak. Een dergelijke conclusie schiet mijns inziens haar doel voorbij. De kenbaarheid uit de openbare registers komt hiermee inmers op losse schroeven te staan. De rechtzekerheid die door genoemde registers word gecreeerd, wordt door de ontkoppeling opgeofferd. De ontkoppeling vormt daarmee geen werkbaar alternatief.

\section{Afshitiend}

Het dilemma dat door de koppeling van substitutie en de directe leer ontstaat is geenszins eenvoudig op te lossen. Enerzijds leidt de koppeling ertoe dat de goederen uitgesloten door 'Kas-Associatie/Drying Corp' niet door de hoofd-gerechtigde rechtstreeks worden verkregen. De goederenrechtelijke bescherming die de substitutieregel aan de hoofdgerechtigde poogt te bieden gaat daarmee verloren. De doorleveringsleer kan dit verlies niet ondervangen. Anderzijds heeft de door NieskENSISPHORDNO betoogde interpretatie eveneens belangrijke nadelen. Het meest in het oog lopende nadeel is strijd met de openbare registers inzake de overdracht van onroerende goederen: Wanneer men aanneemt dat de wettelijke substitutieregeling van artiket 3:213 het arrest 'Kas-Associatie/Drying Corp' opzijzet, betekent dit dat een op naam van de vruchtgebruiker staande onroerende zaak tot het vermogen van de hoofdgerechtigde kan behoren. Een dergelijke discrepantie tussen ingeschreven feiten en de juridische rechts-verhouding is in strijd met de rechtszekerheid en valt reeds om die reden niet te prefereren. Naar mijn smaak is het derhalve niet opportun de door NIESKENS-ISPHORDING ingeslagen weg te volgen. De goederenrechtelijke be-

189 B.WM. Nieskens-lsphording, WPNR 6081 (1993), p. 619: Vergelijk ook de benadering die MELER hanteert waar het de directe verkrijging betreft. Hij oordeelt dat er sprake is van verkrijging van wetswege. Meijer, diss, p. 188.

190 Meijer, diss, p. 189 en werder. 
scherming van de hoofdgerechtigde tegen de beschikkingsbevoegde vruchtgebruiker dient op een ander vlak zijn beslag te krijgen. Overigens besteed ik in hoofdstuk 7 nader aandacht aan de rechtsverhouding tussen de vruchtgebruiker en zijn hoofdgerechtigde.

\subsubsection{Conclusie}

Het koppelen van de directe leer aan de substitutieregeling van artikel 3:213 wordt breed gedragen in de literatuur. Dat daarmee substitutie van rechtswege woor de registergoederen en vorderingen op naam uitgesloten wordt lijkt in eerste instantie onbevredigend. De hoofdgerechtigde is voor het verkrijgen van het goed waarover bevoegdelijk beschikt is afhankelijk van de doorlevering door de vrucht-gebruiker." De beperking die de substitutie als gevolg van de directe leer in zich draagt, klent temeer nu de argeloze lezer van artikel 3:2\3 een uitzondering voor de genoende goederen niet zal vermoeden. Overigens mag hem of haar dat niet eens kwalijk genomen worden nu de wetgever een expliciete voorziening heeft opgenomen voor het innen van vorderingen. Tot fundamentele problemen zal deze dogmatische onvolkomenheid naar mijn smaak echter niet snel leiden. Een niet onbelangrijk argument voor deze conclusie is gelegen in het uitschakelen van de substitutieregel voor vruchtgebruikvormen krachtens nieuw erfrecht. ${ }^{192}$ De onontkoombare conclusie lijkt mij dan ook dat, voor de gevallen waarin de vruchtgebruiker voor de hoofdgerechtigde goederen werkrijgt die niẻt direct verkregen kunnen worden, de vruchtgebruiker gehouden is niet in eigen naam te verkrijgen, maar in naam van de hoofdgerechtigde. Aldus vertegenwoordigt hij de hoofdgerechtigde en verkrijgt deze laatste.

\subsection{4. "is eveneens aan het whichtgebruik onderworpen"}

Het tweede en voor de vruchtgebruiker meest belangrijke rechtsgevolg betreft het behoud van zijn recht van vruchtgebruik. Het goed dat in de pllaats treedt van het goed waarover beschikt is - en in het vermogen van de hoofdgerechtigde valt - is van rechiswege bezwaard met het recht van vruchtgebruik. Er is met name gén vestigingshandeling vereist voor ontstaan van dit wruchtgebruik. ${ }^{193} \mathrm{De}$ regel vain "droit de

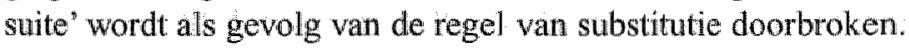

191 Overigens ligt het voor de hand dat de vruchtgebruiker onder voorbehoud wan vruchtgebruik aan de hoofdgerechtigde zal doorleveren.

192 Art $4: 23$ lid 3 sluit de substitutie uit voor het voorbehouden vruchtgebruik bij wilsreeluten. Voor hei verzorgingswruchtgebruik krachtens artikel $4: 30$ wordt deze regeting opnieuw ingesehakeld (art. $4: 23$ lid 3 is in dit geval met wan overeenkomstige toepassing verklaarcl in 4.31 lid 1 ). Vergellijk $\$ 3.2 .3$ en $\$ 3.3 .4$.

193 Van Gaalen, diss., nr. 115 


\subsubsection{Financiering uit het vermogen wan de vruchtgebruiker}

Een voorstelbaar probleem ontstaat wanneer de vruchtgebruiker met eigen financiën én met de opbrengst van een bevoegdelijk vervreemd goed een nieuw goed koopt. In hoeverre valt dit nieuwe goed onder de substitutieregeling van artikel 3:213? De literatuur ${ }^{194}$ zoekt aansluiting bij de regeling in het huwelijksvermogensrecht, meer in het bijzonder artikel 1:124. Dit houdt analogisch geredeneerd in dat wanneer de vruchtgebruiker voor meer dan $50 \%$ zelf bijdraagt aan de financiering van een goed er geen zaaksvervanging optreedt. In plaats daarvan resteert een vordering uit schadevergoeding voor de hoofd-gerechtigde. NIESKENS-ISPHIORDING oordeelt de constructie als onbevredigend en oppert orn in dit geval mede-eigendom aan te nemen. Het nieuwe goed is in inede-eigendom van vruchtgebruiker en hoofdgerechtigde. Bovendien is het deel van de hoofdgerechtigde op grond van de regels van substitutie bezwaard met het recht van vruchtgebruik ten behoeve van de vruchtgebruiker. ${ }^{195}$ Beide oplossingen hebben hun merites, niettemin richten beide zich te veel op een bepaalde samenstelling van het vruchtgebruikvermogen. Betreft het één enkel goed, dan valt de constructie van het mede-eigendom vanwege haar goederenrechtelijke karakter te verkiezen boven het obligatoire schadevergoedingsrecht. Omvat het vrucht-gebruik daarentegen meerdere goederen, vervalt het bezwaar van het obligatoire karakter vanwege het voortbestaan van het vruehtgebruik op de andere goederen. Daarmee heeft de hoofdgerechtigde een instrument in handen om zekerheid te krijgen. In het uiterste geval kan de hoofdgerechtigde een onderbewindstelling afdwingen op grond van artikel 3:221. Deze constructie valt te verkiezen boven een algemene regel van mede-eigendom welke de vruchtgebruiker ten aanzien van het goed dwingt om samen te werken bij zowel het beheer als een mogelijke beschikking. Gezien de tegenstrijdige belangen die bij partijen leven ${ }^{196}$, kan een uiteindelijke gang naar de rechter niet worden uitgesloten.

\subsubsection{Onbevoegdelijk beschikken}

Beschikt de vruchtgebruiker (of de hoordgerechtigde) onbevoegdelijk dan kan er geen sprake zijn van substitutie. ${ }^{197}$ Aangenomen wordt dat een door bekrachtiging ex

194 WM. Klejin. "Wrehtgebrwk. Mon.NBW B 10' (1990), wr. I6, Assen/Mijnssen-Van Dam-Van Velten 3-Il (2002), m. 298; T.J. Mellema-Kranenburg, in. "Preadvies Vtuchgebnuk KNB" (1999), p. 34-35.

195 H. W.M. Nieskens-Isphording, WPNR $63.68(1999)$, p. 618.

196 Doze tegenstrijdige belangen laten zioh het sterkst voelen hn geval vam aundelen. De wruchtgebruker is gebaat bij een vruchtrijk (heel) goed. De hoofdgerechtigde daanentiegen zal het creeren van vruchten tegengaan on het 'weglekken' wan waardestijgingen te woorkomen. Meer over deze verhoutingen in hoofdstuk 6.

197 WAulv vaagt zich af warom de wetgever de hoofdgerechtigde in deze niet beschermd heef door ook in deze gevallen substitutie van toepassing te laten zijn. B.C.M. Waaijer, WPNR 6115 (1993), p. 891. 
artikel 3:58 geheelde overdracht wel substitutie kan bewerkstelligen. ${ }^{198}$ Wat rest voor de hoofdgerechtigde bij onbevoegdelijk beschikken door de vruchtgebruiker is een vordering uit schadevergoeding. Enkel wanneer er zich nog andere goederen in het vruchtvermogen bevinden, beschilt de hoofdgerechtigde over het pressie-middel van artikel 3:221 zoals hierboven omschreven.

\subsection{Conclusie}

De conclusie dat het recht van vruchtgebruik het meest gecompliceerde beperkte recht in het Nederlandse goederenrechtelijk systeem vormt lijkt in geen geval een overdrijving. Een aantal aspecten van het vruchtgebruik leidt in het bijzonder tot deze conclusie. Zo valt te noemen de mogelijkheid van vestiging op alle soorten goederen. Daar waar de andere beperkte rechten tevens beperkt zijn voor wat betreft het object van bezwaring, wordt het recht van vruchtgebruik niet op een dergelijke wijze begrensd. Daarenboven zijn er weinig grenzen die de bevoegdheidsverdeling tussen vruchtgebruiker en hoofdgerechtigde bepalen. Het Nederlandse goederenrecht is in dit geval uniek in de zin dat de vruchtgebruiker in staat kan worden gesteld het vruchtgebruikvermogen te verteren. De vruchtgebruiker kan in verregaande mate de bevoegdheden van de eigenaar uitoefenen. Naast het recht op de vruchten dat de vruchtgebruiker uit de aard van het vruchtgebruik toekomt, kunnen een recht tot beschikken en zelfs verteren aan de vruchtgebruiker worden toegekend.

De verregaande mate waarin de vruchtgebruiker in staat wordt gesteld over het goed te beschikken alsmede de mogelijkheid om het recht van vruchtgebruik op alle soorten goederen te vestigen, kent echter ook een keerzijde. Vooreerst leidt de uitgebreide beschikkingsbevoegdheid van de vruchtgebruiker tot een verzwakking van de positie van de hoofdgerechtigde. Alhoewel het uitgangspunt is dat de hoofdgerechtigde zelf de vruchtgebruiker deze bevoegdheden toekent en derhalve zelf deze verzwakking in de hand heeft, strookt dat uitgangspunt niet met de praktijk. Zo zal het recht van vruchtgebruik niet altijd door de hoofdgerechtigde worden gevestigd, althans niet op zijn initiatief. Uit het volgende hoofdstuk zal blijken dat het erfrecht krachtig inzet voor wat betreft het gebruik van het vruchtgebruikinstrument. In dat geval wordt (een deel van) de nalatenschap van de erflater als het ware gesplitst in vruchtgebruik en hoofdgerechtigdheid. De vestiging dient weliswaar nog plaats te hebben, maar de voorwaarden van verkrijging en vestiging van vruchtgebruik worden door het testament of het ab intestaat erfrecht gegeven. De positie van de hoofdgerechtigde dient in het kader van de beschikkingsbevoegde vruchtgebruiker met name wettelijke versterking te krijgen in de substitutieregeling. Ook deze regeling

198 Van Gaalen, diss., nr. 128 alsmede T.J. Mellema-Kranenburg, in: 'Preadvies Vruchygebruk KNB' (1999), p. 34. Zij stelt echter "heling" bij derdenbescherming gelijk aan de bekrachtiging thetgeen fundamenteel onjuist moet worden geacht. Vergelijk B.W.M. Nieskens-lsphording, WPNR 6368 (1999), p. 618. Zie tevens noot 131. 
wordt evenwel geconfronteerd met de rekbaarheid van het recht van vruchtgebruik. Voor wat betreft de substitutie van zaken sluit de directe leer naadloos aan bij de substitutieregeling en is de hoofdgerechtigde verzekerd van het behoud van het vruchtgebruikvermogen. De uitbreiding naar andere goederen dan zaken leidt echter tot problemen. Zodra het bezwarde goed niet door middel van bezitsverschaffing kan worden geleverd hapert de directe leer Goederen die op grond van het arrest 'KasAssociatie/Drying Corp' uitgesloten zijn van directe verkrijging door de hoofdgerechtigde moeten door de vruchtgebruiker wordt doorgeleverd. Zijn goederenrechtelijke verhouding met de betrokken goederen kan slechts na naleving van deze vordering tot doorlevering worden hersteld. 


\section{Hoofdstuk 3}

\section{VRUCHTGEBRUIK EN ERFRECHT}

\subsection{Inleiding}

Het rechtsgebied waar de vruchtgebruikconstructie ronduit populair is, is zonder twijfel het erfrecht. In het nieuwe erfrecht dat sinds 1 januari 2003 van kracht is wordt een belangrijke plaats ingeruimd voor het wuchtgebruikregime. Zowel op grond van dwingend als wan regelend recht bestaat de mogelijkheid om het recht van vruchtgebruik in het leven te roepen. Onder het oude erfiecht speelde het recht van vruchtgebruik eveneens een rol wan betekenis. In de testamentaire sfeer werd met een zekere regelmaat een zogenaamd "vruchtgebruiktestament" opgemaakt. Zowel de wijze van ontstaan onder het oude recht, als onder het nieuwe recht, zullen in dit hoofdstuk onder de loep worden genomen teneinde een zuiver beeld te schetsen van de persoon van de vruchtgebruiker. Op deze wijze kan de wraag beantwoord worden ten behoeve van wie het recht van vruchtgebruik wordt gevestigd en wat daarmee wordt beoogd. Elke mogelijkheid die het erfrecht biedt on een recht van vruchtgebruik op aandelen te vestigen zal worden besproken. Nadat aldus een overzicht van de mogelijkheden van wruchtgebruik is geschetst zal in de slotparagraaf van dit hoofdstuk een bijzonder onderwerp worden aangesneden: de verkrijging wan aandelen krachtens erfrecht. Naast de vraag woór wie het recht van vruchtgebruik wordt gevestigd is immers cruciaal te weten dón wie bedoeld recht gevestigd dient te worden. Dit laatste werpt licht op de persoon die beschikkingsbevoegd dient te zijn om het recht van wruchtgebruik in het leven te roepen. Op dit onderwerp kruisen regels van erfiecht en goederenrecht het pad wan het vennootschapsrecht. In de laatste paragraaf zal bijzondere aandacht uitgaan naar dit onderwerp.

Aldus wordt getracht de herkomst van dit beperkte recht op een aandeel weer te geven en daarmee de rechtspositie van de vruchtgebruiker in de arena wan het ven= nootschapsrecht verder invulling te geven en af te bakenen.

1 Wet $\operatorname{van} 22$ aingustis $2002,516,2002,430$ 


\subsection{Vruchtgebruik onder het oude erfrecht}

In november 1945 werd door de Hoge Raad het woor de langstlevende echtgenoot ${ }^{2}$ uitermate belang-wekkende arrest 'De Visser $/ \mathrm{Harms}^{3}{ }^{3}$ gewezen. In dit arrest oordeeide de Hoge Raad dat een beschikking in een uiterste wil strekkende tot verzorging van de langstlevende opgevat diende te worden als een voldoening aan een tussen echtgenoten bestaande natuurlijke verbintenis. Tot deze uitspraak was de rol van de echtgenoot, zeker in het versterferfrecht, uiternate klein. ${ }^{4}$ De naturlijke verbintenis hield onder het oude recht in dat de langstlevende het recht had on het leefpatroon zoals dat tijdens het huwelijk bestond na overlijden van de echtgenoot zoveel mogelijk voori te zetten. De kwalificatie als natuarlijke verbintenis betekent onder meer dat voldoening ervan aldus niet zonder rechtsgrond geschiedt. De uitspraak had een direct effect op de testamentaire praktijk en zorgde voor een stroom aan verzorgingsmakingen ten behoeve van de langstlevende. Binnen deze stroom zijn twee hoofdvormen van testamenten te onderscheiden. Ten eerste de ouderlijke boedelverdeling en ten tweede het vruchtgebruiktestament. De ouderlijke boedelverdeling ${ }^{5}$ die gebaseerd werd op artikel 4:1167 (oud) is veruit het populairst gebleken. ${ }^{6}$ De regeling houdt in dat de langstlevende alle tot de nalatenschap behorende activa krijgt toebedeeld. Daarnaast werden twee verplichtingen bij deze toedeling opgenomen. Ten eerste diende de langstlevende alle schulden van de nalatenschap voor zijn rekening te nemen en ten tweede rustte op de langstlevende de verplichting om uit het overige de andere erfgenamen hun erfdeel in geld uit te keren. ${ }^{7}$ De populariteit van deze regeling werd mede toegeschreven aan de mogelijkheid tot het opzij zetten van

2 Hiema: langstlevende. Naar feit van algemene bekendheid is in en klassiek man-vrouw huwelijk de langstlevende (nog steeds) veelal de vronw. In vervolg ga ik daar van uit, tenzij anders vermeld.

3 IR 30 november 1945, NJ 1946, 62 (De Visser/Harms). Voor een (relatief) recente en uitgebreide bespreking van dit belangwekkende arrest, zie WR. Meijer, in" "Soons-bundel' (1995), p. 105 en verder:

4 Pas in 1923 zorgde een wetswijziging ervoor dat de echtgenoot werd opgenomen in dle eerste groep vän erfgenamen naast de kinderen wan de erflater. Tot die tijd kon de echtgenoot pas erven wanneer tot en met de twallde grad (9) geen bloedwerwanten waren gewonden. Hoewel verschillende handbouken van het voorafgaande gewag maken (Handboek Nieuw Ertrecht $(2002)$, p. 1 - noot 2; Asser/Perrick 6A (2002), nr. 46; Klatassen-Luijten-Meijer (2002), nr. 30; PitlorVan der Burght (1997), ni: 7) blijit het een feit watrvoor verbazing past.

5 Herna: OBV

6 Uit een onderzoek van de Katholieke Universiteit Nijmegen in 1995 blijkt dat bijna $75 \%$ wan de uiterste willen een OBV betreft tegen nog geen $14 \%$ wilsbeschikkingen met een vruchtgebruikregime (klassiek vruchtgebruik, vruchtgebruik met verteringsbevoegdheid en universeel keuzelegaat met vruchtgebruik), M.J.A. van Mourik, L.C.A. Verstappen en Schols F.W.J.M. WPNR 6218 (1996), p. 246. LuuTt $N$ concludeert in een bijdrage dat de $O B V$ 'de verzorgingsmaking par excellence" is. E.A.A Luijten, WPNR 6034 (1992), p. 71.

7 Art. 1167 BW (oud). Asser/Van der Ploeg-Perrick (1996), nr. 511 . Overigens is het in dit geval juister te spreken wan de horizontale $O B V$, dit ter onderscheid wan de verticale $O B V$ welke verkrijging van de nalatenschap door de kinderen bewerkstelligt. Handboek Nieuw Erfrecht (2002), p. 74. 
de legitieme portie in goederen ${ }^{8}$ en de preadviezen terzake de OBV van LumTreN en ROMBACH${ }^{9}$. De klassieke OBV roept geen vruchtgebruikregines in het leven en zal dientengevolge geen onderwerp van onderzoek voor dit proefschrift vormen. ${ }^{10}$ Mijn aandacht gaat uit naar de andere vorm van het verzorgingstestament: het vruchtgebruiktestament.

\subsubsection{Het wruchtgebruiktestament}

Het vruchtgebruiktestament kent verschillende verschijningsvormen en variaties waaronder het keuzelegaat ${ }^{1}$, het ik-vader-testament en het (super)turbotestament ${ }^{12}$. Hoewel alle een specifiek doel hebben en aldus zonder twijfel een eigen bestaansrecht kunnen claimen, pogen ze eenzelfde doel te bereiken. Dat doel is het vestigen van een recht van vruchtgebruik op (een gedeelte van) de nalatenschap van de erflater door middel van een legaat. ${ }^{13}$ Opvallend is daarbij dat het belangrijkste aspect niét

8 HR 12 mei 1972, NJ 1973,53 m.nt. KW (Meerzich). De legitiene portie bood onder het oude recht - art 4:960, onder het nieuwe erfrecht is dit deels gewijzigd-arfgenamen het recht bun wettelijk erfdeel uit de nalatenschap op te eisen wam om het ewen wie de goederen wit die nalatenschap had verkregen. Voorheen konden de erfgenamich afdwingen dat hun legitieme in goederen werd uitgekeerd, hetgeen voor de verkrijgers van de goederen wit de nalatenschup natuullijh niet bepaald goed nieuws was. Het zojuist geciteerde 'Meerzicht"-arnest zette dit element wan de legitieme portie voor wat betreft de OBV opzij. Bovendien hadden de erfgenamen het recht deze goederen "vrij en onbezwaard' te verkrijgen. De legitieme portie neemt in het erfiecht ten controversiel a rol tin geturge de vele verhandelingen in dit kader. Een literatmiroverzicht met betreklaing tot deze discussie rond de

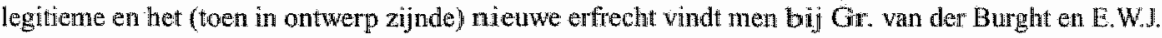
Ebben, WPNR 6349 (1999), p. 197. In het niewwe erfrecht is de legitieme portie blijwen bestan, maar rest echter alleen een vordering in gelld: art. 4:80 hid 1 .

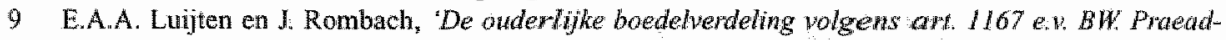
viezen wigebracht voor de Broederschap der Candidaat-Noranisen" (1958).

10 Sinds 1996 is het mogelijk gebleken de OBV te conbineren met een vruchtgebruikregime dankzij de erkenning door de Hoge Raad van de "tenxij-clausule' (HR 17 januari 1996, BNB 1996, 11.2c). Men spreetct wan en voorwardelijke OB $\mathrm{V}$. De combinatie betreft echter een keuze fop bepalde punten》, waardoor het karakter van het vruchtgebrtik, zoals dat hierna in \$3.2.1 wordi besproken, behouden blijf. Voor de bespreking van het arrest verwijs ik naar S. Perrick, HPNR 62 14 (1996), E.A.A. Luijten, WPNR 6231 (1996) en B.M.E.M. Schols, WPNR 6308 (1998).

11 Het (universele) keuze-legaat biedt de legataris de mogelijkheid on gooderen tegen inbremg van de waarde uit de malatenschap te kiezen. De inbrengworderingen kunnen baeward worden met een recht van vruchgebruik ten behoeve van de erfgenamen. Een keuze-legat wordi veelal gecombi neerd mel de voorwaardelijke OBV. K.M.F.J. Houben, WPNR 6504 (2002), p. 669 .

12. Het "urbotestowew" is vart de hand van E. B. van der Stok, WFR 6227 (1996). B.M. F. M. SCHOLS bespreakt het lot van deze testamentwomm alsmede het "superturbotestament". B.M.E.M. Schols, WPNR 6362 (1999). Beide vormen zijn overigens varianten op hetzelfide thema namelijk ed recht van wuchtgebruik op de hele huwelijksgemeenschap. De langstlevende brengt in deze vormen zijn deel vän de huwelijksgemeenschap onder voorbehoud wan een recht wan wuchtgebruik in, in de nalatenschap wan de erflater. Vervolgens werkrigt de langstlevende een recht wan vinchtgebruik op de goederen uit de nalatenschap hetgeen na diens inbreng neerkomt op ecn recht vruchtgebruik op de gehele huwelijksgemeenschap.

13 Vergelijk Van Gaalen, diss., m. 189. 
is de aard van het onderliggende goed, maar de karakteristiek van het vruchtgebruik als beperkt recht. De vruchtgebruiker kan een verregaande bevoegdheid tot gebruik en beheer worden toebedeeld zonder dat het goed daarbij juridisch tot zijn vermogen behoort. Aldus snijdt het mes aan twee kanten; de langstlevende wordt verzorgd ${ }^{14}$ en het goed loopt niet het gevaar uit de familie te verdwijnen ${ }^{15}$. Daarenboven wordt fiscaal gezien een voordeel behaald, omdat bij het overlijden van de langstlevende de aanwas van het bloot-eigendom van de erfgenamen naar vol engendom niet successierechtelijk belast is. ${ }^{16}$ De combinatie van civielrechtelijke en fiscaalrechtelijke eigenschappen maakt het vruchtgebruik tot een aantrekkelijk instrument om in te zetten bij de planning van het vermogen van een natuurlijk persoon in verband met diens - onvermijdelijke - overlijden. ${ }^{17}$ De mogelijkheid dat het vruchtgebruik op aandelen een rol kan spelen in deze vermogensplanning werd overigens geillustreerd bij de invoering van de bijzondere regeling inzake vruchtgebruik en pandrecht op aandelen. ${ }^{18}$ De MVJ oordeelde dat het vestigen van een recht van vruchtgebruik op een aandeel steeds mogelijk moet zijn juist vanwege het vruchtgebruik als instrument ter verzorging van de langstlevende."

De langstlevende ontvangt bij legaat een vorderingsrecht tot het vestigen van een recht van vruchtgebruik op de nalatenschap, een recht dat door de overige erfgenamen moet worden gevestigd. Het recht van vruchtgebruik ontstaat uitdrukkelijk niet van rechtswege. ${ }^{20}$ Daarnaast is het niet mogelijk een vrucht-gebruik te vestigen op de gehele nalatenschap als zodanig en zal elk goed dat woor vestiging van een recht van vruchtgebruik in aanmerking komt bezwaard dienen te worden. ${ }^{21}$ Dit brengt de langstlevende als de (toekomstige) vrucht-gebruiker in een lastig parket. De langst-

14. Op deze manier wordt gebruik gemaakt van de aan het leven van de wruchtgebruiker gekoppelde duur van het vruchtgebruth. Zie \$3.3.

15 Zie voor de utgebreide bespreking van dit zogeheten 'stieffawilie-gevaur' 33.2 .

16 De aanwas wormt niet een overdracht of owergang hetgeen tot gevolg heef dat deze danwas niet wordt belask. In plats daquan wordt belasting geheven bij het overlijden van de water en de vesliging van het vituchtgebüu. Eowvondig gezegd word het goed verdeed in een recht van wuchtgebrutk en een thoofdgerechtigdhend warbij de warde wan het onbezwarde goed wordt verminderd

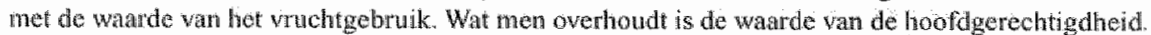
Zowel het wochtgebruik ats de hoofdgerechigdheid worden vervolgens naat hun warde belast (art. 10 jo art 21 thd 9 Snceessiewet). Bij de waardering van het recht van vmuchtgebruik wordt onder kndere de leeftijd van de vnchtgebruiker in ammetking genomen (art: $5 \mathrm{~V} / \mathrm{m}$ 10 Uitvaeringsbeshit Successicwet 1956). Het zo-even besproken (super)tubo-testament maskt(e) gebruik wan deze fis-

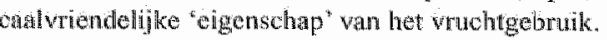

17 Deze planning wordt ook wel geduid als 'distate plonning".

18 Wiet vat 17 mei $1976,5 \%, 287$.

19 Komerstuken $111973-1974,12897, \mathrm{nr}, 3, \mathrm{p} .4$.

20 HR 11 thei $1984, N / 1985,374 \mathrm{mnt}$. WMK (Fothoeven/Perens). Het legat dient slechts als titel voor de vestiging wan het recht wan vinuchtgebruik. Er is dus geen sprahice van een algemene titel. Zulks geldt ovenzer woor het legat wan een goed. Er vindt een overdracht plaats met als titel het legaat en de logataris vet krijgt het goed onder bijondere titel.

21 Pitlo/Van der Burght (1997), p. 333, Assen/Van der Plocg-Pertick (1996), nor 380. 
levende is overgeleverd aan de medewerking van de erfgenamen voor de vestiging van het recht van vruchtgebruik.

\subsubsection{Legaat van wruchtgebruik op een specifiek goed}

Voorstelbaar is dat de erflater wél de aard van het onderliggende goed in gedachten heeft gehad bij de legatering van het vruchtgebruik. Kiest de erflater in zijn uiterste wil ervoor specifieke bestanddelen uit zijn nalatenschap te bezwaren met een recht van vruchtgebruik ten behoeve van een legataris, dan moet aangenomen worden dat de aard van de goederen zelf daarbij een rol speelt. Het feit dat de erflater er bewust voor kiest bepaalde goederen voor bezwaring aan te bieden kan bepalend zijn indien onduidelijkheid ontstaat over de bevoegdheden of de uitoefening ervan door de vruchtgebruiker. Alsdan zal de rechtspositie van de vruchtgebruiker niet zonder meer op dezelfde voet kunnen worden ingevuld als in de situatie waarin de vruchtgebruiker een algemener recht van vruchtgebruik toebedeeld heeft gekregen. Zo meen ik dat indien de erflater of insteller bewust kiest voor het bezwaren van aandelen met het recht van wruchtgebruik, hij daarmee tevens de vennootschaps-rechtelijke implicaties beoogde. Dit leidt overigens natuurlijk geen twijfel indien de erflater bij het betrokken legaat bepaalt dat de vruchtgebruiker tevens het stemrecht dient te ontvangen.

\subsection{Vruchtgebruik in het nieuwe erfrecht}

\subsubsection{Nieuw erfrecht}

De totstandkoming van het nieuwe erfrecht kent een lange en bewogen geschiedenis. ${ }^{22}$ Zowel van regeringszijde als van de zijde van de wetenschap en de notariële praktijk werden uiteenlopende voorstellen geformuleerd, verdedigd en (deels) naar de prullenbak of het rijk der fabelen verwezen. ${ }^{23}$ Voor dit proefsehrift het meest in het oog lopende was het voorstel tot het verstrekken van een recht van vruchigebruik met beschikkingsbevoegdheid aan de langstlevende. ${ }^{24}$ Ook dit vruchtgebruikvoorstel sneuvelde uiteindelijk. ${ }^{25}$ De voorstellen van de zijde van het notariaat en praktijk. wonnen na verloop van tijd aan (wervings)kracht. ${ }^{26}$ Het doel dat door de diverse

22 Voor en uigebreide behandeling verwijs ik naar het Handbock Nieuw Erfrecht (2002), hoofdstuk I.

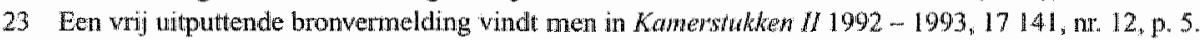

24 Voor een bespreking zie VAN MOURUK's serie artikellen ("De meeslepende awonturen van de langstle. wende echtgenoot" $1 \mathrm{Um}$ III) in $N / B$ 1982/1 en $1982 / 2$, alsmede $N / B$ 1991/31. P1ERrick bespreekt in dit kader specifiek de rechtspositie van de langstlevende als vuchtgebrulker op aandelen. $\mathrm{S}$. Perrick, NF 60 (1982), p, $140-145$.

25 Kamersukken II 1996-1997, 17 141, ne. 21.

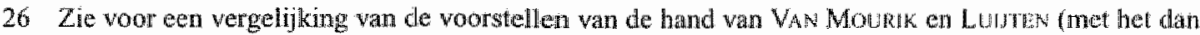
aanhangige wetsvoorstel) Commissie Erfrecht, WPNR 6055 (1992), p. 493-496. 
opstellers wan woor te stellen wetgeving werd gedeeld, was de verbetering van de positie van de langstlevende echtgenoot. Het is dan ook niet verwonderlijk dat deze positie een belangrijke, zo niet cruciale, rol speelt in het nieuwe erfrecht. De keuze van de wetgever uit de verschillende voorstellen viel, mede ingegeven door de eenvoud ervan en de ervaring ermee in de praktijk, op een wettelijk systeem gebaseerd op de ouderlijke boedelverdeling; de wettelijke verdeling. ${ }^{27}$ Hoewel het vruchtgebruik als hoofdrolspeler in het erfrecht bij versterf van het toneel is verdwenen, duikt het wruehtgebruik nog wel op als prominente bijrolspeler in verband met onder andere het stieffamiliegevaar en de verzorging van de langstlevende.

In een limitatief aantal gevallen kan in het nieuwe versterferfrecht een recht van vruehtgebruik op goederen uit de nalatenschap worden gevestigd. Ten eerste kan het recht van vruchtgebraik worden voorbehouden door de langstlevende indien (een van) de kinderen een zogenaamd wilsrecht uitoefenen. ${ }^{28}$ De tweede mogelijkheid tot het vestigen van een recht van vruchtgebruik wordt in het leven geroepen op grond van afdeling 2 van Boek 4 getiteld 'Andere wettelijke rechten'. Aldaar wordt de langstlevende in de gelegenheid gesteld om met de medewerking van de erfgenamen een recht van vruchtgebruik te vestigen op goederen uit de nalatenschap. ${ }^{29}$ Daarnaast kan de erflater het recht van vruchtgebruik door middel van een legaat aanbieden aan een legataris. ${ }^{30}$ Ten slotte heeft de wetgever ervoor gekozen de regels van het vruchtgebruik te betrekken bij een bepaald soort makingen. ${ }^{31}$

Daar de bovengenoemde vormen van vruchtgebruik elk een eigen doel dienen en daardoor nuanceverschillen in de rechtspositie van de vruchtgebruiker kunnen optreden, worden de vormen afzonderlijk in de navolgende paragrafen behandeld. Alvorens specifiek in te gaan op deze vormen van vruchtgebruik zal eerst een korte schets van het betrokken rechtsgebied worden gemaakt. In deze schets zullen zowel het versterferfrecht als het testamentaire erfrecht aan bod komen.

\subsubsection{Het versterferfrecht}

Het nieuwe versterferfrecht werkt in grote lijnen als volgt. De niet van tafel en bed gescheiden echtgenoot ${ }^{32}$ verkrijgt, bij overlijden van de erflater, van rechtswege diens

27 Do keuze werd toegehicht door de MvJ in een notitie getiteld: "De positie van de langstlevende echtgenoot en vande kinderen itw een nieuw versterf-erfiecht', Kamerstukkew II $1995-1996,24665$, nr. 1. Uitwerking wa deze notitie vond verwolgens plaats in de Toelichting bij de Vijfde Nota wan Wijziging, Kawershkhen $I / 1996-1997,17141$, n. 21. Zie voot eet eerste bespreking $\mathbb{E}$.A.A. Luigten, MJ.A. van Mourik en Commissie Erfrecht, WPNR 6260 (1997), p. 291 en werder.

28 Zie voor de bespreking wan dit voombehouden vauchtgebruik 83.4 .

29 Zie voor de bespreking wan het verzorgingswruchtgebruik $\$ 3.5$.

30 Zie voor do bespreking wan het legat van vachtgebruik $\$ 3.6 .2$.

31 Zie voor de bespreking van de regels van het vruchtgebruik en de voorwaardelijke makingen $\$ 3,6.3$.

32 Gelieve op voet van art. I.80a daar war ik spreek wan echtgenoot tevens de geregistreerd partmer te begrijper. 
gehele nalatenschap. ${ }^{33}$ De langstlevende is gehouden de schulden uit de nalatenschap te voldoen. ${ }^{34}$ De kinderen van de erflater verkrijgen als erfgenamen ${ }^{35}$ van rechtswege en krachtens erfrecht een niet-opeisbare vordering op de langstlevende ter waarde van hun erfdeel. ${ }^{36}$ De niet-opeisbaarheid is een direct gevolg van de wens van de wetgever de langstlevende verzorgd achter te laten. ${ }^{37}$ Deze vordering wordt pas opeisbaar in een van de gevallen van artikel 4:13 lid 3.

De wettelijke verdeling ${ }^{38}$ stoelt in sterke mate op de praktijk van de ouderlijke boedelverdeling. ${ }^{39}$ Daar waar de wettelijke verdeling hoofdzakelijk beoogt de langstlevende te verzorgen worden de zogenaamde 'wilsrechten' 40 ingevoerd om de belangen van de kinderen te waarborgen. ${ }^{41}$ De wilsrechten uit de artikelen 4:19 tot en met. $4: 22^{42}$ werden in het leven geroepen om het 'stieffamilie-gevaar' te beteugelen. ${ }^{43}$ Het stieffamilie-gevaar manifesteert zich onder meer wanneer de langstlevende na over-

33 Art 4:13 lid 2. Voor het vereiste van 'niet van tafel en bed gescheiden'; 4:13 lid 6, alsmede art. 4:10 lide 1 sub a.

34 Art. 4:14 lid 1. Dit betekent overigens niet dat de langstlevende deze schulden wit eigen zak betailt en de kinderen en andere erfgenamen aldus profiteren. De schulden van de nalatenschap worden betaald uit de nalatenschap. De hierna te bespreken rechten van de overige erfgenamen betreffen her saldo van deze nalatenschap, hetgeen erwoor zorgt dat elk der erfgenamen zijn deel in de schulden draagt. Handboek Nieuw Erfrecht (2002), p. 54.

35 De erfgenamen bij versterf worden gevonden in het zogenaamde parentelenstelsel. De zojuist genoemde echtgenoot en de kinderen van de erflater bevinden zich in de eerste parenteel. Art. 4:10. Voor een bespreking van dit parentelenstelsel alsmede aspecten van plaatsvervulling verwijs ik kortheidshalve naar Handboek Nienw Erfrecht (2002), hoofdstuk III.

36 Art. 4:13 lid 3.

37 Kamersinkken II 1996-1997, 17 141, mr. 21, p. 15.

38 Het woord 'verdeling' is in dit verband een tikkeltje misleidend, anngezien de langstlewende in feite de gehele nalatenschap verkrijgt en er aldus geen wezenlijke verdeling plaatsvindt, laat staan op enig moment sprake is wan een onverdeeldheid. Ook goederenrechtelijk gezien verkrijgt de langstlevende van rechtswege en rechtstreeks. Levering wan de goederen is niet vereist. Kamerstukken II 1996

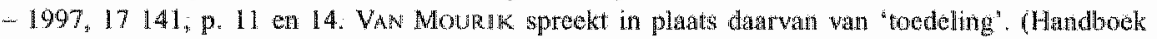
Nieuw Erfiecht (2002), p. 48), EBabiN prefereert 'toekenning'. (E. W.J. Ebben, diss. VU (2000)', p. 23), VAN GAALEN sluit zich bij hem aan. (Wan Gaalen, diss., m. 062) Nu het hicr mijn inziens een semantisch verschil betreft, houd. ik mij, na het attent maken op de taltechnische onzuiverheid, bij de bewoordingen van de wettekst.

39 Handboek Nieuw Erfrecht (2002), p. 47; Asser/Perrick 6A (2002), nr. 60.-

40 Zie woor een uitgebreide bespreking van wilsrechten in het algemeen, alsmede verbijzonderd in hell nieuwe erfrecht; SNIDDERS in achtereenvolgens WPNR 6365, 6366 en 6367 (1999).

4 II De Mvi stelt dat op deze manier "een passend evenwicht is bereikt tussen de belangen van de echtgenoot en van de kinderen". Kamerstukken $/ / 1997-1998,17$ 141, nr. 25, p. 10. Een evenwicht dat vervolgens overigens moeiteloos door de erflater kan worden verstoond. Zie het slot van deze paragraaf.

42 Wanneer in het wervolg gesproken wordt van wilsrechten worden de rechten uit art. 4:19-22 bedoeld, tenzij anders vermeld.

43 De versterking van de positie van de kinderen in een dergelijk geval is een langgekoesterde doelstelling voor het nieuwe erfrecht. Kamersfuthen I/ $1992-1993,17141$, nr. 12, p. 3. 
lijden van de erflater opnieuw in het huwelijk treedt. ${ }^{44}$ Wanneer de langstlevende overlijdt worden deze goederen erfrechtelijk verkregen door de nieuwe echtgenoot, bij wiens overlijden de kinderen uit het worige huwelijk volgens de wet geen erfgenamen zijn. Op deze manier worden goederen van de erflater uit het zicht van diens kinderen gebracht. De wilsrechten bieden de kinderen de mogelijkheid goederen uit de nalatenschap of de ontbonden huwelijksgemeenschap ${ }^{45}$ te vetkrijgen ter voldoening van de hen toebedeelde vordering van artikel $4: 13$ lid 3.46 Het erfrecht geeft vier situaties in vier afzonderlijke artikelen waarin de kinderen hun wilsrecht kunnen ${ }^{47}$ uitoefenen. De gevallen zijn evenwel bij uiterste wil door de erflater wit te breiden, te beperken en zelfs op te heffen. ${ }^{48}$ In twee van de vier wilstechten is de uitoefening afhankelijk van een onopeisbare vordering van de kinderen. Om de balans tussen de belangen van de langstlevende en de kinderen te behouden wordt de langstlevende de mogelijkheid geboden de goederen over te dragen onder voorbehoud van een recht van vruchtgebruik. ${ }^{49}$

\subsubsection{Het testamentair erfrecht}

Hoewel de testeerwijheid van de erflater nog inmer voorop staat, heeft de wetgever duidelijk de grenzen van deze vrijheid aangegeven. Weliswaar is de erflater gerechtigd de wettelijke verdeling geheel buiten werking te stellen ${ }^{50}$, de manier waarop de erflater zijn uiterste wilsbeschikking vorm wenst te geven is aan een aantal beperkingen onderworpen. Vooreerst is de afdeling "Andere wettelijke rechten" van dwingend recht. ${ }^{51}$ Ten behoeve van de langstlevende zijn daarin achtereenvolgens het recht van voortgezet gebruik en bewoning ${ }^{52}$, het recht van vruchtgebruik van de echtelijke

44. Darnast speelt het stieffamilie-gevar bijvoorbeeld ook wanneer een gescheiden ouder opnicuw in het hawelijk treedt.

45 Zie art. $4: 24$.

46 Kamerstukken II $1996-1997,17141$, nr. 21, p. 12 .

47 Er dient hier gesproken te worden wan 'kunen', ondat de kinderen niet gehouden zijn de wilsrechten wit te oefenen. Zij kuminen er voor kiezen miet of met meteen gebruik te maken van deze whsteehter.

48 Art 4:25 lid 6. VMN Molknk tmerkt terecht op dat de erfater "de verplichtingen" (van de langstevende) kan witbreiden, beperken of opheffen. Zulks houdt immers inet in dat 'de rechten' (vaft de kinderen) kumen worden witgebreid enzowoorts. Dat het cen volgt wit het ander doet daar niet aan at. Mif radt de notaris an zijn bewoordingen voor het testament zorgvuldig te kiezen. Handboek Nieny Enfrecht (2002), p. 75-76. Deze mogelijklteid tot het wijzigen van de wilsrechten ontlokt aan: VAN DeR BUACHY en EBBIN de opmerking dat de wilsrechten (enigszins gechargeerd) op drijfizand zajn gebouwd. Or. van der Burglit an E. WI. Ebben, WPNR 6350 (1999), p. 215 .

49 Arr. $4: 19$ en 21 laatste zin.

50. Art. 4: 13 bevat de bijzin: '(..), tenzij de erfater bij unterste whsbeschikking heeft bepaald dat deze afoling gehed buiten toepassing blijft, $(\ldots)^{\text {" }}$.

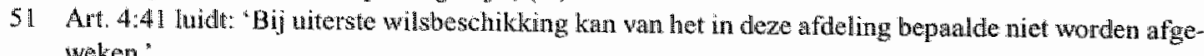
weken.

52 Art. $4: 28$. 
woning ${ }^{53}$ en het verzorgingsvruchtgebruik ${ }^{54}$ geïntroduceerd. Deze rechten zijn vanwege het dwingendrechtelijke karakter van de afdeling tot op zekere hoogte onaantastbaar. ${ }^{55}$

Ten tweede heeft de wetgever een gesloten stelsel van uiterste wilsbeschikkingen in het erfrecht vastgelegd. ${ }^{56}$ De erflater kan in zijn uiterste wil drie beschikkingsvormen $^{57}$ hanteren, te weten de erfstelling ${ }^{58}$, het legaat ${ }^{59}$ en de testamentaire last ${ }^{60}$. De erfstelling houdt in dat de erflater, bijvoorbeeld naast zijn eventuele versterferfgenamen, een (rechts)persoon tot erfgenaam kan maken. De rechtspositie van deze testamentaire erfgenaam is mutatis mutandis hetzelfde als die van de versterferfgenaam. ${ }^{61}$ Het legaat is een uiterste wilsbeschikking waarin de erflater aan een of meer personen een vorderingsrecht toekent. De verkrijging van dit vorderingsrecht is onder bijzondere titel ${ }^{62}$ De gerechtigde tot dit vorderingsrecht noemt men de legataris. De testamentaire last is een bij uiterste wil aan erfgenamen of legatarissen opgelegde verplichting niet zijnde een legaat. ${ }^{63}$ Tot slot dient de erflater rekening houden met de legitieme portie van zijn erfgenamen. De wetgever heeft de legitieme portie in het nieuwe erfrecht gehandhaafd, zij het dat 'slechts' een vordering in geld is overgebleven. ${ }^{64}$ Niettemin levert de hand-having van de legitieme een wettelijke beperking (in geld) van de testamentaire vrijheid op voor de erflater ter hoogte van de vordering van de legitimaris. Daarbij dient te worden aangetekend dat de legitimaris wel een beroep moet doen op zijn legitieme om de vordering in het leven te roepen. Bo-

53 Art. 4:29.

54. Art. $4: 30$.

55 Deze onaantastbaarheid verleidt VAN MoukIK tot de opmerking dat deze rechten 'van legitimaire aard' zijn. Het adjectief werwijst naar de legitieme portie, ook wel het wettelijk erfdeel genoemd. welke een lange geschiedenis kent en bepald controversieel is (zie noot 8 ). Handboek Nieuw Erfrecht (2002), p. 362.

56 Art. 4:42. In het artikel staat dat een erflater enkel een beschikking kan maken ' (...) die in dit Boek is geregeld of in de wet als zodanig wordlt aangemerkt. "Voor een overzicht van de beschikkingen buiten Boek 4 werwijs ik naar Asser/Perrick 6.A (2002), ni. 107.

57 Overigens vormt dit drietal geen uitputtende opsomming. Naast de te nomen beschikkingswornen walt immer ook te denken aan de benoenting van een executeur (ex artikel 4:142) of het opnemen wan cen uitsluitingsclausule.

58 Art. 4:115.

59 Art. 4:117.

60 Art. $4: 130$.

61 Zulks blijkt uit de bepaling van art. 4:116. Dit houdt overigens niet in dat de testamentaire erfgenaam gelijk is aan de versterferfgenaam. $Z$ o is in het geval van een erfstelling geen sprake van plats. wervulling. Art. 4:12. Vergelijk Handboek Nieuw Erfrecht (2002), p. 40.

62 Handboek Nieuw Erfrecht (2002), p. 129. Dit geldt eveneens indien de legataris een erfgenaam betreft. Men spreekt in dat gewal overigens ook wel wan een prelegat.

63 Zie voor een bespreking van het schemergebied tussen last en legat. Handboek Nienw Erfrecht (2002), p. 131; Asser/Permick 6A (2002), nr: 119.

64. Het reduceren van de legitieme portie tot een vordering in geld wordt in de notariêle praktijk ook wel "uitboedelen" genoemd. 
vendien wordt deze vordering verminderd met eventuele giften aan de legitimaris ${ }^{65}$ alsook met de waarde van hetgeen de legitimaris krachtens erfrecht verkrijgt of kan verkrijgen $^{66}$.

Verderop in dit hoofdstuk ${ }^{67}$ behandel ik het vruchtgebruk dat door middel van een legaat wordt vemaakt. ${ }^{8}$

\subsection{Het voorbehouden vruchtgebruik bij uitoefening van wilsrechten}

\subsection{De wilsrechten: inleiding}

Een wilsrecht houdt in dat een kind de langstlevende kan verplichten goederen uit de nalatenschap of de ontbonden huwelijksgemeenschap aan hem of haar over te dragen zulks ter voldoening van de vordering van artikel $4: 13$ lid 3 . Het doel van het wilsrecht is tweeledig. Enerzijds biedt het de kinderen de mogelijkheid het stieffamiliegevaar rechtstreeks te bestrijden, namelijk door goederen uit de nalatenschap of ontbonden huwelijksgemeenschap van de ouders te verkrijgen. ${ }^{69}$ Anderzijds wordt op deze manier de kinderen een vorm van zekerheid voor hun erfiechtelijke vordering geboden. ${ }^{70}$ De wilsrechten zijn verbonden aan de persoon ${ }^{71}$, dat wil zeggen aan het kind, en niet aan de vordering. Draagt het kind de vordering op de langstlevende over aan een derde dan gaat het wilsrecht teniet. ${ }^{72}$ In beginsel is de uitoefening niet aan een termijn gebonden, degenen die tot overdracht verplicht kan worden kan evenwel een redelijke termijn stellen, zodra de kinderen het recht hebben een dergelijk wilsrecht uit te oefenen. ${ }^{73}$ Er zijn zoals reeds vermeld vier situaties waarin een kind een beroep kan doen op zijn of haar wilsrecht.

65 A.s: $4: 70$

66 Art: $4: 71$

672 Zive 3.6 .2 .

68 Howwel een recht wan vruchtgebruik ter uitvoering wan een last eveneens denkbaar is, hat ik deze constructie vender buiten beschouwing. De problematick rond dit wraagstuk komt vrijwel overeen net het legat.

69 Ovengens is de verkrijging ean werkrijging krachtens enfrecht. Kamerstukken II $1996-1997,17$ 141 , n: 21 , p. 16. Handboek Nieuw Erfredt (2002), Asser/Perrick 6A (2002), nr, 62; C.A. Kraan, in: "Preadvies Fuchtgebruik KNB" (1999), p. 81.

70 Dit duale katalktter van thet doel van wilsrechten walt op te maken uñt Kamerstukken $L 1997$ - 1998, $17 \llbracket 41$, nu. $25,0.10-11$.

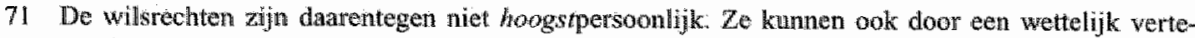
genwoordiger worden uitgeoefend. Kamerstukken $/ / 1997-1998,17141$, nr: 25, p. 10 .

72 Art. $4: 25$ lid 5

73 Art. $5: 25$ lid 3. 
Schematisch weergegeven gaat het om de volgende vier gevallen:

\section{Wilsrecht ex artikel $4: 19^{74}$}
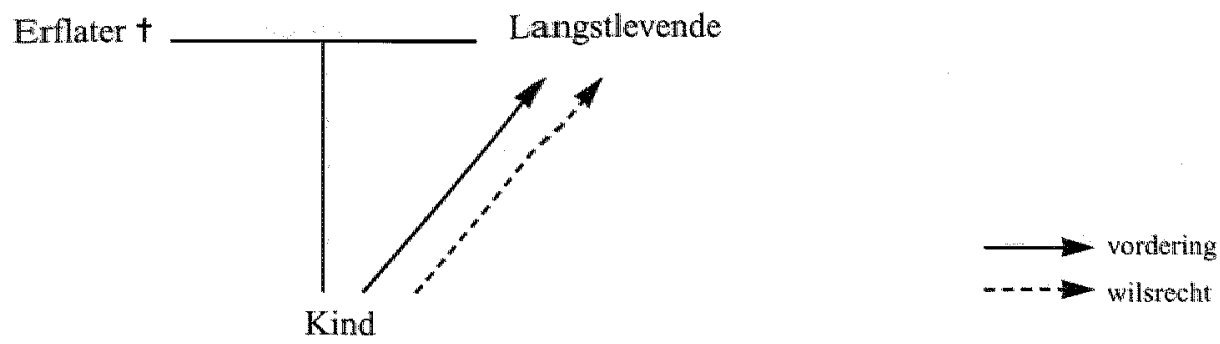

\section{Toelichting artikel 4:19}

Wanneer de langstlevende na overlijden van de erflater opnieuw in het huwelijk wenst te treden dient hij of zij hiervan - zoals voor ieder huwelijk dat vereist dat aangifte te doen. ${ }^{75}$ Deze aangifte voor het huwelijk schakelt het eerste wilsrecht van de kinderen in, dat zoals gezegd samenhangt met de onopeisbare vordering van de laatsten jegens de langstlevende. Zij kunnen voor de aanstaande huwelijksluiting en ook daarna verzoeken om overdracht van goederen uit de nalatenschap van de eerst overleden ouder of uit de ontbonden huwelijksgemeenschap.

\section{Wilsrecht ex artikel $4: 20$}

Erflater $\dagger$ Langstlevende $\dagger$ Stiefouder

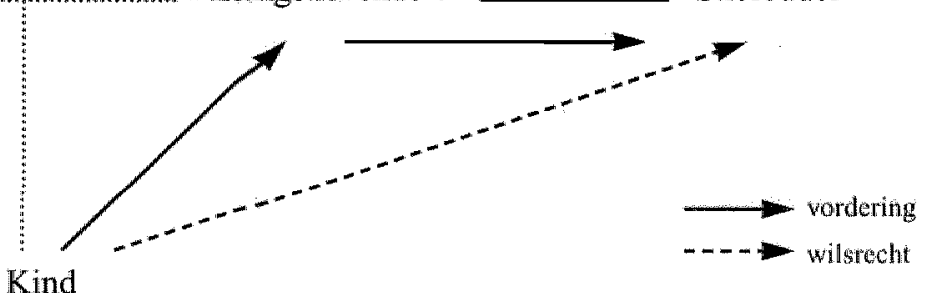

\section{Toelichting artikel 4:20}

Op het moment dat ook de langstlevende overlijdt, verkrijgt de stiefouder als onderdeel van de nalatenschap de schuld van de langstlevende jegens het kind. De vorde-

74 In verband met het aan dit artikel - alsmede aan art. 4:21 - gekoppelde vruchtgebruik wondt in de literatuur ook wel gesproken wan het eerste en weede 'blooteigendoms-wilsrecht' (Handboek Nicuw Erfirecht (2002), p. 78-79; Ebhen, disis, P. 45 en 51; W. Burgerhart, WPNR 6424 (2000), p. 827 en verder). Het teit dat het whuhtgebruik ook op vermogenstechten kan worden gevestigd, weerhoudt mij ervan de benaming over te nemen. Zie tevens 82.1 .1 . Art 1:43 lid 1 . 
ring die aan deze schuld ten grondslag ligt is door het overlijden van de langstlevende opeisbaar geworden. Ter voldoening van deze vordering kunnen goederen uit de nalatenschap van de langstlevende of van de voor diens overlijden ontbonden huwelijksgemeenschap worden overgedragen.

\section{Wilsrecht ex artikel $4: 21$}

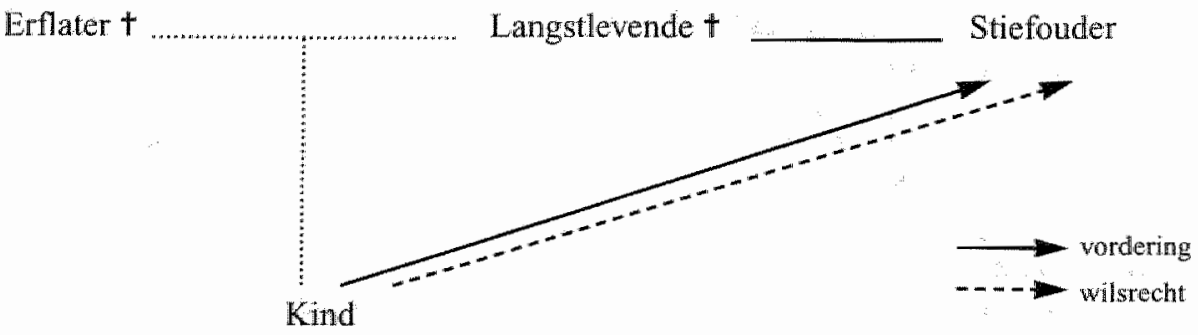

\section{Toelichting artikel 4.21}

Naast de opeisbare vordering op de stiefouder ontstaat door het overlijden van de langstlevende tevens een onopeisbare vordering op de stiefouder van het kind. Deze vordering verkrijgt het kind als erfgenaam van de langstlevende - nu tevens erflater - op de stiefouder die zijn beurt de langstlevende is tit het tweede huwelijk. Deze situatie is in die zin vergelijkbaar met de situatie van het wilsrecht 4:19 en wordt voor de stiefouder aldus vergezeld van de mogelijkheid tot het voorbehouden van het recht van vruchtgebruik. Goederen van de zijde van de stiefouder die in de nieuwe hurvelijksgemeenschap vallen, zijn uitdrukkelijk uitgesloten voor wat betreft de uitoefening van het wilsrecht. ${ }^{76}$

\section{Wilsrecht ex artikel $4: 22$}

Erflater + Langstlevende +

Stiefouder
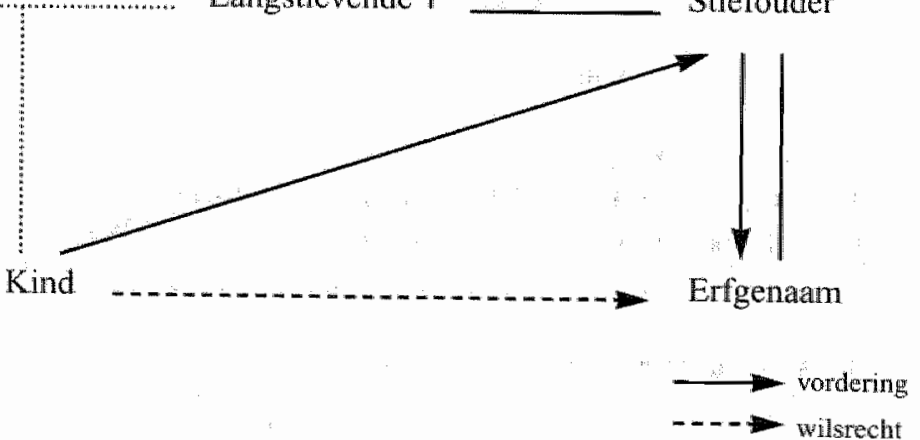

76 Art $4: 24$ lid 1 slotzin. 


\section{Toelichting artikel $4: 22$}

Het laatste wilsrecht ontstaat wanneer de stiefouder overlijdt. De onopeisbare vordering die de kinderen krachtens erfrecht wan de langstlevende hebben gekregen is door het overlijden van de stiefouder opeisbaar geworden. De erfgenaam van de stiefouder verkrijgt deze schuld als onderdeel van de nalatenschap van de stiefouder. Jegens deze erfgenaam kan het kind uit het eerste huwelijk het laatste wilsrecht uitoefenen ten aanzien van de nu opeisbare vordering voor wat betreft goederen uit de nalatenschap van de langstlevende. Wederom zij vermeld dat de goederen van de zijde van de stiefouder uit de (ontbonden) huwelijksgemeenschap van de langstlevende en de stiefouder buiten het bereik van het wilsrecht wallen. ${ }^{77}$

\subsubsection{De goederen}

Hoewel helder is dat kinderen op grond van de wilsrechten de langstlevende kunnen verplichten goederen over te dragen ${ }^{78}$, is daarmee niet de vraag beantwoord wélke goederen moeten worden overgedragen en/of wie deze goederen aanwijst. De wet biedt in dit kader slechts enkele parameters. Voor wat betreft de eerste vraag geldt on te beginnen dat enkel goederen die behoren tot de nalatenschap of de ontbonden huwelijksgemeenschap ${ }^{79}$ of hetgeen daarvoor in de plaats is gekomen ${ }^{80}$ in aanmerking komen. ${ }^{81}$ In beginsel is geen enkel goed uit deze categorie uitgesloten wan verplichte overdracht. Het nominale bedrag van de vordering, vermeerderd met de eventuele verhoging is bepalend voor de vraag met betrekking tot welke goederen om overdracht verzocht kan worden. ${ }^{82}$ Woor het overige valt aan te nemen dat het verzoeken om de overdracht van de goederen niet in strijd mag zijn met het doel dat met de wilsrechten wordt beoogd. Leidend motief voor toekenning van de wilsrechten is het behoud van goederen uit de nallatenschap of ontbonden huwelijksgemeenschap ten behoeve van de kinderen, waardoor aldus het stieffamilie-gevaar het hoofd wordt geboden. Het onderliggende dualle karakter zorgt echter ook voor verwarring. VAN

77 Art. $4: 24$ lid 1 slotzin.

78 Aangetekend dient te worden dat in de wetsgeschiedenis ook gespoken wordt van "cen rech on overdracht van goederen" hetgeen naar mijn swatk beter aftwingbat klinkt dan de hier genoende phicht. Aangezien de betrokken wetsartikelet spreken wan plicht zal ik deze weergave aanhouden.

79 Voor zover zj niet op grond van artikel 4:24 lid I slotzin zijn thitgezonderd.

80 De kinderen worden in het kader wan deze substitutietegel bijgestata door het bewilswemoeden opgenomen in art $4: 24$ lid 3 . Het gaat er wan wit dat alk goed dat to het vermogen of de huwelijksgemeenschap wan de overdrachtsplichige behoort, vermoed wordt tot de nalatenschap of ontbondkn huwelijksgemeenschap te behoren. Voor werdere bespreking van deze regel van substintic un zijn problemen verwijs ik naar Handbock Nieuw Erftecht (2002), V.5.

81 Art. 4:24 lid 1 .

82. Art. 4:19 th 4:22, alsmede voor de war debepaling art. 4:25 lid 1. Oversehrijdt de warde van het goed de waalde van de wordering dan stelt de Mvj voor dat het goed gedeellelijk wordt owergedragen of dat het kind de overwaarde vergoedt. Kantersthken $/ 1$ 1997-1998, n. 27, 13. 22. Kennelijk met instemming Handboek Nieuw Erfrecht (2002), p. 81; Ebben, diss, p. 43. 
Mourik maakt woor wat betreft dit karakter onderscheid tussen het 'affectie-aspect' en het 'zekerheidsaspect'. In de verhouding tussen de twee acht hij het 'affectieaspect' mede bepalend. ${ }^{83}$ Ebben, die hetzelfde onderscheid en dezelfde benaming hanteert, acht het affectie-aspect ondergeschilkt aan het 'zekerheidsaspect. ${ }^{34}$ Naar mijn smaak is echter geen hiërarchie aan te nemen of is het onderscheid op zijn minst niet van essentieel belang. Beide aspecten zijn verschillende zijden van dezelfde munt. De wilsrechten staan ontegenzeggellik ten dienste van het kind en deze veronderstelling is bepalend woor de invulling van de willsrecht-regeling. ${ }^{85}$ Het kind verzoekt orm overdracht van een door hem of haar gekozen goed. De langstlevende kan dit verzoek slechts dan pareren indien zijn belang in dat geval het belang van het kind overvleugelt. De reden kan bijvoorbeeld zijn dat de langstlevende zelf een sterke (familie)band heeft met het goed en/of dat zij zekerheid stelt voor de vorclering op grond waarvan het wilsrecht wordt uitgeoefend ${ }^{86}$ Indien partijen het niet eens worden over of, en zo ja welk goed moet worden overgedragen, dient de rechter genoemde belangenafweging te maken naar maatstaven van redelijkheid en billijkheid. ${ }^{87}$

\subsubsection{Het voorbehouden wruchtgebruik: witzonderingen op titel 3.8}

Van de vorderingen die het kind op de langstlevende of de stiefouder heeft, zijn er twee nog niet opeisbaar. Het betreft de gevallen van artikel 4:19 en 4:21.88 De wetgever heeft in deze gevallen de pijn voor de langstlevende ${ }^{89}$ verzacht. Wanneer gebruik gemaakt wordt van een willsrecht uit een van beide artikelen, dan kan de langstlevende het betreffende goed overdragen onder voorbehoud van een recht van vruchtgebruik. ${ }^{90}$ Op dit vruchtgebruik is de lex specialis van artikel 4:23 van toepassing,

83 Handboek Nieuw Erfrecht (2002), p. 81 .

84 Ebben, diss, p. 53.

85. Ik herhal voor de goede orde de woorden van de MvJ die stelt dat de wilsrechten de kinderen worden geboden om cen 'passend evenwichr' te bereiken in het nieuwe versterferfrecht. Zie noot 41 supra. Een controlerende langstlevende bij uitvoering van het wilsrecht naar regelend recht lijkt mij een verstoring van het beoogde evenwicht. Deze verstoring kan enkel werantwoord worden indien de erflater zich met de verplichtingen van de langstlevende bemoeit. Zulks op grond van art. 4:25 lid 6. zie noot 48 suptr.

86 Aldus de Mw: Kamerstokken $/ I 1997-1998,17141$, nu. 25, p. 10-11.

87 Art. 4:25 lid 4. De Mvl stell overigens dat niet wath te verwachten dat de rechter oordeelt dat er geen enket goed zal worden overgedragen. Ter bescherming wan de langsitevende is immers het voorbehouden vruchtgebruik opgenomen. Kamersfukten $112000-2001,27021$, nr. 5, p. 10 .

88. Respectievelijk de figuren 1 en 3 .

89. Bij wooroverlijden wan de langstlewende wordt de stiefouder op zijn beurt de langstlevende echtgenoot.

90 De wetgever heeft hier wadrukkelijk een keuze voor de langstlevende beoogd. De langstlevende kán het recht van wruchtgebruik voorbehouden. Handboek Nienw Errfecht (2002), p. 85; Ebben, diss., p. 48. Bovendien is thet voorbehonden van dit vruchtgebruk nist aan het vereiste van een verzorgingsbehoefte onderthevig (Kannerstukken // $1997-1998,17141$, nr. 27, p. 22). Deze behoefte speelt, zoals aanstonds zal blijken, wel een rol buj het eventueel witbreiden van de bevoegdheden wark de vruchtgebruiker. 
wat leidt tot uitzonderingen op titel 8 van Boek 3 . Zo is de langst-levende vrijgesteld van het doen van de jaarlijkse opgave en het stellen van zekerheid. ${ }^{9 t}$ Daarenboven zijn in lid 1 sub b en lid 2 van het artikel mogelijkheden opgenomen om, net inschakeling van de kantonrechter door de langstlevende, de beschikkingsbevoegdheid van de vruchtgebruiker-langstlevende op andere gronden uit te breiden dan welke genoemd zijn in artikel 3:212 lid 3 en 3:215. ${ }^{92}$ Een van de gronden voor uitbreiding is specifiek voor het nieuwe erfrecht: de verzorgingsbe-hoefte ${ }^{9.3}$ van de langstlevende. Het belang van de kinderen als hoofdgerechtigden, zoals dat bescherind zou worden op grond van titel 3.8, wordt ondergeschikt gemaakt aan dat van de langstlevende. ${ }^{94}$ De uitbreiding kan tevens plaats vinden, indien dit dienstbaar is aan de verplichting van de langstlevende om de schulden van de nalatenschap te voldoen. ${ }^{95}$

Een tweede opmerkelijke afwijking van het vruchtgebruikregime van Boek 3 is het uitschakelen van de substitutie. ${ }^{96}$ Lid 3 van artikel 4:23 stelt de regeling uit titel 3.8 terzijde en biedt de hoofdgerechtigde bij vervreemding door de vruchtgebruiker slechts een onopeisbare vordering ${ }^{97}$ op de laatste. ${ }^{98}$ Door afwijking van de hoofdregel (substitutie) worden problemen die door de substitutieregeling van artikel 3:213 worden veroorzaakt ${ }^{99}$, omzeild.

Nu de substitutieregel niet van toepassing is voor het voorbehouden vruchtgebruik doemt de vraag op in hoeverre nog onderscheid gemaakt dient te worden tussen de bevoegdheid tot vervreemden ${ }^{100}$ en de bevoegdheid tot vervreemden en verteren ${ }^{10 !}$. Immers, indien de vruchtgebruiker een goed vervreemdt, leidt zulks in beide gevallen tot dezelfde situatie. Ten eerste ontstaat een vordering voor de hoofdgerechtigde jegens de vruchtgebruiker. Ten tweede gaat hetgeen de vruchtgebruiker bij de vervreemding ontvangt tot diens vermogen behoren. Sterker, het is strikt genomen nog

91 Art. 4:23 lid I sub a jo art. 3:205 lid 4 en 3:206 lid 1 en 2. De wetgever vond deze verplichtingen. "te bezwaarlijk" voor de langstlevende. Kamerstukken $/ I 1996-1997,17$ 1.41, nr. 21 , p. 20.

92 Zie voor de bespreking van deze artikelen in algemene, goederenrechtelijke zin respectievelijk $\$ 2.4 .2$ en $\$ 2.4 .3$.

93 Behandeling van de verzorgingstbehoefte windt plats in $\$ 3.5 .3$.

94 Komerstukken II 1996-1997, 17 141, nx. 21, p. 20.

95 Art. 4:23 lid 1 sub b jo art. 4:13 lid 2.

96 Voor de goede orde benadruk ik hier dat, wanneer ik in dit hoofdstuk spreek over substitutie, gedoeld wordt op de goederenrechtelijk substitutie van art. $3: 213$. Deze regeling is in $\$ 2.6$ uitgebreid aan bod geweest. Deze goederenrechtelijke substitutie dient niet verward te worden met de substitutie in het kader wan de wertegenwoordiging (art. 3:64) of de zogenaande 'vulgare substitutie' in het erfrecht. Zie over de "vulgaire substitutie" Handboek Nieuw Erfrecht (2002), p. 190.

97 Door gelijkschakeling met art. 4:13 lid 3 en 4 heeft deze vordering dezelfde kenmerken als de vordering die de kinderen door de wettelijke verdeling op de langstievende ontwangen.

98. Dit geldt zowel voor vervreemdling krachtens de machtiging van de kantonrechter (art.4:23 lid 1 sub b), als bij het eventueel verkregen recht van vervreemding en vertering van art. 4.23 lid 2 . Kannerstukken II 1997-1998, 17 141, nr. 26, p. 12. Van deze regel kan blijkens het artikel evenwell contractueel worden afgeweken.

99 Zie $\$ 2.6$.

100 Ex art. $4: 23$ lid 1 sub b.

101 Art. $4: 23$ lid 2. 
onjuist te spreken van vruchtgebruiker en hoofdgerechtigde omdat de vervreemding door de vrichtgebruiker en het uitblijven van substitutie leidt tot het einde van het vruchtgebruik. Daarvoor in plaats komt een schuldenaar (voorheen vruchtgebruiker) - schuldeiser (voorheen hoofdgerechtigde) verhouding.

Het benadrukken van het onderscheid tussen vervreemden enerzijds en vervreemden en verteren anderzijds blifft naar mijn smaak niettemin gerechtvaardigd. De bevoegdheid wan wervreending en werteren gaat, ondanks de hierboven geschetste vervaging vah de grens, verder dan de vervreemding met machtiging uit artikel 4:23 lid 1 sub b. Uit de Parlementaire Geschiedenis blijkt dat de wetgever een vergoeding van verteerde goederen niet meer dan billijk acht. ${ }^{102}$ Mijns inziens is zulks in strijd met de ratio van de bevoegdheid tot wervreemden en verteren: Analoge toepassing van artikel 3:215 lid 1 betekent dat de bevoegdheid tot vervreending en vertering ertoe leidt dat de vruchtgebruiker niét gehouden is de hoofdgerechtigde(n) te compenseren indien hij of zij kan aantonen dat het litigieuze bezwaarde goed verteerd is ${ }^{103} \mathrm{Ik}$ zou dan ook met VAN MOURrKK ${ }^{104}$ menen dat de vergoedingsvordering dienovereenkomstig dient te worden verkleind. ${ }^{105}$ De rechtsgrond voor een zelfstandig bestaan van lid 2 van artikel $4: 23$ is daarmee gegeven. De uitgebreide verteringsbevoegdheid vertaalt zich in een afwaardering van de vergoedingsvordering, daar waar deze vordering bij enkele vervreending in stand blijft. Dit veronderstelt eehter wel een goederenrechtelijke band tussen het door de vruehtgebruiker verkregen goed en de aan de hoofdgerechtigde toebedeelde vordering. Een band die niet noodzakelijkerwijs bestaat. ${ }^{106}$ Mocht een en ander goederenrechtelijk niet houdbaar blijken dan is hier naar mijn smaak een anticiperende rol voor de rechter weggelegd. De kantonrechter is immers bevoegd bij zijn beschikking nadere regelingen te treffen op grond van artikel 4:23 lid 2 slotzin:

Ten slotte legt het artikel ook een beperking op de bevoegdheden van de vruchtgebruiker. De langstlevende is, in tegenstelling tot de regel uit artikel 3:223, niet bevoegd over het vruchtgebruik zelf te beschikken, hetgeen natuurlijk strookt met het achterliggende motief voor toekenning van het recht van vruchtgebruik. ${ }^{107}$ De regel doet, gezien het voorafgaande, enigszins vreemd aan mu bij bevoegde vervreemding door de vruchtgebruiker door het ontbreken van substitutie feitelijk over het vruchtgebruik wordt beschikt. Worden de bezwaarde goederen vervreemd dan gaat het vruchtgebruik alsnog door beschikking door de vruchtgebruiker teniet.

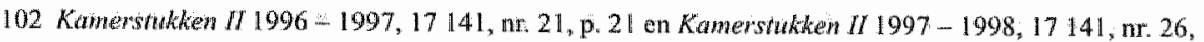
p. 12

103 Zie tevens 8.2 .4 .4 .4

104 Handboek Nienw Erfrech (2002), p. 86.

105 Anders: uitarkkelijk Ebben, diss. p. 102 en kemeligk ook C.A. Kraan, in: "preadvies Wrachrgebraik KNB (1999), p. 86 en Van Gaalen, diss., nr. 074.

106 PERRICK conchadeart door afwezigheid wan de goederentechtelijke verhouding tot een gelijkstelwing in deze van de vervreending op grond van rechtenlijke machtiging met de bevoegdheid tot vervreending en vertering. Hij betwiffelt dan ook de roegevoegde waarde van het tweede lid wan art. 4:23. Asser Perrick 6A (2002), nr. 96.

107 Aldus ook Kamerstuken II 1996-1997, 1.7 141, nr. 21, p. 21. 


\subsubsection{Het voorbehouden wruchtgebruik ap aandelen ex artikel $4: 19$ en 4:21}

Uit de voorafgaande paragrafen kan met recht geconcludeerd worden dat elk goed uit de nalatenschap, ontbonden huwelijksgemeenschap of zelfs een goed dat daarvoor in de plaats is getreden, in potentie kan worden geraakt door de uitoefening van een wilsrecht. Naar mijn smaak zal daarom niets een van de kinderen beletten zijn of haar wilsrecht uit te oefenen op een aandeel in een kapitaalvennootschap. Een aandeel in een kapitaalvennootschap is op geld waardeerbaar en kan in waarde stijgen. Aangetekend moet evenwel worden dat het risico van waardedaling prominenter aamwezig is dan bij andere goederen. Een voorbehouden vruchtgebruik op een aandeel in een kapitaalvennootschap is voorstelbaar. Het enkele feit dat ten behoeve van deze eventualiteit een wijziging van de lex specialis van de artikelen 2:88 en 2:197 heeft plaatsgevonden ${ }^{108}$, moge getuige zijn wan deze mogelijkheid.

Mocht er onenigheid bestaan over het aandeel als gekozen goed in het kader van de wilsrechten, zal een belangenafweging door de rechter plaatsvinden. Daarbij dient opgemerkt te worden dat, zo de 'affectie' een rol gaat spelen bij de te hanteren redelijkheid en billijkheid, het mijns inziens niet ondenkbaar is dat dit aspect ook bij aandelen in een kapitaalvennootschap aanwezig is. Men denke daarbij vooral aan die aandelen waarbij het betrokken aandeelhouderschap ${ }^{109}$ een belangrijke rol speelt, zoals bij de BV. ${ }^{10}$ Overigens zij in dit kader tevens opgemerkt dat de wetgever de uitoefening van een wilsrecht op een tegoed bij een bank kennelijk niet ondenkbaar acht" ${ }^{11}$, hetgeen de 'affectie-eis' naar mijn smaak enigszins relativeert.

\subsection{Het verzorgingsvruchtgebruik}

\subsubsection{Inleiding}

In het nieuwe erfrecht is ruim aandacht besteed aan de vrijheid van de erflater om naar eigen inzicht te beschikken over de nalatenschap. De testeervrijheid wordt,

108 In afwijking van de hoofdregel uit de att. 2.88 en $2: 197$ is het de wruchtgebruike die in beginsel het stemrecht op het betrokken aandecl in ech kapitalvennootschap mag thitoefenen. Deze towenning achtte de wetgever gepast, angezicn de langstlevende ook wat het aandeel betreft in stagl gesteld diende te worden 'zoveel mogelijk voort the lewen als voorheen'. Kamerstukten $1 / 1999-2000,27$ 245, mr. 3, p. 4. "Voorheen" was de langstlevende naturlijk door de wettelijke verteling (onbezward) atandeelhouder, rnits darbij niet in de weg gestagin door een erfrechtelijke blokkade zie hierna in $\$ 3.7$.

109 Voor een verdere bespreking van de aard wan en alandeel verwijs ik naar $\$ 5.2$.

$110 \mathrm{In} 83.4$ wordt verder ingegann op de rol wan het vrichtgebruik bij vererving van aandelen. Bijzondere aandacht zal daatbij worden gegeven aan blokkeringstegelingen.

111 Komerstuken II $1997-1998,17141$, nr. 26, p. 12. 
behalve door de goede zeden en de openbare orde ${ }^{1 / 2}$, begrensd door de wet. ${ }^{1 / 3}$ Het gesloten stelsel en de dwingendrechtelijke afdeling van de 'Andere wettelijke rechten" ${ }^{\prime \| 4}$ geven de grenzen van de testeervrijheid aan. Een van de rechten uit deze afdeling is het verzorgingsvruchtgebruik ex artikel 4:30. De langstlevende kan op grond van deze bepaling van rechthebbenden ${ }^{15}$ op goederen uit de nalatenschap verlangen dat zij meewerken aan het vestigen van een recht van wruchtgebruik op de door de langstlevende aan te wijzen goederen. Het vrucht-gebruik dient ter verzorging van de langstlevende en de behoefte tot verzorging speelt dientengevolge een bepalende rol voor de vraag op welke goederen het beperkte recht wordt gevestigd.

\subsubsection{De keuzewrijheid ten aanzien van de goederen}

De wet geeft aan uit welke goederen de langstlevende mag kiezen voor de vestiging van het verzorgingsvruchtgebruik. Ten eerste spreekt de wet van 'andere goederen dan de goederen bedoeld in artikel 4:29'. Dit laatste artikel biedt de langstlevende de mogelijkheid een vruchtgebruik te vestigen op de echtelijke woning en de inboedel. Indien over de goederen uit de nalatenschap wordt beschikt, vindt substitutie plaats. ${ }^{16}$ Ten tweede bepaalt lid 5 van artikel 4:30 dat goederen die krachtens legaat of testamentaire last verkregen zijn pas mogen worden bezwaard indien de overige goederen niet in voldoende mate verzorging bieden. ${ }^{17}$ Zelfs de vorderingen van de kinderen kunnen, wanneer zij opeisbaar worden, ter verzorging worden bezwaard. ${ }^{118}$ Daarenboven kan de erflater die een beroep op het verzorgingsvruchtgebruik voorziet in zijn uiterste wilsbeschikking goederen aanwijzen welke voor het verzorgingsvruchtgebruik in aanmerking komen. ${ }^{119}$ Gezien het doel van de bepaling moet geconcludeerd worden dat goederen die niét bijdragen tot de verzorging van de langstlevende niet in aanmerking komen voor bezwaring. Een bezwaring die het hoofdrecht beperkt zonder bij te dragen aan de verzorging van de langstlevende druist immers in tegen het wezen van de regeling. Met inachtneming van het voorgaande is de langstlevende naar mijn smaak voor het overige vrij on goederen uit te kiezen voor het verzorgingsvruchtgebruik. Ontstaat op enig moment onenigheid over het te bezwaren goed dan is het wederom aan de kantonrechter om, naar maatstaven van redelijkheid en billijkheid, uitkomst te bieden. ${ }^{40}$

112. Art. 4:44.

113. Zie $\$ 2.1 .2$

114 Afdeling 2 boek 4.

115 Dit is ruimer dan erfgeiamen. Ook legatarissen kumen op grond van art. 4:30 worden aangesproken. Zie noot 117 infra.

116 Openingszin art. 4:30 lid 2 .

117 Datt ook lasibevoordeelden en legatarissen kumen worden geconfronteerd met het recht tot bezwaring van de hen toebedeelde goederen blijkt expliciet uit lid 3 van art. 4:30.

118 Art. $4: 30$ lid 2

119 Ant 430 lid 4

120 Aldus lid 6 van art. 4:30. 


\subsubsection{De verzorgingsbehoefte}

Om de rechthebbende van het gekozen goed aan te kunnen spreken met de vordering tot het vestigen van een recht van vruchtgebruik, moet de langstlevende aantonen dat zijn verzorgingsbehoefte zodanig groot is dat een aanvullend recht van vruchtgebruik nodig is. Aanvankelijk werd de verzorgingsbehoefte van de zijde van de wetgever niet nader ingevuld. Dit leidde tot vragen in de Eerste Kamer ${ }^{121}$ waarna de Minister van Justitie de mogelijkheid te baat nam om onduidelijkheid omtrent deze kwestie op te helderen. De Minister stelt dat 'de verzorgingsbehoefte ex artikel 4:30' een andere is dan de term die op grond van verzorgingstestamenten door de rechtspraak is ontwikkeld en mitsdien moet zij beperkter worden nitgelegd. Het houdt met name niet in dat de langstlevende zonder meer aanspraak kan maken op hetzelfde leefpatroon als voorheen. ${ }^{122}$ Sterker nog, een stap terug mag van de langstlevende verwacht worden. ${ }^{123}$ De wettelijke maatstaven voor het onderhoud van gewezen echtgenoten kan een oriëntatiepunt vormen. Daarmee stapt de wetgever af van het 'ongestoord voortleven' van de langstlevende voor wat betreft het verzorgingsvruchtgebruik. Mat deze nuancering introduceerde de wetgever echter ook een tweedeling in. 'de verzorgingsbehoefte in het nieuwe erfrecht'. Aan de ene kant de zojuist genoemde verzorgingsbehoefte als criterium woor het werzorgingsvruchtgebruik en aan de andere kant het uitgebreidere verzorgingsmotief zoals dat zijn weerslag heeft gekregen in het versterferfrecht (Afdeling 1 van Boek 4). Het laatste criterium behoudt meer van de oorspronkelijke gedachte die bij de behoefte werd geformuleerd: het ongestoord voortleven. De verzorging van de wettelijke verdeling richt zich met name op het zoveel mogelijk 'in de spullen blijven' van de langstlevende, ${ }^{24}$ terwijl de verzorgingsbehoefte wan afdeling 2 ('Andere wettelijke rechten') veeleer voorziet in een financiële minimumverzorging wan de langstlevende, geënt op de gedachte van verzorging na echtscheiding. Zoals uit de volgende paragraaf zal blijken, kunnen wijzigingen in omstandigheden leiden tot wijziging van de inhoud van het wruchtgebruik.

121 Kamerstukken I1998-1999, 17141 , nr. 120, p. 2 en 6.

122 Kamerstwkken I $1998-1999$, nir. $120 \mathrm{a}$, p. 3-4. Zie voon een bespreking L.C.A. Verstappen, WPNR 6349 (1999), p. 190.

133 Kanterstukkers If 1999-2000, 27021 , mir. 3, p. 10.

124 Deze tweedeling in de werzorging kwan owerigens ook bowendrijwen in en kote - en felle: discussie tussen ZWANKKES en VAN MOURK. De eerste betoogde - onder andere - dat de verzorging van de langstlevende thuishoort in Boek I samen met de verzorging na echtscheiding. VAN Mour HK repliceerde dat de verzorging bij overlijden een extra dimensie in zich draagt namelijk het 'in de spullen bliven". Zie respectievelijk G.G. Zwanikken, WPNR 6169 (1995), p. 121 en M.J.A. van Mourik, WPNR 6170 (1995), p. 146. De ironie wil dat beide standpunten uiteindelijk in het nieuwe erfrecht zijin samengesmolten. 


\subsubsection{Het verzorgingswruchtgebruik: de artikelen $4: 31$ en $4: 33$}

Het verzorgingsvruchtgebruik kent, naast de van overeenkomstige toepassing verklaarde leden van artikel $4: 23^{125}$, een aantal eigen artikelen voor wat betreft de invulling van het vruchtgebruik. ${ }^{25}$ Twee specifieke artikelen behoeven nadere aandacht: Artikel 4:31 richt zich, in aanvulling op de zo-even genoemde verwijzing naar artikel 4:23, op de formele aspecten van de uitoefening van het recht op vruchtgebruik. De vordering tot vestiging van het recht van vruchtgebruik dient uiterlijk binnen een jaar na overlijden van de erflater te worden ingesteld. ${ }^{127}$ Artikel $4: 33$ is in zekere zin te beschouwen als de geschillenregeling voor het verzorgings-vruchtgebruik. De hoofdgerechtigde kan, met medewerking van de kantorechter, de inhoud van de rechtsverhouding tussen hem en de vruchtgebruiker wijzigen of zelfs het vruchtgebruik beëindigen.

Het eerste lid wan artikel 4:33 opent deze mogelijkheid:

'(...)mits, daardoor een zwaarwegend belang van deze [de hoofdgereclutigde, $E C B]$ wordt gediend en in vergelijking hiermede het belang van de echtgenoot [de vruchtgebruiker] niet ernstig wordt geschaad.:128

De kantonrechter kan bovendien op verzoek van de rechthebbende voorkomen dat het vruchtgebruik wordt gevestigd ${ }^{129}$ of het reeds gevestigde vruchtgebruik beëindigen ${ }^{1130}$, indien de rechthebbende aantoont dat er geen verzorgingsbehoefte is die het vruchtgebruik op het betrokken goed rechtvaardigt.

125 Art. 4:30 lid 1 verwijst naar de leden 1, 2, 4 en 5. Lid 3 welke een uitzondering maakt op de substitutieregell val art. $3: 213$ is darentegen niet van toepassing verklaard, hetgeen een (her-) inschakeling van de genoende substitutieregel van Boek 3 betekent.

126 Overigens zijn deze artikelen tevens gerricht op het recht van vruchtgebruik wan de echtelijke woning ex art. 4:29. Mutatis mutandis gelden de te bespreken regels dus ook voor dit vruchtgebruik. Inhoudelijke bespreking van dit secht valt echter buiten het bestek van dit proefschrift.

127 Art. 4:31 lid 2. Voor het wruchtgebruik van de echteljike woning geldt een termijn van 6 maanden. Interessant is hierbij op te merken dat wat voor wat betreft de echtelijke waning de erfgenamen ingevoige art $4: 29$ lid 2 gedurende deze termijn niét beschikkingsbevoegd zijn ten aanzien wan het goed. Art. 4:30 kent dawentegen géen beperking van de beschikkingsbevoegdheid van de erfgenamen.

128 Preciezer gezegd kan de hoofdgerechtigde het goed (bezwaard) toebedeeld krijgen (sub al), het vruchtgebruik beëindigen (sub b) of de bevoegotheden beperken of ontzeggen (sub c), of het vruchtgebruik onder bewind stellen (sub d).

129 Art $4: 33$ lid 2 sub a Zulks op verzoek wan een rechthebbende wiens goed ingevolge artikel 4:30 in potentie met een recht wat wruchtgebruik kan worden bezwaard. Bovendien bepaalt lid 3 van art. $4: 33$ dat de reclithebbende dit recht allen tijde als tegenwerping kan gebruiken indien van hem of haar verlangd wordt mee te werken an de vestiging van een recht van vruchtgebruik.

$130 \mathrm{Art} .4: 33$ lid 2. Het verzoek dient in dit geval natuurlijk van de hoofdgerechnigde uit te gaan. 


\subsubsection{Het whohigebruik op aandelen ter verzarging}

Howel de invulling van de verzorgingsbehoefte van artikel 4:30 verschilt van de behoefte die gehanteerd wordt voor het voorbehouden vruchtgebruik bij de uitoefening van wilsrechten, is een parallel eenvoudig te trekken. Onderkend moet worden dat het vruchtgebruik op atandelen in zijn algemeenheid in potentie een uitstekende verzorging van de langstlewende kan bieden. Zowel de waarde van het onderliggende goed, de eventuele stijging van deze waarde die door de vruchtgebruiker op grond van een vervreemdingsbevoegdheid te gelde kan worden gemaakt, als ook de periodieke vruchten in de vorm van dividend, maken het aandeel in de kapitaalvennootschap geschikt voor het verzorgingsvruchtgebruik. Voomoemde rechten zijn eclvter wooralsnog alleen in potentie in aanwezig. Mogelijk obstakels in dit kader als de blokkeringstegeling en de uitoefening van stemrecht zullen elders in dit proefschrift worden besproken. ${ }^{131}$

\subsection{Het vruchtgebruik in testamentaire beschikkingen}

\subsubsection{Inleiding}

Uit het voorafgaande kan de conclusie worden getrokken dat de erflater zijn vrijheid tot het vermaken wan zijn goederen onder het nieuwe erfrecht heeft behouden. De vrijheid is niettemin relatief en kent heldere grenzen. Zolang de erllater deze grenzen respecteert, bestaat woor hem of haar bewegingsruimte om de goederen van de nalatenschap naar eigen inzicht te vermaken. Daarbij is het mogelijk, evenals voorheen, het recht van vruchtgebruik in te schakelen. Bovendien heeft de wetgever het wijs geacht de erfrechtelijke en goederen-rechtelijke regels van het vruchtgebruik nauw te betrekken bij de zogenaamde voorwaardelijke making. Op welke manier de regels van vruchtgebruik bij het nieuwe testamentair erfrecht worden betrokken, wordt hierna in 83.4 .3 besproken.

\subsubsection{Het legaat van wruchtgebruik}

Zoals bij de bespreking van het testamentaire erfrecht is opgemerkt, bestaat voor de erflater de mogelijkheid om een recht van vruchtgebruik door middel van een legaat aan een bepaalde persoon te vermaken. Voor wat betreft de wruchtgebruiker die zijn vruchtgebruik krachtens legaat ontvangt, refereer ik mij aan de opmerkingen die bij het legaat onder het oude recht zijn geplaatst. Afgezien van het gewijzigde referen-

13 Voor de vererving wan andelen in de zogenaande "erfrechtelijke blokkade verwijs ik naar \$3.7. De reguliere blokkeringsregeling en het recht van vruchtgebruik alsmede het stemrecht op bezwarde aandelen worden besproken in $\$ 6.21$. 
tiekader van het niewwe erfrecht behouden de daar - in \$3.2. - geplaatste opmerkingen hun gelding. Ook onder het nieuwe erfrecht houdt de conclusie stand dat, wanneer de erflater een recht van vruchtgebruik op een door hem bepaald goed legateert, hij de specifieke rechtspositie ten aanzien van dit goed kennelijk beoogt.

\subsubsection{Woorwatardelijke makingen: onder tijdsbepaling en onder voorwaarde}

Wanneer een notaris een testament opstelt probeert hij zoveel mogelijk de wensen van de testateur te verwerken in de uiterste wil. Niet zelden stelt de erflater het verkrijgen van een bepaald goed krachtens erfrecht afhankelijk van een door hem of haar gecreeerde voorwaarde. ${ }^{132}$ Op deze manier kan over graf of urn theen worden geregeerd. Deze voorwaardelijke makingen vormen ook in het nieuwe erfrecht een bijzonderheid in het testamentaire erfrecht. ${ }^{133}$ De voorwaardelijke making vindt haar oorsprong in het verbintenissenrecht waar de mogelijkheid wordt geschapen om een rechtshandeling onder voorwaarde te verrichten. ${ }^{134}$ Er wordt onderscheid gemaakt tussen de making onder tijdsbepaling en de making onder voorwaarde. Beide betreffen erfrechtelijke verkrijgingen die afhankelijk worden gesteld van een toekomstige gebeurtenis. Wanneer de toekomstige gebeurtenis zeker zal plaatsvinden, hetzij omdat een tijdstip genoemd is hetzij omdat de gebeurtenis onvermijdelijk is, is sprake van een making onder tijdsbepaling. Is het daarentegen onzeker of de gebeurtenis waar de erfstelling afhankelijk van wordt gesteld plaats zal vinden, dan betreft het een making onder voorwaarde. Het nieuwe erfrecht kent bovendien nog een species van het genus 'making onder voorwaarde' namelijk het zogenaamde fideil-commis (de residuo).

\subsubsection{Making onder tijdsbepaling: conversie}

Bij een making onder tijdsbepaling beoogt de erflater persoon A (erfstelling onder ontbindende voorwaarde) een goed te vermaken tot een bepaald tijdstip, waarna vervolgens persoon $B$ (erfstelling onder opschortende voorwaarde) het goed verkrijgt. Zoals vermeld kan de tijdsbepaling zowel een tijdstip zijn - bijvoorbeeld 'tot diens $40^{\text {st }}$ levensjaar' - als een voorwaarde die met zekerheid zal intreden. Het meest gebruikte voorbeeld van dit laatste is 'voor diens leven'. Geheel in lijn met de visie van de wetgever op het gebied van 'tijdelijke eigendomsvormen"135 wordt de bovenstaande rechtsverhouding geconverteerd in een vruchtgebruikver-houding. ${ }^{136}$ Per-

132 Voor alle duidelijkheid; het betreft hier een woorwarde die in vervulling dient te gaan ná overlijden van de erflater.

133 Ondergebracht in een eigen afdeling, te weten afdeling 5 van titel 5 (Onderscheiden soorten van witerste wilsbeschikhingen).

134 Art. 3:38.

135 Art. 3:85. E. B. Rank-Berenschot, in: 'Fan Beheering' (1998), p. 149 en verder.

136 Zulks geldt overigens niet voor legaten onder tijdsbepaling. Wen dergelijke beschikking valt direct onder de werking van artikel 3:85. Kamesstukken II 1962-1963,3771, nr. 6, p. 94-95. Zie hierover Handboek Nieuw Erfrecht (2002), p. 23\%; Asser/Perrick 6A (2002), nr: 161. 
soon B wordt op grond van artikel 4:136 lid 1 krachtens erfstelling met onmiddellijke ingang de hoofdgerechtigde van het goed en hij is belast met een legaat van vruchtgebruik ten behoeve van persoon $\mathrm{A}^{137}$ Om een passend voorbeeld te geven in het kader van dit proefschrift schets ik de volgende casus.

Erflater X heeft zijn aandelen in een vennootschap vermaakt aan zoon A tot het moment waarop zijn zus de leeftijd van 21 jaar heeft bereikt. Daarna verkrijgt zus/ dochter $B$ de aandelen. Artikel 4:136 lid 1 converteert de beschikking aldus dat dochter $B$ hoofdgerechtigde wordt wan de aandelen en dat zij ten behoeve van zoon A een legaat van vruchtgebruik voor de bepaalde tijd dient af te geven voor wat betreft deze aandelen. Voor wat betreft het vruchtgebruikregime moet aangenomen worden dat de hoofdregels van titel 8 van Boek 3 van toepassing zijn.

\subsubsection{Making onder voorwaarde ${ }^{138}$ : van overeenkomstige toepassing}

Wanneer de toekomstige gebeurtenis waar de erfrechtelijke verkrijging van afhankelijk is gesteld onzeker is, betreft het een making onder voorwaarde. Ter verduidelijking een voorbeeld: erflater $X$ vermaakt zijn aandelen in de vennootschap aan zijn zoon $\mathrm{A}$ en vervolgens aan zijn neef $\mathrm{C}$ op het moment dat deze zijn middenstandsdiploma behaalt. ${ }^{139}$ Volgens het wettelijk systeem van artikel 138 lid 1 geidt zoon A bij uitsluiting als rechthebbende onder de zojuist vermelde ontbindende voorwaarde. Neef $\mathrm{C}$ is (slechts) rechthebbende onder opschortende voorwaarde. ${ }^{140}$ Een dergelijke making betekent voor betrokken partijen dat de wettelijke voorschriften woor het vruchtgebruik uit Boek 3 overeenkomstige toepassing vinden. ${ }^{141}$,

137 Art $4: 136$ lid 2 bepaalt dat indien de erflater een erfsteiling onder ontbindende voorwaarde, maar zonder aansiuitende opschortende voorwarde heeft gemalkt, we vruchtgebruiker de vervreendings- en verteringsbevoegdheid van art. 3.215 krijgt toebedeeld. Afgezien van thet "witte raat"gehalte, roept de bepaling tevens een vraag op. Wanneer in mijn voorbeeld de erfstelling ten behoeve van dochter $\mathbf{B}$ ontbreekt, dient de vraag zich aan wie hoofdgerechtiggde is geworden. Naar analogie van art. 4:138 lid 3 moer worden aangenomen dat dit de erfgenamen bij versterf zijn. Zie voor deze conclusie bij art. 4:138 lid 2 Asser/Perrick 6A (2002), nr. 156 .

138 Onder het oude recht had de zogenaamde fideï-commissaire making, alsmede de afgeleide fideicommis de residuo, nog zelfstandige betekenis. Het wigerende erfrecht beschouwt dexe making als een species van het genus voorwalrdelijke makingen. Dit werklatart tevens waaron de term fideicommisaire making in het huidige Boek 4 niet meer voorkomt. Zie voor een behandeling van de fidei-conmissaire making naar oud en nieuw recht Handboek Nieuw Erfrecht (2002) hoofdstuk IX 83.7, alsook BLOKLAND en STOLLENWERCK in WPNR 6574/6575 (2004). Voor de "verboedering van de fidei-commis de residuo en het wruchtgebruik met bevoegdheid to vervreenden en verteren verwijs ik naar Van Gaalen, diss., nr. 093 en verder

139 Teneinde deze voorwaarde niet tot in lengte van jaren als een zwalard wan Damodes boven het hoofd van zoon $\mathrm{A}$ te laten hangen, heeft de wetgewer een limiet wan 30 jaar opgenomen. Art. 4:140.

140 Ontbreekt een erfstelling in deze zin dan geldt volgens art. 4:138 lid 3 dat de erfgenaam onder ontbindende voorwalarde de bevoegcheid tot vervreending en vertering toekont "op dezelfide voet als de vruchtgebruiker'. Vergelijk de regeling van art. 4:136 lid 2 .

141 Aldus art. 4:138 lid 2. VERSTAPPEN geeft een overzicht van de bepalingen welke in $20^{\circ}$ ngeval van (overeenkomstige) toepassing zijn. Handboek Nieuw Erfrecht (2002), hoofdstuk IX \&3.\|l en 3.12 In $\$ 3.13$ behandelt hij de bepalingen die niêt van toepassing zilint. 


\subsection{Vererving van aandelen en de erfrechtelijke blokkade}

\subsubsection{Inleiding: de statutaire erfrechtelijke blokkade}

Uit de voorgaande paragrafen valt te concluderen dat er een aantal mogelijkheden bestat om het recht van vruchtgebruik op een aandeel in een kapitaalvennootschap in het leven te roepen. Alvorens het recht van vruchtgebruik gevestigd kan worden op een aandeel op de gronden zoals deze hierboven zijn omschreven, dient eerst de vererving van de aandelen te worden besproken. Deze vererving kan namelijk met regeis van vennootschapsreeht worden geconfronteerd waardoor de vestiging van geschetste vruchtgebruikvormen complexer wordt: Kapitaalvennootschappen kunnen vooreerst de overdracht van aandelen beperken. Voor de BV is een dergelijke blokkering verplicht en bij de NV optioneel. ${ }^{142}$ Zulks raakt echter niet aan de overgang krachtens erfrecht, omdat het evident geen overdracht betreft. Om de beslotenheid van de kring van aandeelhouders in deze gevallen te bewaken, kan de vennootschap ervoor kiezen een zogenaamde "erfrechtelijke blokkade" ${ }^{143}$ in de statuten op te nemen. ${ }^{144}$ Vooropgesteld dient te worden dat een dergelijke blokkade niét kan voorkomen dat de erfgenamen rechthebbenden worden van het aandeel; enkel de duur van het aandeelhouderschap kan worden beperkt. ${ }^{145}$ Wanneer de erfgenamen/aandeelhouders niét meewerken aan hun aanbiedingsverplichting kan de vennootschap, indien statutair bepaald, de aandeelhoudersrechten van deze aandeelhouders beknotten: ${ }^{146}$

De erfgenaam of erfgenamen die krachtens erfrecht en onder algemene titel rechthebbenden zijn geworden van aandelen uit de nalatenschap van de erflater kan of kunnen statutair worden verplicht deze aandelen over te dragen. Voor het geval een dergelijke blokkade door een BV is opgeworpen en aandelen van deze BV zich in de nalatenschap bevinden rijst de vraag wat voor effect dit heeft in de verschillende erfrechtelijke situaties en of, en zo ja hoe, dit de vestiging van een beperkt recht raakt.

142 Art. 2:195 respectievelijk art. 287. Asser/Maeijer 2-111 (2000), nr. 211.

143. C.A. Sehwatz, diss. RUL (1986), p. 122.

1.44 Betreft het zoals hier bedoeld een intern besloten $13 \mathrm{~V}$ zal men er in de regel tevens toe overgaan de vrije kring van att. 2:195 geheel uit te sluiten. Bovendien wordt in deze situatie gekozen voor een aanbiedingsblokkade. Schwart, diss., respectieveligk p. 79 en 142. In het vervolg van de bespreking wordt anngenomen dat wan deze twee modaliteiten gebruik wordt gemaakt.

145 Schwarz, diss, p. 124-125. Het feit dat het aandeelhouder worden niet kan worden voorkomen is tevens de reden dat van een blokkeringsregeling in eigenlijke zin niet kan worden gesproken. Sehwarz, diss., p. 121.

146 Art. 2:195a lid 1 alsmede Schwarz, diss, p. 122-123 dewelke destijds uitging van de voorganger van het betreffende artikel, te weten $\$ 25$ van de Departementale Richtlijnen (1986). Mocht medewerking nog immer achterwege blijven kan dit, mits wederom statutair bepaald; cullmineren in een onherroepelijke volmacht voor de vennootschap om de aandelen aan te bieden en over te dragen (lid 2). 


\subsubsection{Versterferfrecht: de wettelijke verdeling en her voorbehouden whuchtgebruik}

De mogelijkheid tot het vestigen van een recht van vruchtgebruik binnen het versterferfrecht, te weten het voorbehouden vruchtgebruik na uitoefening van wilsrech$\operatorname{ten}^{147}$, wordt voorafgegaan door de wettelijke verdeling. Wanneer aandelen tot de nalatenschap behoren worden deze krachtens erfrecht door de langstlevende verkregen. Zoals reeds besproken kan niet voorkomen worden dat de langstlevende rechthebbende van de aandelen wordt. Een aanwezige "erfrechtelijke biokkade' beperkt slechts de duur van het aandeelhouderschap. De langstlevende is gehouden de aandelen aan te bieden aan de (eventueel aanwezige) overige aancteelhouders alvorens de langstlevende onvoorwaardelijk tot de besloten kring van aandeelhouders wordt toegelaten. De conclusie voor wat betreft de wilsrechten en het voorbehouden vruchtgebruik kan de overige erfgenamen een wrange nasmaak bezorgen. De aandelen kunnen alvorens een wilsrecht kan worden uitgeoefend, uit het zicht van de kinderen verdwijnen als gevolg van reflectie door de aandeelhouders. Wat rest is hetgeen terugkomt voor de vervreemde aandelen. Er vindt immers substitutie plaats op grond van artikel 4:24 lid 2. Het feit dat de aandelen uit het zicht van de kinderen verdwijnen is echter niet onbillijk te achten nu dit een rechtstreeks gevolg is van het besloten karakter van de BV.

In het theoretische geval ${ }^{148}$ dat de erfgenamen wel het hun toebedeelde wilsrecht kunnen uitoefenen, kan men zich afvragen of de aandellen, waarop een verplichting tot aanbieding 'rust', op grond van het wilsrecht kunnen worden ovvergedragen. Naar mijn smaak zal moeten gelden dat een zodanige overdracht, op voet van het arrest "Schellens/Schellens" 149, enkel kan plaatsvinden op de voorwaarde dat de overige aandeelhouders zich onthouden van reflectie. Het in eerste instantie niet reflecteren heeft als consequentie dat de langstlevende onvoorwaardelijk wordt toegelaten tot de kring van aandeelhouders. Hiermee wordt slechts het eerste obstakel op weg naar het voorbehouden vruchtgebruik overwonnen. Wanneer het beroep op de wilsrechten wordt gehonoreerd wordt de daaruit volgende overdracht wederom met een blokkeringsregeling geconfronteerd. Ditmaal gaat het on de reguliere verplichte blokkeringsregeling uit artikel 2:195, aangezien het hier een overdrachr betreft. Afhankelijik van welk regime is gekozen heeft goedkeuring of niet aanvaarding van het aanbod een dubbele consequentie. Ten eerste wordt het aandeel overgedragen aan het kind en wordt deze opgenomen in de kring van aandeelhouders. Ten tweede behoudt de langstlevende/vervreemder, mits zij zich het recht van vruchtgebruik voorbehoudt, in

\section{Vergelijk $\$ 3.4$.}

148 Het geval is in zoverre theoretisch dat de statutaire verplichting tot aanbieding onistaat op het moment van werkrijging door de langstlevende. Uit \$3.4.1. van dit hoofdstuk is gebleken dat de wilsrechten pas na verloop wan tijd zullen ontstaan. Aangenomen moet worder dat tegen de tijd dat een wilsrecht ontstaat de aandelen reeds zijn overgedragen of gedeblokkeerd door uitblijven van reflectie.

$\rrbracket 49$ HR 11 april 1958, NJ 1958, 302 (Schellens/Schellens). PJ. Dortmond, diss. KUN (1989), p. 32. 
beginsel zijn stemrecht in de aandeelhoudersvergadering. ${ }^{150}$ Herhaald zij dat de kans dat het wilsrecht zo kort na overlijden van de erflater ontstaat te verwaarlozen is.

\subsubsection{Testamentaïr erfrecht}

\subsubsection{Inleiding}

In het geval een erflater een testament heeft opgesteld, kan het dwingendrechtelijke verzorgingsvruchtgebruik van artikel 4:30 van invloed zijn op de wijze waarop het testament wordt uitgevoerd. ${ }^{15}$ De vraag of het verzorgingsvruchtgebruik van invloed is, is afhankelijk van een aantal voorwaarden. Een impliciete voorwaarde is dat anderen dan de langstlevende als gevolg van de uiterste wil van de erflater gerechtigd zijn tot goederen uit de nalatenschap. Wanneer de langstlevende weinig tot niets ${ }^{152}$ heeft ontvangen kan hij op grond van zijn verzorgingsbehoefte een beroep doen op zijn mede-erfgenamen en hen verplichten tot het vestigen van een recht van vruchtgebruik op andere goederen uit de nalatenschap. De langstlevende kan in dit kader zo nodig overgaan tot het inkorten van giften. ${ }^{153}$ In de volgende paragrafen zal worden besproken hoe andere personen dan de langstlevende bij de afwikkeling van de nalatenschap betrokken kunnen zijn. Bij de bespreking zal wederom aandacht geschonken worden aan de blokkeringsregelingen. In de slotparagraaf wordt het effect van deze regelingen op het (verzorgings-) vruchtgebruik op aandelen behandeld.

\subsubsection{Erfgenaam en erfstelling}

De positie van de erfgenamen bij versterf is reeds aan bod gekomen. ${ }^{154}$ De erflater kan de groep erfgenamen in zijn uiterste wil uitbreiden door een erfstelling. Een dergelijke beschikking houdt in dat de begunstigde (rechts)persoon, evenals een (eventuele) versterferfgenaam, als erfgenaam onder algemene titel verkrijgt. ${ }^{155}$ De situatie die zich voordoet wanneer de nalatenschap aandelen omvat is vergelijkbaar met de situatie zoals deze is beschreven in \$4.2. De betreffende persoon verkrijgt weliswaar de aandelen, maar deze vallen onder een erfrechtelijke blokkade op grond waarvan de gezamenlijke erfgenamen gehouden zijn de aandelen aan te bieden aan de medeaandeelhouder(s) of aan de wennnootschap. Slechts na uitblijven van reflectie wordt de betreffende erfgenaam onvoorwaardelijk opge-nomen in de kring van aandeelhouders.

150 Art. 2:197 lid 3. Zulks geldt indien niet anders door partijen of de kantonrechter op woet van art. $4: 23$ lid 4 is bepaald.

151 Vergelijk $\$ 3.5$.

$152 \mathrm{In}$ het geval de langstlevende onterfd is.

153 Zie art. 4:34 lid 1 jo art. 4:89 en 4:90.

154 Vergelijk \$3.3.1.1.

155 Art. 4:115 jo 4:182. Handboek Nieuw Erfrecht (2002), p. 127 


\subsubsection{Legaat}

Betreft de testamentaire beschikking een legaat van aandelen dan wordt de witvoening van het legaat reeds tegengehouden door de 'gewone' blokkerings-regeling uit artikel 2:195. De erfgenamen zijn gehouden het vorderingsrecht, welke door het legaat wordt gevormd, te voldoen. Het legaat geldt als titel van overdrachi. ${ }^{156}$ Uit de regeling van het verzorgingsvruchtgebruik valt op te maken dat ook gelegateerde goederen voor vestiging van het bedoelde vruchtgebruik in aammerking komen, voor zover de overige goederen niet in de verzorgingsbehoefte van de langstlevende kunnen voorzien. ${ }^{157}$ Het Hof Den Bosch oordeelde in "Schellens/Schellens" "158 dat een voorgenomen overdracht voorwaardelijk moet worden geacht, indien de blokkeringsregeling waaraan zij moet worden onderworpen nog niet is geëerbiedigd. VAN MouRK concludeert in dit kader dat wanneer aandelen worden gelegateerd en "een legataris niet meedanst in de vrije kring' het legaat slechts als woorwaardelijke making gekarakteriseerd kan worden. ${ }^{159}$ Het voert echter te ver de erfrechtelijke regels inzake de voorwaardelijke making ${ }^{160}$ op deze conclusie van toepassing te verklaren. De voorwaardelijkheid is immers alan een korte termijn verbonden. Zodra de vennootschapsrechtelijke horde van de blokkeringsregeling is genomen is er van een voorwaarde geen sprake meer.

\subsubsection{Verzorgingsvruchtgebruik}

Een buitengewoon probleem rijst ten aanzien van het vruchtgebruik op geblokkeerde aandelen. Aangenomen dat de langstlevende een verzorgings-behoefte heef, kan zij goederen aanwijzen op welke zij een recht van vruchtgebruik te harer behoeve gevestigd wil zien. Dit recht komt haar toe direct na het overlijden van de erflater tot maximaal een jaar daarna: ${ }^{16}$ Nu geconcludeerd is dat aandelen onder algemene titel weliswaar overgaan, maar dat bij het bereiken van de bestemming deze aandelen erfrechtelijk geblokkeerd kunnen zijn, ontstatat een erfrechtelijk dillemma: kan het verzorgingsvruchtgebruik worden gevestigd op de (erfrechtelijk) geblokkeerde aandelen? ${ }^{162}$

156 Reeds in $\$ 3.3 .1 .2$ werd erop gewezen dat het legat en verknjging onder bjzondere titel betreft. Vergelijk in dit kader art 2.195 hi 3 hetwelk bepall dat de owerdracht vain erfgemamen an de reflecterende sandeelhouder geldt als overdracht door de erflater. Wainneer de statuten cen vije kring kemen wordt op deze manier bewerkstelligd dat een prelegat awn iomand binnen dere kring niét onder de wettelike blokkeringsregeling valt. Zie de MvT bij de inwoening van dexe bepaling Kamersitwken If 1998-1999, 26277, ni: 3, p. 12.

157 Aldus ant $4: 30$ lid 5.

158 Hof "s-Hertogenbosch 28 mei $1957, N J \llbracket 1958,129$.

159 M.A. van Mourik, "De Eewnoms-BV (1980), p. 4ll alsook Schwarz, diss, p. 163. De voorwarde is dat niew wordt gereflecteerd op de aangeboden aandelen.

160 Vergelijk $\$ 3,6.3$

161 Art, $4: 31$ lid 2.

162 Dit dilemma betreft zowel erfrechtelijk als tegulier geblokkeetde andelen. In het eerste geval zijn, bij uitshiting van de wettelijke verdeling, neerdene ërfgenamen samen onder algemene titel recht hebbende geworden. De reguliere blokkeringsregeling dawrentegen bilokkeart de overdracht van wandelen door middel wan een legat. 
Naar mijn mening zal in beginsel niets aan de vestiging in de weg te staan. De erfgenaam die op grond van de uiterste wil de aandelen verkrijgt, moet, ondanks de (erfrechtelijke) blokkade, woorwaardelijk beschikkingsbevoegd geacht worden de betreffende aandelen te bezwaren. De wruchtgebruiker kan zich daarbij gesterkt voelen door het feit dat de wetgever heeft bepaald dat de vestiging van het vruchtgebruik niet kan worden beperkt of uitgesloten. ${ }^{163}$ Sterker nog, precies deze bepaling is opgenomen on vruchtgebruik op aandelen als verzorging van de langstlevende blijvend mogelijk te maken..$^{164}$ Weliswaar heeft de wetgever het verzorgingswruchtgebruik uit het nieuwe erfrecht claarbij destijds niet voor ogen kúmnen hebben, maar de strekking van zowel deze regeling als die van de onbeperkte bezwaring is eenduidig. Reeds hieruit kan de conclusie worden getrokken dat het de vruchtgebruiker vrijstaat de aandelen te kiezen voor zijn verzorgingsvruchtgebruik. Ten slotte kan à contrario een argument gevonden worden in de ratio van de beidle blokkeringsregelingen. Zowel de wettelijk verplicht gestelde blokkeringsregeling als de erfrechtelijke blokkade dienen als waarborg voor de beslotenheid van de betrokken kring van aandeelhouders in de BV. De beslotenheid richt zich op de lidmaatschapsver-houding en dan met name op het aspect van zeggensmacht. ${ }^{165}$ Het verzorgingsvruchtgebruik nu raakt niet aan dit doel van de blokkeringsregelingen. De bezwaarde aandeelhouder blijft in beginsel bevoegd zijn stemrecht in de vennootschap uit te oefenen. ${ }^{166}$ Vestiging van het verzorgingsvruchtgebruik raakt dientengevolge niet aan de beslotenheid van de vennootschap. ${ }^{167}$ Een eventueel toekomende vervreemdingsbevoegdheid van de vruchtgebruiker doet hier niets aan af aangezien een daaruit volgende overdracht geacht mag worden onder de reguliere blokkeringsregeling te vallen.

De rechthebbenden dienen mijns inziens blijkens het voorgaande mee te werken aan de vestiging van het verzorgingsvruchtgebruik en zij zijn slechts in dit geval - de langstlevende doet een beroep op het verzorgingsvruchtgebruik - én op die voorwaarde --vestiging van het vruchtgebruik - beschikkingsbevoegd. De beschikkingsonbevoegdheid die voortvloeit uit het blokkeren van aandelen ${ }^{168}$ is naar mijn overtuiging derhalve niet absoluut. Mocht het zover komen dat de bezwaarde geblok-

\section{Art. 2:197 lid 1 .}

164 Kamerstukken II 1973-1974, 12897 , ar. 3. p. 4. Zie tevens \$4.2.1.

165 M.J.A. van Mourik, 'De Eenmans-BV' (1980), p. 37; Schwarz, diss, p. 122

166 De regel dat de aandeethouder stengerechtigd blijft, lijdt slechnts uitzondering indien er sprake is van cen voorbehouden vruchtgebruik in het kader van uitoefening wan een willsrecht. De slotzin wan art. 2: 197 lid 3 kent in dat geval de vruchtgebruiker het stemrecht toe. Volgens de MvJ lag deze uitzondering in het kader van het verzorgingsvruchtgebruik "minder woor de hand". De vraag wăaron dat minder voor de hand lag, wordt niet gesteld, laat staan beantwoord. Kamerstukken II $1999-2000$. 27245 , nr. 3, p. 4. Zie voor verdere bespreking van het vruchtgebruik op aandelen en het stemrecht $\$ 2.1$ wan hoofdstuk $\mathrm{V}$.

167 Als ik het goed lees, hebben zowel VAN MonRIK als SCHWaRz dit reeds cerder verdedigd Vergelijk respectievelijk M.J.A. van Mourik, NV 61 (1983), p. 127 en C.A. Schwarz, NV 61 (1983), p. 223, later herhaald in zijn dissertatie (Schwarz, diss., p. 77).

168 Aldus Asser/Maeijer 2-III (2000), nr. 216. 
keerde aandelen worden overgedragen in het kader van een van beide blokkeringsregelingen, dan volgt uit de regel van het 'droit de suite' dat het vruchtgebruik ten behoeve van de langstlevende in stand blijft. Gezien de bevoegdheden die de langstlevende heeft ${ }^{169}$ vormt zij een geducht blok aan het been van de nieuwe aandeelhouder. Als gevolg van deze uitgebreide bevoegdheden verschilt de positie van de langstlevende als vruchtgebruiker goederenrechtelijk gezien niet veel van die van de rechthebbende van het aandeel. De medeaandeelhouder zou kunnen overwegen de erfgenaam als aandeelhouder in de besloten kring op te nemen door niet te reflecteren op diens verplichte aanbod. Daarmee vergooit hij echter de mogelijkheid, wanneer het vruchtgebruik niet reeds gevestigd is, de langstlevende vruchtgebruiker met diens bevoegdheden en mogelijke lidmaatschapsrechten buiten de deur te houden. Reflectie door de medeaandeelhouder voór het uitoefenen van het verzorgingsvruchtgebruik leidt er immers toe dat het vruchtgebruik niet (meer) op de aandelen kan worden gevestigd. Artikel 4:30 lid 2 stelt dat het vruchtgebraik dan gevestigd moet worden op hetgeen voor de - krachtens de blokkeringsregeling - overgedragen aandelen in de plaats treedt. ${ }^{170}$

Bij dit alles dient evenwel aangetekend te worden dat de vorenstaande complicaties mee kumnen wegen indien de keuze van de langstlevende tot onderwerp van geschil wordt. Adiëren partijen de rechter op grond van artikel 4:30 lid 6 dan zal deze de vennootschapsrechtelijke implicaties mee laten wegen in zijn oordeel. Aangenomen moet worden dat slechts in het geval de litigieuze aandelen in de BV een substantieel deel van de nalatenschap vormen - men denke hierbij aan de familie-BV - de vordering van de langstlevende zal worden toegewezen. Immers, in dat geval is het vruchtgebruik op de aandelen te verkiezen boven het vruchtgebruik op de vordering die daarvoor in de plaats treedt.

\subsubsection{Aandeelhoudende erfgenamen}

\subsubsection{Inleiding}

Naast de erfgenamen die worden gedwongen om de aandelen uit de nalatenschap over te dragen hoort een bijzondere categorie erfgenamen in deze bespreking thuis: aandeelhoudende erfgenamen. Niet zelden is een van de erfgenamen reeds aandeelhouder in de betrokken vennootschap. In dit kader moet met name gedacht worden aan de familie-BV. Het overdragen van aandelen die deel uitmaken van een nalatenschap aan de zittende aandeelhouders/erfgenamen is op zichzelf (een) doel van de erfrechtelijke blokkade. Toch resteert de vraag of het vennootschaps-recht hier niet moet wijken voor het erfrecht. Daarbij speelt met name de 'saisine' een rol van betekenis. De 'saisine'-regeling houdt kort gezegd in dat de erfgenamen'17 de vermo-

169 Zie 83.3 .4

170 Vergelijk $\$ 3.5$.

171 Ten overvloede zij hier wermeld dat degene die deelgenoot in de nalatenschap is krachtens erfistelling in deze zin eveneens als erfgenaam dient te gellden. Vergelijk \$3.3.1.2. 
gensrechtelijke positie van de erflater voortzetten. ${ }^{172}$ Specifiek dient de vraag zich aan hoe de rechten van de aandeelhouders op grond wan het vennootschapsrecht zich verhouden tot hun positie als voortzetter van de vermogensrechtelijke positie van de erflater.

\subsubsection{Blokkering van aandelen en de saisine}

In de hierboven gestelde vraag echoot wederom de casus van 'Schellens/ Schellens'. In "Schellens/Schellens" bewonden zich in de nalatenschap van erflaatster X 104 aandelen in Schellens en Co. NV: De NV kende een statutaire aanbiedingsverplichting. Voor haar overlijden verleende de erflaatster een koopoptie aan de NV voor 71 van haar aandelen, uit te oefenen na haar overlijden. Bovendien legateerde ze tegen inbreng van de waarde de overige 33 aandelen aan haar dochter $\mathrm{A}$, warmee ze beoogde deze de meerheid in de aandeelhouders-vergadering te geven. Zowel dochter $\mathrm{A}$ als kinderen $\mathrm{B}$ en $\mathrm{C}$ waren reeds aandeelhouder in de betrokken NV. Als erfgenamen van de erflaatster verkregen de drie kinderen de 71 aandelen waarop de zoëven genoemde koopoptie rustte. De Hoge Raad oordeelde dat woor zowel de uitoefening van de koopoptie als de uitlevering van het legaat de statutaire blokkeringsregeling in acht diende te worden genomen.

De in dit kader bijkomende relevante vraag die zich aandiende was of de kinderen gezien de voor overlijden aangegane obligatoire verbintenis alsmede gezien de uiterste wil van de erflaatster gehouden zijn niét op het statutair verplichte aanbod aan henzelf in te gaan. Daar de erfgenamen op grond van de saisine de positie van de erflater voortzetten is de vraag gelegitimeerd of zij op deze manier de door de erllater aangegane verbintenissen en testamentaire makingen kunnen frustreren. De beantwoording van deze vragen komt neer op een interpretatie van de saisine: In hoeverre drukken de verplichtingen die de erflater voor zijn dood is aangegaan of in het leven heeft geroepen op de erfgenamen? DoRTMOND oordeelt in zijn dissertatie dat de rechten uit de blokkerings-regeling(en) die erfgenamen toekomen op grond van hun eigen aandelenbezit ertoe leiden dat de erfgenamen gerechtigd zijn te reflecteren op de aandelen uit de nalatenschap. ${ }^{173}$ In zoverre wordt de saisine hiermee opzij gezet.

SCHWARZ kemt in zijn dissertatie tot de conclusie dat strikte interpretatie van de saisine er wél toe leidt dat de erfgenamen, als opvolgers in het vermogen van de erflater, gehouden zijn precies te doen wat de erflater zou hebben moeten doen; niet reflecteren. ${ }^{174}$ Dit omdat de erflater zelf ook niet had kunnen reflecteren. Bij een

172 De "saisine"-negeling is afkomstig van het adagum "le mort saisit le vif" hetgen enigszins morbide wordt vertaald als "de dode neemt bezit van de levende'. De saisine-regel vindt in het nieuwe erf* recht zijn weerslag in onder andere art. 4:182. Zie voor deze erfrechtelijke regeling in het algemeen Handboek Nieuw Erfreeht (2002), p. 53 en verder. Voor een meer rechtshistorische beschouwing verwijs ik naar Asser/Van der Ploeg.Perrick (1996), nr. 310.

173 P.J. Dortmond, diss. KUN (1989), p. 52.

174 Schwarz, diss, p. 146m 147. Aarvankelijk week het standpunt van VaN Mounik af van deze gedachte van ScHWarz (M.J.A. wan Mourik, "De Eenmans-BV" (1980), p. 40). Later herzag hij zijn mening en bepleitte eveneens een strikte toepassing van de saisine. M.J.A. van Mourik, "Erfrecht' (1997), p. 40. 
belangenafweging tussen het erfrecht en het vennootschapsrecht met bijzondere aandacht voor de blokkeringsregeling als waarborg van de beslotenheid van de vennootschap staat hij een uitzondering op de saisine woor: 175

DORTMOND's oordeel en zijn daarmee gepaard gaande dogmatische onderbouwing vinden brede steun in de literatutur. ${ }^{776}$ Voor wat betreft de uitkomst behoeft hier geen keuze voor SCHWARZ' uitzonderingen op dan wel DORTMOND"s beperking van de saisine gemaakt te worden. Beide zijn van mening dat aandeelhoudende erfgenamen in dit geval gerechtigd zijn te reflecteren, zulks om de vennootschapsrechtelijk besloten kring te waarborgen.

\subsubsection{Verzorgingsvruchtgebruik}

De conclusie van DORTMOND uit de vorige paragraaf wordt zoals gezegd breed gedragen. Het verzorgingsvruchtgebruik wordt echter wel met het spreekwoordelijke badwater weggespoeld. Immers, het reflecteren door aandeel-houdende erfgenamen ontneemt aan de langstlevende de mogelijkheid tot het doen vestigen van een recht van wruchtgebruik. Het is gerechtvaardigd de vraag te stellen of zulks geen andere uitkomst kan hebben. Doordat de aandeelhoudende erfgenamen reflecteren op de aandelen wordt door de daaropvolgende overdracht de vestiging van het recht van vruchtgebruik bemoeilijkt. De aandelen verdwijnen uit de nalatenschap en de langstlevende moet genoegen nemen met een vruchtgebruik op hetgeen daarvoor in de plaats treedt. ${ }^{177}$ Let wel, de aandejen zijn overgedragen door de erfgenamen uit de nalatenschap aan de aandeelhoudende erfgenamen. Een dergelijke 'cosmetische' vermogensverschuiving maakt het vruchtgebruik op aandelen vool de langstlevende illusoir. Een vergelijkbaar probleem manifesteert zich bij legatering van aandelen. Wanneer aandeelhoudende erfgenamen reflecteren op het ex artikel 2:195 verplichte aanbod, verdwijnen ook deze aandelen uit het zicht wan de langstlevende voor wat. betreft het vestigen van het verzorgingsvruchtgebruik. Het effect van een erfrechtelijke blokkade voor het geval dat erfgenamen reeds aandeelhouder zijn, is dat door

175 Deze uitzondering ziet wat SCHwaz betreft op zowel obligatoir handelen (koopolste/verkoop met nirgestelde levering) van de erflater voor overlighen, als legatering wan andelen door deze. $5 \mathrm{cljwatz}$ diss. respectievalijk p. 157 en 168

176 Handboek NV/BW (1992), nr. 181.3 in fine; Asser/Maejer 2 IIl (2000), n*. 213; W. Westbrok, RM Thents 1989-9, p 465-466. De conclusie werd overigens in de zank "Schellens/Sehellens" ook door het Hof s-Hertogenbosch getrokken (Hof "s-Hertogenboseh 28 mei 1957, NJ 1958, 129 (Schellens/Schellens), de Hoge Razd deed evenwel niets met deze ingenomen stellng. Opwallend is overigens wel dat opponenten wan deze leer veelal te winden zijn in de sfeer van de erfrechtelijke literaturi: P.W. van der Plogg, WPNR 5290 (1975), p. 21; A. G. van Solinge, in: "Wan der Ploeg-bundel" (1976), p. 163; Asser Van de Ploeg-Perrick (1996), nr. 524, alsmede Assemiperrick 6A (2002), nt: 365 en de reeds eerder genoemde VAN MOUkIK (vergelijk noot 174 supra)

177 Art 4:30 hd 2. Wooropgesteld dat hij niet onmiddellik en aldus vón reflectie gebruik gemaalk heoft wan het techt, zoals besproken in $\$ 3.5 .4$ 
reflectie het vruchtgebruik op aandelen kan worden uitgesloten. De vraag rijst of potentiêle verzorgingswruchtgebruiker dit dient te accepteren. ${ }^{178}$

Vooropgesteld moet worden dat het geschetste probleem vermeden kan worden. Wanneer de langstlevende tijdig, dat wil zeggen voordat het verplichte aanbod wordt gedlaan, gebruik maakt wan het recht uit artikel 4:30 staat niets aan de vestiging wan het recht van vruchtgebruilk ten behoeve van de langstlevende in de weg. De gezamenlijke erfgenamen moeten voorwaardelijk beschikkingsbevoegd geacht worden dit recht van wruchtgebruik in het leven te roepen. ${ }^{179}$ Hebben de aandeelhoudende erfgenamen echter reeds gebruik gemaakt van hun recht de aangeboden aandelen over te nemen, ontstaat naar mijn smaak een situatie die vermeden had mogen worden.

Twee routes zijn in dit geval denkbaar. Ten eerste kunnen de erfgenamen besluiten niêt te reflecteren. De aandelen worden niet gesubstitueerd door de vorderingen op de reflecterende erfgenamen ${ }^{180}$ en blijven vatbaar voor vestiging van het vruchtgebruik. Ten tweede kan worden gesteld dat de aandeelhoudende erfgenamen, ondanks het feit dat overgedragen aandelen niet onder het bereik van artikel 4:30 vallen, gehouden zijn mee te werken aan de vestiging van een recht van vruclutgebruik ten behoeve en ter verzorging van de langstlevende. In de eerste oplossing wordt een regel van vennootschapsrecht doorkruist door een regel van erfrecht, in het tweede geval gebeurt het omgekeerde. De eerste oplossing stuit op het probleem dat een dergelijk besluit niet afdwingbaar is. ${ }^{181}$ Mijn voorkeur gaat derhalve uit naar de tweede situatie waarin de langstlevende dle mogelijkheid wordt geboden ná reflectie het vruchtgebruik op de aandelen alsnog te doen vestigen. Reden hiervoor is de instandhouding van bescherming van de besloten kring. ${ }^{182}$ Om dit mogelijke te maken dient de wetgever echter een uitzondering opnemen op grond waarvan de goederenrechtelijke regel van substitutie van artikel 4:30 lid 2 voor wat betreft aandelen verkregen op grond van rechten uit de blokkerings-regeling(en) door reeds aandeelhoudende erfgenamen buiten werking wordt gesteld. Uit hoofd van hun kwaliteit als erfgenamen dienen zij naar mijn smaak gehouden te zijn het verzorgingsvruchtgebruik op de aandelen te accepteren, mocht het vruchtgebruik op de aandelen de voorkeur genieten van de langstlevende.

178 Saillant detall is dat deze situatie in het teven wordt geroepen door het opzijzetten van de in het erfrecht zo belangrijke regel van de saisine die volgens VAN DefR PLogG uitdrukking geeft aain de morele kant van het erfreclit. P.W. van der Ploeg, WPNR 5290 (1975), p. 22.

170 Vergelijk 83.7 .3 .4 .

180 Op grond varn art: $4: 30$ lid 2 openingszir.

181 Helas zal artikel $2: 15$ de potentiele verzorgingsvouchtgebruiker, mocht hij al tot de betreffende redelijkheids- en billijkheidskring van artikel $2: 8$ behoren, geen soelaas bieden nu hij juist nog geen vnchtgebruiker op de aandelen is. Bespreking van de vruchtgebruiker en de kring van att. $2: 8$ vindt plats in $\$ 6.3$

182 In $\$ 3.7 .3 .4$ had ik reeds geconchuderd dat de vestiging van een recht van vruchtgebruik deze besloienheid niet raakt. 


\subsection{Conclusie}

De rol van het recht van vruchtgebruik in het erfecht is prominent te noemen. Zowel onder het oude als onder het nieuwe erfrecht kont het vruchtgebruiksysteem een belangrigke plek toe bij het afwikkelen van nalaten-schappen. Onder het oude recht vervulde het vruchtgebruik voornamelijk een rol wanneer de erflater daarvoor had gekozen en derhalve op testamentaire gronden werd gevestigd. Een keuze die, mede ingegeven door het verouderde ab intestaat erfrecht, zeer getegeld werd gemaakt: De ontwikkeling van het recht van vruchtgebruik als instrument van erfrecht heeft alles te maken met het karakter en de mogelikheden van vruchtgebruik. De erflater kan met behulp van het wruchtgebruiksysteem er niet alleen yoor zorgen dat de langstlevende na het overlijden "in de spullen" kan blijven, maar hij kan de langstlevende tevens van een inkomen voorzien. Daarenboven voorkomt de erflater dat - bestanddelen van - zijn vermogen na overlijden van de langstlevende de familie verlaat. De civiel-rechtelijke modaliteiten worden bovendien ondersteund door de fiscale aanrekkelijkheid van het vruchtgebruik. Het is daarom niet verwonderlijk dat het vruchtgebruik een instrument van betekenis is voor de praktijk van de 'estate planning'. De bijzondere eigenschappen van het muchtgebruik zijn de wetgever bij de ontwikkeling van het nieuwe erfirecht niet ontgaan. Hoewel het vruchtgebruik-systeem als uitgangspunt woor het nieuwe ab intestaat erfrecht - als gevolg van zijn complexiteit - de eindstreep niet haalde, viel men er wel op terug om enkele oneffenheden in het "langstlevende al'-systeem glad te strijken. Ook hier wordt handig gebruik gemaakt wan de scheiding van belangen die het vruchtgebruik mogelijk maakt. In het bijzonder geeft het verzorgingsvruchtgebruik de bruikbaarheid en flexibiliteit van het vruchtgebruikinstrument weer. Deze vorm van vruchtgebruik zet krachtig in op met name het uitbreiden van de bevoegdheden van de wruchtgebruiker. De langstllevende krijgt op deze wijze een verregaande autonomie ten aanzien van het bezwaarde goed. Hoewel de hoofdgerechtigde op grond van regels van goederenrecht een juridisch sterke positie lijk:t toe te komen moet zulks in het kader van het nieuwe erfreclit enigszins worden gerelativeerd. Zo wordt de goederenrechtelijke substitutieregel vervangen door een werbintenis-rechtelijke vergoedingsregeling. Daarenboven kan de hoofagerechtigde geconfronteerd worden met een - bij de kantonrechter afgedwongen - recht tot vertering van de vruchtgebruiker. Naast het verzorgingswruchtgebruik speelt het voorbehouden vruchtgebruik bij wilsrechten een centrale rol het in nieuwe erfrecht. Deze vorm van vruchtgebruik legt de nadruk in eerste instantie op de hoofdgerechtigde daar zij bedoeld is om het stieffamilie-gevaar te ondervangen. De belangen moeten in dit kader echter wel in balans gebracht worden en ook hier geniet de vruchtgebruiker een sterkere positie dan in het goederenrecht.

De versterkte positie van de vruchtgebruiker is te verklaren aan de hand van de verzorgingsgedachte die in het nieuwe versterferfrecht een prominente rol speelt. De langstlevende moet, binnen de grenzen van het redelijke, zoveel mogelijk vrijheid worden gegeven om haar leven na het wooroverlijden van harar echtgenoot op dezelfde voet voort te zetten. Deze gedachte blijft overeind indien aandelen in een kapi- 
taalvennootschap tot de nalatenschap behoren. Betreft het aandelen in een BV dan komt een beroep door de langstllevende op een verzorgingsvruchtgebruik door de (erfrechtelijke) blokkeringsregeling in het gedrang. Mede-erfgenamen die reeds aandelen in de BV houden, kunnen met gebruik van de blokkeringsregeling, de vestiging van het verzorgingswruchtgebruik op de aandelen frustreren. Wanneer deze erfgenamen de bedoelde mogelijkheid te baat nemen, moet de langstlevende genoegen nemen met een verzorgingsvruchtgebruik dat wordt gevestigd op hetgeen voor de overgedragen aandelen in de plaats treedt. 


\section{Hoofdstuk 4}

\section{VRUCHTGEBRUIK OP EEN AANDEEL}

\subsection{Inleiding}

In het worige hoofdstuk is besproken in welke situaties het erfrecht mogelijkheden biedt tot het vestigen van een recht van vruchtgebruik op een aandeel. In dit hoofdstuk wordt onderzocht hoe de vestiging van een recht van vruchtgebruik op een aandeel in juridische zin gestalte krijgt. Daarbij wordt niet alleen aandacht geschonken aan de goederenrechtelijke vereisten van vestiging, maar zal met name worden bezien welke additionele vennootschapsrechtelijke hordes moeten worden genomen, alvorens de vruchtgebruiker zijn rechtspositie binnen de kapitaal-vennootschap ten volle kan benutten. Bij dit laatste moet gedacht worden aan de voor de BV dwingend voorgeschreven blokkeringsregeling en de erkenning van de overdracht casu quo vestiging door zowel de BV als de NV in het kader van het uitoefenen van de lidmaatschapsrechten. Daarnaast zal de bijzondere regeling voor de vestiging van een recht van vruchtgebruik op een aandeel dat is opgenomen in het systeem van de Wet giraal effectenverkeer' in dit hoofdstuk aan bod komen.

\subsection{Vestiging}

\subsubsection{Inleiding}

De bevoegdheid tot het vestigen van een recht van vruchtgebruik op een aandeel in een kapitaalwennootschap kan niet statutair worden uitgesloten. ${ }^{2}$ Deze zinsnede werd bij de invoering van de wetswijzigingen rond de rechten van pand en wrichtgebruik op aandelen opgenomen in het BW. ${ }^{3}$ De belangrijkste reden was, ook toen al, de bruikbaarheid van het recht van vruchtgebruik in thet kader van de erfrechtelijke verzorging. Dit gebruik woog volgens de toenmalige Minister wan Justitie, zwaarder dan de vernootschapsrechtelijke bezwaren. ${ }^{4}$

1 Hiena: WoE. Overigens verdient hier opmerking dat de Woy, zoals de naam angeft, een doel van het Nederlandse "effectenrecht' regulect, hefgeen evident op meer ziet dan enkel asndelen in kapital vemootschappen. In het vervolg zal telkens worden gesproken over andelen.

2 Art $2: 88$ en 197 lid 1.

3 Wel van 17 mei $1976,5 i b .287$.

4 Kamerstukken $111973-1974,12897$, nr. 3, p. 4. 
Het startpunt voor de vestiging van elk beperkt recht vindt men in artikel $3: 98.5$ Vestiging van cen recht van wruchtgebruik op een goed geschiedt op dezelfde wijze als de overdracht wan dat goed. Voor vestiging van een recht van vruchtgebruik op een aandeel gelden aldus de vereisten woor overdracht van dat aandeel, te weten: een geldige titel, beschikkingsbevoegdheid van de vervreemder en een vestigingshandeling. ${ }^{6}$ Bespreking van de westiging van vruchtgebruik op aandelen zal in dit verband dientengevolge nauw samenhangen met de overdracht van aandelen. De voor vestiging vereiste titel is in wezen reeds grotendeels aan bod geweest. Immers, zoals geschetst in hoofdstuk 3 , is de titel veelal van erfrechtelijke oorsprong. De beschikkingsbevoegdheid, in het bijzonder bij vererving van aandelen, is in de slotparagrafen van het vorige hoofdstuk besproken. Dit hoofdstuk zal zich binnen de eisen voor vestiging met name richten op het vereiste van de levering. De wijze van levering wan een aandeel hangt af wan het soort aandeel en van de onderliggende kapitaalvennootschap. Om een helder beeld te krifigen van de vestiging van vruchtgebruik op aandelen, zullen de navolgende combinaties de revue passeren.

\section{Vestiging van een recht van vruchtgebruik op:}

- een aandeel op naam in een BV (\$4.3)

- een aandeel op naam in een beursgenoteerde NV (\$4:4)

- een aandeel aan toonder; onmiddellijk gehouden door de aandeelhouder ( $\$ 4.5 .3)$

- een aandeel aan toonder; in bewaring is gegeven door de aandeelhouder $(\$ 4.5 .4)$

- een aandeel aan toonder; verhandeld binnen het systeem van de $W_{\mathrm{GE}}(\$ 4.5 .5)$

\subsubsection{Overdracht, levering en vestiging: terminologie}

Alvorens de verschillende aspecten van de vestiging van een recht van vruchtgebruik te bespreken is het noodzakelijk aandacht te besteden aan de terminologie. De termen vestiging, overdracht en levering zijn nauw verwant. Vestiging van een beperkt recht op een goed geschiedt overeenkomstig de regels van overdracht voor dat goed, dus wanneer gesproken wordt van overdracht geldt dit ook voor vestiging, tenzij anders vermeld. Levering is, naast een geldige titel en beschikkingsbevoegdheid van de vervreemder; een constitutief onderdeel van de overdracht. Het gebruik van de term levering kan in dit kader bij de jurist voor verwarring zorgen. Dit is te wijten aan het feit dat twee verschillende elementen van de overdracht beide als levering kunnen

5 Overigens geld deze schakelbepaling tevens ingeval wan afstand van het beperkte recht. Daar war de witgebreide vereisten voor het in het leven roepen van een recht van vruchtgebruik op een aan deel nog te rechtvaardigen vallen, is het maa de vrag of deze vereisten op dezelfde rechtvaardiging

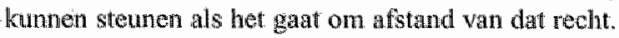

6 Vreemde cend in deze bijt is de regeling inzake de vestiging van een recht van vruchtgebruik op een aandeel dat valt onder de regeling van de Wot. Strikt genomen is het onzuver te spreken van overdrach in het kader wan de WGE. Uitgebrelde bespreking varn deze bijzondere regeling vindt plats in 5.5 .5 
worden aangeduid. Ten eerste de levering als naam voor do samengestelde rechtshandeling met als rechtsgevolg de overdracht. Ten tweede de levering als leveringsformaliteit die, naast de goederen-rechtelijke overeenkomst, onderdeel uitmakkt van de eerstgenoemde levering. ". Daar waar de levering als leveringsformaliteit bedoeld wordt, zal ik in het vervolg spreken van de leveringshandeling. De levering als vereiste voor een geldige overdracht blijf ik als levering betitelen.

Een vergelijkbare problematiek inzake de terminologie manifesteert zich bij de vestiging van een beperkt recht. ${ }^{8}$ De term vestiging wordt gebruikt voor zowel het beoogde rechtsgevolg $\mathrm{g}^{9}$, te weten het ontstaan van het beperkte recht, als voor hetgeen in dit geval als vestigingsformaliteit kan worden betiteld. ${ }^{10}$ Voor wat betreft dit onderscheid zal ik achtereenvolgens spreken van vestiging en vestigingshandeling. Dit hoofdstuk zal zich ingevolge de regeling van artikel 3:98 toespitsen op de te verrichten vestigingshandeling(en).

\subsection{Aandeel op naam in een $B V^{11}$}

\subsubsection{Inleiding}

De voltooiing van de volwaardige rechtspositie van een recht van vruchtgebruik op een aandeel op naam kent drie categorieën van voorwaarden. Ten eerste het goederenrechtelijke deel hetwelk gevormd wordt door de voltooiing van de vestiging overeenkomstig de regels van de overdracht. Ten tweede de erkenning van de vestiging door de BV die vereist is voor het toelaten van de vruchtgebruiker tot zijn lidmaatschapsrechten. ${ }^{12}$ Ten slotte dient te worden besproken of en in hoeverre de dwingendrechtelijke blokkeringsregeling van artikel 2:195 op de vestiging van een recht van vruchtgebruik van toepassing is.

7 Vergelijk Snijders-Rank-Berenschot (2001), ni. 325.

8 De verwarring wordt zelfs vergroot toor de redactie van de artiketen $2: 86$ en $2: 86 \mathrm{a}$, die telkens spreken van "levering van een beperkt recht". Kennelijk verstaat de wetgever data wel degelijk "vestiging van een beperkt recht' onder. Vergelijk Kamerstakken If 1988 - 1989, 21 155, an. 3, p. 3 allsmede Kamershokken II 1990 - 1991, 21 155, nr. 77, p. 4. In gelijke zin K. I.I. Visser, diss, RUL (2004, \$ 12.

9 Voor de goedle orde: "vestiging' wordt in dit geval analoog gebruikt an 'overdracht".

10 Vergelijk Asser/Mijnssen-De Haan 3.1 (2001), nr. 206.

11. Ten behoeve van de helderheid zal ik in de lloofdtekst enkel de westiging van een recht van wruchtgebruik op cen aandeel op naam in de BV bespreken. Mutatis mutandis geldt het geschrevene ook voor aandelen op naam in de niet-beursgenoteerde $\mathrm{NV}$.

12 De wet spreekt over rechten. Welke lidmaatschapsrechten het betreft is voor de bespreking varn de erkenming niet zonder meer van belang. In 86.2 komen de rechten uit vennootschapsrecht van te vruchtgebruiker uitgebreid aan bod. Met betrekking tot de verplichtingen wan de andeelhouder, zoals het wolstorten wan het aandeel en zijn verplichtingen uit hoofde van de blokkeringsregeling, wordt steeds aangenomen dat deze meteen en zonder erkenning wan de vennootschap zijn owcrgegaan. Zie G.M. ter Hurne, diss. RUG (1994), p. 162 alsmede Asser/Maeijer 2-11ll (2000), $\mathrm{nr}_{202}$. Aangenomen mag worden dat zulks eveneens geldt voor vennootschapsrechtelijke verplichtingen van de vruchtgebruiker. 


\subsubsection{Vestigingshandeling: notariële akie}

De regels voor levering van een aandeel op naam in een BV zijn sinds 1 januari 1993 vervat in artikel 2:196." Het artikel vormt een lex specialis ten opzicht wan de regels voor de levering van rechten op naam uit artikel $3: 944^{14}$ Voor de voltooiing van de overdracht is aldus, naast een geldige titel en beschikkingsbevoegdheid op grond van artikel 3:84, levering vereist met als leveringshandeling een notariële akte. De keuze voor het vereiste van een notariële akte in plats van de onderhandse akte; zoals onder de oude wetgeving te doen gebruikelijk was, is gebaseerd op een antal argumenten, walaronder 'het tegengaan van misbruik van BV's' en 'het bevorderen van de rechtszekerheid. ${ }^{15}$ Voor de vestiging van het recht van vruchtgebruik op een aandeel op naam in een $B V$ geldt dientengevolge dat de vestiging haar weerslag moet krijgen in een notariële akte. ${ }^{16}$ De ondertekende notariêle akte is als vestigingshandeling tevens de belichaming van de zakelijke overeenkomst van de vestiging.

\subsubsection{Erkenning en hef aandeethoudersregister}

\subsubsection{Erkenning van de vestiging}

Met het verlijden van de akte is de vestiging van het recht van vruchtgebruik op het aandeel voltooid en is de rechthebbende niet langer bij uitsluiting bevoegd de rechten die met het aandeel gepaard gaan, uit te oefenen. Het eerste lid van artikel 2:196a stelt dat de levering van een aandeel op naam of levering van een beperkt recht ${ }^{17}$ daarop mede van rechtswege werkt tegenover de vennootschap: De bepaling bewerkstelligt in het kader van overdracht van een aandeel dat de vervreemder zijn rechten uit het aandeelhouderschap verliest. De verkrijger is door de overdracht formeel eigenaar geworden van het aandeel, maar hij is op grond van de werking van artikel 2:196a nog niet toegelaten tot zijn rechten als aandeelhouder. Hiervoor is erkenning door de betrokken vennootschap vereist. In aansluiting op de erkenning wordt door het bestuur van de vennootschap het aandeelhoudersregister gewijzigd om de nieuwe eigendoms- en lidmaatschaps-verhoudingen weer te geven. ${ }^{18}$ In het kader van het vestigen van een recht van vruchtgebruik is de vraag of en in hoeverre erkenning deel uitmaakt van de vestiging.

13. Het woor sen andeel op nam in een miet-beurgenoteerde NV geldende art. $2: 86$ is identiek ana art. 2: 196

142 Z voor een overzicht wan de roerige ontstansgeschiedenis van deze regeling Ter Hunme, diss. p. $137-141$.

15. Kamenstaken If 1991-1992, 21155, ni: 17, p. 3.

16. AssorMacijer 2-III (2000), n. 201; Van Schilfgarde/ Wnter (2003), nr. 40.

17. Zie yoor deze taaltechnische onvolkomenheid voenoot 8 .

18. Art. $2: 194 \mathrm{lgg}$ het bestur wan de vennootschap de verplichting op het aandeelhoudersmegister bij to houden. Aangezien te BV geen aandew bewajza mag uigeven (art. 2: 1.7 lid 1), vornt dit andeelhoudersnegister het bewijs van aandeehouderschap in de BV. Bovendien verplicht bet artikel ook de beperkte rechten op aandelen in de BV in het andeelhoudersregister. op te nemen. 
Vooreerst dient geconcludeerd te worden dat de erkenning géén deel uitmaakt van de vestiging. ${ }^{19}$ In beginsel kan de vruchtgebruiker er woor kiezen de vestiging niét te laten erkennen door de vennootschap. ${ }^{20}$ De situatie van de vruchtgebruiker is daardoor niet zonder meer vergelijkbaar met die van de verkrijgende aandeelhouder. Daar waar deze nieuwe aandeelhouder al zijn aanspraken uit aandeelhouderschap pas na erkenning kan effectueren, is de vruchtgebruiker niet aangewezen op de erkenning voor het uitoefenen van al zijn rechten. De rechten uit vruchtgebruik komen hem immers uit hoofde van het goederenrecht reeds toe. Meer in thet bijzonder is de wruchtgebruiker gerechtigd tot de vruchten van het aandeel. Zodra de vordering tot uitbetalen van dividend opeisbaar is geworden; moet de vruchtgebruiker geacht worden rechthebbende te zijn van deze vordering. ${ }^{21}$ De vennootschap, als schuldenaar van deze vordering, is echter (nog) niet op de hoogte van het bestaan van de vruchtgebruiker als rechthebbende van het dividend. Wanneer de vennootschap het dividend aan de bezwaarde aandeelhouder uitbetaalt moet deze betaling bevrijdend geacht worden ${ }^{22}$ De vrucht, te weten de vordering uit dividend, gaat daardoor teniet voor de vruchtgebruiker. Van directe verkrijging ex artikel 3:110 van deze vordering op naam kan, zoals reeds besproken, geen sprake zijn. ${ }^{23}$ De aanpalende regels van verpanding bieden in dit geval evenmin - voldoende - soelaas. ${ }^{24}$

Wel kan worden aangesioten bij de systematiek van de onlangs ingevoerde cessie zonder mededelingsvereiste. ${ }^{25}$ Vestiging van een recht van vruchtgebruik houdt immers - onder meer - de facto in dat de aandeelhouder zijn (toekomstige) vorde-

19 Aanvankelijk werd woorgesteld de erkenning wél deel uit te laten maken van de constitutieve vereisten voor overdracht van een andeel op naam. Deze relativiteit in de goederenrechtelijke overdracht stuitte echter op te veel kritiek. Zile Ter Huurne, diss, p. 162 en verder: JJ.A. Hamers, diss. RL (1996), p. 29-30. Hier kan reeds aangetekend worden dat de erkenning wel constitutief is voor de bezwaring van een aandeel op naam in een beursenoteerde NV. In $\$ 4.3 .4$ van dit hoofdstuk wordt hieraan aandacht besteed.

20 Vergelijk in dit werband de beweegredenen van de pandhouder om zijn verpanding stil te houden. De pandhouder en/of hoofdgerechtigde kunnen besluiten hun rechtswerhouding niet te openbaren. Een werzoek tot erkenning zou in feite de openbaring van het pandrecht inthouden. Zie Asser/Macijer 2-111 (2000), watr. 201; Ter Futurne, disss, p. 206; Hamens, diss., p. 38.

21 Vergelijk 84, I 4 van hoofdstuk. II. VAN SCHLFGARDE is deze mening eveneens toegedan Hij concludeert dat de aandeelhouder zijn recht op dividend vordert als schuldeiser van de vennootschap. Datardoor treedt hij niet als deelnemer op maar als derde. P: wan Schilfgarde, in: Do dubbelrol in het vennootschapsrech" (1993), p. 32, In voornoemde publicatie besprak VAN SCHLFCMAllibe de jurisprudentie inzake thet recht op dividend wan de aandeelhouder. Dit onderwerp kont uitgebreid aan bod in $\$ 2.2 .2$ wan hoofdstuk VI.

22 Art. $6: 34$ lid 1.

23 Zoals reeds eerder betoogd is het naar huidig Nederlands recht niet mogelijk een vordering op cigen naam te verkrijgen woor een derde. Zie woor de bespreking van deze normatieve verkrijging $\$ 2.6 .3$.

24 Fundamenteel verschil met pand is dat in geval van een (stil) verpande vordering, de pandgever ondanks verpanding nog steeds rechthebbende is van de vordering (PitlorReehuis-Heisterkamp (2001), or. 829).

25 Wet wan 30 juni 2004, , $t$ b. 2004, 314. In werking getreden op 1 oktober 2004 . 
ringen uit dividend cedeert aan de vruchtgebruiker. Voor wat betreft voldoening door de debitor cessus (lees: de vennootschap) aan de cedent (de 'bezwaarde' aandeelhouder) geldt eveneens dat deze voldoening bevrijdend is. ${ }^{26}$ In het geval van faillissement van de cedent, daar waar de goederenrechtelijke kracht wan het recht zijn beslag moet krijgen; komt de cessionaris een boedelschuldpositie toe wanneer de debitor cessus in zijn onwetendheid ná faillissement betaalt. Betaalde hij voor faillissement dan moet de cessionaris geacht worden concurrent schuldeiser te zijn. Voor een bijzondere voorrangspositie is in dat geval volgens de Minister geen plaats:

'Het komt erop neer dat het risico voor de gevolgen van het voor de mededeling gekozen tijdstip voor de cessionaris is. ${ }^{27}$

Wat overblijft is een verbintenisrechtelijke aanspraak op de aandeelhouder. ${ }^{28}$

Geconcludeerd kan worden dat, hoewel de erkenning van de vestiging niet constitutief is voor het toekomen van de goederenrechtelijke rechten aan de vruchtgebruiker, afwezigheid van de erkenning leidt tot verzwakking van zijn goederenrechtelijke aanspraken ten opzichte van de aandeelhouder voor zover deze rechten betrekking hebben op de relatie tussen aandeelhouder en wennootschap. Aangenomen moet worden dat na erkenning de vennootschap slechts bevrijdend kan betalen aan de vruchtgebruiker.

De conclusie luidt voor de vruchtgebruiker lichtelijk anders wanneer men spreekt over de uitoefening van het stemrecht dat hij van de aandeelhouder heeft ontvangen ${ }^{29}$ of de vennootschapsrechtelijke rechten die de vruchtgebruiker uit eigen hoofde toe$k^{k} m^{30}{ }^{30}$. Anders dan bij de rechten uit hoofde van het vrucht-gebruik wordt in dit geval een band met de vennootschap verondersteld. Deze band dient zonder meer, naar analogie van de aandeelhoudersrechten, door middel van de besproken erkenning te worden gesmeed. ${ }^{31}$ Bijgevolg is voor de uitoefening van deze rechten erkenning van de vennootschap vereist. ${ }^{32}$

26 Kamerstaken II $2003-2004,28878$, ni. 5, p. 13.

27 Kanerstukken $1 / 2003,-2004,28.878$, nr. 5, p. 13 . Het betreft opmerkingen van de MwI natar anleiding van de publicatie van V.P.G. de Serière in Ondernemingsrecht 2003/10, p. 377-378.

28 Art. 636.

29 Op woet van art. 2:88/197 lid 2. Zie de bespreking hiervan in 86.2 .1 .

30 Art $2: 88 / 197$ lid 4 . Voor de bespreking van deze categorie rechten verwijs ik naar $\$ 6.2 .2$.

31 In het geval van do wruchtgebruiker zonder stemrecht die tevens geen aanspraak kan maken op cartificathoudersrechten (vargelijk $\$ 6.2 .2$ ) is de erkenning slechts van belang voor de zojuist behandelde uitkering van dividend.

32. Er bestaat enige controverse ontrent de vraagg of de aandeelhouder ná overdracht van het stenrecht maar vóor erkenning van de vestiging zijn stemrecht mag uitoefenen. De conclusic van VISSER volgend, lijkt mij dat in deze tussenliggende periode de aandeelhouder zijn stemrecht niét mag uitoefenen en het stemrecht dientengevolge tijdelijk door niemand kan worden nitgeoefend. Visser, diss., par. 15. 


\subsubsection{Procedure}

De procedure van de erkenning welke benodigd is voor de uitoefening van de aan het aandeel verbonden rechten kent twee varianten. Ten eerste kan de betrokken vennootschap de vestiging schriftelijk erkennen. Daarnaast kan de vennootschap de vestiging stilzwijgend erkennen.

Schriftelijke erkenning door de vennootschap in kwestie kan op drie verschillende wijzen plaatsvinden. De erkenning kan geschieden door middel van:

a) een zodanige verklaring van de vennootschap in de notariële akte van levering; of

b) een aan de vennootschap overlegd afschrift of uittreksel van de akte ${ }^{33}$; of

c) 'spontane' erkenning door de vennootschap. ${ }^{34}$

Ten eerste kan een erkenning reeds in de overdracht zelf zijn verweven wanneer de vennootschap een daartoe strekkende verklaring aanhecht aan de notariële akte. In het geval van overdracht van een aandeel valt te denken aan de situatie waarin de vennootschap zelf partij is bij de overdracht. Betreft de rechtshandeling die erkend dient te worden de vestiging van een recht van vruchtgebruik, dan lijkt de betrokkenheid onwaarschijnlijk. Dit zou immers inhouden dat de vennootschap zelf rechthebbende is op de betrokken aandelen. Hoewel dit juridisch gezien tot de mogelijkheden behoort ligt het niet in de rede dat door de vennootschap gehouden aandelen worden bezwaard.

Ten tweede kan een afschrift of uittreksel van de notariële akte aan de vennootschap worden betekend. ${ }^{35}$ Dit laatste is voor de vruchtgebruiker die actief gebruik wil maken van zijn rechten natuurlijk te prefereren, aangezien niet gewacht hoeft te worden op een actie van de vennootschap. Aan deze actievere houding hangt natuurlijk wel het prijskaartje van de notaris in verband met een extra afschrift of uittreksel alsook voor de inzet wan de deurwaarder. Tot slot kan de vennootschap de levering spontaan erkennen indien zij kennis draagt van de rechtshandeling en er nog niet om erkenning is verzocht. Erkenning geschiedt dan door middel van inschrijving van de verkrijger van het aandeel of het beperkte recht in het aandeelhoudersregister. De inschrijving heeft direct effect. De betrokken vruchtgebruiker kan derhalve meteen gebruik maken van zijn rechten jegens de vennootschap. De vennootschap dient, indien zij uit eigener beweging erkent, de vruchtgebruiker daarvan, door middel van een aangetekende brief, op de hoogte te stellen. ${ }^{36}$ In dit schrijven zal de vennootschap

33 Art. 2:196b lid 1 en 2 .

34 Art. 2:196a lid 2.

35 Art. 2:86b en 196b. Overigens is het gebruik van de term 'erkenning' enigszins misleidend. Hiermec wordt inmers gesuggereerd dat de vernootschap altijd cen actieve rol dient te spelen bij deze rechtshandeling. De erkeming door middel van het betckenen van de akte heeft echter meer het karakter van cen mediedeling.

36 De rechtskracht wan de spontane erkenning is nijet afhankelijk van deze mededeling. Handboek NW/BV (1992) par. 179a. 
de vruchtgebruiker alsnog om een afschrift of uittreksel van de notariële akte verzoeken.

\subsubsection{Vestiging en blokkeringsregeling}

Het vestigen wan een recht van vruchtgebruik valt niêt onder de blokkerings-regeling van artikel 2:195. Bedoeld artikel spreekt immers van de overdracht van aandelen en rept niet van de vestiging van een beperkt recht daarop. Wanneer echter wordt afgeweken van de hoofdregel en de aan het bezwaarde aandeel verbonden zeggensmacht wordt overgedragen aan de vruchtgebruiker moet, in het kader van het bewaken van de beslotenheid, de blokkeringsregeling worden geëerbiedigd. Artikel 2:197 lid 3 geeft hiervoor een regeling. Die regeling zal besproken worden in hoofdstuk $6^{37}$ in het kader van het stemrecht.

\subsection{Aandeel op naam in een beursgenoteerde NV}

\subsubsection{Inleiding}

Hoewel men bij een NV die aandelen ter beurze noteert niet licht zal denken aan het bestaan van aandelen op naam behoort de uitgifte van een dergelijk aandeel door een NV wel degelijk tot de mogelijkheden. De overdracht en bijgevolg de vestiging van een beperkt recht op een aandeel op naam in dit type vennootschap kent een geheel eigen regime. Sinds 2000 is het mogelijk ook aandelen op naam via het systeem van de WGE over te dragen. ${ }^{38}$ Naast deze specifieke vorm van verkrijging en vervreemding van een aandeel, wordt voor de overige aandelen op naam in een beursgenoteerde NV de regeling van artikel 2:86c voorgeschreven.

Bespreekt men het aandeel op naam in een beursgenoteerde NV dan is het goed te beseffen dat wan deze mogelijkheid vaak gebruik gemaakt wordt om bepaalde bijzondere soorten aandelen uit te geven ${ }^{39}$ Hierbij moet in het bijzonder gedacht worden aan preferente en prioriteitsaandelen. ${ }^{40}$ De preferente aandelen kennen een spe-

37 De overdracht wan stemecht in een NV is geregeld in art. 2:88 lid 3. De bespreking vary de betnokken regelingen is terug te vinden in 82.1 wan hoofdstuk 6 .

38 Wet van 2 novembet $2000, S t b .2000,485$. Her betret thier niet álle alandelen op nam in een beurs

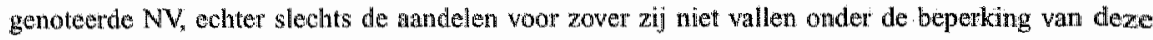
soort in artikel $8 \mathrm{a}$ Wore.

39 Vergelijk hiervoor tevens Van Schilfgaarde/Winter (2003), nr. 34.

40 Een korte bespreking van deze twee bijzondere soorten aandelen is hier geplaatsit, omdat zij eem prominentere rol spelen bij de betusgenoteerde vennootschap dan bij de niet-beursgenoteerde vennootschap. Dit latste laat zich werklaren door het veelal vennootschapbeschermende karakter dat aan deze aandelen kan worden meegegeven. 
cifieke financiële bijzonderheid die hen krachtens de statuten wordt toegekend: Veelal komt dit neer op voorrang bij de uitkering van de winst voor een bepaald percentage van de nominale waarde van het aandeel. " Voor de vruchtgebruiker brengt dit niet veel nieuws. De problemen die rijzen bij de vestiging van een recht van vruchtgebruik op preferente aandelen zijn niet wezenlijk anders van aard dan de problemen bij reguliere aandelen. Eerder kan gezegd worden dat het woor preferente aandelen buiten kijf staat dat het statutair vastgelegde financiële voordeel een vrucht is wan het aandeel en aldus in zijn geheel aan de vruchtgebruiker toekomt. Het element van de voorrang boven reguliere aandeel-houders draagt in dat geval bij aan de zekerheid van de vrucht.

De tweede categorie bijzondere aandelen die met regelmaat in (beurs-) vennootschappen aangetroffen kan worden zijn de prioriteitsaandelen. Prioriteitsaandelen zijn aandelen aan welke volgens de statuten een bijzondere zeggensmacht toekomt. ${ }^{42}$ Waar het aandachtspunt bij het recht van vruchtgebruik op preferente aandelen met name ligt in de sfeer van de vrucht, is het de zeggensmacht die bij het prioriteitsaandeel intrigeert. Bedacht moet worden dat de plaatsing van deze aandelen alles te maken heeft met het uitoefenen van het stemrecht op deze aandelen. De vennootschap zal, meer nog dan bij gewone aandelen, er voor waken de persoon van de aandeelhouder niet uit het oog te verliezen. Het is daarom dat deze aandelen in de praktijk steeds op naam zijn gesteld en de overdracht onderworpen is aan een statutaire blokkeringsregeling. ${ }^{43}$

Het vorenstaande dient voor wat betreft de vestiging van beperkte rechten op zodanige aandelen gerelativeerd te worden. Hoewel beide constructies vooralsnog niet weg te denken zijn uit de praktijk van de beursgenoteerde vennootschappen, dienen genoemde aandeelsoorten dermate specifieke doelen dat het vestigen van beperkte rechten op dergelijke aandelen zoveel mogelijk voorkomen zal worden. Bij beide constructies wordt veelvuldig gebruik gemaakt van stichtingen die de genoemde aandelen houden. Vestiging van een recht van vruchtgebruik door deze stichtingen moet gezien worden als slechts een theoretische mogelijkheid. De aard van prioriteitsaandelen en beschermingspreferente aandelen brengt met zich mee dat deze aandelen niet door natuurlijke personen zullen worden gehouden, laat staan dat zij aan mogelijke vestiging van een recht van vruchtgebruik bloot worden gesteld.

41 Zie Asser/Maeijer 2-111 (2000), mu. 195.

42 Zie Asser/Maeijer 2-111 (2000), wr. 196.

43 Zie Asser/Maeijer 2-III (2000), nr. 196. In de statuten van verschillende statuten van beursgenoteerde vennootschappen is een dergelijke blokkering ten aanzien van prioriteits- en/of preferente aandelen opgenomen. Zie bijlage $A$. 


\subsubsection{Aandeel op naam: artikel $2: 86 \mathrm{c}$}

Wanneer een aandeel op naam in een beurswennootschap ${ }^{44}$ wordt overgedragen is, voor zover het aandeel niet is gegiraliseerd ${ }^{45}$, de lex specialis van artikel $2: 86 \mathrm{c}$ van toepassing, hetwelk een uitzondering vormt op artikel $2: 86^{46}$ Dientengevolge biedt dit artikel tevens de specifieke vestigingshandeling voor een recht van vruchtgebruik op voomoemd aandeel. Voor vestiging is een akte alsmede schriftelijke erkenning van de levering door de vennootschap vereist. Belangrijke verschillen met de zo-even besproken niet-beursgenoteerde vennootschap zijn het ontbreken van de eis van een notariële akte en de toevoeging van de erkenning als constitutief vereiste. De mogelijkheid om als 'stille' vruchtgebruiker ${ }^{47}$ bij dit type vennootschap betrokken te zijn is daarmee onmogelijk geworden.

Evenals de erkenning bij de niet-beursgenoteerde $\mathrm{NV}^{48}$ kan de erkenning op verschillende manieren plaatsvinden. Het minimum aan voorschriften waaraan voldaan moet worden indien de vennootschap geen partij is bij de levering, is een akte met vaste dagtekening. Is de vennootschap wel partij dan voldoet een onderhandse akte zonder vaste dagtekening. ${ }^{49}$ De noodzaak voor de eis van een notariële akte van levering verdween bij de beursvennootschap, omdat men veronderstelde dat malafide vennootschappen sowieso geen beursnotering zouden krijgen (sic). Daar kwam nog bij dat levering door een Nederlandse notaris als erg bezwaarlijk voor de vrije beurshandel werd gezien. Dat de levering van aandelen op naam in beursvennootschappen doorgaans wordt bemoeilijkt door een statutaire blokkeringsregeling speelde hier blijkbaar geen rol. $^{50}$

\subsection{Aandeel aan toonder}

\subsubsection{Inleiding: onafwendbaar afscheid van het toonderbewijs}

Het bewijs aan toonder mobiliseert het aandee $1 .^{51}$ Het toonderbewijs belichaamt de aandeelhouderstechten en maakt het derhalve eenvoudig het aandeelhouderschap als zodanig over te dragen. ${ }^{52}$ Het aandeellhouderschap aan toonder kent in het huidig

44 De beursvennootschap als omschrewen in art. $2: 86 \mathrm{c}$ lid 1.

45 Zie woor eem nadere bespreking van giralisering en te Wo hieronder 4.5 . De lex specialis woor de vestiging van een recht van vruchtgebruik op een aandeel in de WoE wordt besproken in \$4.5.5. De regeling geldt aldus voor zowel een andeel op nam als een aandeel aan toonder.

46 Art 2:86 is het equivalent wan art. $2: 196$ voor de niet-beursgenoteerde $\mathrm{NV}$.

472 ie noot 20 supra

48 Vergelijk hiervoor de bespreking van de erkenning bij de BV in $\$ 4.3 .3$.

49 Zie Ter Huurne, diss., p. 1.93-194.

s0 Ter Huwne, diss, p. 196.198.

51 Handboek NV/BV (1992), par. 175.

52 Assar/Maejjer 2-III (2000), nr. 182. 
rechtsverkeer echter verschillende verschijningsvormen. Het rechtskarakter wan het toonderaandeel als goed is in de loop der jaren sterk veranderd.

In goederenrechtelijke zin is het Klassieke toonderstuk ${ }^{53}$, het aandeel aan toonder, langzaam vervangen door een giraal recht op de betrokken aandelen. Een ontwikkeling die ook wel geduid wordt als de giralisering van aandelen. ${ }^{\text {"4 }}$ RANk-BERENSCHOT kwalificeert dit girale recht op aandelen uit de WGE als een (samengesteld) recht op naam van eigen aard. 5 . VAN DEN HOEK vatte de ontwikkeling van het rechtskarakter van het toonderaandeel als volgt samen:

"Ooit transformeerde het recht van de aandeethouder van een relatief recht naar een absoluut recht. Namelijk naar het absolvte recht van de houder van een toonderpapier. Sluipenderwijs - onder invloed van regels en praktijken om ons heen - voltrekt zich een tweede metamorfose. Het recht van de aandeelhouder ontwikkelt zich weer tot een relatief recht. Ditmaal met absolute trekken. ${ }^{\text {s6 }}$

De eerste stap die werd gezet op weg naar de giralisering van aandelen is de introductie van de CF-stukken in 1964. Het systeem vereenvoudigde de wijze van dividenduitkering aan de aandeelhouders. ${ }^{57}$ Het systeem van de CF-stukken leidde ertoe dat aandelen steeds vaker in bewaring werden gegeven. De bewaargeving van aandelen leidde tot het beruchte arrest "Texeira de Mattos" ${ }^{58}$, waarin het eigendom van nietgeindividualiseerde aandelen voor de betrokken aandeelhouders in een faillissement door oneigenlijke vermenging verloren ging. ${ }^{59}$ Dit probleem van de niet-geindividualiseerde bewaargeving werd in eerste instantie door de markt zelf ondervangen. In 1971 starten verschillende banken het door hen ontwikkelde VABEF-systeem. ${ }^{60}$ In 1977 werd van overheidswege bescherming geboden tegen het risico van "Texeira de

53 Klassieke toonderstukken worden ook wel betiteld als K-stukken.

54 De verwording wan het recht aari toonder tot een giraal recht op naam wordt betiteld als "giralisering".

55 E.B. Rank-Berenschot, in: 'Onderneming en effecten' (1998), p. 162.

56 M.P. van den Hoek, WPNR 6536 (2003), p. 437. In zeer vergelijkbare bewoordingen; M.A. Blom, in: 'Onderneming efl effecten" (1998), p. 185; B.F.L.M. Schim, NTBR 2004/8, p. 384.

57 Handboek NV/BV (1992), par. 176.1; C.As. Uniken Venema, "Effectengira-recht in beweging" (2003), p. 26.

58 HR 12 januari 1968 , NJ 1968, 274 m.nt. HD (Texeita de Mattos).

59 Zie woor een witgebreide bespreking van dit arrest en zijn goederenrechfelijke implicaties; $1 . \mathrm{E}$. Fesevur, NTBR $2001 / 10$, p. 503 an verder.

60 Ook wel het VABEF I systeem. Voor de bespreking wan dit systeem zie 34.5 .42 . Naast VABEF I bestaat nog VABEF II. Dit systeem verwult nog cen rol van betekenis in verband met niet-Wos aandelen yan buitenlandse uitgevende instellingen. Zie Uniken Venema, a.k, p. 101-102. De bespreking van het wruchtgebruik op aandelen in een buitenlandse kapitalvennootschap die aldus gebruik maakt van het VABEF II systeen valt buiten het bestek van dit proefschrift. 
Mattos' door introductie van de Wet giraal effectenverkeer 1977.6i Kort gezegd werden hierdoor de aandelen in depots bij de verschillende instellingen opgeslagen ${ }^{62}$ en de aandeelhouders in de kapitaal-vennootschap werden wan rechtswege houders van een aandeel in de bijzondere gemeenschappen die deze depots onder de WGE vormen. Wederom bestaat hier gevaar voor begripswerwarring. Zowel te zaak die het aandeelhouder-schap in een kapitaalvennootschap belichaamt als de deelgerechtigdheid in de bijzondere gemeenschap van de WGE wordt betiteld als 'aandeel'. In het eerste geval is haar oorsprong vennootschapsrechtelijk, in het tweede geval is dat goederenrechtelijk. UNIKEN VENEMA ${ }^{63}$ kiest daarom in het laatste geval voor het begrip 'mede-eigenaar', waarbij hij zich ervan bewust is dat deze term in wezen ook tekort schiet. ${ }^{\text {64 }}$ Ook de door DEN BOOGERT gebezigde term 'giraal aandeel' bevredigt in goederenrechtelijk opzicht hier niet. ${ }^{65}$ Gezien het feit dat de gemeenschap deelgenoten kent, prefereer ik de termen deelgenoot en deelgerechtigdheid. Waar gesproken wordt van deelgerechtigdheid doel ik aldus op het aandeel in de gemeenschap. Uit de context zal blijken of het hier om het verzamel- dan well het girodepot handelt. ${ }^{66}$

Met de goederenrechtelijke gemeenschapsfiguur werd het risico van 'oneigenlijke vermenging' van niet-geïndividualiseerde aandelen ondervangen. Deze versterkte civielrechtelijke aanspraak en de vervanging van de materiële levering door het stelsel van giraal effectenverkeer vormden samen de tweeledige doelstelling van de WGE $1977 .{ }^{67}$ In 2000 werd de giralisering van aandelen verder doorgezet met de vernieuwing van de WGE, waardoor ook op naam gestelde aandelen in het systeem konden worden opgenomen. ${ }^{68}$ De immobilisatie van aandelen makkte dat het fysieke toon-

61 Hierna WoE 1977. De WGE werd in 2000 gewijzigd. Waar gesproken wordt wan de WGE wordt deze laatste bedoeld, daar zij het vigerende recht bewat. Mocht de WGE van 1977 expliciet worden bedoeld zal gesproken worden van WGE 1977.

62 Men spreekt in dit kader ook wel van het 'immobiliseren' van de aandelen. Immobilisatie is een voorwaarde voor de giralisering. Deze immobilisatie werkte overigens de dematerialisatie in de hand. Nu de opgeslagen bewijzen van aandeel niet meer van hand tot hand hoefcen te gaan verdween de noodzaak van het daadwerkelijk drukken van de verschillende bewijzen. Eerst ging men ower tot het drukken van éen verzanelbewijs voor een groot aantal aandelen. Deze zogenaamde "globals' of "global notes' bewerkstelligden een gedeeltelijke dematerialisatie. De daaropvolgende stap, volledige dematerialisatic, is inmiddels eveneens gezet. De WGe malakt sinds 2000 mogelijk ook rechten op naam op te nemen in de Wok. Van enig fysiek bewijs is in dat geval geen sprake meer. C.E. Uniken venema, "Effectengirowecht in beweging" (2003), p. $29-31$.

63 Uniken Venema, a., w, p. 39)

64 Vergelijk mijn opmerking in \$ I. L van hoofdlstuk II.

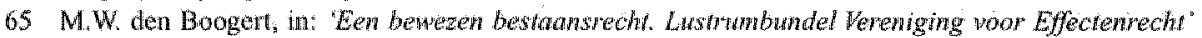
(2002), p. 28.

66 FikLLNK signaleerde eveneens de mogelijke verwarring en lijkt hetzelfde alternatief te hebben werkozen (K. Frielink, WPNR 5945 (1990), p. 36).

67 Kamersukken I/ 1975 - 1976, 13 780, nrs. 1-4, p. 11. Vergelijk E.B. Rank-Berenschot, in: 'Ondesneming en effectem ' (1998), p. 149. UNIKEN WeNEMA spreekt in het kader wan de WGE vain drie hoofdelenenten. Daarbij splitst hij het lastst genoemde doel witeen in 'immobiliseren van effecten" en de 'girale levering van de effecten". (Uniken Venema, $a$ w., p. 13-15).

68 Vergelijk 84.5.5. Art: 8a van de WoE maakt de opname van een NV maam aandeel in het systeem van de WGE mogelijk. 
derbewijs steeds minder werd gebruikt. In plaats daarvan worden de aandelen tegenwoordig vaak 'stukkenloos' uitgegeven, hetgeen wil zeggen dat er in geen enkel stadium sprake is van fysieke bewijzen van aandeel. Dit proces noemt men ook wel dematerialisatie. ${ }^{69}$

\subsubsection{Vestiging}

De invoering van de verschillende systemen die kunnen worden toegepast op de ouderwetse toonderaandelen maken dat de bespreking van de vestiging in complexiteit en diversiteit toeneemt. In deze paragraaf zal ik een werkwijze uiteenzetten om de vestiging van een recht van vruchtgebruik op een toonderaandeel zo helder mogelijk te kunnen presenteren. Eerder is besproken dat de vestiging van een reclitt van vruchtgebruik op grond van artikel 3:98 de regels van overdracht volgt: Dit leidt in het bijzonder tot onderscheid op het punt van de vestigingshandeling ${ }^{70}$ Voor de vestigingshandeling bij aandelen aan toonder moet ten eerste een onderscheid gemaakt worden tussen het aandeel dat enerzijds door de aandeelhouder onmiddellijk wordt gehouden en anderzijds het aandeel dat door de aandeelhouder middellijk wordt gehouden (en derhalve onmiddellijk door een ander wordt gehouden). Heeft de aandeelhouder zelf de feitelijke macht dan levert hij zoals hij een roerende zaak zou leveren. De meest eenvoudige leveringswijze is in dat geval de terhandstelling. De vestigingshandeling komt aldus overeen met de voorgeschreven leveringswijze ( $\$ 4.5 .3){ }^{71}$

Wanneer de aandeelhouder niet zelf houdt maar een ander, bijvoorbeeld de bank of een andere financiële instelling, dan spreekt men in het algemeen van bewaring van effecten. Dit brengt op zijn beurt weer een aantal verschillende toepasselijke wettelijke regimes met zich mee. Blom onderscheidt drie verschillende bewaarsystemen ${ }^{72}$ De eerste twee zijn de geïndividualiseerde bewaring en de niet-geïndividualliseerde bewaring ( $\$ 5.4$ ). Ten slotte onderscheidt hij het bewaarsysteem zoals dat gestalte heeft gekregen in de WGE (\$5.5). De drie systemen en de daarmee overeenkomende wijze van vestiging zullen achtereenvolgens worden besproken.

\subsubsection{Terhandstelling: artikel 3:90 lid 1}

Vestiging van een recht van vruchtgebruik op een aandeel aan toonder lijkt, na raadpleging van de wet, voltooid te kunnen worden door de vruchtgebruiker het bezit te verschaffen van het toonderpapier. Immers, de levering geschiedt dan conform artikel 3:90 lid. Hier treft men echter een dogmatisch en een praktisch probleem aan. Ten

69 Voor eem uitgebreidere bespreking van dematerialisatie wan effecten verwijs ik naar de publicaties van VAN DEN HOEK in WPNR 6504 (2002) welke een reactie vormt op de publicatie van VERAANS over dematerialisatie in WPNR 6495 (2002), alsmede 6567 (2004).

70 Zie $\$ 4.2 .1$

71 Art. $3: 98 \mathrm{j}^{\circ}$ 3:90 lid $\mathbb{1}$ en 3:93.

72 M.A. Blom, Ondernewingsrecht $1999 / 14$, p. 377. 
eerste kan aan de vruchtgebruiker het bezit niet worden verschaft aangezien hij houder moet worden. ${ }^{73}$ Ten tweede stuit men op een navolgend praktisch vennootschapsrechtelijk probleem. Wanneer de hoofd-gerechtigde de vruchtgebruiker het bezit verschaft van het toonderbewijs, is de eerste zijn bewijs van aandeelhouderschap kwijt. Immers van het bezit van het toonderbewijs gaat nu juist de legitimerende functie van thet aandeelhouderschap uit. Zodoende kan hij de rechten die hij (nog) bezit niet uitoefenen, aangezien hij zónder toonderbewijs op de algemene vergadering niet kan aantonen dat hij aandeelhouder is. Dit klemt natuurlijk temeer indien hij voor zich het stemrecht in de aandeelhoudersvergadering heeft behouden. De vruchtgebruiker daarentegen kan zich, door het bezit van het toonderbewijs, in potentie legitimeren als aandeelhouder. Overeenkomstig artikel 3:119 wordt hij immers vermoed rechthebbende te zijn. ${ }^{74}$ Zoals in het algemeen besproken in $\$ 2.2 .1$ lijkt een subtiele wetswijziging voor de hand te liggen om het probleem op te lossen. In aanvulling op de feitelijke machtsverschaffing zonder bezitsverschaffing is een specifieke oplossing voor het uitoefenen van vennootschapsrechtelijke rechten geraden. Nu de verhouding tussen de vruchtgebruiker en de hoofdgerechtigde niet kenbaar is voor de vennootschap, is het voor de laatste immers ondoenlijk te oordelen wie nu over welke vennootschapsrechtelijke rechten beschikt. En omdat het mogelijk is om zonder medewerking of kennisgeving van de vennootschap het stemrecht over te dragen aan de vruchtgebruiker ${ }^{75}$, is de juridische heldetheid voor de vennootschap ver te zoeken. Temeer omdat de vestiging geen belichaming hoeft te vinden in een juridisch document. Dit maakt dat de vestiging van het vruchtgebruik en zelfs de overdracht van stemrecht in dit kader mondeling kan geschieden..$^{76}$

Naast het dilernma dat uit het goederenrechtelijke deel van de vestiging reeds bleek, neemt in het vennootschapsrecht de legitimerende functie van bezit een prominente plaats in. In hoofdstuk 2 betoogde ik dat de regeling van het vruchtgebruik een subtiele wetswijziging behoeft. Het voorstel van Berenschot om de wet in die zin te wijzigen dat voor het vestigen van het recht van vruchtgebruik de zaak 'in de macht van de vruchtgebruiker' dient te worden gebracht, verdient wat mij betreft bijval. ${ }^{77}$ De voorgestelde wijziging kent echter voor wat betreft aandelen aan toonder te ver gaande repercussies. Nuancering is geboden. In dit geval is het te verkiezen de vestiging van een recht van vruchtgebruik gepaard te laten gaan met een (onder-

73 Zie voor de bespreking van dit probleem bij de levering van het recht van vruchtgebruik op cen roerend, nietwregister goed $\$ 2.2 .1$

74 Pitlo/Reehuis-Heisterkamp (2001), nr. 221: 'In bezit is derhalve, terecht of niet terecht, een pretentie van het zijn van rechthebbende gelegen.' Zie uitgebreider ower de 'pretense' aandeelhouder W.C.L. van der Grinten, in: 'Kan wewnootschappelijk belang' (1988), p 51 en verder.

75 Lid 3 van artikel 2:88 bepaalt immers dat in geval van een NV een enkele bepaling hiertoe bij vestiging wolstaat, mits de persoon tot de vrije kring behoort en de statuten deze mogelijkheid niet tegengatan.

76 Art. 2:88/197 geeft immers geen vormwoorschriften ten aanzien van de stemrechtoverdracht.

77 Vergelijk $\$ 2.2 .1 .4$ 
handse) akte. Deze akte kan, parallel aan de notariële akte, uiting geven aan de goederenrechtelijke overeenkomst. De voorgestelde feitelijke machtsverschaffing kan met haar legitimerende functie ten opzichte van de vennootschap gebruikt worden om de stemgerechtigdheid te positioneren. In deze zin kan bij overdracht van stemrecht, welke gepaard gaat met de vestiging, het bezit van het toonderbewijs worden verschaft om uiting te geven aan deze stemoverdracht. De vruchtgebruiker kan aldus zijn stemrecht naar eigen inzicht uitoefenen in de AvA. Omgekeerd kan de aandeelhouder, met de akte van vestiging in de hand, de rechten uitoefenen die hem ondanks de vestiging en de stemoverdracht nog steeds toekomen. ${ }^{78}$

Blijft het stemrecht bij vestiging van het vruchtgebruik in handen van de aandeelhouder dan is het mijns inziens zinvol een en ander om te keren. De aandeelhouder behoudt het bezit van zijn toonderbewijs en hij levert het vruchtgebruik aan de vruchtgebruiker door middel van de onderhandse akte. Deze akte kan de vruchtgebruiker gebruiken voor zowel de uitoefening van de hem eventueel toekomende rechten krachtens artikel 2:88 lid 4 als voor het verkrijgen van de vrucht. Door de akte te betekenen aan de vennootschap is de vennootschap op de hoogte van de gerechtigdheid van de vruchtgebruiker op de vordering uit betaalbaarstelling van dividend. ${ }^{79}$

Voor wat betreft de invulling van deze akte kan aansluiting gezocht worden bij zowel de boedelbeschrijving van artikel 3:205 als de onderhandse akte bij cessie. De verplichting om in tegenwoordigheid van de hoofdgerechtigde een boedelomschrijving te maken rust reeds op de vruchtgebruiker en biedt bovendien mogelijkheden om genoemde bijzonderheden op te nemen. ${ }^{80}$ Daarnaast kan aansluiting gezocht worden bij de onderhandse akte welke benodigd is voor de cessie van artikel $3: 94 .^{81}$

\subsubsection{Bewaargeving}

\subsubsection{Geïndividualiseerde bewaargeving: traditio longa manu}

Wanneer een bewaarnemer het aandeel op individualiseerbare wijze ${ }^{\$ 2}$ voor de aandeelhouder houdt, kan de levering in het kader van de overdracht niet door middel

78 De aandeelhowder behoudt na overdracht wam het stemrecht immers zijn overige aandeelhoudersrechten: Vergelijk hiervoor de bespreking in $\$ 6.2 .7$.

79 Vergelijk woor wat betreft deze betekening de overwegingen in \$4.3.3.1.

80 Art. 3:205 lid 2. Vergelijk in dit verband $\$ 2.5 .2 .1$.

81 Daarbij kan men gezien de inwoering vain de cessie zonder mededelingsvereiste in ditzelfde artiket de parallel naar deze vorm van overdracht wan een wordering verder doortrekken. Een 'stil wruchtgebrnik' waarbij de aandeelhouder zijn stemrecht behoudt en de vestiging aldtus geschiedt door middel van een authentieke of geregistreerde vruchtgebruiker is mijin inziens voorstelbaar. De wruchtgebruiker werschijnt in deze situatie pas op de radar wan de vennootschap wanneer hil zijn wruchtgebruik 'openbaart'. 'Stil' houdt woor de vruchtgebruiker wel in de witsluiting wan uitoefening van stemrecht of andere lidmatischapsrechten.

82 Bij 'op individualiseerbare wijze' kan in dit geval gedacht worden aan het fysiek apart houden van bet toonderbewijs of een systeem van nummerregistratie. Asser/Mijnssen-De Haan 3il (2001), nr. 93; Pitlo/Reehuis-Heisterkamp (2001), nur. 226; Snijders-Rank-Berenschot (2001), nr. 171 
van bezitsverschaffing geschieden. Immers, niet de rechthebbende van thet aandeel heeft de feitelijke macht, maar de bewaarnemer. De overdracht wordt in een dergelijk geval voltooid door een levering longa manu. ${ }^{83} \mathrm{De}$ (onmiddellijk) houder woor de vervreemder, wordt op grond van een tweezijdige verklaring (onmiddellijk) houder voor de verkrijger. Toegepast op de individuele bewaar-geving wordt de bewaarnemer voor de ene aandeelhouder/vervreemder, na levering longa manu bewaarnemer voor de ander/verkrijger Om de bezitsoverdracht als gevolg van de tweezijdige werklaring rechtskracht te geven dient de overdracht aan de houder te worden medegedeeld. De wet stelt aan deze mededeling geen vereisten. Voor de vestiging van het recht van vruchtgebruik op een in bewaring gegeven toonderaandeel kan dus op voet van de hierboven geschetste regeling worden volstaan met een tweezijdige verklaring en een mededeling aan in dit geval de bewaarnemer. ${ }^{\$ 4}$

\subsubsection{Niet-geindividualiseerde bewaargeving: het $\mathrm{VABEF}^{85}$-systeem}

De niet-geindividualiseerde bewaargeving is als systeem evident niet gericht op het voorkomen van het rechtsgevolg zoals dat in 'Texeira de Mattos' intrad. De in bewaring gegeven aandelen gaan juist door vermenging behoren tot het vermogen van de bewaarnemer. In tegenstelling tot de WGE, waar deze goederenrechtelijke angel wordt verwijderd, richt de bewaargeving zich op het voorkomen van de situatie waarin 'de belegger uit de casus van 'Texeira de Mattos' uiteindelijk verkeerde, namelijk het faillissement van de bewaarnemer. In 1971 wordt door banken het reeds genoemde VABEF-systeem ingevoerd. ${ }^{86}$ Kort gezegd hield het systeem in dat een rechtspersoon werd opgericht (het zogenaamde VABEF-bedrijf) welke onafhankelijk van de bank opereert. ${ }^{87}$ Hij is eigenaar van de in bewaring genomen effecten en de belegger krijgt een obligatoire aanspraak jegens het bedrijf ter zake van levering van enkel naar soort bepaalde effecten. Opgemerkt zij dat hoewel door de overdracht de goederen-

83 Art. 3:84 jo 3:90 en 3:115 sub c. Zie ook K. Frielink, WPNR 5944 (1990), p. 20.

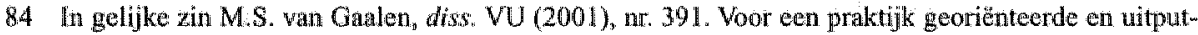
tende bespreking wan deze vruchtgebruikworm zie Frielink, a. w. , 5.23 en volgende.

85 Vereenvoudigde Administratie en Bewaring van Effecten.

86 C.A. Uniken Venema "Effectenghorecht in beweging" (2003), p. 22; E. B. Rank-Bierenschot, in: "Ondernewing en effectew" (1998), p. 149-150 alsmede, nitgebreider, W.R. Meijer, diss. KUN (1974), p. 42 en verder; W.A.K. Rallik, in: 'Bhenaring en elgendom wan effecten' (1997), p. 58 en volgende. Het verwante VABEF II-systeem wordt door Rank eveneens besproken (p. 62 en verder). Tegenwootdig kent alleen het VABEF II-systeem nog betekenis in de praktijk. Het oorspronkelijke WABEF-bedriff dat zich richtte op de bewaaneming wan toonderaandelen is, vanwege het feit dat het toondersysteem langzamaan geintegreerd is in de WGE, een zeldzaamiheid geworden. Naar verwachting zal het oorspronkelijke VABEF-bedrijf geheel verdwijnen. Het systeem is echter nog springlevend in het WABEF II-bedrij. Dit systeem draagt zorg woor effecten op naam en buitenlandse effecten. Het is niettemin op dezelfde leest geschoeid als zijn voorganger en de bespreking in dit proefschrif zal derhalve het VABEF-systeem in zijn algemeenheid adresseren.

87 Het VABEF -bedrijf kreeg als rechtsworn de kapitaalwentiootschap. De aandelen in deze kapitaalvennootschap(pen) werden door de bank(en) owergedragen aan stichting en zodoende werden de VABEF-bedrijuen "ontdochterd'. Uniken Venema, aw, p. 22-23. 
rechtelijke band wan aandeel en aandeelhouder is doorbroken, daarmee niet alle andeelhoudersrechten zijn overgedragen. Zeggenschap en economisch belang blijven op grond van de bewaarovereenkomst bij de belegger berusten. ${ }^{88}$ De afwezigheid van de goederen-rechtelijke aanspraak wordt gecompenseerd door het zoveel mogelijk vermijden van risico door het $\mathrm{VABEF}$-bedrijf. ${ }^{9}$

$\mathrm{Nu}$ geconcludeerd is dat het bovengenoend systeem het VABEF-bedrijf eigenaar maakt, valt moellijk in te zien hoe aandelen die op dergelijke wijze in bewaring zijn gegeven kumen worden bezwaard met een beperkt recht. Immers de aandeelhouder is geen rechthebbende meer en kan aldus niet meer voor de bezwaring van zijn aandeel zorg dragen. Waren de aandelen reeds bezwaard voordat zij in bewaring waren gegeven, dan zal de overdracht of de oneigenlijke vermenging een einde maken aan het bestaan van het vruchtgebruik. Is het VABEF-bedrijf te goeder trouw dan maakt de derdenbescherming van art. 3:86 lid 2 reeds een einde aan het vruchtgebruik bij de overdracht. Wanneer het VABEF-bedrij daarentegen wel op de hoogte is dan zal, op voet van het arrest "Texeira de Mattos", de oneigenlijke vermenging het recht van vruchtgebruik teniet doen. Wat resteert is de mogelijkheid om de vordering die de belegger op het VABEF-bedrijf heeft aan de vruchtgebruiker in vruchtgebruik te geven. $^{90}$ Zulks betreft strikt genomen echter niet langer een vruchtgebruik op een aandeel, maar een recht van vruchtgebruik met als object de genoemde obligatoire rechtsverhouding.

\subsubsection{Het systeem van de WGE}

\subsubsection{De WGE: algemeen}

De WGE vormt in veel opzichten de vreemde eend in de bijt van dit hoofdstuk. De WGE kan gezien worden als een door de wetgever in het leven geroepen bijzondere vorm van bewaargeving. Alvorens in te gaan op de vestiging van een recht van vruchtgebruik op een aandeel welke opgenomen is in het systeem van de WGE, dient kort aandacht besteed te worden aan voornoemd systeem en zijn complexe structuur. $^{\text {gI }}$ Voor wat betreft de goederenrechtelijke aanspraken op de achter-liggende aandelen werd door de wetgever destijds gekozen voor de goederenrechtelijke gemeenschap. De WGE is daarnaast gestructureerd in drie lagen, een structur die als piramidaal $^{22}$ omschreven kan worden.

88 Meijer, diss., p. 45

89 De statutaire doelomschrijwing van het WABEF-bedrijf stelt dat enkel de bewaring wan effecten het

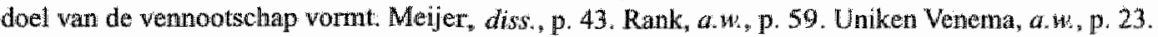

90 Mits deze vordering overdraagbaar is. Vergelijk \$2.1.2. van boofdstuk II.

91 Vergelijk voor een diepgravende analyse van de structuur van de WGa: C.AE. Uniken Venema, 'Effectengiromecht in beweging' (2003), p. 35 en verder alsook E.B. Rank-Berenschot, in: 'Ondet' neming en effecten' (1998), p. 149 en volgende.

92 Haentjens, $a . w$, p. 473. 
De bovenste laag wan de piramide wordt gevormd door Euroclear Nederland ${ }^{93}$. Euroclear is het centrale instituut dat elk girodepot beheert. ${ }^{94}$ Elk depot bevat alle effecten van een bepaalde soort die bij het centraal instituut berusten. ${ }^{95}$ Bijgevolg bestaan er evenveel girodepots als soorten effecten. ${ }^{96}$ Het girodepot is een bijzondere gemeenschap waarvan de deelgerechtigdheid op naam staat wan de aangesloten instelling. ${ }^{97}$ De aangesloten instelling ${ }^{98}$ vormt de tweede laag van de WGE en is op haar beurt de beheerder van het verzameldepot ${ }^{99}$ Tot dit verzameldepot behoort ten eerste de deelgerechtigdheid van het girodepot. ${ }^{100}$ Bovendien vallen effecten die de aangesloten instelling houdt ${ }^{101}$, alsmede de deelgerechtigdheid van deze aangesloten instelling in het verzameldepot met dezelide soort effecten van een andere aangesloten instelling. ${ }^{102}$ Deelgenoten in het verzameldepot vormen de uiteindelijke aandeelhouders in de kapitaal-vennootschap: de beleggers. ${ }^{103}$

\subsubsection{De WGE: goederenrechtelijke aspecten ter discussie}

De keuze voor de gemeenschap als goederenrechtelijke basis voor het effectenverkeer vloeit direct voort uit het 'Texeira de Mattos'-arrest. Door de belegger naar rato van zijn inbreng deelgenoot te maken van de gemeenschap waartoe zijn effecten behoren werd het euvel van 'oneigenlijke vermenging' geëcarteerd. Het goederenrechtelijke lot van de belegger is zodoende niet meer onlosmakelijk verbonden met het lot (of de gebrekkige administratie) van zijn bank. Hoewel de keuze alleszins nobel is, stond zij vanaf het begin bloot aan kritiek. ${ }^{104}$ De welhaast krampachtige

93 Hierna: Euroclear. Sinds 31 januari 2004 gat het Nederlands Centraal Instituut woor Giraal Effectenverkeer (Necigef) B. W. in de praktijk door het leven als. Euroclear Nederland. Euroclear Nederland is een volledige dochter van Euroclear Bank SA/NV. De statutaire naam is overigens ongewijzigd gebleven.

94 Art. 34 en 36 WGE. Uit hoofde van deze positie is Euroclear Nederland de zogenaamde CSD (Central Securities Depository). De moedermaatschappij wan Euroclear Nederland te weten Euroclear Bank SA/NV is de ICSD (International Centrial Securities Depository).

95 Art. 35 sub ia Wors.

96 Art. 34 en 35 WGa.

97 Art. 38 Wor.

98 Art. 1 . 4 Wois. Aangesloten instellingen betreffen veelal banken.

99 Ook in gewal van het werzameldepot betreft het uitsluitend eén soort effecten. Art: 9 lid 2 WoE.

100 Art, 10 sub o Wor

101 Het gedeelte van het verzanneldepor dat bestaat wit eigenlijke effecten wordt ook wel aangeduid als "het voordepot". C.A. Uniken Venema, 'Effectenginorechn in beweging' (2003), p. 35.

102 Respectievelijk art. 10 sub a en $b$. WOE. In het laatste geval is de aangesloten instelling te vergelijken met een 'gewone' belegger. Het deel onder b noemt men ook wel het nostro-bestand.

103 Zuiver gesproken is het niet juist te spreken van aandeelhouder (in vennootschapsrechtelijke zin). Bovendien omvat het begrip effecten zoals gezegd in ieder geval meer dan aandelen alleen: Daar whar de madruk van de juridische positie van de deelgerechtigde/aandeelhouder komt te liggen op het vennootschapsrechtelijke gedeelte zal ik spreken van de "belegger".

104. Meest in het oog springend is de kritiek wan Schoordijk die in een publicatie over het voorontwerp in 1975 reeds zijn twijfels stelt bij de "levering" van aandeel in een verzameldepot en haar goederenrechtelijk achtergrond. H.C.F. Schoordijk, WPNR 5316 (1975), p. 633 en verder. 
manier waarop de WGE vasthoudt aan haar goederenrechtelije oorsprong wordt mijns inziens terecht veroordeeld door verschillende schrijvers. De discussie speelt zich in wezen af op twee afzonderlijke fronten. Enerzijds ondervindt de 'levering ter opname" uit artikel 12 lid 1 veel kritiek. ${ }^{105}$ Daarnaast staat de toepasselijkheid van de regels van overdracht op artikel 17 van de WGE ter discussie. ${ }^{106}$ De regeling van artikel 17 W Ge heft het karakter van een bijschrijving in plaats van een overdracht $e x$ artikel 3:84. De bijschrijving ex artikel 17 WGE - alsmede de 'overdracht" tussen aangesloten instellingen ex artikel 41 WGE - vormen, naar de mening van geciteerde schrijvers, door de WGE gecreëerde bijzondere wijzen van originaire verkrijging. ${ }^{107}$ Originaire verkrijging houdt voor de verkrijger in dat het goed vrij van beperkte rechten wordt verkregen. Eventuele, door de vervreemder gevestigde, beperkte rechten gaan dientengevolge teniet. ${ }^{10 \$}$ Op deze manier lijkt de goederenrechtelijke bescherming die de deelgenoot wordt geboden aan de beperkt gerechtigde te worden onthouden.

\subsubsection{De WGE: vestiging krachtens artikel 23}

De vestiging van het vruchtgebruik op aandelen in de WGE valt op door haar eenvoud. De deelgerechtigdheid van de witeindelijke aandeelhouder in het verzameldepot wordt ingevolge artikel 23 WGE bezwaard met het recht van vruchtgebruik door middel van bijschrijving - de vestigingsformaliteit - ten name van de vruchtgebruiker in de administratie van de aangesloten instelling. Mitsdien is de vestiging, indien de tevens benodigde beschikkingsbevoegdheid en titel voorhanden waren, door bijschrijving voltooid. Vaststaat dat het goed dat bezwaard wordt de deelgerechtigdheid in het verzameldepot betreft en uitdrulkkelijk niet de goederen die deel uitmaken van deze gemeenschap. ${ }^{109}$

Naast de regeling van de vestiging in artikel 23 WGE dient gewezen te worden op de regelingen van artikel 12 lid 1 (slotzin) en artikel 31 van de WGE. De artikelen vormen in zekere zin het spiegelbeeld van elkaar. De slotzin wan artikel 12 lid 1 WoE biedt een regel van substitutie. Wanneer zich onder de in bewaring gegeven effecten

105 Vergelijk onder andere L.D. van Setten, in: "Zekerheid in wencthde zaken en rechten" (2003), p. 100 en wolgende alsook Uniken Venema, a. H. $^{2}$, 191 en verder.

106 Zie onder andere B.F.L.M. Schim, in: 'Onderneming en 10 jaat" wheuw burgerlijk recht" (2002), p. 193 en verder en in Ondernemingsrech $2004 / 11$, p. 418 en volgende; J. wan der Bcek, Onder. nemingsrech $2003 / 7$, p. 244 en verder; M.P. wan den Hoek, WPNR 6536 (2003) en diens reactie op VAN DER BEEK's publicatie in Ondernemingsrecht 2003/12, p. 464 en wolgende en ten slotte de reeds geciteerde HAENTuENS in WPNR 6582 (2004), p. 472 en verder en de daarop volgende reactie van Biemans en Schim in WPNR 6602 (2004), p. 986 en verder. Aunders: W. Snijders, WPNR 6608 (2005), p. 95.

107 B.F.L.M. Schim, in 'Ondernening en 10 jaor nieww burgerlijk rech"' (2002), p. 198-199; Van der Beek, a.w, P. 245-246 en kennelijk ook Taentjens, $a, w$, p. 479.

108 In gelijke zin Van der Beek, aw, p. 246 en B.F.L.M. Schim, Ondernemingsrech 2004/11, p. 423.

109 Vergelijk art. 16 lid $\|$ en 2 Woll, alsook Schim, $a$.w., p. 419 
bezwaarde effecten bevinden, komt dit beperkte recht op de deelgerechtigdheid te rusten. Andersom stelt artikel 31 WGE dat wanneer effecten uit hoofde van een bezwaarde deelgerechtigdheid worden uitgeleverd, deze uitgeleverde effecten eveneens bezwaard zijn met een recht van vruchtgebruik.

\subsubsection{De goederenrechtelijke positie van de vruchtgebruiker op een aandeel in de WoE}

Hoewel de vestiging van een vruchtgebruik op een aandeel in een verzameldepot door een eenwoudige pennenstreek van de wetgever in het leven is geroepen, is daarthee geenszins de goederenrechtelijke positie van de vruchtgebruiker verklaard. Hierboven is reeds geconcludeerd dat bij vervreemding van voornoemde deelgerechtigdheid door de aandeelhouder het beperkte recht - in ieder geval voor wat betreft het vervreemde deel - verdwijnt. De deelgerechtigdheid die de verkrijger toekomt wordt immers originair verkregen. Daarnaast is geconcludeerd dat de overdracht als beschikkingshandeling in de WGe geen plaats kent. Aangesloten wordt bij de regels van het girale betalingsverkeer.

Maatgevend voor de goederenrechtelijke positie van de vruchtgebruiker is de positie van diens deelgenoot. Dat deze deelgenoot over een deel van zijn aandeel kan beschikken volgt uit artikell 16 lid 1 tweede zin van de WGE:

'Hij [de deelgenoot, ECB] kan ook beschikken over een gedeelte van zijn aandeel, voor zover daardoor geen aandelen ontstaan die overeenkomen met een of meer effecten."

Vervreemding van een deel van zijn deelgerechtigdheid betekent voor de deelgenoot dat zijn deelgerechtigdheid met het daarmee corresponderende deel wordt verkleind. Vervreending door de deelgenoot houdt aldus goederenrechtelijk in het krimpen van de deelgerechtigdheid in het verzameldepot. Omgekeerd betekent aankoop van dezelfde" pot. Object van het recht van vruchtgebruik wordt in dit geval gevormd door deze deelgerechtigdheid. Nu het recht van vruchtgebruik juist op de deelgerechtigdheid rust kent het vruchtgebruik een zelfde elasticiteit als de deelgerechtigdheid zelf. Voor zover een deelgerechtigdheid blijft bestaan - voor zover dus niet de deelgerechtigdheid in zijn geheel wordt vervreemd - 'krimpt' en 'groeit' het recht van vruchtge-

110 De bijzin voorkont dat breukdelen wan effecten ontstaan en als gevolg daarvan éen effect meerdere rechthebbende zou kennen (daarnee weer een nieuwe eenwoudige gemeenschap creërend). Kanterstukken $I I 1975-1976,13780$, nrs. $1-4$, p. 36 .

111 Op voet van art: 9 lid 2 (alsmede art. 34) Wois betreft de deelgerechtigdheid telkens én bepaalde soort effecten. 
bruik naargelang de deelgenoot verkoopt dan wel koopt. ${ }^{12}$ Zulks gaat echter niet op indien ardere effecten worden verkregen. In dat geval dient het recht van vruchitgebruik opnieuw op deze nienwe deelgerechtigd-heid te worden gevestigd.

Wanneer de deelgenoot zijn volledige deelgerechtigdheid in een bepaald soort aandelen vervreemdt, verdwijnt daardoor het recht van vruchtgebruik op dit goed. Verwerft de deelgenoot nieuwe effecten van een andere soort dan werkrijgt hij op originaire wijze een deelgerechtigdheid in het desbetreffende verzameldepot. Deze deelgerechtigdheid is onbezwaard. VAN DER BEEK heeft in het kader van het pandrecht op aandelen in de WGE betoogd dat een regel van substitutie erwoor moet zorgen dat ook de nieuw verworven effecten, bij voorafgaande vervreending van andere (soort) effecten door de belegger, bezwaard zijn met een recht wan pand ${ }^{113}$ SeHIM relativeert het door VAN DER BEEK geschetste probleem en stelt dat de pandhouder kan voorkomen dat de belegger vervreemdt door de rekening van de laatste te blokkeren. ${ }^{1 / 4}$ Een dergelijke relativering gaat voor het vruchtgebruik niet op nu zij het doel van zekerheid niet met het pandrecht deelt en een dergelijke blokkering de belegger onnodig in zijn bevoegdheden beperkt. De vruchtgebruiker zou in dat geval buitengewoon gebaat zijn bij een additionele regel van substitutie.

\subsubsection{De vennootschapsrechtelijke positie van de vruchtgebruiker}

op een aandeel in de WGE

Naast de goederenrechtelijke rechtsbetrekking van de vruchtgebruiker en de aandeelhouder tot het WGE-aandeel, dient ook de vennootschapsrechtelijke rechtsbetrekking voor het voetlicht te komen. Uit het voorgaande blijkt dat de goederenrechtelijke band tussen zaak (aandeel) en eigenaar (aandeelhouder) door de WGE is doorgesneden. Daarmee is het toonderbewijs als belichaming van het aandeelhouderschap verloren gegaan. ${ }^{115}$ Hoe wordt de belegger nu in de gelegenheid gesteld om van zijn aandeelhoudersrechten gebruik te maken, warneer de legitimerende functie van het toonderbewijs teniet is gedaan?

112 Een eenvoudige parallel kan getrokken worden met het recht wan hypotheek op een liuis. De alanbouw aan het huis laat het zekerheidsrechn groeien in onwang.

113 Van der Beek, $a .1 \%$, p. 246 en 247. Althans zo begrijp ik zijn navolgende zinsuede: 'Er zou een zaaksvervangingsbepaling opgenomen kunnen worden op grond warwan een beperkt recht dat door overboeking tenietgaath, Komt te rusten op het Wok-aandeel dat wordt verkregen." Immers, wanneer men zou aannemen dat met de verkrijger bedoeld wordt, degene die de deelgerechtiggdheid (waarover beschikt wordt) verkrijgt, betekent zulks dat een willekeurige verkrijger een bezwaard aanded verkrijgt. Naar ik veronderstel is dit niet wat Van Beek beoogt. Een pandrecht op hetgeen in de platsts treedt (en aldus verkregen wordt) voor het vervreende Wo-alandeel houdt de relatie pandgever pandlouder daarentegen intact.

114 B.F.L.M. Schim, Ondernemingsrech 2004/I1, p. 423.

115 Zulks geldt overigens a fortiori voor de in de WGE opgenomen aandelen op naam, aangezien geen toonderbewijzen worden nitgegeven. 
De aangesloten instelling is als beheerder van het verzameldepot belast met het beheer van het depot. ${ }^{166}$ Hoewel de aangesloten instelling expliciet is uitgesloten van het uitoefenen van enkele inspraakrechten op de door haat gehouden effecten ${ }^{11}$, bestaat voor haar de actieve zorgplicht on de deelgerechtigde in staat te stellen van het stemrecht op de effecten gebruik te maken. ${ }^{18}$ In de praktijk nemen de beurs-NV's veelal genoegen met een verklaring van de bank dat de rekeninghouder rechthebbende is van - en dus stemgerechtigd op - $\mathrm{x}$-aantal aandelen. ${ }^{119}$ Een expliciete regeling voor de stemgerechtigde vruchtgebruiker ontbreekt ten enenmale. GORTER en NAKAD pleitten er in dit kader weliswaar voor de zorgplicht te richten op degenen die beschikkingsbevoegd is, maar naar mijn smalk dekt deze oplossing niet de lading. ${ }^{120}$ Immers, zulks veronderstelt dat het pakket rechten slechts een van beide aangaat. Aangenomen dat voor de vestiging van het recht van vruchtgebruik de bijschrijving in de administratie van dezelfde aangesloten instelling volstaat, is een praktische verklaring in het kader van het vruchtgebruik voorstelbaar. De wruchtgebruiker verzoekt een verklaring van de bank waaruit blijkt dat hij stemgerechtigd is op het aantal aandelen waarvoor zijn vruchtgebruik is bijgeschreven. Daarnaast kan de aandeelhouder een verklaring verzoeken op grond waarvan blijkt dat hij hoofdgerechtigde is en aanspraak kan maken op - hem eventueel toekomende - certificaathoudersrechten. Deze constructie suggereert echter wel dat de bijschrijving tevens een aantekening betreffende de stemoverdracht aan de vruchtgebruiker behelst.

Naast de zojuist voorgestelde praktische regeling stem ik bovendien in met de voorstellen die UNIKEN VENEMA in het kader van de inspraakrechten formuleert. Ten eerste stelt hij voor de categorie rechten waarover de aangesloten instelling als beheerder niet mag beschikken ruimer op te stellen. Op die manier wordt een meer omvattend criterium gegeven voor de eventueel aan de aandeelhouder of vruchtgebruiker toekomende inspraakrechten. ${ }^{121}$ Deze wijziging kan voor wat betreft de vruchtgebruiker gepaard gaan met een aantekening daartoe in de bijschrijving.

116 Art. 11 WGE. Parallel hieraan is Euroclear Nederland belast met het beheer van het girodepot. Art. 36 WGIs.

117 De verzamelterm "inspraakrechten" kont van UnfkEN VENEMA. Uniken Venema, a.w, p. 92. Het betreft het recht op bijeenroeping van de vergadening van aandealhouders, het recht het woord te voeren op deze vergadering, het uitoefenen van het stemrecht en het recht van enquête ex art, 2:345. Zie hiervoor lid 3 van art: 11 WoE.

118 Art. 15 Wor. Wederom rust een vergelijkbare ondersteunende verplicliting op de schouders van Euroclear Nederland ex art. 39 WGE.

119 M.W. den Boogert, in: Een bewezen bestaansrecht. Lastrumbindel Vereniging woor Effectenecht" (2002) \& p. 29.

120 D. Gorter en H. Nakad, TVE 2004/1 I, p. 257 en 258.

121 Uniken Venerna, a.w, p. 94. UNIKEN VENEMA stelt als omschrijving voor: 'rechten die strekken tot beînvloeding of tot correctie van de beleids- of besluitvorming van de uitgevende instelling'. Op deze manier wordt de limitatieve categorie uit art. 15 lid 2 WGE uitgebreid met reeds bestaande rechten - genoemd wordt bijwoorbeld het recht tot aantasting van besluiten ex art. 2:15 - alsmede uitbreiding met nog nieuw te yormen rechten. 
Daarenboven wijst UNIKEN VENEMA terecht op de beperking van de zorgplicht van de aangesloten instelling. Krachten artikel 15 WGE dient zij enkel zorg te dragen voor de mogelijkheid tot uitoefening van het stemrecht. Met UNIKEN VENEMA ben ik van mening dat ook hier een uitbreiding op haar plaats is. ${ }^{122}$ De voorgestelde uitbreiding van inspraakrechten waarvan de aangesloten instelling is uitgesloten dient samen te gaan met een uitgebreide actieve zorgplicht teneinde de inspraakgerechtigden te faciliteren bij het gebruik van deze rechten. In de praktijk hoeft zulks niet veel om het lijf te hebben. De reeds ingeburgerde verklaring ten bate van de stemgerechtigde aandeelhouder kan mijn inziens eenvoudig naar deze situatie worden getransponeerd:

$\mathrm{Nu}$ - het systeem van - de WGE wordt heroverwogen, is een bepaling die voorgaande wijzigingen behelst geen overbodige luxe. In dit kader stel ik woor artikel 23 WGE uit te breiden met een tweede lid:

"Indien de vruchtgebruiker de rechten als genoemd in artikel 11 lid 3 toekomt, is artikel 15 van overeenkomstige toepassing.'

\subsection{Conclusie}

De vestiging van een recht van vruchtgebruik op een aandeel neemt vele vormen aan. Niet in alle gevallen is de goederenrechtelijke en/of de vennootschaps-rechtelijke positie van de vruchtgebruiker eenvoudig weer te geven. De verschillende regelingen hebben niet zonder meer oog voor de in potentie aanwezige vruchtgebruiker. In geval van een aandeel op naam richten de problemen zich op het smeden van de band met de vennootschap. Betekening door de vruchtgebruiker van de notariële akte is, hoewel niet constitutief, wel geraden. Dit probleem wordt ingeval van een beursgenoteerde vennootschap geëcarteerd doordat de erkenning daar wel onderdeel uitmaakt van de eisen voor vestiging.

De diversiteit die zich openbaart bij het aandeel aan toonder brengt verschillende problemen met zich. Meest in het oog lopend is de verandering van het goederenrechtelijk karakter van het aandeel. Het toonderbewijs als roerende zaak is na invoering van de WGE geleidelijk overschaduwd door het recht op naam sui generis. Hoewel fysieke toonderbewijzen nog wel bestaan wordt het gros van de toonderaandelen verhandeld in het systeem van de WGE die een recht op naam van eigen aard creëert. Het object van vruchtgebruik verandert daardoor. Deze laatste conclusie is op haar beurt relevant voor de inhoud van het vruchtgebruik. Immers de aard van het object bepaalt de reikwijdte van de bevoegdheden van de vruchtgebruiker.

Daar waar nog sprake is van een uitgeleverd toonderbewijs doet zich het probleem voor van de legitimerende functie van bezit. Zoals reeds in het goederenrechtelijke deel is aangekaart, is een wetswijziging die een feitelijke machtsverschaffing bij de

$\$ 22$ Uniken Venema, a.w., p. 97. 
levering van een zaak voorschrijft geraden. In het kader van het klassieke toonderstuk is nuancering echter geboden. Met het voorstel de onderhandse akte in dit kader te introduceren heb ik gepoogd dit probleem het hoofd te bieden en tezelfdertijd aansluiting te zoeken bij vergelijkbare bestaande regelíngen. ${ }^{12 x}$

Tot slot heb ik gewezen op het gebrek aan duidelijkheid over de vennootschapsrechtelijke positie van de vruchtgebruiker op een aandeel in de WGE. De voorstellen die UNIKEN VENEMA in dit kader doet, dienen in overweging te worden genomen. Zowel de sterngerechitigde als de (slechts) inspraakgerechtigde vruchtgebruiker verdienen een expliciete regeling in de WGE.

123 Hier past desalniettemin de relativering dat het bestaan van toonderstakken geen larg leven beschoren lijkt. Zo spreekt s bij de behandeling van de artt. 10 en 13 WGE beeldend van. "zuigkraclabepalingen" Hij geeft dararmee gan dat effecten en dus ook (nog) bestaande toonderaandelen door het systeem van de Wos "wotden aangezogen en binnengezogen". Uniken Venema, a. w, p. 213. 


\section{Hoofdstuk 5}

\section{VRUCHTGEBRUIKER-AANDEELHOUDER}

\subsection{Inleiding}

In dit hoofdstuk staat de relatie vruchtgebruiker - aandeelhouder central. De juridische invulling van deze relatie kent zowel goederenrechtelijke als vennootschapsrechtelijke aspecten. Om te beginnen zijn de inhoud van het wruchtgebruik en de bevoegdheden van de vruchtgebruiker rechtstreeks gelieerd aan het rechtsobject dat bezwaard is met het recht van vruchtgebruik. Derhalve is een analyse van de ard van een aandeel in een kapitaalvennootschap vereist voor de bespreking van de rechtspositie van de vruchtgebruiker op dat aandeel. ${ }^{2}$ Immers, het vestigen van het vruchtgebruik houdt in dat bevoegdheden die de rechthebbende voor de vestiging toekwamen nu - op grond van regels van goederenrecht - worden uitgeoefend door de vruchtgebruiker. In het onderhavige hoofdstuk vindt de zojuist bedoelde analyse van een aandeel plaats. In de eerstvolgende paragraaf wordt het rechtskarakter van een aandeel en het aandeelhouderschap in een kapitaalvennootschap kort beschreven. Het rechts-karakter geeft zodoende inzicht in de aard van een aandeel die bepalend is voor de bevoegdheden tot gebruik. Aansluitend wordt in $\$ 5.3$ besproken welke, eventueel van de aard afwijkende, bestemming de aandeelhouder aan zijn wruchtgebruik kan geven. De bestemming van het aandeel is, evenals haar aard, een omstandigheid die meegenomen dient te worden in de beoordeling van de bevoegdheden van de vruchtgebruiker. ${ }^{3}$

Terugkoppelend worden in de daaropvolgende paragraaf de bevoegdheden die de vmchtgebruker op grond van de aard en de bestemming van een aandeel mag verwachten, besproken (\$5.5). Daarbij zal zowel aandacht worden geschonken aan de bevoegdheden op basis van het goederenrecht - waaronder het karakter van de vrucht van een aandeel $(\$ 5.5 .1)$ - alsook aan de mogelijkheden voor uitbreiding van deze bewoegdheden op grond wan het erfrecht. Ten slotte staat \$5.5.4. in het teken van cen tweetal vraagstukken rondom de beschikkingsbevoegde vruchtgebruiker.

1 Hierover 82.4 .

2 Bij gebreke aan regels vam gebraik en verbruik is de aard wan het goed immers bepalend voor genoemde bevoegdheden. Art. 3:207 lid 1. Vergelijk $\$ 2,4,2$.

3 Art. 3212 lid 1 bepaalt dat woor zover de goederen bestemd zijn on te worden wervreendi de vruchtgebruiker tot deze bestemde vervreemding bewoegd is. Vergelik $\$ 2,4.4 .1$. 


\subsection{Het rechtskarakter en de aard van aandeelhouderschap en andeel}

\subsubsection{Inleiding}

De beschrijwing van het rechtskarakter en de aard van een aandeel legt meteen het complexe karakter van een aandeel in een kapitaalvennootschap bloot. In de literatunir wordt wooreerst onderscheid gemaakt tussen het rechtskarakter van het aandeelhoudersehap enerzijds en de rechten uit het aandeelhouderschap voort-vloeiend anderzijds. Het aandeelhouderschap wordt gekwalificeerd als een bijzondere lidmaatschapsverhouding. Deze lidmaatschapsverhouding is de bron van de rechten en plichten van de aandeelhouder. De laatst genoemde rechten kennen op hun beurt weer een duidelijke tweedeling.

In het HANDBOEK NV/BV verwoordt VAN DER GRINTEN de samenhang als volgt:

'Deze lidmaatschapsverhouding wordt als aandeelhouderschap aangeduid. Dit aandeelhouderschap brengt rechten en verplichtingen mede. (...) De aandeelhouder is gehouden tot volstorting van zijn aandeel en de aandeelhouder verkrijgt werbintenisrechtelijke aanspraken - dividend en liquidatieuitkering - tegenover de vennootschap. Het aandeelhouderschap heeft verder effect. De aandeelhouder heeft zeggenschap in de vennootschap; hij heeft vergaderingsrecht en stemrecht.."

VAN SCHILFGAARDE omschrijft de tweedeling in de rechten:

"Het recht van aandeel laat zich ontleden in een aantal onderling samenhangende rechten. Sommige van deze rechten zijn vermogensrechtelijk van aard, andere hebben een ondersteunend karakter. (...) Met deze twee aspecten van het recht van aandeel corresponderen de twee functies die men pleegt te onderscheiden. Enerzijds de beleggingsfunctie, anderzijds de zeggenschapsfunctie. ${ }^{6}$

MAEIJER formuleert krachtig:

"Voor wat betreft de rechten wan de aandeelhouder kan men onderscheiden tussen rechten in het financiële vlak en rechten in het vlak van de zeggenschap. ${ }^{7}$

4 Zite recentelijk. W. Slagter "Ondewemingsrech $2004,1, \mathrm{p}, 425$ en wolgende:

$5 \quad$ Handboek NV/BV (1992), n. 131.

6 Van Schilfgarde/Winter (2003), $\mathrm{nr}, 32$.

7 Asser/Maeijer 2-III (2000), nr. 177. 
Tot besluit de woorden van LOWENSTEYN:

'De definitie van aandeel en aandeelhouderschap begint dus met een verplichting [tot betaling van de nominale waarde; $E C B$ ]. Maar tegenower die verplichting staan rechten. De aandeelhouders hebben stemrecht in de algemene vergadering van aandeelhouders, zij hebben het recht op een gedeelte van de winst alsmede van het liquidatiesaldo in geval van vereffening. Zij hebben nog enige ander bevoegdheden, alle samenhangend met de hiervoor genoemde aanspraken. ${ }^{8}$

Hoewel bovenstaande beschrijvingen en karakteriseringen een evidente eensgezindheid in zich dragen is de onderlinge samenhang alsmede het grotere kader daarmee niet gegeven. In de volgende paragrafen zal ik de twee genoemde aspecten en buin onderlinge samenhang verder bespreken. Daarbij maak ik onderscheid tussen het aandeelhouderschap in de BV en bet aandeelhouderschap in de NV.

\subsubsection{Vermogensaspect}

Het vermogensaspect van een aandeel kent mijns inziens een zekere dualiteit. De literatuur richt zich bij de invulling van het vermogensaspect op de rechten van de aandeelhouder die vermogensrechtelijk van aard zijn. De meest prominente plaats wordt ingenomen door het recht op dividend. ${ }^{9}$ Daarnaast valt te denken aan het recht om te delen in het liquidatiesaldo. ${ }^{10}$ In het kader van dit laatste spreekt het HANDBOEK NV/BV van een "onlosbare schuld van de vennootsehap". De aandeelhouders zijn in beginsel de rechthebbenden op deze vermogensrechten. Deze rechten worden, in tegenstelling tot de zeggensmacht, uitgeoefend jegens de vennootschap. Het vermogensaspect heeft voor de aandeelhouder echter een bredere betekenis. Niet alleen geeft het aandeel recht op voornoemde vermogensrechten, het aandeel zelf wordt ook als vermogensrecht gekwalificeerd. Het aandeel als vermogensbestanddeel heeft gedurende de laatste jaren sterk aan belang gewonnen. Niettegenstaande het ruw ontwaken uit de droom van de technologie-hausse van de jaren negentig en de recente beursschandalen blijven aandelen onverminderd een belangrijke plaats in het vermogen(sbeheer) van natuurlijke en rechtspersonen innemen.

8 Pitllo Lôwensteyn (1994), par. 4.41

9 Art. 2:105 en 2:216.

10 Art. 2:23b lid. 1 .

11 Handboek NW/BV (1992), nr, 161. De solund is onlosbatat, omdat de vennootschap die schuld niest tijdens haar bestaan, maar slechts na haar ontbinding kan inlossen, mits alle vennootschapssehumiden ziju voldaar. 


\subsubsection{Zeggenschapsaspect}

Alle aandeelhouders komt in beginsel het recht van stem toe. ${ }^{12}$ Dit recht kan de aandeelhouder uitoefenen tijdens de algemene vergadering van aandeelhouders, alwaar hif tevens het recht heeft het woord te voeren. ${ }^{3}$ Door middel van het stemrecht neemt de aandeelhouder actief deel in de besluitworming van de vennootschap. Daarenboven beschikt de aandeellhouder over een aantal ondersteunende rechten. Men denke daarbij aan algemene vergaderrechten ${ }^{14}$, het agenderingsrecht ${ }^{15}$ alsmede onder omstandigheden enkele specifieke vennootschapsrechtelijke instrumenten als de rechten uit de uitkoop-en geschillenregeling ${ }^{16}$ en het recht van enquête ${ }^{17}$.

\subsubsection{Het lidmaatschap: onderscheid tussen de BV en de $N V$}

Het aandeelhouderschap wordt zoals vermeld gekwalificeerd als een lidmaatschapsverhouding. Deze bijzondere vennootschapsrechtelijke lidmaat-schapsverhouding houdt voor de aandeelhouder in dat hij met zijn wettelijk stemrecht rechtstreeks betrokken is bij de besluitvorming in de vennootschap. ${ }^{18}$ Daarnaast staat hij gezien zijn vermogensrechtelijke rechten, alsmede zijn plichten, in een relatie tot de vennootschap. ${ }^{19}$ Het lidmaatschap is daarmee de bron van de zojuist besproken vermogensrechtelijke rechten en zeggenschapsrechten. Kenmerkend voor lidmaatschapsverhoudingen in het algemeen is dat er sprake is van gezamenlijke besluitvorming en dat deze in beginsel bij meerderheid geschiedt. ${ }^{20} \mathrm{Het}$ is ook in het lidmaatschapskarakter waar de verschillen tussen de kapitaalvennootschappen hun wortels vinden. Algemeen gesproken is het lidmaatschapskarakter van de BV ar een van beslotenheid. ${ }^{21}$ De leden vormen een min of meer vaste groep, waarbij de gezamenlijke aan-

12. Art $2: 118 / 228$ lid 1 openingszin.

13 Art: $2: 117 / 227$.

14. Zie hierover Asser/Maeijer 2-III (2000), nr. 283.

15 Art. 2:114a.

16 Respectiewelijk art $2: 92 \mathrm{a} 201 \mathrm{a}$ en art. 2336343 . De geschillentegeling is in beginsel echter alleen toegankelijk voor NV's, indien zij een besloten karakter in de zin van art. $2: 335$ lid 2 kennen. Zie $\$ 6.6$.

17 Art. $2: 345$

18 Art. 2:117/227.

19 Van Schilfgaarde/Winter (2003), nr. 1. Vergelijk mijn eerder ingenomen stelling dat vestiging van vruchtgebiruik ten minste inhoudt de cessie van het vermogensirecht 'dividend' jegens de wennootschap $(\$ 4.3,3)$.

20 Vergelijk SLACTER ( $a . w_{,}, p .424$ ) die erop wijst dat in het algemeen verbintenissenrecht de unanimiteil regeert.

21 Hoewel onlangs wijzigingen zijn woorgesteld aangaande de juridische structurur van de BV, betreffen deze wijzigingen met name een vergroting van de flexibiliteit walarmee de BV wordt ingericht. Het intuin pejsonae karakter en het beperkte aantal aandeellhouders blijwen een centrale rol spelen. Vergelijk de MVT (p. 4) bij voorontwerp wijziging Boek 2 BW in verband met de aanpassing van de BV 
deelhouders als een bok op de haverkist zitten. De beslotenheid wordt in wettelijke zin gediend door de restrictie van aandelen op naam ${ }^{22}$ en de voorgeschreven blokkeringsregeling ${ }^{23}$. In deze zin is de karakteristiek van een aandeel op naam een bijkomende factor. Het "benoemen" van de aandeelhouder kan in dit verband gezien worden als een uitdrukking van het intuitu personae karakter.

Daartegenover staat de NV die in beginsel een open karakter kent. De groep aandeelhoudende leden kan sterker variëren en de verhandelbaarheid van het toonderaandeel kent weinig - vennootschapsrechtelijke - grenzen. De voorgaande stellingen kennen tal van nuances, dewelke onder andere in de verschillende soorten aandelen worden gevonden. De kapitaalvennootschap kan bijwoorbeeld zelf de aard wan het aandeel (of het aandeelhouderschap ${ }^{24}$ ) beïnvloeden door aan bepaalde soorten aandelen specifieke kenmerken toe te kennen. Door het emitteren van prioriteitsaandelen creëert zij aandelen die een versterkte positie innemen op het gebied van zeggensmacht. ${ }^{25}$ Daartegenover staat het (gewone) preferente aandeel dat het vermogensrechtelijke aspect van dat aandeel benadrukt. ${ }^{26}$ Deze nuances spelen echter met name een rol bij de karakterisering van een specifieke vennootschap en zijn aandeelhouders, waarbij tevens een rol is weggelegd voor de bestemming die de aandeelhouder zijn aandeel meegeeft. ${ }^{27}$ De ingenomen steilingen zijn daarmee te zien als punt van vertrek voor de uiteindelijke karakterisering van een specifiek aandeel en het bijbehorende aandeelhouderschap.

\subsubsection{Verhouding tussen vermogen en zeggenschap}

De verhouding tussen vermogen en zeggenschap is wellicht het best te illustreren met de ontwikkeling van de Nederlandse corporate governance'-discussie: In 2001 bracht de Sociaal Economische Raad ${ }^{28}$ op verzoek van het kabinet advies uit over het functioneren van de Nederlandse structururregeling. De SER deed zijn werk grondig. Niet alleen werd de structuurregeling tegen het licht gehouden, maar de beoordeling van deze regeling werd in een veel breder kader geplaatst. De SER achtte het in het belang van het advies om het een bredere strekking te geven en:

22 Art. 2:175 lid 1.

23 Art. 2:195.

24 Zo wijst WINTER onder andere op thet feit dat het overgrote deel wan de Nederlandse niat-beursgenoteerde NV's een besloten karakter kent. Van Schilfgaarde/Winter (2003), nr. 10.

25 Asser/Maeiger 2-III (2000), n. 196, alsnede wintgebreider over prioriteitsaandelen en oligarchische regelingen bet proefschrift van CREMGRS. IH.FJ. Cremers; diss. KUN (1971), p. 3 en verder.

26 Asser/Macijer 2-III (2000), nr. 195. De kapitadvennootschap kan een gecombineerd effect sorteren door preferente aandelen uit te geven die door hun grote abntal van inwloed zin op de zeggenschapswerhoudingen in de AVA. De uitgifte van dergelike beschermingsprefs betreft strikt genomen echter geen benadrukking wan het zeggenschapsaspect van het aandeel of het aandeellhouderschap. Inmers, het is het aontal aandelen dat invloed heeft op het totad aan zeggenschap in de AVA.

27 Verder hierover in $\$ 3$ wan dit hoofdstuk.

28 Hierna: de SER. 
'(...) daarin onder meer ook te betrekken de wijze van samenstelling van de raad van commissarissen (RvC), de wenselijkheid van een zekere herijking van de positie van aandeelhouders en certificaathouders [cursief van mij, $E C B]$ en het belang van evenwicht in de bevoegdheden van de algemene vergadering van aandeelhouders (AvA) en de ondernemingsraad (OR), ${ }^{29}$

In zijn advies betoogde de SER dat de andeellhouders en certificaathouders als 'verschaffers van risicodragend kapitaal' een sterkere positie in de kapitaal-vennootschap toekwam. ${ }^{30}$ Daartoe deed hij enkele voorstellen tot uitbreiding van besluiten die specifiek door de AvA dienden te worden genomen. Daarnaast stelde de SER voor de certificaathouder het stemrecht rechtstreeks toe te delen. ${ }^{31}$ De wetgever liet niet lang op zich wachten en meeliftend op de discussie rond corporate governance zag de wijziging van de structuurregeling in 2004 het levenslicht. ${ }^{32}$

Uit het voorgaande kan geconcludeerd worden dat er een (voorzichtige) herintrede en versterking heeft plaatsgevonden van het adagium: wie betaalt, bepaalt. Het verschaffen van het risicodragende kapitaal is onlosmakelijk verbonden met de uitoefening van zeggensmacht over dat kapital.

\subsubsection{Conclusie}

De eigenaar van een aandeel in een kapitaalvennootschap staat in een bijzondere lidmaatschapsverhouding tot deze vennootschap. In het kader van deze lidmaatschapsverhouding is hij rechthebbende op vermogensrechten jegens de vennootschap en bekleedt hij in verband hiermee een zeggenschapspositie in de vennootschap.

Naar de aard van het aandeelhouderschap in een BV komt in beginsel de nadruk meer te liggen op de zeggenschap en de daarmee samenhangende invloed op de besluitworming en het beleid. Naar de aard van het aandeelhouderschap in een NV ligt de nadruk voor de aandeelhouder in beginsel juist op de vermogensrechtelijke aspecten van het aandeelhouderschap. Hierbij kan zowel gedacht worden aan dividend als aan de koerswinst op het aandeel bij vervreemding.

29. Kanterstukken II $2000-2001,25732$, nr. 17, p. 5 .

30 Kanerstukken I/ $2000-2001,25732$, nr. 17, p. 57. Overigens borduurde de SER daarbij doelbewust woort op het rapport Peters (Kamerstukken $/ / 2000-2001,25732$, p. 13).

31 Kamerstukken $/ 2000-2001,25732$, nr. 17, p. 60. De rechtstreekse toekenning wan stemrecht stuitto op wetstechische bezwaren. Zie de publicatie van HAMERs en mijzelf in WPNR 6452 (2001), p. 645-646; alsmede uitgebreider E.C. Bos en JJ.A. Hamers, Stichting \& Yereniging 2001/5, p. 89 en volgende. De uiteindelijke regeling baseerde zich op het systeem van de privatieve volmacht. Meer hierover in $\$ 6.2$.

32 Wet van 9 juli 2004, Srb. 2004, nr. 370 . 


\subsection{De bestemming van een aandeel}

\subsubsection{Bestemming door de aandeelhowder ${ }^{3}$}

De aard en het rechtskarakter van een aandeel in een kapitaalvennootschap zijn objectieve grootheden. Zij bieden een inzicht in de functie van het aandeel en de rechtspositie van zijn rechthebbende. Naast deze objectieve kenmerken is het mogelijk dat de rechthebbende zijn eigen invulling geeft aan zijn gerechtigdheid tot het aandeel. Daarbij is de aandeelhouder tot op zekere hoogte beperkt door de aard en het rechtskarakter, maar hij kan duidelijke accenten leggen binnen deze kaders door een specifieke bestemming aan zijn aandelen toe te kennen. ${ }^{34}$ Het belang van deze toegekende bestemming ligt met name in de bevoegdheden die de vruchtgebruiker toekomen. Is het de bestemming van een aandeel om vervreemd te worden, dan is de bevoegdheid daartoe van de vruchtgebruiker daarmee een (wettelijk) gegeven. ${ }^{35} \mathrm{Hoe}-$ wel BERENSCHOT ten aanzien van de bestemming van effecten precies deze stelling inneemt ${ }^{36}$, denk ik dat zulks zonder verdere nuancering onhoudbaar is. Immers, zojuist is betoogd dat er wezenlijke verschillen zijn in aandelen en aandeelhouderschap. Om te beginnen dient de aard van het aandeelhouderschap in ogenschouw genomen te worden. De beslotenheid van een BV staat in beginsel bijvoorbeeld haaks op een (ruime) vervreemdingsbevoegdheid van de vruchtgebruiker. ${ }^{37}$ Daartegenover staat de aard van het aandeel en aandeelhouderschap in de NV. De openheid en verhandelbaarheid van het aandeel in de NV biedt de vruchtgebruiker, in tegenstelling tot de BV, naar mijn smaak een vermoeden van vervreemdingsbevoegdheid. Het is in dit kader dat ik BERENSCHOT's eerdergenoemde stellingname begrijp. Deze conclusie wordt bovendien - waarschijnlijk onbedoeld - ondersteund door het systeem van de WGE wanneer men zich realiseert dat bij aandelen die in het systeem vallen de deelgerechtigdheid in het verzameldepot object is van vruchtgebruik. Derhalve is het object de verzameling aandelen die door de deelgerechtigdheid worden vertegenwoordigd. De waarde van dit goed wordt beinvloed door de (injactiviteit van de rechthebbende.

Beide voorgaande vermoedens ten aanzien van de BV en de NV dienen echter getoetst te worden aan de bestemming die de aandeelhouder aan het andeel heef

33. Voor de goede orde herinner ik de lezer erasan dat $i k$, in het geval de vruchtgebruiker krachtens erfrecht zijn vruchtgebruik werkrijgtt; aanneem dat de bestemming die de erflater aan het aandeel of de aandelen gaf leidend is voor de beoordeling van de bevoegdheid van de vruchtgebruiker. vergelijk $\$ 2.4 .4$.

34 Zo ook voor wat betreft het vruchtgebruik in het algemeen; Pitlo/Reelhuis-Heisterkamp (2001), nr. 697.

35 Art. 3:212 lid 1. Vergelijk de algemeen goederenrechtelijke bespreking in $\$ 2.4,42$.

36 E.B. Berenschot, WPNR 5730 (1985), p. 175.

37 Daarbij worden het vennootschapsrechtelijke probleem inzake verwreending door de vruchtgebruiker van aandelen in sen BW nog buiten beschouwing gelaten. Zie voor de bespreking van dit specifieke probleem $\$ 5.5 .3$. 
gegeven. Met name bij aandelen in de NV kan men zich voorstellen dat de investering bedoeld is om of een bepaalde vorm van zeggenschap te kunnen uitoefenen of als langdurige investering die op de lange termijn voor rendement moet zorgen. In deze gevallen is een engere invulling van de vervreemdingsbevoegdheid niet ondenkbaar.

\subsubsection{Verandering van bestemming}

In het algemeen goederenrechtelijk deel is reeds aangestipt dat het de vruchtgebruiker niet vrijstaat de bestemming van het object van vruchtgebruik te wijzigen. Artikel 3:208 lid 1 spreekt weliswaar van 'zaken', maar naar mijn mening heeft deze regeling te gelden voor alle goederen. ${ }^{38}$ Aandelen in kapitaalvennootschappen zijn daarbij exemplarisch. ${ }^{39}$ De precieze betekenis van artikel 3:208 laat zich het best voorstellen aan de hand van een voorbeeld.

Wanneer een rechthebbende aandeelhouder wordt in een NV is het open karakter van het aandeelhouderschap daarmee voor de aandeelhouder gegeven. ${ }^{40}$ De eenvoudige verhandelbaarheid van het aandeel, de wisselende samenstelling van de AvA alsmede de nadruk op het vermogensrechtelijke aspect zijn voor de aandeelhouder een relatief objectief uitgangspunt. De aandeelhouder kan echter de betrokken aandelen bestemmen om juist de nadruk te leggen op de in het aandeel-houderschap belichaamde zeggensmacht ${ }^{41}$ Deze toekenning van bestemming heeft naar mijn smaak goederenrechtelijke gevolgen voor de positie van de vruchtgebruiker. Deze laatste is op grond van artikel 3:208 gehouden de aandelen niét te vervreemden, hoewel zulks wellicht uit de aard van het aandeel moge voortvloeien. ${ }^{42}$

Een zelfde redenering heeft minder rigoureuze gevolgen voor de vruchtgebruiker van een aandeel in een BV. Immers, in dat geval wordt de vrijheid van de aandeel-

38 MijnsSEN stelt dat de werking van art. 3:208 beperkt kan blijwen tot zaken daar wijziging van bestemning van iets anders dan een raak 'zich niet laat denken'. Asser/Mijnssen-Van Dam-Van Velten. 3-II (2002), ni 284. Voor het overige lijkt de literatur de discrepantie niet altijd op te merken. Zo stelt K.LEIN dat de vruelitgebruiker (krachtens art. 3:212) de bestemming der goederen mag weranderen. W.M. Kleijn, 'Vruchgebruik: Mon.NBW B-10' (1990), nr. 12. VAN GAALEN laat na de nuance te benoemen en spreekt consequent van een zaak. M.S. van Gaalen, diss. VU(2001), nr. 306-309.

39. Slechts klassieke toonderaandelen kwalificeren als 'zaken'. De owerige aandeelvormen betreffer vermogensrechten.

40. Dit leidt slechts unitzondering bij de expliciet 'besloten' NV Vergelijk noot 24.

41 Precies deze strategie hanteende Greenpeace in 2000 om zeggenschap te krijgen in het beleid wan Shell/Koninklijke Olie NV. Greenpeace kocht op 14 maart 2000 voor 250.000 aandelen Koninklijke Olie on op deze manier Shell ertoe te bewegen te investeren in andere energievormen. ("Greenpeace koopt pakket aandelen Shell" - NRC HANDELSBLAD 14 maart 2000)

42 Dit is enkel anders wanneer de vruchtgebruiker de beschikkingsbewoegdheid ower het goed bij vestiging toebedeeld heeft gekregen. Alsdan is hij tevens gerechtigd de bestemming van de goederen waarover hij mag beschikken te wijzigen. Art. 3:212 lid 2 schakelt art. 3:208 daastoe uit. De verklaring hiervoor is gelegen in het feit dat de bestemmende aandeellhouder door toekenning van het recht van beschilking tevens bestemmingswijzigingen door de vruchtgebruiker mogelijk maakt. 
houder om zijn aandeel te bestemmen veel sterker door de aard van het lidmaatschap beperkt. Hoe graag de betrokken aandeelhouder dat ook zou willen, hij kan aandelen op naam niet bestemmen als een goed dat vervreemd dient te worden. De beslotenheid van het aandeelhouderschap in de BV en daarmee de aard van dit - intuitu personae - aandeelhouderschap verhinderen dat. Het is evenwel denkbaar dat de aandeelhouder zijn lidmaatschap bestemt tot het maximaliseren van de waarde van het aandeel hetgeen zou kunnen blijken uit het structureel reserveren van de winst. De vraag dringt zich op of een dergelijke "bestemming" door de aandeelhouder geoorloofd is wanneer het aandeel bezwaard is met een recht wan vruchtgebruik. Deze vraag dient naar mijn mening echter beantwoord te worden naar vennootschapsrecht. Het is immers de uitoefening van het stemrecht door de aandeelhouder waardoor de vruchtgebruiker de creatie van de burgerlijke vrucht gefrustreerd ziet. ${ }^{43}$

\subsection{Sûr place: aard en bestemming van aandeelhouderschap en aandeel}

'From all this it is clear that there is no simple definition of a share. The various definitions emphasize a complex of characteristics, which are peculiar to it.'

Rechter VAN ZYL in de uitspraak Cooper v Boyes ${ }^{44}$

Hét rechtskarakter en dé bestemming van aandelen en aandeelhouderschap zijn naar mijn mening ongrijpbare grootheden. De diversiteit die in elke van de aspecten tot uiting kan komen, maken een apodictisch totaalbeeld tot een heilige graal. In plaats daarvan is het juist te concluderen dat de verschillende aspecten slechts specerijen zijn die de soep doen smaken en geuren. Meerdere koks buigen zich over het recept en benadrukken naar smaak en behoeven de verschillende specerijen. Het is ten slotte aan de aandeelhouder zelf om ter tafel de Maggi ter hand te nemen. Trekt men de vergelijking door dan is het de soep in deze samenstelling die de vruchtgebruiker mag nuttigen.

\subsection{De bevoegdheden krachtens goederenrecht en erfrecht. Een reprise}

In deze paragraaf zullen de bevoegdheden zoals deze in hoofdstuk 2 reeds zijn besproken nu in het kader van aandelen in kapitaalvennootschappen de revue passeren. Daarbij worden niet alleen de goederenrechtelijke parameters van het vruchtgebruik geëvalueerd, maar ook de zo-even besproken aard en het rechtskarakter van het

43 Zie $\$ 5.5 .1$.

44 "Cooper v Boyes NO' 1994 (4) SA 521 (CPD), p. 535. In $\$ 7.3$ kom ik uitgebreid terug op het verband tussen vruchtgebruik op aandelen en de 'trust' in Zuid-Afrikans reclit. 
aandeel en het aandeelhouderschap. Daarenboven zal bij de bespreking van de positie van de vruchtgebruiker in het nieuwe erfrecht worden betrokken. Zodoende kan een genuanceerd beeld geschetst worden van de verhouding tussen de goederenrechtelijke positie die de vruchtgebruiker toekomt en de specifieke karakteristiek die een aandeel in een kapitaalvennootschap maakt tot wat zij is. Daarbij zullen tevens de verschillende goederenrechtelijke (on)mogelijkheden en vennootschapsrechtelijke eigensoortigheden aan het licht worden gebracht.

\subsubsection{De vrucht van een aandeel}

\subsubsection{Inleiding}

Voor de meeste goederen geldt dat de diversiteit van vruchten verre van groot is. Met name wanneer het zaken betreft worden de grenzen van de vrucht steevast door de natuur gesteld. De potentie van vruchten van een aandeel in een kapitaalvennootschap kent ogenschijnlijk geen grenzen. Het is enkel de fantasie van-de accountant en de jurist van-de vennootschap die dicteert welke voordelen de aandeelhouder toe kunnen komen. De volgende "voordelen' kunnen onder meer aan de aandeelhouder worden uitgekeerd: scrips, stock- of bonusaandelen, contanten, claimbewijzen en optiebewijzen. Allen betreffen - op geld waardeerbare - vermogensrechten en kunnen in potentie als vrucht worden gekwalificeerd. Het mag niet verrassend heten dat bij het kwalificeren van de burgerlijke vrucht ${ }^{45}$ de vruchten van aandelen in een kapitaalvennootschap een centrale plek innemen in de jurisprudentie. De heersende leer ten aanzien van dit vraagstuk stamt uit 1959: het arrest 'Pierlot/Kreemer'. Verder werd de kwalificatie aangescherpt in het arrest 'Staatssecretaris/Erven X': Beide arresten worden aan een analyse onderworpen.

\subsubsection{Jurisprudentie}

\section{'Pierlot/Kreemer' 46}

\section{a) De feiten}

De feiten lagen in 'Pierlot/Kreemer' als volgt. De heer Van Rijen overlijdt en verdeelt in zijn uiterste wil zijn vermogen op de navolgende wijze. Zijn echtgenote Van RijenPierlot ontvangt door middel van een legaat het vruchtgebruik over zijn vermogen. Zijn zussen Kreemer-Van Rijen en De Wal-Van Rijen worden de hoofdgerechtigden. Voorts wordt het vruchtgebruik onder bewind gesteld bij de heer De Wal. Tot de nalatenschap behoort een aantal aandelen op welke derhalve het vruchtgebruik ten behoe-

45 Overigens was de vragg of dividend een burgerlijke danwel een natuurlijke vrucht betrof reeds in lagere rechtspraak geadresseerd. De Rechtbank 's-Grawenhage oordeelde dat 'derhalwe alle vruchten die in geld worden uitgekeerd als burgerligke vruchten behandeld dienen te worden'. Rb "s-Gravenhage 6 jamuari 1949, NJ 1949,626 (Giezen/Fin Lith). 
ve van Van Rijen-Pierlot wordt gevestigd. Deze laatste werd houdster van de dividendbewijzen. De mantel - het eigenlijke toonderaandeel - werd in bewaring gegeven bij een bank ten name van de bewindvoerder en de vruchtgebruikster samen. Op de bezwaarde aandelen werd niet alleen dividend in de vorm van contanten en bonusaandelen uitgekeerd, maar er werden tevens zogenaamde claimbewijzen uitgegeven. Deze claimbewijzen geven recht op inschrijving bij uitgifte van nieuwe aandelen door de vennootschap. De bewindwoerder en hoofdgerechtigden eisten afgitte van deze claimbewijzen, ondat zij van mening waren dat het geen vruchten van de bezwaarde aandelen betroffen en dientengevolge niet aan de vruchtgebruikster toekwamen.

\section{b) De rechtswragg}

De rechtsvraag die de Hoge Raad diende te beamwoorden was welke tutkeringen in geld dan wel toekenningen van op geld waardeerbare voordelen - die an aandeelhouders uit hoofde van hun aandeelhouderschap toekomen 'vruchten' betreffen en welke uitkeringen een "ander voordeel" betreft en derhalve in het wruchtgebruikvermogen vallen. Zoals gezegd verwijst artikel 3:9 hiervoor naar de verkeersopvatting 4 , maar deze was tot dan toe niet eenduidig.

De Hoge Raad antwoordde in de volgende volzin:

'Dat een en ander medebrengt dat een wezenlijk verschil bestaat tussen de uitkeringen die den aandeelhouders toevloeien uit het uit behaalde winsten stammende, (nog) niet ten behoeve wan de bedrifsutitoefening gebonden, en wit dien hoofde wit zijn aard woor "winst" - witkering bestemde deel wan het vermogen, [cursief van mij, $E C B$ ] en de uitkeringen die den aandeelhouders in den een of anderen vorm aanspraken geven op het reeds eerder kachtens bevoegdelijk genomen besluiten ten behoeve van de bedrijfsuitoefening gebonden deel van het vermogen (...).48

Tot deze conclusie komt de Hoge Raad door wit te gaan van het door hem onderken de beginsel van een vrucht; de vrucht mag niet worden verkregen ten koste van de moederzaak, ook niet als deze moederzaak tijdens de daur van het vruchtgebruk "vermeerdert" of "verbetert". Wat betreft deze vermeerdering of verbetering van het stamkapitaal van een aandeel ligt het onderscheidende criterium dus vooral besloten in de woorden "gebonden deel van het vermogen'. "Daaraan koppelt de Hoge Raad

47 Destijds betrof het art. $808 \mathrm{BW}$ (oud). Vergelijk voot het huidige rech $\$ 2.4 .1$ en verder.

48 "Pietlot/Kremuer", p. 1066.

49 De term 'gebonden deel van het vermogen" mag aiet verward worden met dezelfde term die gebruikt wordt voor het kapitabl, de statutaire en wetwelijke reserwes tezamen ex artikell $2: 373$ Iid 4 (Van Schilfgarde/Winter (2003), p.55). De gebondenheid ziet dnkel op de toewizing van de winst door

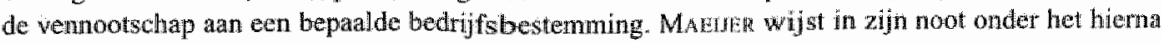
te bespreken arrest 'Staatssecretaris/Erven $X$ ' eveneens op deze mogelijke verwarring. 
enkele "beginselen van vennootschapsrecht". Hij concludeert dat de AvA in beginsel de winst bepaalt en deze bestemt ${ }^{50}$ De hoofdregel is dlat de winst direct als vrucht van het aandee ${ }^{51}$ kan worden uitgekeerd aan de aandeelhouders. De bestemming kan echter ook zijn gelegen in een reserve die later kan worden uitgekeerd - gemakshalve te betitelen alls 'het appeltje voor de dorst'-principe - of in een reserve 'dienstbaar aan een meer blijwende versterking van de positie van de vennootschap'. Deze laatste reserve vormt in dit verband het gebonden deel van het vermogen hetwelk aldus, in tegenstelling tot de voorgaande reserve, niet voor uitkering aan de vruchtgebruiker in aanmerking komt.

Kortom, wanneer een vemnootschap winst heeft gemaakt en deze vervolgens krachtens bevoegdelijk genomen besluit ten behoeve van de bedrijfsuitoefening zal aanwenden, is deze winst als potentieel uitkeerbare vrucht verloren gegaan voor de vruchtgebruiker. Zij gaat als het ware deel uit maken van het aandeel en door haar verbondenheid met de vennootschap diskwalificeert de aldus bestemde winst zich als vrucht. Besluit de vennootschap op een later tijdstip ten laste van deze reserve een uitkering te doen, dan heeft die uitkering betrekking op het eigenlijke vermogensrecht van de aandeelhouder zelf, aldus de Hoge Raad. Uitkeringen uit behaalde winsten die nog niet ten behoeve wan de bedrijfsuitoefening zijn gebonden, worden in dit arrest wél als vruchten wan het aandeel beschouwd, indien door de vennootschap de winst uitdrukkelijk wordt gereserveerd met de bedoeling deze later uit te keren. ${ }^{\text {s2 }}$ Wordt de winst daarentegen bestemd tot financiering van de onderneming dan diskwalificeert zij zich daarmee als vrucht.

In de woorden van de Hoge Raad:

'(...) dat dientengevolge de tot uitkering te brengen 'winst' geenszins behoeft samen te vallen met de winst van het jaar waarop de winstvaststelling betrekking heeft immers aan den enen kant de tot uitkering te brengen 'winst' kan stammen uit winsten van vorige jaren die ten behoeve van latere winstuitkering tijdelijk worden ondergebracht in een zogenaamde 'dividendreserwe" of daarmee vergelijkbare reserve (...), en aan de andere kant [kan gebruik gemaakt zijn, $E C B]$ van de mogelijkheid om een gedeelte van de over een bepaald jaar behaalde winst ten behoeve van de financiering

50 Een beginsel dat ook in het nieuwe BW zijn gelding heeft behouden art 2:105/216. Zie over dit onderwerp meest recentelijk het proefschrift wan BusR. B. Bier, diss. EU (2003), p. 59 en verder.

51. H.P.M. Coebergh, $N Y 36$ (1958), p. 165.

52 De Hoge Raad nam darmee afstand wan het standpunt van het Hof. Het Hof had eerder geoordeeld dat alleen wan een vrucht gesproken kon worden indien het een periodieke nitkering betrof over een bepaald boekjaar. Aldus oordelend sloot het Fof uitkeringen wit welke reserwe dan ook uit als wrucht van het aandeel. Overigens achtte Proe. Gen. LANGEmEBrer het element van periodiciteit 'van bijzonder groot belang' voor het vaststellen wan de vrucht. Zulks werd echter evenmin door de Hoge Rand onderschreven. 
van het bedrijf aan de bestemming tot vroegere of latere "winst'-uitkering te onttrekken. $(\ldots)^{53}$

\section{c) Resumerend}

Zoals uit voorgaande bespreking alsmede uit de citaten van de Hoge Rad moge blijken, ligt naar aanleiding van dit arrest de nadruk op de vraag welke bestemming de winst bij de winstvaststelling krijgt. Het bepalen van de vruchten op een aandeel wordt daarmee een subjectieve aangelegenheid. Het bestuur dat de winstbestemming voorstelt ${ }^{54}$ en de AvA die over dit voorstel beslist bepalen de burgerlijke vrucht van een aandeel.

\section{"Staatssecretaris/ Erven $X^{55}$}

Het arrest 'Pierlot/Kreemer' richtte zich primair op de kwalificatie van (gereserveerde) winst als mogelijke vrucht van een aandeel. In het arrest was duidelijk sprake van een uitkering door de vennootschap. In het arrest 'Staatssecretaris/Erven X' was geen sprake van een uitkering in het kader van de winst van een bepaald boekjaar, noch van uitkering door de vennootschap uit een bepaalde reserve.

\section{a) Defeiten}

De feiten in het arrest lagen enigszins vereenvoudigd ${ }^{56}$ als volgt. Vader en zijn twee zonen beschikken ieder over $32 \%$ van de aandelen in een houdster-maatschappij. De onderneming van vader is ingebracht in een werkmaatschappij. Het aandelenkapitaal in deze werkmaatschappij is onderverdeeld in 49 gewone aandelen $A^{57}$ en 300 aandelen B. Zowel de aandelen A als B hebben een nominale waarde van f1. 1000,- per aandeel. De houdster-maatschappij is gerechtigd tot alle 300 aandelen $Y$ in de werkmaatschappij. Daarnaast zijn 49 aandelen $A$ in de werkmatschappij wederom verdeeld over de vader en zijn zonen. ${ }^{58}$ De houdstermaatschappij sluit met vader en zoons een koopovereenkomst waarmee de houdstermaatschappij al haar aandelen in de werkmaatschappij aanbiedt aan de vader en zijn zoons. Het bedrag waarvoor de aandelen worden aangeboden, is de nominale waarde. De werkelijke waarde wan de

53 "Pierlot/Kreemer", p. 1066.

54 Dit voor zover de wet en statuten nog viliheid laten tot het bestommen van de winst:

55 HR 7 december 1994, NJ 1995, 301 in.nt. Ma (Staatssecreraris/Enven X).

56 Kortheidshalwe heb ik een aantal elementen uit de casus weggelaten. Het betrof onder andere het omzetren wan een $\mathrm{NV}$ in een BV, het oprichten en inbrengen wan de verschillende vemoolschappen, een statutenwijziging alsmede en oudertijke boedelwerdeling wa het overlijclen wan de echngemote van vader. Dit heeft echter geen betrekking op de te behandelen rechtsvraag.

57 Vader beschikte tevens ower 10 prioriteitsaandelen $A$ met en nominale waarde wan f1. 100, . Deze aandelen laat ik echter verder buiten beschouwing.

58 Overigens zijn niet alle aandelen $A$ over de voorgaande drie verdeeld. Een zwager beschikt over éen aandeel $\mathrm{A}$. 
betrokken aandelen ligt hoger. ${ }^{59}$ De uitspraak richt zich in eerste instantie op de vraag wat het belastbaar inkomen van vader is in het licht van voornoemde transactie.

\section{b) De rechisvraag}

De rechtsvraag die voor dit proefschrift van belang is, vloeide voort uit het volgende. Ten tijde van de aankoop van de aandelen was een van de zoons minderjarig. Niet gesteld of gebleken was dat vader niét het wettelijk (ouderlijk) vruchtgenot van diens vermogen had ex artikel 1:2531 ${ }^{60}$. De fiscus stelde dat het voordeel een vrucht betrof en op grond van genoemde bepaling aan de vader zou moeten toekomen. De rechtsvraag die beantwoord diende te worden was of het voordee $l^{61}$ dat door de transactie voor de aandeelhouders wordt bewerkstelligd een vrucht is van het aandeel. De fiscus betoogde voorts dat de meerwaarde niet ontrokken werd aan enige reserve van de werkmaatschappij of de houdster-maatschappij en dat daarom 'Pierlot/Kreemer' niet in de weg staat aan de kwalificatie van vrucht. De Hoge Raad oordeelt echter dat het genoten voordeel wel degelijk onttrokken werd aan het vermogen van de houdstermaatschappij. Het voordeel betreft géén vrucht:

'(..) Het woordeel vindt zijn grond in de op 8 augustus tussen $\mathrm{X}$ en diens beide zonen enerzijds en Beheer [de houdstermaatschappij, $E C B$ ] anderzijds gesloten koopovereenkomst met betrekking tot de aandelen in de werkmaatschappij: De door deze koopovereenkomst bewerkstelligde onttrekking van vermogen aan Beheer door haar aandeelhouders vormt een gedeeltelijke realisering van het eigenlijke vermogensrecht wan de aandeelhouders [cursief van mij, ECB].(...) ${ }^{962}$

De Hoge Raad concludeert dat het voordeel dat de houdstermaatschappij creëert woor haar aandeelhouders door aandelen in de werkmaatschappij tegen nominale waarde te verkopen, geén vrucht is van het aandeel in de houdstermaatschappij. Het betreft volgens de Raad de uitkering van de vermogensvermeerdering van het aandeel in de houdstermaatschappij, ondat de houdstermaatschappij eenvoudig-weg minder waard wordt en dus het stamkapitaal wordt aangetast.

59 In 1983 had de werkmatschappij $90 \%$ van het nomunalle kapitaal aan al haar aandeellouders terngbatald. Als gewolg darvan repesenteren de 300 aandelen slechts $10 \%$ van de oorspronkelijke nominale warde; f1. 30,000,-. De intrinsieke warde van dit pakket werd berekend op f1. $500.000^{2}$." ("Stantssecretaris/lerven $X$, ro. 52 ).

60 Het bewuste artikel is fanilierechtelijk wan aard. Hot stelt dat de ouder die gezag over zin kind uiloxfent het wruchtgenot heeft van diens vermogen. De vaag of een bepald goed een vrucht is kont derhalwe evencens an de orde in het kader van dit artikel.

61 Zijjads de $f$. $470.000_{2}$ - die de aandelen in de werkmattschappij meér ward zijn dan de koopprijs van $\mathrm{f} .30 .000,-$

62 "Staatssecretaris/Erven $X$ " r.o. 3.3. 


\section{c) Resumerend}

De casus van 'Staatssecretaris/Erven $X$ ' is gecompliceerd: De conclusie is dat ook andere voordelen voor aandeelhouders dan dividendutkering de "PierlotKreemer"test dienen te ondergaan. Opvallend is echter wel dat het gebruik van een houdstermaatschappij de vader de das om doet. Immers, het groeien van het stamkapitaal van de houdstermaatschappij is te danken aan - onder andere-de dividenduitkering op de aandelen in de werkmaatschappij. Deze initiele vruchten van de werkmaatschappij worden aldus stamkapitaal van de houdstermaatschappij. Ware zij direct uitgekeerd aan vader en zoons zouden zij wél onder het ouderlijk vruchtgenot van vader zijn gevallen.

\subsubsection{De vrucht van een aandeel nader beschouwd}

\section{De huidige stand van zaken}

De beide besproken arresten geven de huidige stand van zaken weer. Uit "Pierlot' Kreemer' volgt dat wanneer de winst ten behoeve van de bedrijfsüitoefening wordt gereserveerd en aldus 'in het bedrijf wordt teruggestopt' zorgt voor groei van het stamkapitaal. Deze groei komt de vruchtgebruiker niet toe; hij is enkel gerechtigd tot het vruchtgebruik van het aandeel in dit vergrote stamkapitaal. De bepaling van die vrucht is derhalve op grond van het arrest een zuiver vennootschapsrechtelijke aangelegenheid $^{63}$, maar wel een met goederen-rechtelijke consequenties. Op grond van 'Staatssecretaris/Erven $X$ ' moet ook het bevoordelen van aandeelhouders anders dan door uitkering de test van 'Pierlot/Kreemer kunnen doorstaan.

\section{Vruchteloos...}

Hoewel de voorgaande arresten een relatief helder beeld schetsen, is dat beeld vanuit het oogpunt van de vruchtgebruiker niet bevredigend te noemen. Een tweetal prangende problemen blijft namelijk onaangeroerd.

Om te beginnen dient gewezen te worden op een tegenstrijdigheid van artikel 3:9 en het arrest "Pierlot/Kreemer". In hoofdstuk 2 is gewezen op de rol van de verkeersopvatting in de regeling van artikel $3: 9$. Zij werd als uitgangspunt gekozen vanwege haar potentie om met de tijd mee te gaan. ${ }^{64}$ Alsdan kan telkenmale worden aangesloten bij de steeds veranderende praktijk. Deze flexibele eigenschap lijkt in tegenspraak

63 Vanuit vennootschapsrechtelijk perspectief zijn het winstbesluit en goedkeuring wan de jarrekening op deze manier voor de whchigebruker op en aandeel wan levensbetang. Het vennootschapsrechn biedt de vruchtgebruker ook buten het stenrecht de mogelijkheid een rol te spelen in de besluitvorming. Zie $\$ 6.2 .2$ en $\$ 6.2 .3$

64 Vergelijh miju bespreking van de verkeersopwatting van ant. $3: 9$ in 82.4 . 1 . Saillatu detail is dat Proc. Cien. LANGEMELER in zijn conclusie meenmalen zijn beklag doet over het feit dat deze rechtsvaag aan de Hoge $\mathbb{R}$ aad wordt voorgelegd, terwijl het stelsel zich richt "naat de in de maatschappij levende opwathingen'. Hij verwijst daabij naar de meningen van MEurrs en SuYLiNG. 
met feit dat 'Pierlot/Kreemer' stamt uit 1958. De vraag is gerechtvaardigd of het arrest nog steeds spoort met de verkeersopvatting 47 jaar na dato. Daarenboven wil ik er, het arrest 'Radio Holland' indachtig ${ }^{65}$, op wijzen dat bestendige bedingen de verkeersopvatting kunnen gaan vormen. Voorstelbaar is dat notarissen - ook nu al - stelselmatig het vruchtbegrip van 'Pierlot/Kreemer' uitbreiden tot elke uitkering uit welke reserve dan ook. Niets staat erflaters in de weg het vruchtbegrip op deze manier uit te breiden. Wat aanvankelijk begint als een obligatoir recht van de vruchtgebruiker kan op grond wan de ratio van het arrest 'Radio Holland' uitgroeien tot een goederenrechtelijke vricht. Indien de wruchtrechtsvraag niet opnieuw aan de kaak wordt gesteld, verwordt het wachten in de praktijk tot het wachten op Godot.

Het tweede probleem betreft een vraag die steeds met de vruchtrechtsvraag in verband lijkt te worden gebracht. Wanneer het pakket aandelen door het beheer van de vruchtgebruiker in waarde stijgt, komt die meerwaarde dan de vruchtgebruiker toe? Het lijkt onbillijk te veronderstellen dat het kennelijk effectieve vermogensbeheer van de vruchtgebruiker niet beloond wordt anders dan door de groei van zijn vruchtgebruik op het aldus toegenomen stamkapitaal. De vraag kan naar mijn smaak niet beantwoord worden in het kader van de vrucht van een aandeel. Daartoe laten de besproken arresten geen ruimte. De beantwoording van dit vraagstuk hangt naar mijn mening echter nauw samen met de aard van het aandeel en de daaruit afgeleide beschikkingsbevoegdlueid van de vruchtgebruiker. Het is om die reden dat het probleem hierna in het kader van de beschikkingsbevoegde vruchtgebruiker wordt behandeld. ${ }^{60}$

\subsubsection{De bevoegdheid tot gebruik, verbruik en beheer}

In deze paragraaf zullen de regeling van gebruik, verbruik en beheer gekoppeld worden aan het vermogensrecht 'aandeel in een kapitaalvennootschap'. De keuze om de regelingen in deze paragraaf te bundelen is gebaseerd op het onderscheid dat ik wil maken tussen deze wettelijke bevoegdheden en de toegekende bevoegdheden inzake beschikking over het bezwaarde goed. Daarmee is niet gezegd dat de grens tussen de twee gebieden hard is. Het komt mij echter in het kader van de helderheid van de bespreking als juist voor de twee vooralsnog te scheiden. Tevens biedt het de mogelijkheid een conclusie voor wat betreft gebruik, verbruik en beheer te formuleren alvorens over te stappen naar de bespreking van de vervreemdings- en beschikkingsbevoegdheid van de vruchtgebruiker op aandelen.

65 HR 16 maart 1979, NJ 1980; 600 m.nt. BW (Radio Holland). Zie woor de bespreking ervan $\$ 4.1 .3$ vain hoofdstuk $\mathrm{I}$.

66 Zie $\$ 5.3 .6$. 


\subsubsection{Gebruik en verbruik}

Naast het recht op de vruchten vormt het gebruik of verbruik van het goed een van de constitutieve rechten van de vruchtgebruiker. De vraag hoe het bezwaarde goed gebruikt danwel verbruikt dient te wonden wordt bepaald door partijen of bij gebreke aan deze regels, door de aard van het goed. ${ }^{67}$ In het kader van aandelen in een kapitalvennootschap is de bedoelde vraag niet eenvoudig te beantwoorden. Het gebruik van het goed "aandeel" is naar mijn smaak in beginsel een passieve aangelegenheid. De aandeelhouder houdt het aandeel. Uit de aard en het karakter van het wandeel volgt deze, in beginsel passieve, houding. ${ }^{\circ}$ Hoewel partijen kunnen afspreken wat onder gebruik valt, ligt het meer voor de hand de rechten van vervreemding en vertering als grenzen van deze bewegingsvrijheid aan te merken. Onder gebruik wordt niét verstaan het uitbrengen van het recht van stem. Hiervoor bestaan leges speciales - artikel 3:219 en specifiek voor de NV en BV respectievelijk 2:88 en 2:197 - die toepassing van artikel $3: 207$ lid 1 op het recht van stem uitsluiten. Ten slotte kan men in het kader van aandelen tevens niet spreken van verbruik. De Hoge Raad besliste reeds in 1959 dat in geval van toonderaandelen bezwaarlijk gesproken kon worden van vervangbare zaken, hetgeen tot de conclusie leidde dat zij niet voor verbruik in aanmerking kwamen: 69

Mijn conclusie is dat, in geval van vruchtgebruik op aandelen voor het gebruik en verbruik een zeer beperkte actieradius dient te gelden. Een actieve opstelling van de vruchtgebruiker in de lidmaatschapsverhouding of de onderliggende goederenrechtelijke verhouding reikt over de grenzen van het gebruik of verbruik en wordt gesanctioneerd door middel van de leges speciales van beschikken, beheer en uitoefening van stemrecht. De mogelijkheden om de goederenrechtelijke verhoudingen op basis van genoemde bijzondere regels in te kleden pleiten mijns inziens sterk voor terughoudendheid ten aanzien van gebruik en verbruik van aandelen. De complexiteit van het aandeel als bijzondere combinatie van vermogensrecht en zeggenschapsrecht is bijzonder gebaat bij de nuances die aldus kunnen worden aangebracht.

\subsubsection{Beheer}

Het beheer wan het bezwaarde goed vindt zijn regeling in artikel 3:207 lid 2. De vruchtgebruiker is tot alle handelingen bevoegd die tot een goed beheer dienstig

67 Ant. 3.207 lid 1. Vergelijk 84.2 hoofdstuth III.

68 MuNSSEN concludeent dat 'onlichamelijke zaken' in sen gemeenschap niet kunnen worden gebruikt. De deelgenoten kumen slechts het genot crwan hebben. Asser/Mijnssen-De Haan 3-I (2001), nt, 452.

69 HR 16 januari 1959, NJ 1959, 355 (Swrierenga), p. 873. Evenwel wotd in de effectenptaktijk gebiukt gemaakt wan de mogelijkheid tot 'verbruikleen van effecten'. Zie uitgebreider hicrover

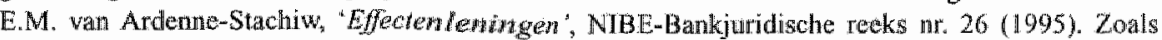
echter vermeld: in hoofdstuk 1 relkt de term effecten amamerkelijk verder dan andelen. Voorts word in hierbij oe lidmatschapswerhouding, die zo kenmerkend is voor het andeelhoudersehap, miskent. Zie hierover $\$ 5.2$. 
zijn. ${ }^{70}$ Evenals bij het gebruik van goederen zijn de woorbeelden van beheer van roerende zaken ruim voorhanden. Daarbij valt te denken aan het in vruchtgebruik gegeven huis dat geschilderd dient te worden en de bomen in de boomgaard die gesnoeid. dienen te worden. Voor wat betreft aandelen in een kapitalvennootschap is de vertaalslag wederom moeilijker te maken. Het beheer wan aandelen kan naar mijn mening hooguit duiden op het bijhouden van de administratie voor deze aandelen. In zekere zin is de positie van de vruchtgebruiker te vergelijken met de bewaarneming van effecten door banken. Aldus ligt mijns inziens in het geval van aandelen de nadruk op de interne functie van de beheersbevoegdheid. ${ }^{\text {II }}$ In de literatuur wordt het beheer evenwel rumer opgevat en in een iets andere context besproken. In het preadvies voor de KNB bespreekt MELLEMA-KRANENBURG de beheersbevoegdheid van de vruchtgebruiker op aandelen in het kader van een toegekende bevoegdheid tot vervreemding en herbelegging. ${ }^{72}$ Hoewel de stap een alleszins logische is, wordt het beeld daardoor vertroebeld. De conclusie moet naar mijn smaak zijn dat, bij afwezigheid van de zo-even genoemde bevoegdheden van vervreemding en herbelegging. het beheer een zeer beperkte reikwijdte biedt aan de vruchtgebruiker. Zojuist noemde $i k$ in dit verband de eenvoudige plicht tot administratie van de aandelen. De beheersbevoegdheid krijgt woor wat betreft aandelen - of wellicht xelfs vermogensrechten in het algemeen - pas inhoud voor de vruchtgebruiker wanneer hem de bevoegdheid tot vervreemding en herbelegging toekomen ${ }^{73}$ Daarbij verdient opmerking dat de bevoegdheden mijns inziens niet steeds toegekende bevoegdheden dienen te betreffen. Niet vergeten mag worden dat de bestemming van het goed, bij afwezigheid van afspraken hierover, de vruchtgebruiker bevoegd kan maken tot vervreemding overeenkomstig deze bestemming. Ook in dit geval is een verantwoord en adequaat beheer in de geest van het goed vruehtgebruikerschap geraden. Deze opvatting wordt naar mijn smaak onderschreven door de uitspraak van de Hoge Raad die ook MeLLEMA-KRANENBURG in dit kader bespreekt. ${ }^{74}$

70 De slotzin van lid 2 vermeldt ten slotte nog dat ten aamzien van alle overige handelingen de vruchtgebruiker en de hoofdgereohtigde slechts tezmen bevoegd zijn.

7 Vergelijk M.S. wan Gaten, diss. VU (2001), nr. 243

72 MHLLEMA-KRAMENURo: "Velal zall in de wruchtgebruikregeling bepald zijn dat de vruchtgebruiker tot vervreemding en herbelegging bevoegd is. Zo zal bij het vruchtgebruik van een effectenportefeuille verveending en herbeleggen tot het beheer van de vruchtgebruiker behoren." T.J. Mellenat-

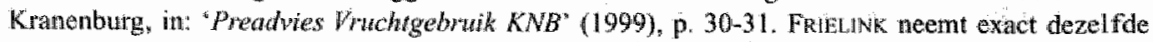
stap bij de bespreking van gebruik en beheer. K. Frielink, TWFS 1992/6, p. I39.

73 Er dient evenwel gewezen tworden op art. 3:210. Het betreft hier een witwerking wan art. 3:207 voor wat betreft in vuchtgebruik gegeven vorderingen. De wetgever maakt de vruchtgebruiker ten anzhen van deze vorderingen pwina finmingsbevoegd. Dit latste leid bij BeRENschor fol de conchisie dat alle beheersbevoegdheden die de vruchtgebruker toekomen privatief werken. E.B. Berenschot, WPNR 5730 (1985), p. 173. WAN GAALEN komt langs cen andere weg tot dezelfde conclusie. Van Gaalen, Giss, nr. 244. 
In het arrest "MeesPierson/Ten Bos"75 verkreeg de langstlevende (Moeder) het vuchtgebruik van het nagelaten vermogen, waarbij de dochters hoofdgerechtigden werden. Moeder verkreeg het wruchtgebruik met volledige beschikingsbevoegdheid. $\mathrm{Zij}$ verleende voor het beheer van haar effectemportefeulle, welke deel uitmaakte van bedoelde nalatenschap, een algemene volmacht aan de heer Ten Cate die op zijn beurt innige banden had met MeesPierson ${ }^{76}$ (de Bank). Ten Cate beheerde het vermogen in samenwerking met de Bank, naar niet veel later blijkt, 'sterk speculatief' en de dochters houden de Bank aansprakelijk voor een verlies - in ëén kalenderjaar! - van meer dan fl. 513.000. De Hoge Raad oordeelde, onder andere, dat het risicovolle vermogensbeheer zoals dat in opdracht van Moeder werd gevaerd niét voor risico van de dochters komt:

'De onderdelen 1 en 2 miskennen dat de vruchtgebraiker jegens de hoofdgerechtigde verplicht is de zorg van een goed huisvader als bedoeld in artikel 831 (oud) BW, respectievelijk de zorg van een goed vruchtgebruiker als bedoeld in artikel 3:207 lid $3 \mathrm{BW}$, in acht te nemen en dat de verplichting, zeker wanneer het gaat on het vermogen van minderjarigen, wordt veronachtzaamd indien het aan het vruchtgebruik onderworpen vermogen - in 's Hofs bewoordingen - 'sterk speculatief' wordt belegd.'

Hij vervolgt:

"Dit is niet anders indien het gaat om het ten behoeve van de langstlevende gevestigde recht van viuchtgebruik van (een gedeelte van) een nalatenschap waarwan de kinderen bloot-eigenaren zijn, waarbij aan de vruchtgebruiker de volledige beschikkingsmacht toekomt ten aanzien van de aan het vruchtgebruik onderworpen goederen. ${ }^{77}$

Vooropgesteld dient te worden dat hier een 'kip-en-het-ej-discussie' gevoerd kan worden. Immers, is het de beheersbevoegdheid of de beschikkingsbevoegdheid die de reikwijdte van het 'goed vruchtgebruikerschap' bepaalt? In deze discussie ben ik geneigd dat laatste te betogen, ondanks een overweldigend aantal schrijvers dat het eerste betoogt. ${ }^{78}$ Unaniem wordt door hen aangenomen dat beheersbevoegdheid van de vruchtgebruiker hem in bepaalde gevallen tot beschikkingsdaden bevoegd maakt, in het bijzonder wanneer het bezwaarde goed een effectenportefeuille betreft. Het

75 HR 9 januari 1998, NJ 1999, $285 \mathrm{~m}$.nt. WMK (MeesPierson/Ten Boss).

76 Strikt gesproken betrof het haar rechts woorgangster Pierson, Heldring \& Pietson.

77 "Meespierson/Ten Bos"; r.0. 3.5. De conclusie van A G DE VRus LevTsich-Kostewse (n: 13) was grotendeels eensluidend.

78 K. Frielink, WPNR 5944 (1990), p 24 alsmede in TWV 1992/6; Mellena -Konenburg, w. w, p. 30; Van Gaalen, diss., Mr. 241; B.E. Reinhartz, PPNR 6455 (2001), p. 739. 
bevreemdt mij ten zeerste dat, hoewel verschillende schrijvers op grond van de beheersbevoegdheid de vruchtgebruiker in éen moeite beschikkingsbevoegd achten over 'een effectenportefeuille", dit object wan wrucht-gebruik aan elke nadere analyse ontsnapt. Zulks terwijl uit de wet en wetsgeschiedenis voldoende blijkt dat het object van vruchtgebruik in veel opzichten de grenzen van het vruchtgebruik bepaalt. Het niet betrekken van de aard van het goed of het niet kwaliliceren van "een effectenportefeuille leidt tot een onzuiver beeld van de bevoegdheden van de vruchtgebruiker en de grenzen van zijn vruchtgebruik. Ik zou derhalve willen betogen dat de reikwijdte van de beschikkingsbevoegdheid van de vruchtgebruiker de beheersfunctie invult. Daarbij dient meegenomen te worden dat de bestemming van het goed een wettelijke vervreemdingsbevoegdheid voor de vuchtgebruiker in het leven kan roepen ${ }^{79}$ De beheersbevoegdheid en de daaraan gekoppelde zorg van een goed vruchtgebruiker - vergelijk hiervoor de bewoordingen van de Hoge Raad in 'MeesPierson/ Ten Bos' - spelen een belangrijke rol bij de uitoefening van genoemde beschikkingsbevoegdheid. ${ }^{80}$ Voor deze benadering is vereist dat een heldere definitie van thet goed is gegeven. Betreft het object én enkel aandeel of een beleggingsportefeuille met verschillende aandelen? De aard en bestemming van de verschillende goederen zullen, zoals besproken in $\$ 5.3$, de doorslag møeten geven.

\subsubsection{Afsluitend}

Het gebruik en beheer van aandelen in kapitaalvennootschappen laat zich niet eenvoudig vangen in bewoordingen en dogmatiek. De diversiteit van aandelen in combinatje met de goederenrechtelijke - en tot op zekere hoogte op de leest van de roerende zaak geschoeide - systematiek van het vruchtgebruik maakt het gevaar voor spraakverwarring reëel. Een zelfstandige beschikkingsbevoegdheid die naar de mening van veel auteurs voortvloeit uit de gebruiksbevoegdheid of de beheersbevoegdheid van de vruchtgebruiker, verdraagt zich naar mijn smaak slecht met het aandeelhouderschap. Derhalve sta ik een strikte interpretatie van gebruik en beheer voor. Bevoegdheden die het aandeelhouderschap regarderen en dus de beschikking en vervreemding beireffen, behoren tot het scala bevoegdheden dat door partijen bij vestiging aan de vruchtgebruiker kan worden toegekend. Daarnaast kan evenwel een vervreemdingsbevoegdheid worden aangenomen wanneer de hoofdgerechtigde zijn

79 De lazer zij erasn herinnend dat hetzij de and hetzij de bestemming beschikkingsbevoegdheden crew bij de vuchtgebrtiker op grond van respectievelijk arit. $3: 207$ lid ll en ant. $3: 212$. Zie mijn bespreking in $\$ 3$ wan dit hoofdstuk. Beknschon likt een zelfde leeswijze voor te staan, met dien verstande dat aif handelingen die worden verricht op grond wan art. $3: 212$ lid 1 altijd dienstig acht tot een goed behert: Berenschot, a.w. p. 173.

80 Hocwel KUIN zich net expliciet witspreekt, nod in zijn monografie noch in zün noot onder het arrest "Meespierson/Ten Bos", over de verhouding beheer - beschikking op de wijze zoals ulteen gezet, voel ik mij gesterkt rloor de nadruk die hij in zijn monografie legt op art $3: 207$ als bron van vetplichringen in plats wan - onder omstandigheden - bron wan rechten tot beschikking. W.M. Klejn, "Vruchrgebrak Mon NBW B-10' 1990), ar. 15. 
aandelen bestemde om verveemd te worden en de vruchtgebruker op grond van artikel 3:212 deze andelen ook mag vervreemden overeenkonstig genoemde bestemming. De plicht tot de zorg wan een goed vruchfgebruiker brengt met zich dat de toegekende of uit de bestemming voortvloeiende beschikkingsbevoegdheden met de vereiste zorgvildigheid worden uitgeoefend. Uit de anshuitende paragrafen zal blijken dat vennootschaps-rechtelijke alsook goederenrechtelijke problemen aanleiding geven deze strikte hantering ten aanzien van aandelen te verkiezen boven de ruimere interpretatie waarin de verstrekkende bevoegdheid tot vervreemding reeds uit de invulling van het beheer voortvloeit.

\subsubsection{De bevoegdheid tot beschikking, venreending en vertering}

\subsubsection{Inleiding}

Het beschikken ${ }^{81}$ door de vruchtgebruiker over goederen uit het vruchtgebruik-vermogen ${ }^{82}$ kent een aantal verschijningsvormen.

De vruchtgebruiker kan:

a) beschikkingsbevoegd zijn op grond van de aard van het goed (artikel $3: 212$ lid 1)

b) beschikkingsbevoegd worden op grond van overeenkomst bij vestiging (artikel 3:212 lid 2)

c) beschikkingsbevoegd worden op grond van afspraak of machtiging (artikel $3: 212$ lid 3 )

d) beschikkings- en verteringsbevoegd worden op grond van overeenkomst bij vestiging (artikel $3: 215$ )

Ten eerste kan de vruchtgebruiker ten aanzien van een goed vervreemdings-bevoegd zijn op grond van artikel 3:212 lid 1. De bevoegdheid tot vervreemding vloeit in dat geval voort uit de bestemming van het goed. Bestemde de hoofdgerechtigde het goed on vervteemd te worden dan komt deze bevoegdlieid ook de vruchtgebruiker toe. Daarnaast kan de vruchtgebruiker structureel de beschikkingsbevoegdheid krijgen over goederen die niet voor vervreemding bestemd zijn op grond van afspraken van die strekking bij vestiging. 8 o meer incidentele wijze kan de vruchtgebruiker beschikkings-bevoegd worden op grond van artikel 3:212 lid 3. Daartoe dient de vruchtgebruiker toestemming van de hoofdgerechtigde te hebben of een machtiging van de kantonrechter te ontvangen na een door de laatste uitgevoerde belangenafwe-

81 Ten owerwloede zij opgemerkt dat onder beschikken vervreenden en bezwaren wordt verstakn.

82 Eerder is aangegeven dat, hoewel de wruchtgebruiker in beginsel ook over zijn recht wan vruchtgebruik, kan beschikken (art. 3:223), deze bevoegdheid in het niewwe erfrecht and de langstlevende vTuchtgebruiker ontanomen wordt (art. 4:23 lid 5). Zie hierover 4.4 van hoolidstuk I.

83 Art. 3:212 lid 2 . 
ging. De erfrechtelijke ${ }^{84}$ wruchtgebruiker kan deze machtiging tevens krijgen wanneer de verzorgings-behoefte dit vereist. ${ }^{85}$ Ten slotte kan de vruchtgebruiker de verstrekkende bevoegdheid worden toegekend tot vervreemding én vertering op grond van artikel 3:215. Ook in dit geval kan de erfrechteliike vruchtgebruiker wegens de verzorgingsbehoefte een beroep doen op een uitgebreidere toegang tot deze bevoegdheden en wel op grond van artikel $4: 23$ lid 2 .

Bij de behandeling van voorgaande bevoegdheden zal het uitoefenen van deze bevoegdheden in het kader van aandelen worden besproken. Aansluitend zal in \$5.5.4. een specifiek probleem worden geadresseerd. Het betreft het probleem van de beschikkingsbevoegde vruchtgebruiker en de beslotenheid van de BV.

\subsubsection{Vervreemden naar bestemming}

De vervreemdingsbevoegdheid van de vruchtgebruiker kan voortvloeien uit de bestemming die de hoofdgerechtigde aan het aandeel geeft. Wanneer de aandeel-houder zijn aandeel bestemt om vervreemd te worden, komt deze bevoegdheid ook de vruchtgebruiker toe. Aangenomen kan worden dat een aandeelhouder in een NV zijn aandelen in beginsel bestemt om te vervreemden. Hier valt met name te denken aan aandelenportefeuilles met aandelen in (beursgenoteerde) kapitaalvennootschappen. De vruchtgebruiker is daarom naar mijn smaak op grond van regels van goederenrecht bevoegd de bezwaarde aandelen te vervreemden overeenkomstig hun bestemming. Een dergelijke beschikkingsbevoegdheid is naar mijn mening zowel voorstelbaar voor de Wge als voor aandelen die (nog) niet in het systeem van de WGE zijn opgenomen. De goederenrechtelijke beleggingsplicht van de vruchtgebruiker ${ }^{86}$ sluit wat mij betreft naadloos aan bij een dergelijke positie van de vruchtgebruiker. Daarenboven kleuren de regels van 'goed vruchtge-bruikerschap' de vermogensbeherende positie van de vruchtgebruiker uitstekend verder in.

\subsubsection{Uitbreiding van de beschikkingsbevoegdheid van de vruchtgebruiker}

De vruchtgebruiker kan op twee manieren beschikkingsbevoegd worden gemaakt ${ }^{87}$ over goederen uit het vruchtgebruikvermogen. Ten eerste kan hem de bevoegdheid bij vestiging structureel worden toegekend door de hoofdgerechtigde. Ten tweede kan hij de bevoegdheid incidenteel ontvangen door toestemming van de hoofdgerechtigde of bij machtiging door de kantonrechter.

84 Bedoeld worden de wormen wan ertrecht die door de wet worden aangeboden; het voorbehouden vruchtgebruik bij wilsrechten (art. 4:19 en 4:21) alsmede het verzorgingsvruchtgebruik (art. 4:30).

85 Art. $4: 23$ lid 1 sub b.

86 Art: $3: 214$.

87 In geval do bestemming van de goederen daartoe aamleiding geeft is de wruchtgebruiker krachtens art. 3:212 lid I beschikkingsbevoegd. 


\section{a) Toekenning bij vestiging}

De hoofdgerechtigde of erflater kan bij de vestiging van het recht van vruchtgebruik de vruchtgebruiker direct beschikkingsbevoegd maken ten aanzien van de onder het vruchtgebruik vallende goederen. Uit de bewoordingen van artikel $3: 212$ lid 2 valt af te leiden ${ }^{88}$ dat het een uitbreiding betreft van de hierboven behandelde bevoegdheid tot vervreemding op grond van de bestemming. Degene die in het kader van wilsrechten goederen opeist van de langstlevende dient zich bewust te zijn van de consequenties die het erfrecht aan een dergelijke bevoegdheidsuitbreiding verbindt. Artikel 4:23 lid 3 schakelt immers de substitutieregel voor wat betreft het door de langstlevende voorbehouden vruchtgebruik uit. ${ }^{89}$ Dit houdt in dat hetgeen ontvangen wordt door de vruchtgebruiker als tegenprestatie voor de goederen waarover beschikt wordt niet tot het vruchtgebruikvermogen gaat behoren. Daarvoor in de plaats treedt een onopeisbare vordering jegens de vruchtgebruiker. ${ }^{90}$ In zekere zin is dit een aantrekkelijke maas in het net voor de vruchtgebruiker. Het stelt hem immers in de gelegenheid het goed los te koppelen van de hoofdgerechtigde. De vruchtgebruiker die aandelen vervreemdt moet de actuele waarde van die aandelen 'ooit' vergoeden aan de hoofdgerechtigde. Vervolgens staat het hem vrij de ontvangen som geld andermaal te beleggen. De meerwarde die hij dusdoende creëert komt hemzelf toe, in tegenstelling tot wanneer er substitutie plaats vindt. ${ }^{\text {1 }}$

\section{b) Toestemming of machtiging}

De wruchtgebruiker kan op grond van artikel 3:212 lid 3 de beschikkingsbevoegdheid over goederen uit het vruchtgebruikvermogen tevens krijgen door middel van toestemming van de hoofdgerechtigde of door middel van machtiging door de kantonrechter $^{92}$ Deze laatste mogelijkheid stelt de vruchtgebruiker in staat autonoom, dat wil zeggen zonder medewerking van de hoofdgerechtigde, de beschikkingsbevoegdheid te ontvangen. De langstlevende die een recht van vruchtgebruik krachtens erfrecht heeft ontvangen kan deze machtiging bovendien verzoeken indien dit noodzakelijk blijkt voor haar verzorgingsbehoefte. ${ }^{93}$ Vermeldenswaardig is dat in dat laatste geval de kantonrechter "nadere regelingen" kan treffen.

88 Art. 3:212 lid. 2 spreekt van "(...) andere dan de in het worige lid genoende goederen."

89 Opmeriking verdient dat deze uitschakeling kan worden voorkomen door met de vruchtgebruiker (het artikel spreekt van echtgenoot) zulks overeen te komen.

90 Ant $4: 23$ lid 3. Deze vordering wordt verwolgens (gedeeltelijk) gelijk gesteld met de vordering die de erfgenamen op de langstlevende krachiens de wettelijke verdeling ontvangen. Voomoemd artikel werklaart art. 4:13 lid 3 en 4 art. $4: 15$ lid. I van overeenkomstige toepassings.

91 De geschetste maas in het net brengt de vruchtgebruiker langs een omweg tot een door mij gewenst resultaat, namelijk het in het vermoggen wan de vruchtgebruker laten vloeien van de meerwaarde door vermogensbeheer. Een structurele oplossing in de relatie vruchtgebruiker - mandeethouder heeft echter mijn woorkeur: Vergelijk hiervoor $\$ 5.3 .6 .2$.

92 Vergelijk 4.4 .2 wan hoofdstuk $I$.

93 Ant $4: 23$ lid 1 sub b. Woor de besprekcing wan de werzorgingsbehoefte zij werwezen natr $\$ 3.5 .3$ 
De bevoegdheid verschilt afgezien van haar 'ad hoc'-karakter miet wezenlijk van de reeds besproken vormen van beschikkingsbevoegdheid met dien verstande dat de rechter gezien de door het artikel vereiste belangenafweging in de gelegenheid wordt gesteld vennootschapsrechtelijke bezwaren mee te nemen in zijn beslissing.

\subsubsection{Vervreemden en verteren}

De meest verregaande bevoegdheid die de vruchtgebruiker kan ontvangen is die van vervreemding en vertering. De bevoegdheid stelt de vruchtgebruiker in de gelegenheid de met het vruchtgebruik bezwaarde goederen te vervreemden en de opbrengst ervan te verteren. Voor de vruchtgebruiker op aandelen brengt het voor wat betreft de goederenrechtelijke invulling niets nieuws. Voor de beschikkings-bevoegdheid kan aangesloten worden bij de opmerkingen in \$5.2.3. Het verteren is het eenvoudigweg opmaken van het geld dat de vruchtgebruiker voor de vervreemde aandelen ontvangt. ${ }^{94}$ Wederom zij er op gewezen dat ook deze bevoegdheid kan worden toegekend aan de langstlevende als vruchtgebruiker wanneer de verzorgingsbehoefte hierom vraagt. ${ }^{95}$

\subsubsection{Afsluitend}

Bij de beoordeling van de goederenrechtelijke bevoegdheden die de vruchtgebruiker van een aandeel toekomen wordt een onderscheid gemaakt tussen enerzijds het gebruik en beheer van de aandelen en anderzijds het beschikken over deze aandelen door de vruchtgebruiker. Ten aanzien van vermogensrechten en aandelen in het bijzonder, is een uitgebreide bevoegdheid tot gebruik, verbruik en beheer hoewel denkbaar, niet voor de hand liggend gegeven het wettelijk kader dat wordt geboden voor het beschikken door de vruchtgebruiker. Het wettelijk kader biedt een systeem waarin de vruchtgebruiker de bevoegdheid tot beschikken niét heeft, tenzij de hoofdgerechtigde of onder omstandigheden de kantonrechter hem deze bevoegdheid expliciet toekent. Slechts ten aanzien van de goederen die de hoofdgerechtigde of erflater bestemde om vervreemd te worden, wordt deze regel omgedraaid en is de vruchtgebruiker bevoegd tot vervreemding overeenkomstig deze bestemming.

\subsubsection{De beschikkingsbevoegde vruchtgebruiker}

\subsubsection{De vruchtgebruiker beschikt over een aandeel in een BV. Collisie}

Een merkwaardig witvloeisel van de uitgebreide beschikkingsbevoegdheid van de vruchtgebruiker manifesteert zich bij het aandeel op naam in een BV. Het is voorstelbaar dat de vruchtgebruiker de beschikkingsbevoegdheid krijgt over een aandeel

94 Onder verteren wordt verstan her beschikken over de opbrengst wan de verweending met het oogmerk dit tos the etgenen. Zie \$2.4.4.4. Daarenboven wijs ik op het bijzondere onderscheid in het erfrecht twsen beschikkingsbevoegdheid enerzids en verveemden en verterem anderijds. Met VAN Mountik meen ik dat de vergoedingsvordering in het laatste geval werminderd moet worden met het bedrag wat de vruchigebruiker aantoonbar heeft verteerd. Zie $\$ 3.4 .3$.

Zie art. $4: 23$ lid 2 . Voor de bespreking zij verwezen naar $\$ 3.5 .4$. 
in een BV. Deze bevoegdheid kan de vruchtgebruiker ontvangen op grond van artikel 3:212 hid 3. ${ }^{96}$ Artikel 4:23 lid lid 1 sub b biedt een extra mogelijkheid voor de erfrechtelijke vruchtgebruiker om de beschikkingsbevoegdheid te ontvangen. Het is met name de voor dit artikel als grond geldende verzorgings-behoefte die de rechter ertoe kan brengen de vruchtgebruiker woornoemde bevoegdheid te verlenen. De aandeelhoudende hoofdgerechtigde zit als gevolg van een dergelijke toekenning in een uitermate lastig parket. Enerzijds wordt de beslotenheid van de BV bedreigd en dient goedkeuring verkregen te worden of dienen de aandelen aangeboden te worden..$^{97}$ Anderzijds moet de aandeelhouder knarsetandend toezien hoe zijn aandeel in de BV wordt vervreemd. Per slot van rekening is hij goederenrechtelijk gezien niet in stat $z i j n$ eigen aandeel te verkrijgen door het te kopen van de vruchtgebruiker. ${ }^{98}$

De aandeelhouder heeft in beginsel zelf in de hand of hij op deze manier tussen wal en schip geraakt. Om te voorkomen dat de vruchtgebruiker de bedoelde beschikkingsbevoegdheid van de kantonrechter ontvangt, kan hij er zorg voor dragen dat de langstlevende voldoende wordt verzorgd. Daarbij valt voor wat betreft bet aandeel bijwoorbeeld al te denken aan het - regelmatig - uitkeren van dividend. Mocht het zover komen dat het verzoek om de machtiging ex artikel 4:23 lid 2 bij de kantonrechter komt te liggen, is deze laatste nog in de gelegenheid om naar eigen inzicht deze Gordiaanse knoop te ontwarren of door te hakken. Artikel 4:23 lid 2 biedt de rechter de mogelijkheid 'nadere regelingen te treffen'.

\subsubsection{De vruchtgebruiker beschikkingsbevoegd over een aandeel in een NV}

Indien de vruchtgebruiker hetzij op grond van de bestemming van het aandeel, hetzij op grond van opgenomen regels bij vestiging, hetzij op grond van incidentele toestemming van de hoofdgerechtigde of machtiging van de rechter, beschikkingsbevoegd is met betrekking tot aandelen in een naamloze vennootschap, brengt dat een tweetal vraagstukken met zich mee.

Ten eerste wordt de goederenrechtelijke substitutie naar heersende leer slechts aangenomen voor zaken die door bezitsverschaffing kunnen worden geleverd. Beschikt de vruchtgebruiker over goederen of geld uit het vruchtgebruikvermogen en ontvangt hij toonderaandelen dan is de hoofdgerechtigde degene die de aandelen verkrijgt; zij het dat ze op grond van dezelfde substitutieregel bezwaard zijn met het recht van vruchtgebruilk. ${ }^{99}$ Beschikt de vruchtgebruiker echter over een recht op

96 De overige manieren om de vruchtgebruiker beschikkingsbevoegd te maken, berusten op een overeenkomst met de hoofdgerechtigde. Het is onwarschijnilijk aan te nemen dat de hoofdgerechtigde - of indien vnuchtgebruik wordt gevestigd ten gevolge van cen witerste will-de erflater de beslotenheid wan de $B V$ op deze manier ondergraaft

97 Art. 2:195.

98 De analogie met het beroemde relaas van Baron Von Munchausen die zich aan zijn eigen haar uit het moeras trok, kont onwillekeurig bij me op.

99 Hier zij er reeds op gewezen dat de substitutieregel wordt uitgeschakeld wanneer de bewoegdheidsuitbreiding een erfrechtelijke achtergrond kent. Vergelijk art, 4:23 lid 3 als ook de bespreking in hierna. 
naam of over de deelgerechtigdheid in de zin wan de WGE dan staat de heersende leer ten aanzien van substitutie en de directe verkrijging in de weg aan verkrijging van aandelen door de hoofdgerechtigde. De vruchtgebruiker heeft slechts een doorleveringsplicht: ${ }^{100}$

Het tweede aandachtspunt is niet zozeer een vraagstuk als wel een bijzonderheid van het aandeel als vermogensbestanddeel. Wanneer de vruchtgebruiker vervreemdingsbevoegd is, staat het hen vrij de aandelen te wervreemden en daarvoor nieuwe aandelen of andere effecten in de plaats te verkrijgen. In het arrest 'MeesPierson/Ten Bos' was 'sprake van een dergelijke bewoegde vruchtgebruikster die op grond van deze beschikkingsbevoegdheid aandelen vervreemdde en verkreeg. Verantwoorde vervreemding en verkrijging kumnen ertoe leiden dat het pakket aandelen in waarde stijgt: Deze waardestijging komt de vruchtgebruiker op grond van regels van vruchtgebruik niet toe. ${ }^{101}$ Het is met name geen vrucht van de betrokken aandelen. ${ }^{102} \mathrm{Nu}$ de vruchtgebruiker geen aanspraak kan maken op de door hem gerealiseerde meerwaarde, maar wél aansprakelijk kan worden gehouden voor eventueel verlies op grond van strijdigheid met 'goed vruchtgebruikerschap', stelt zich de vraag of hier een betere balans in te vinden is.

De ratio van het wruchtgebruik in het (versterf)erfrecht is het verzorgen van de langstlevende. ${ }^{103}$ De verzorging wordt bewerkstelligd door een ruime invulling van het vruchtgebruik op goederen uit de nalatenschap. Op de tweede plaats komt het beschermen van het vermogen van de hoofdgerechtigden tegen risico's van waardevermindering. Dat deze balans in beginsel in het voordeel van de langstlevende uitvalt is onder meer af te leiden uit de uitgebreidere toegang tot beschikken en verteren die de vruchtgebruiker wordt geboden door middel van het erfrecht. Het uitschakelen van de substitutie is tevens een regeling die de vruchtgebruiker grotere vrijheid biedt.

In het geval de vruchtgebruiker de beschikkingsbevoegdheid over goederen uit het vruchtgebruikvermogen op grond van artikel $4: 23$ lid 1 sub b toekomt, resteert op basis van lid 3 van genoemd artikel voor de hoofdgerechtigde in beginsel slechts een onopeisbare vordering:

'In afwijking van de eerste zin van artikel 213 lid 1 van Boek 3 en van artikel 215 lid 1 van Boek 3 verkrijgt de hoofdgerechtigde, tenzij hij met de echtgenoot anders overeenkomt, op het tijdstip van vervreemding een vor-

1002 ie $\$ 2.6 .3$

101 Opgemerkt zij dat zulks niet geldt voor het voorbehouden vinchtgebruik in het kader van de wilsreehten. Het uitschakelen wan de substitutieregel stelt de vruchtgebruiker in dat gevall wel in staat zich de gecreeërde meerwaarde wan het antndeel toe te eigenen. De vruelatgebruiker is slechts gehouden de waarde bij verkoop aan de hoofdgerechtigde te vergoeden. Zie \$5.3.3.L.

102 Vergelijk het onderwerp van de wrucht van een aandeel $(\$ 5.5 .1)$

103 Vergelijk $\$ 3,3,3$. 
dering op de echtgenoot ter grootte wan de waarde die het goed op dat tijdstip had.

Wellicht onbedoeld biedt de regeling het hoofd aan beide hierboven geschetste problemen. Enerzijds wordt de substitutie uitgeschakeld en anderzijds wordt de wruchtgebruiker door beschikking over het goed wolledig gerechtigd tot hetgeen hij ontvangt. Wat overblijft is een obligatoire rechtsverhouding. De vinchtgebruiker is volledig rechthebbende geworden op de aandelen onder de last van de onopeisbare vordering van artikel 4:23 lid 3. Op deze manier wordt het vrachtgebruik losgekoppeld van de onderliggende goederen. De vruchtgebruiker, nu onbezwaard rechthebbende, kan gegenereerde winst op vervreemde aandelen tot de zijne rekenen. De waarde van de vergoedingsvordering is constant en kan bijvoorbeeld worden vermeerderd met een rente en inflatie incorporerend percentage. ${ }^{104}$

De ironie wil dat de geschetste regeling op deze manier sterk doet denken aan het vruchtgebruik van vóór 1992. In hoofdstuk 2 is reeds kort gewezen op het feit dat het vruchtgebruk onder het oude BW twee gedaantes kende. Enerzijds het eigenlijke vruchtgebruik en anderzijds het oneigenlijke vruchtgebruik.

De laatste vorm betrof vruchtgebruik van "vervangbare" en "verbruikbare" zaken. Het oneigenlijke element verwees naar het feit dat de betrokken zaak in eigendom overgedragen werd aan de wtuchtgebruiker. Op de vruchtgebruiker rustte vervolgende de verplichting na afloop van het vruchtgebruik $^{105}$ dezelfde soort zaken te retoumeren. ${ }^{106}$

Hoewel de wetgever voor het samenvoegen wan de beide vruchtgebruikvormen onder het oude BW tot een vruchtgebrukvorm in het nieuwe BW werd geprezen ${ }^{107}$, ontglipte de rechtspraktijk tezelfdertijd het praktische instrument van het oneigenlijke vruchtgebruik. Immers, de oneigenlijke vruchtgebruiker kon voor eigen rekening en risico het vruchtgebruikvermogen gebruiken. Zolang hij de in vruchtgebruik ontvangen soort zaken aan het eind kon retoumeren stond het hem vrij ower deze zaken te beschikken. Het arrest "Swierenga'108 vormt in dat opzicht een praktijkvoorbeeld.

104 Hierbij kan leentjebun gespeeld worden met de fiscale regeling inzake inkomen wit wetmogen. Zie uitgeloreider $87.2 .3-$ noot 25 .

105 Onder het oude recht sprak men dus ondanks de overdracht vay eigendom toch van wruchtgebruik en wuchtgebruiker. Vanwege de heldetheid wan bespreken zall ik deze benamingen in deze patjigraf aanliouden.

106 Art. $804 \mathrm{BW}$ (oud). Zie woor een uitgebrejde bespreking van de - mofivering vain - de aftsehaffing van dit onderscheid M.S. wan Galen, diss. $W U(2001)$, nr. 029 en verdet:

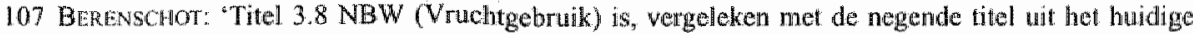
Derde Boek inzake dezelfde materie, een voorbeeld bij titstek yan wat wen wergever, die moderniserend wil optreden, vermag te bereiken. EB. Berenschot, WPNR 5730 (1985), p. 170.

108 HR 16 januari 1959, N/ 1959,355 (Swienenga). 
Een erflater had aan zijn broer Swierenga het vruchtgebruik van zijn gehele nalatenschap gelegateerd, waaronder 10 toonderaandelen à fl. 500 . De vruchtgebruiker had, tegen de wil wan de hoofdgerechtigden in, een aantal toonderaandelen verkocht voor f1. $25.000,-$. De Hoge Raad achtte de vruchtgebruiker aansprakelijk voor de door de hoofdgerechtigden geleden schade. De schade, zo oordeelde de Hoge Raad, is geheel onafhankelijk van de opbrengst van de betrokken verkoop. De schade zag op het vervangen van de betrokken aandelen. De aandelen die destijds voor fl. 25.000 werden verkocht; konden nu voor het luttele bedrag van fl. 4.608 ,- worden teruggekocht. De erfgenamen van de vruchtgebruiker boden de hoofdgerechtigden onzelfzuchtig aan de aandelen aldus te vervangen: Zodoende plukte de vruchtgebruiker, en niet de hoofdgerechtigden, in figuurlijke zin de vruchten van de verkoop en koersstijging. Immers, de vruchtgebruiker behield het verschil in waarde. Proc.-Gen. LANGEMEIER concludeerde onder andere dat de bedoeling van partijen een rol kan spelen voor de kwalificatie van de vervangbaarheid van in vruchtgebruik gegeven zaken. De redenering van LANGEMEIJER zou ik willen transponeren en ik zou menen dat de bestemming van de hoofdgerechtigde goederen uit het vruchtgebruikvermogen tot vervangbaar kan bestempelen, hetgeen naar oud BW de vruchtgebruiker enkel verplichtte de goederen of de waarde van de goederen ten tijde van de vestiging van vruchtgebruik te restitueren: Een dergelijke conclusie sluit mijns inziens naadloos aan bij de uitwerking van de zo-even besproken uitschakeling van de substitutieregel krachtens artikel 4:23.

\subsection{Conclusie}

Dit hoofdstuk concentreerde zich op de relatie vruchtgebruiker - aandeelhouder. Het toepassen van de bevoegdheden die de vruchtgebruiker op grond van titel 8 van Boek 3 BW toekomen op de complexe verhouding die in het aandeel in de kapitaalvennootschap is gelegen, is geen eenvoudige opgave gebleken. Het rechtskarakter van cen aandeel kan per aandeel - en zelfs per vennootschap - verschillen, hetgeen door de aard van het vruchtgebruikregime rechtstreeks consequenties heeft voor de vruchtgebruiker. Een goed begrip van het rechtskarakter van het bezwaarde aandeel alsook de bestemming die de insteller van het vruchtgebruik daaraan gaf, vormen het uitgangspunt voor de rechtspositie van de vruchtgebruiker.

Wanneer, zoals ik in dit hoofdstuk heb gedaan, een duidelijk onderscheid wordt gemaakt tussen de bevoegdheden van gebruik en verbruik enerzijds en de diverse vormen van beschikkingsbevoegdheid anderzijds, is de rechtspositie van zowel de vruchtgebruiker als de bezwaarde aandeelhouder het meest gediend bij de nadruk op het normenkader van de laatste categorie. De regelingen betreffende de vervreemdingsbevoegdheid (artikel 3:212 lid 1) alsmede de beschikkingsbevoegd-heden ${ }^{109}$

109 Art. 3:212 lid 2 en 3, art. 3:215. 
bieden een normenkader dat op regelend niveau voor de vruchtgebruiker de juiste uitgangspunten herbergt en daarnaast de insteller van het vruchtgebruik voldoende gelegenheid biedt dat kader aan te scherpen.

De zienswijze ten aanzien van de vrucht van een aandeel heeft sinds de uitspraak van 'Pierlot/Kreemer' geen wijziging van betekenis gekend. De vrucht van een aandeel wordt, naast wettelijke en statutaire eisen, door de besluitvorming in de AvA gecreëerd. De creatie draagt derhalve een subjectief element dat naar mijn smaak, in de relatie vruchtgebruiker - aandeellhouder, naar regels van vennootschapsrecht dient te worden gereguleerd. " 0 op grond van het uitblijven van uitspraken in het kader van vruchten van aandelen is er tevens geen reden aan te nemen dat de Hoge Raad zijn in 1958 opgetekende visie hierover aanstonds zal wijzigen. Dit laat echter onverlet dat de ruimte voor groei van het vruchtgebruikbegrip ontegenzeggelijik aanwezig is. Met name het feit dat artikel 3:9 de verkeersopvatting als uitgangspunt neemt voor de bepaling van de goederenrechtelijke wrucht maakt dit mogelijk. In hoofdstuk 2 heb ik reeds benadrukt dat dit uitgangspunt ertoe leidt dat hetgeen de betrokken praktijk tot wrucht bestempelt, kan uitgroeien tot de goederenrechtelijke vrucht. Daarenboven geven andere aspecten van vruchtgebruik op een aandeel de vruchtgebruiker de mogelijkheid de potentiële vermogensgroei van het bezwaarde goed te benutten. In dit kader sloot ik de vorige paragraaf af met de uitwerking van de uitgeschakelde substitutiebepaling. Verrassenderwijs creëert deze bepaling van erfrecht een rechtsverhouding die in hoge mate vergelijkbaar is met ons oude 'oneigenlijke' vruchtgebruik. De mogelijkheid om vruchtgebruik op aandelen aldus als verzorgingsinstrument in te zetten biedt mijns ziens perspectieven voor de erfrechtelijke vruchtgebruiker.

$110 \operatorname{In} \$ 6.2 .3$. 
$+\quad-\quad \operatorname{ses}^{2}$

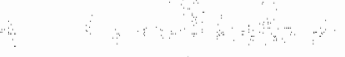




\section{Hoofdstuk 6}

\section{VRUCHTGEBRUTKER - VENNOOTSCHAP}

\subsection{Inleiding}

In het vorige hoofdstuk lag de nadruk op de verhouding tussen de vruchtgebruiker en de aandeelhouder. De vruchtgebruiker kan echter ook in een directe rechtsverhouding tot de vennootschap komen te staan. De totstandkoming en de vorm van deze rechtsverhouding worden in het onderhavige hoofdstuk geanalyseerd: Bovendien kan en zal de vruchtgebruiker op aandelen in veel gevallen in aanraking komen met een aantal bijzondere vennootschapsrechtelijke situaties. De positie die hij in deze situaties inneemt is in sommige gevallen volstrekt helder en in andere weer niet. Met name zijn directe betrokkenheid bij het lot van de aandeelhouder maakt dat de vruchtgebruiker op de hoogte moet zijn wan zijn rechtspositie en die van zijn aandeelhouder. Bij de bespreking van de verschillende rechtsverhoudingen is het bovendien essentieel onderscheid te maken tussen rechtsmiddelen van en tegen de aandeelhouder die de vruchtgebruiker raken enerzijds en de rechtsmiddelen die zich specifiek richten tot de vruchtgebruiker anderzijds. Het moge duidelijk zijn dat de eerste categorie groter is dan de tweede. Niettemin is het onderscheid wan belang ondat bij de rechtsmiddelen gericht tegen de aandeelhouder de belangen van de vruchtgebruiker meer dan eens niet worden meegenomen bij de beoordeling van deze rechtsmiddelen.

Alvorens de verschillende vennootschapsrechtelijke situaties waarin de vruchtgebruiker verzeild kan raken te bespreken, gaat de aandacht allereerst wit naar de rechtsverhoudingen die met de betrokken vennootschap kunnen worden vormgegeven. Dit proces kent in wezen twee gedaanten. Ten eerste kan de aandeelhouder bij de vestiging het stemrecht op het bezwaarde aandeel an de vruchtgebruiker overdragen. Een tot dan toe door de aandeelhouder gebruikt element van de lidmaatschapswerhouding; wordt als gevolg van de overdracht an de viuchtgebruiker ter beschikking gesteld. Bespreking van deze constructie vindt plaats in $\$ 6.2 .1$. Ten tweede heeft de wetgever de vruchtgebruiker (voorwaardelijk) gelijkgesteld met de bewilligd certificaathouder, hetgeen voor de eerste betekent dat hij dezelfde rechten als de certificaathouder tot zijn beschikking heeft $(\$ 6.2 .2)$. Naar zal blijken betekent deze gelijkstelling dat de vruchtgebruiker tevens deel uitmaakt van de zogeheten "redelijkheids- en billijkheidskring" van artikel 2:8 (\$6.2.3). De betrokkenheid bij deze kring wersterkt de rechtspositie wan de vruchtgebruiker.

De bijzondere vennootschapsrechtelijke situaties zullen in afzonderlijke paragrafen worden geadresseerd. Achtereemvolgens zullen worden behandeld: de geschillenregeling, de uitkoopregeling en de juridische fusie en splitsing. 


\subsection{Bevoegdheden krachtens vennootschapsrecht}

\subsubsection{Inleiding: het sternecht}

Van de bijzondere lidmaatschapsrechten die aan het aandeelhouderschap werbonden zijn, neemt het recht van stem de voornaamste plaats in. Het stemrecht biedt de aandeelhouder de mogelijkheid direct deel te nemen in de besluitvorming van de vennootschap." Wanneer een aandeel in een kapitaalvennootschap in vruchtgebruik wordt gegeven is de hoofdregel dat het recht van stem bij de aandeelhouder blijft. ${ }^{2}$ De keuze van de wetgever om het stemrecht bij de aandeelhouder te laten berusten, motiveerde hij aldus:

'(..) de vestiging van vruchtgebruik [komt] in het algemeen voor bij erfrechtelijke overgangen, waarbij zij waak dient ter woldoening aan een dringende morele verplichting, en zij moet daarom steeds mogelijk zijn, dan geldt dit met name voor wat betreft de economische waarde en niet zozeer voor wat betreft de daaraan verbonden zeggensehap. ${ }^{[3]}$ (...) Het stemrecht, waarbij de beslotenheid in het geding komt, kan daarom in beginsel bij de eigenaar blijven. ${ }^{4}$

De wetgever heeft darartoe een belangenafweging gemaakt. Hoewel hij erkende dat de vruchtgebruiker baat heeft bij het stemrecht, beperkt het belang van de vruchtgebruiker zich slechts tot de instandhouding wan het vermogen en de uitkering van dividend. De wetgever concludeert terecht dat de belangen van de aandeelhouder talrijker zijn en die van de vruchtgebruiker daarom overstijgen. ${ }^{5}$

Echter, de wetgever heeft niet willen uitsluiten dat de béperkt gerechtigde overeenkomt met de aandeelhouder dat de eerste het stemrecht kan uitoefenen in de algemene vergadering van aandeelhouders, mits het vennootschappelijk belang hiermee niet wordt geschaad. ${ }^{6}$ Daartoe heeft hij een specifieke regeling in de wet opgenomen. De overdracht van stemrecht zal afzonderlijk worden besproken voor aandelen in de BV en de NV daar het besloten karakter van de eerste eigensoortige problemen met zich meebrengt en mitsdien voldoende aanleiding geeft voor separate behandeling.

1 Vergelijk $\$ 4.2$

2 Art. 2:88/197 lid 2.

3 Helas miste de wetgever destijds dat het juist de stemgerechtigden zijn die het dividend - en daarmee de economische waarde voor de vruchtgebruiker - bepalen. Bij de introductie van het netrwe ertrecht repareerde de wetgever (deels) zijn eerdere inschattingsfout door in geval wan een voorbehouden vruchtgebraik ex art. $4: 19$ of $4: 21$ de wruchtgebruiker het stemrecht toe te kennen. Zie $\$ 6.2 .1 .3$.

4 Kamerstukken I/ $1973-1974,12897$, p. 4-5.

5 Zie nitgebreider K.III Visser, disx. RUL (2004), par. 16.

6 Kamersukken II 1973-1974, 12897 , p. 4-5. 


\subsubsection{Stemurecht van de vruchtgebruiker en de beslotenheid van de BV}

Ten aanzien van de vestiging wan een recht wan vruchtgebruik op een aandeel is reeds gebleken dat de blokkeringsregeling in beginsel niet van toepassing is Artikel 2:195 blokkeert de overdracht van aandelen en ziet niet op de vestiging van beperkte rechten op andelen. ${ }^{8}$ De beslotenheid kan echter in gevaar komen indien de vruchtgebruiker en aandeelhouder afspreken dat het stemrecht aan de vruchtgebruiker wordt overgedragen. Een dergelijke afspraak betekent een afwijking van de hoofdregeling in het kader van het stemrecht. In dat geval biedt een lex specialis van artikel $2: 195$, verwat in artikel 2:197 lid 3, uitkomst. De regeling van lid 3 is te zien als een variant op de blokkeringsregeling voor wat betreft de vruchtgebruiker en kent in feite twee smaken. Het eerste deel van lid 3 luidt als volgt:

'3. In afwijking van het voorgaande lid komt het stemrecht toe aan de vruchtgebruiker, indien zulks bij de vestiging van het wnuchtgebruik is bepaald en de wruchtgebruiker een persoon is, aan wie de aandelen overeenkomstig artikel 195 lid I van dit Boek vrijelijk kunnen worden overgedragen [cursief van $\mathrm{mij}, E C B](\ldots)$.'

In het geciteerde lezen wij allereerst dat de vruchtgebruiker het stemrecht kan ontvangen wanneer dit bij de vestiging van het vruchtgebruik is bepaald én de persoon van de vruchtgebruiker behoort tot de vrije kring van artikel 2:195 lid 1. Aangezien eerder gebleken is dat het nieuwe erfrecht een belangrijke leverancier zal zijn van de te vestigen vruchtgebruikvormen zal de persoon van de vruchtgebruiker in veel gevallen in de wettelijke vrije kring vallen. ${ }^{9}$ Op grond van het erfrecht is dit immers veelal de echtgenoot of geregistreerd partner van de aandeelhouder die als langstlevende het vruchtgebruik verkrijgt. Daarenboven is het aannemelijk dat de (vruchtgebruik)legatarissen eveneens familieleden zijn. Op grond van artikel 2:197 lid 3 eerste zin, kan aldus het stemrecht worden overgedragen aan een persoon binnen de vrije kring door eenvoudigweg de stemoverdracht op te nemen bij de vestiging. MAEuER stelt dat de statuten van de BV derhalve geen afbreuk kumnen doen aan deze stemrechtowerdracht. ${ }^{10}$ Zijn stelling behoeft nuancering in dier voege dat de statuten wél de vrije kring kunnen beperken en zelfs in zijn geheel wit kunnen shiten."

$7 \quad$ Zie 4.4 .3 .4

8. Vor de goede orde zij hier nog gewezen op de erfrechtelijke blokkade. Ook deze slatutaire blokkade kan geen afbreuk doen aan de vestigng whin een recht van vruchtgebruik (krachtens erfechl). Zij speelt echter wel een rol bij de - voorafgande - vererving van de aandelen in kwestie. Zie woot een bespreking van deze problematick $\$ 3.7$.

9 Tot de wettelijke wrije kring van de andeelhouder behonen - ex art. 2:195 aerste lid - diens exhtgem

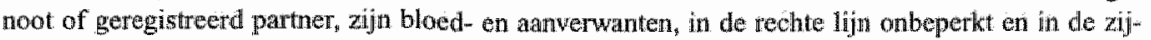
lijn in de tweede graad, cen medeaandewhouder en de vennootschap.

10 Asser/Maeijer 2-III (2000), nr. 223

11 Art $2: 195$ tid 1 bevat de voorwarde '(..) voor zover de statuten deze bevoegdheid llot overdracht

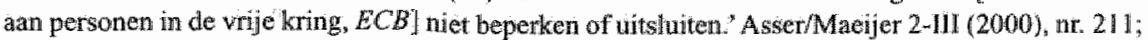
C.A. Schwarz, diss. RUL (1986), p: 6. 
Het uitsluiten van de vrije kring heeft tot gevolg dat de vruchtgebruiker is aangewezen op het tweede deel van artikel 2:195 lid 3:

'Indien de vruchtgebruiker niet zulk een persoon is, komt hem het stemrecht uitsluitend toe, indien dit bij vestiging van het vruchtgebruik is bepaald en de statuten dit niet verbieden, mits zowel deze bepaling als - bij overdracht van het vruchtgebruik - de overgang van het stemrecht is goedgekeurcl door het vennootschapsorgaan dat bij de statuten is angewezen om goedkeuring te verlenen tot een voorgenomen overdracht van aandelen, dan wel - bij het ontbreken van zodanige aanwijzing - door de algemene vergadering van aandeelhouders.'

Behoort de persoon van de vruchtgebruiker niet tot de vrije kring of is de vrije kring door de BV statutair uitgesloten ${ }^{12}$ dan schrijft lid 3 van artikel 2:197 voer dat de overdracht van stemrecht enkel effect kan sorteren wanneer de overdracht niet door de statuten onmogelijk wordt gemaakt ${ }^{13}$ en de overdracht goedgekeurd wordt door het statutair daartoe aangewezen orgaan. Voorzien de statuten niet in een orgaan dat tot die goedkeuring bevoegd is, dan neemt volgens lid 3 de algemene vergadering van aandeelhouders het besluit tot goedkeuring over de voorgenomen stemoverdracht.

Niet altijd is duidelijk of de statuten een goedkeurend orgaan aanwijzen in de zin van artikel 2:197 lid 3. Wanneer de vennootschap bijwoorbeeld heeft gekozen voor een gecombineerde blokkeringsregeling ${ }^{14}$ is zelden zonneklaar of in een dergelijk goedkeurend orgaan is voorzien. NOLET bespreekt dit probleem en kiest voor een strikte benadering. ${ }^{15}$ Zo oordeelt hij dat schriftelijke toestemming van de individuele aandeelhouders geen goedkeuring ex artikel 2:197 lid 3 vormt. ${ }^{16}$ Bij een gecombineerde regeling kan tevens worden gekozen voor een systeem waarbij een vennoot-

12 Aangezien her uitsluiten van de vrije kring in beginsel enkel ziet op de blokkering van aandelen, kan nair mijn smaak niet worden aangenomen dat het uitsluiten van de vrije kring een statutair verbod op overdracht van het stenorecht aan de vruchtgebruiker (ex art. 2:197 lid 3) inhoudt. Noch kan de enkele verwijzing inhouden dat alleen de wettelijke wrije kring bedoeld wordt. Aangenomen moet worden dat de statutaire vrije kring nmatgevend is voor toepassing van art. 2:197 lid 3.

13. De bepaling van de NV (art. $2: 88$ lid 3 ) kent deze mogelikheid tot statutaire uitsluiting eveneens. In dit geval wolgt het uit de zin 'Van het vorige kan in de statuten worden afgeweken'. Oorspronkelijk strekte latstgenoemde vrijheid tot afwijking zich uit over beide zimen van art. 2.88 lid 3 (Kamersituken I/ $1973-1974,12897$, ars. 1-2, p. 2). Later werd deze vrijheid teruggebracht tot de geblokkeerde aandelen (Kanierstukken II 1973-1974, 12 897, nr. 4, p. 10\%.

14 De statuten van een BV mogen een dergelijke combinatie bewatten. Zie Asser/Maeijer 2-Inl (2000), nr. 211 en in het bijzonder HR 31 december $\$ 993, N J 1994,436 \mathrm{~m}$.nt. Ma (Verenigde Bootlieden).

$15 \mathrm{JV}$. Nolet, WPNR $5352(1976)$, p. $367-368$.

16 Een dergelijke conchsie volgt overigens ook al nit het feit dat individuele aandeelhoudersverklaringen als goedkeuring, de Wijsmuller-formulering indachtig, geen 'vrucht van onderling overleg' vormen. (HR 15 juli 1968, N/1969, 101 m.nt. GJS (Hijsmuller). 
schapsorgaan om goedkeuring wordt verzocht om aanbieding te vermijden. In een dergelijk geval is NoLer van mening dat dit vennootschaps-orgaan niet beschouwd kan worden als het goedkeuringsorgaan voor de stemoverdracht, ondat het strikt genomen niet goedkeuring van een aandelenoverdxacht betreft maar dispensatie van de aanbiedingsregeling. ${ }^{17}$ In beide gevalien concludeert hij dat dientengevolge de AvA het aangewezen orgaan is om over de voorgestelde stemoverdracht te beslissen. De strikte benadering van NOLET verdient bijval. De wetgever heeft duidelijk het goedkeurende orgaan in een blokkeringsregeling op het oog gehad. Zulks strookt met de gedachte van het waarborgen van de beslotenlaeid. Een perifere toestemming of goedkeuring kan derhalve niet één op één gelijkgesteld worden met de benodigde goedkeuring. In dit geval kan slechts de AvA als geheel de vruchtgebruiker de sleutel tot de beslotenheid bieden.

\subsubsection{Stemrecht van de vruchtgebruiker en de NV}

De regeling ten aanzien van het overdragen van het stemrecht aan de vruchtgebruiker is voor de NV vrijwel identiek aan die van de BV. Ook hier dient de beoogde stemoverdracht bij vestiging door partijen te worden bepaald en dient de persoon van de vruchtgebruiker tot de kring te behoren aan wie aandelen vrijelijk kunnen worden overgedragen. ${ }^{18}$ Behoort de betrokken persoon niet tot de vrije kring, dan geeft de wet dezelfde regeling als bij de BV ${ }^{19}$ Met name wanneer het aandelen op naam betreft met een daarop van toepassing zijnde blokkeringsregeling geldt het voor de BV geschrevene mutatis mutandis ook voor de NV ${ }^{20}$ In het geval van de NV is echter nog een zin aan het artikel toegevoegd. De bepaling ten aanzien van de niet vrijelijk overdraagbare aandelen wordt gevolgd door:

'Van het bepaalde in de vorige zin kan in de statuten worden afgeweken.'

17 IV. Wollet, a.w; p. 368.

18 Aldus art 2:88 lid 3. VISSER bespreekt wim har proefschrift een stelling wan MoLENAAR uit diens

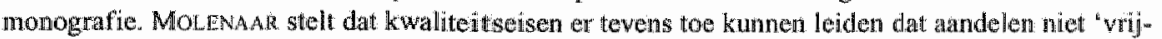

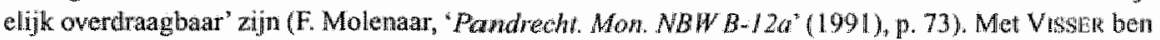
ik van mening dat de door MOL ENAAk gekozen weg de regel van - in dit geval - ait. 2:88 lid 3 geen recht doet. De betrokken NV kan het probleem senvoudig op statutaine wijwe ondervangen. Wisser, diss. par $20-21$.

19 Vergelijk de aangehaalde wettekst op de vorige pagina.

20 De lezer zij erop gewezen dat bijvoorbedld prioriteitsandelen in een NV op nan gesteld zullen zijn daar op deze manier de bijzondere zeggensmacht van het arandeel wordi bewatki. Vergelijk. 84.4 . De statuten yan Koninklijke Olie WV - art. 14 lid 2 - bepalen expliciet dat de vruchtgebruiker het stemrecht op een prioriteitsandeel niat kan ontwangen. Versatel, ASM International, Heijmans en Nutreco hebben een blokkeringsregeling opgenomen ten anzien van het stemrecht op eem bepaglde soort andelem. Zic Bijlage A an B. 
Dit houdt in dat de statuten de wijze waarop het stemrecht wordt overgedragen aan personen buiten de vrije kring kunnen wijzigen en zelfs uitsluiten. ${ }^{21}$

Een NV zal haar aandelenkapitaal echter doorgaans (merendeels) in de vorm van aandelen aan toonder uitgeven. Deze aandelen zijn naar hun aard vrij overdraagbaar. ${ }^{22}$ Dientengevolge kan de aandeellhouder vrijelijk bepalen dat bij de vestiging van het recht van vruchtgebruik het stemrecht wordt overgedragen aan de vruchtgebruiker. Ontvangt de vnuchtgebruiker het stemrecht op aandelen die in het systeem van de WGE zijn opgenomen, wijs ik nogmaals op de door mij gesignaleerde lacune. De wetgever heeft nagelaten een regeling op te nemen inzake de stemgerechtigde vruchtgebruiker van onder de WGE vallende aandelen. De wetswijziging die, zo ik eerder voorstelde ${ }^{23}$, de rechtspositie van stemgerechtigde vruchtgebruiker verheldert is bepaald geen overbodige luxe.

\subsubsection{Uitzondering op de hoofdregel. Vruchtgebruik bij wilsrechten}

Bij de invoering van de wilsrechten heeft de wetgever ervoor gekozen om in het kader van het erfrecht een uitzondering op de hoofdregel van artikel 2:88 en 2:197 lid 2 op te nemen. Ingeval van een voorbehouden vruchtgebruik ten behoeve van de langstlevende bij uitoefening van een wilsrecht ${ }^{24}$, behoudt de vruchtgebruiker het recht van stem op het aandeel. ${ }^{25}$ Er kan in dit kader gesproken worden van "behouden" aangezien de betreffende vruchtgebruiker vóór vestiging van het vruchtgebruik de eigenaar van het aandeel was. Het betreft hier de langstlevende die zich op grond van artikel 4:19 of 4:21 het recht van vruchtgebruik kan voorbehouden. ${ }^{26}$ Aldus wordt op grond van artikel 2:88 en 2:197 lid 3 bewerkstelligd dat het stemrecht op het aandeel eveneens wordt voorbehouden. De (vrijwillige) zeggenschapsbeslotenheid komt in begin-

21 De wet maakt ten aanzien van de personen buiten de vrije kring afwijking nitdrukkelijk mogelijk. Zulks geldt echter niet woor de personen binnen deze kring. Het betreft hier een regel wan dwingend recht (art. 2:25). De statuten van de ING Groep NV bepalen dat een recht van vruchtgebruik weliswaar kan worden gevestigd op een aandeel maar dat het stemrecht, in strijd art. 288 lid 3 , wiet kan worden overgedragen (art. 11 lid 2 van de statuten), De bepaling is tevens in strijd met het voorbehouden recht wan stem zoals dat hierna zall worden besproken. Daarbij dient opgemerkt te worden dat de statuten van recenter datum zijn dan beide regelingen. Vergeefs wordt in de literatuur gezocht natar het antwoord op de viaag wat het rechtsgevolg is wan deze strijdigheid. Aangenomen mag wor den dat de ING Groep NV een wruchtgebruiker die blijkens de overeenkomst van vestiging het stemrecht heeft ontwangen niet als stemgerechtigde zal erkennen. De vruchtgebruiker kan strikt genomen alls belanghebbende echter wel de rechtbank om ontbinding ex art: 221 lid 1 sub b ('statuten vol. doen niet aan de eis der wet") verzoeken. De ontbindingsmaatregel zelf komt mij zonder meer draconisch woor, maar het verzoek kan als pressiemiddel worden ingezet om statutenwijziging af te dwingen. Hel verlenen wan te "terme de grâce' (B.C.M. Waajer, diss. KUN (1993), p. 96) in lid 2 door de rechter, biedt de vennootschap de mogelijkheid tot reparatie.

23 Vergelijk \$5.5.5 van hoofdstuk IV.

24 Voor de bespreking van deze vorm van vruchtgebruik zij verwezen naar \$3.3.2.

25 Art. 2:88/197 lid 3 slotzin. Wet van 1 jantari 2003, Stb. 2002, 429.

26 Zie de bespreking in $\$ 3.3 .2 .3$ 
sel niet in gevaar. Zowel de overgang op de langstlevende als de daaropvolgende overdracht aan een der (stief-) kinderen kunnen door blokkeringsregelingen worden ondervangen. ${ }^{27}$ Daar de langstlevende als eigenaar van het aandeel immiddels is toegetreden tot de besloten kriing, concludeert de wetgever terecht dat het behouden van het stemrecht in het kader van het voorbehouden vruchtgebruik dan ook geen beslotenheidproblemen veroorzaakt. 28

In tegenstelling tot het woorbehouden vruchtgebruik vindt bij de vestiging van het verzorgingsvruchtgebruik ex artikel 4:30 géén stemverschuiving richting vruchtgebruiker plaats. De wetgever vond een dergelijke regeling minder voor de hand liggen. Niettemin plaatste hij een belangrijke kanttekening bij dit besluit. De wetgever stelde dat de uitoefening van het stemrecht door de hoofdgerechtigden geen afbreuk mag doen aan het vruchtgebruik van de vruchtgebruiker. ${ }^{29}$ Deze kanttekening is voor de verzorgingsvruchtgebruiker uitermate belangrijk nu zij naar mijn smaak goede kaarten in handen gedrukt krijgt om haar belang door de andeelhouder vertegenwoordigd te zien. In het bijzonder wanneer het gaat om het winstbesluit kan op grond van voorgaand citaat worden verdedigd dat de hoofdgerechtigde gehouden is vóór uitkering van de winst in de vorm van dividend te stemmen.

\subsubsection{Geen goedkeuring: volmacht}

Wanneer de vruchtgebruiker zijn poging tot verkrijging van het stemrecht ziet stranden door het uitblijven van de vereiste goedkeuring dient de vraag zich aan of partijen zich bij deze uitkomst neer dienen te leggen. Is er wellicht een andere oplossing voor de door hen gewenste rechtsverhouding ten aanzien van het sternrecht? Onderling zijn de wruchtgebruiker en de aandeelhouder immers overeengekomen dat de eerste gerechtigd zal zijn het stemrecht op het aandeel uit te oefenen. De werking van deze verbintenis ontstijgt door het uitblijven van de goedkeuring niet het obligatoire karakter. Men kan zich de vraag stellen of een dergelijke verbintenis niet aldus moet worden geïnterpreteerd dat, indien de directe vennootschapsrechtelijke overdracht niet voltooid wordt, er sprake is van een volmacht tot uitoefening van stemrecht door de vruchtgebruiker: Een aandeel-houder kan tenslotte, voor wat betreft uitoefening van zijn stemrecint, een schriftelijk gevolmachtigde aanwijzen. ${ }^{30}$ De nogelijkheid bestaat zelfs de volmacht onherroepelijk en doorlopend te maken." De bevoegdheid tot het stemmen door een gevolmachtigde kan door de betrokken vennootschap statutair worden beperkt. ${ }^{32}$ Indien een vennootschap van deze statutaire

27 Mits then aanzien van de owergang naar de langstlevende eer erfrechtelijke blokkade is opgeworpen. Zie de bespreking in $\$ 4$ van hoofdstuk irl.

28 Konnerstukken II 1999-2000, 27245 , nu. 3, p. 4 .

29 Kamersinken II 1999-2000, 27245 , nr. 3, p. 4.

30 Art. 2:117/227 lid 1 openingszin.

31 Art. $3: 74$.

32 Art. 2:117/227 lid 1 wweede zin. 
beperking gebruik maakt, rijst de vraag of het instrument van de volmacht in woornoemd gewal kan worden ingezet.

De meningen hierover zijn verdeeld. MAEUER meent dat de verlening van een algemene en onherroepelijke volmacht aan een vruchtgebruiker die het stemrecht niet heeft (kunnen) ontvangen een nietige rechtshandeling is; vanwege strijd met artikel 3:40, ${ }^{33}$ MaEIJer is van mening dat de zojuist bedoelde eonstructie feitelijk leidt tot materiêle vervreemding van het recht wan stem en derhalve niet door de wettelijke beugel kan. VAN SOLINGE gaat in zijn bijdrage in de bundel "Vertegen-woordiging en tussenpersonen' uitgebreil in op deze kwestie en komt tot een geheel andere conclusie. Volgens hem miskent MAEUER dat de volmacht niet privatief werkt en dientengevolge fundamenteel verschilt van een stemoverdracht. De bevoegdheid tot volmachtwerlening wordt, zo meent hij, niet geraakt door het uitblijven van goedkeuring voor de stemoverdracht ${ }^{34}$ noch door een statutair verbod van de stemoverdracht. ${ }^{35}$ De bevoegdheid tot volmachtverlening staat los van de overdracht van stem. Het feit dat de statuten de volmachtverlening als separaat subject kunnen beperken en uitsluiten onderschrijft zijn conclusie. Naar mijn smaak verdient de visie van VAN SOLANGE bijval. De mate van beslotenheid en de toegang tot het stemrecht wordt beheerst door de inkleding der statuten. Wanneer de overgang van het stemrecht onmogelijk is gemaakt of statutaire obstakels niet kunnen worden overwonnen, is de volmachtverlening een reëel alternatief. De goederenrechtelijke rechtsverhouding die de aandeelhouder met zijn vruchtgebruiker heeft maakt dat alternatief des te aantrekkelijker. De vennootschap die coûte que coûte zeggenschapsrechten aan de beperkt gerechtigde wil onthouden en daardoor een sterke beslotenheid wens te creëren, zal ook de mogelijkheid van volmachtverlening door de aandeelhouder statutair dienen te beperken.

\subsubsection{Overdracht of overgang van vruchtgebruik en het stemrecht}

Onder bepaalde omstandigheden is thet voorstelbaar dat een vruchtgebruiker zijn vruchtgebruik op de aandelen kan overdragen. ${ }^{36}$ Wanneer deze vruchtgebruiker over het stemrecht beschikt rijst de vraag of het stemrecht mee over wordt gedragen. De wet kent geen regeling ten aanzien van de consequenties voor het stemrecht bij overdracht van het vruchtgebruik. Met VISSER valt aan te nemen dat een dergelijke overdracht van vruchtgebruik inclusief het sternrecht slechts dan geldig is wanneer de statuten dat niet verbieden. ${ }^{37}$ De stemoverdracht vindt alsdan plaats volgens de hierbo-

33 Asser/Maejer 2-IJ] (2000), nr. 280; zo ook eerder JM.M. Maejjer, in: 'Problemen rondom de. Atgemene Vergadering (1994), p. 74.

34 Van Solinge, $a$ : $w$, p. 134.

35 Van Solinge; $a$. w. p. 136 en 140.

36 De vruchtgebruiker is in beginsel gerechtigd tot een dergelijke owerdracht krachtens art. $3: 223 \mathrm{BW}$. De vormen wan wruchtgebruik die doon het nieuwe erfrecht in het leven worden geroepen zijn echter uitgezonderd van deze regel. Art. 4:23 lid 5 ontneemt de langstlevende het recht het wruchtgebruik over te dragen of te bezwaren.

Visser, diss., par. 40. 
ven beschreven blokkeringstegeling in het kader van stemoverdracht bij vruchtgebruik.

\subsubsection{Conclusie}

De aandeellhouder is in beginsel vrij over zijn stemrecht te disponeren. $\mathrm{Bij}$ do vestiging wan een recht van vruchtgebruik kan hij ervoor kiezen het stemrecht aan de vruchtgebruiker ower te dragen. Deze stemoverdracht aan de vruclitgebruiker kan echter door de vennootschap op verschillende manieren worden geblokkeerd. Zowel op grond van statuten als door weigering van de goedkeuring kan de toegang tot het stemrecht aan de vruchtgebruiker worden ontzegd. De toekenning aan de vruchtgebruiker die het vruchtgebruik voorbehoudt in het kader van een wilsrecht vormt de uitzondering op deze regeling. Wanneer de pas naar stemrechtowerdracht is afgesneden, blijft een constructic door middel van een volmacht evenwel denkbaar, mits daar in de statuten geen beperkingen over zijn opgenomen.

\subsubsection{Lidmaatschapsrechten. De gellikstelling met de bewilligd certificaat honder}

'Het is redelijk hem daartoe dezelfde rechten toe te kennen als aan houders van certificaten die met medewerking der vennootschap zijn uitgegeven., 38

\subsubsection{Inleiding}

Met deze eenvoudige zinsnede uit de Menorie van Toelichting bij de invoering van de regels omtrent het vruchtgebruik op aandelen werd de rechtspositie van de vruchtgebruiker in vennootschapsrechtelijke zin aanzienlijk versterkt. De wetgever achtte het redelijk de vruchtgebruiker als regel van dwingend recht dezelfde rechten toe te kennen als de bewilligd certificaathouder. De regeling is in zoverre bijzonder van aard dat de wetgever de vruchtgebruiker hier rechtstreeks een positie toekent binnen de vennootschap. In tegenstelling tot de overdracht van het stemrecht van de aandeelhouder betreft het hier dus een erkenning van een eigen rechtspositie. Op verschillende plekken is de gelijkschakeling met de bewilligde certificathouder reeds aangestipt: In de onderhavige paragraaf wordt de toe-keming van deze rechton nader besproken.

\subsubsection{Rechten van de certificathouder}

Krachtens artikel 2:88 en 2:197 lid 4 ontvangt de vruchtgebruiker met stemrecht dezelfde rechten als waarover de houder van met medewerking van de vennootschap uitgegeven certificaten wan aandelen in de betrokken vennootschap kan beschikken. Met VISSER neem ik aan dat ook de rechten van de houder van certificaten die zónder de medewerking van de vennootschap zijn uitgegeven aan de beperkt gerechtig-

Kamerstukken IJ $1973-1974,12897$, nt. 3, p. 5. 
de toekomen ${ }^{39}$ Elke certificaathouder, ongeacht of de certificaten met de medewerking van de vennootschap zijn uitgegeven, heeft een aantal vennootschapsrechtelijke rechten. Naast het recht op inzage in bepaalde stukken ${ }^{40}$ is het meest voorname recht uit deze categorie het recht van enquête ex artikel 2:346."1

In aanvulling op de rechten die elke certificaathouder toekomen, kan de vruchtgebruiker ook toegang krijgen tot de rechten wan - zoals de wet het uitdrukt - "houders wan met medewerking ener vennootschap uitgegeven certificaten'. De houders van detgelijke certificaten worden in de literatuur aangeduid als 'bewilligde' certificaathouders. Bij de beantwoording van de vraag óf er sprake is van bewilliging kent de literatuur twee benaderingen: de feitelijke benadering - met als belangrijkste vertegenwoordiger SCHWARZ ${ }^{42}$ - en de rechtshandeling gerichte benadering - met als belangrijkste vertegenwoordiger VAN DEN INGH ${ }^{43}$. De feitelijke benadering van SCHWARZ houdt in dat bij de minste feitelijke betrokkenheid van de vennootschap de litigieuze medewerking een feit is. VAN DEN INGH verlangt in zijn rechtshandeling gerichte benadering een duidelijk waarneembare rechtshandeling strekkende tot het verlenen van medlewerking van de vennootschap. Hoewel de discussie omtrent deze kwestie nog geen einduitslag heeft gevonden, lijkt de benadering van VAN DEN INGH voorallsnog de beste kaarten te hebben. ${ }^{44} \mathrm{Kan}$ in een bepaald gevall worden aangenomen dat de vennootschap medewerking heeft verleend aan de certificering, dan heeft de betrokken houder van de certificaten de beschikking over een aantal vennootschapsrechtelijke rechten. Aanvankelijk betroffen de rechten van de bewilligd certificaathouder met name vergaderrechten ${ }^{45}$ Sinds de wijziging van de structuurregeling $^{46}$ is daar echter drastisch verandering in gekomen. Niet alleen kan de bewilligd certificaathouder onder bepaalde voorwaarden onderwerpen op de agenda van de AvA plaatsen ${ }^{47}$, daarenboven kan hij van de aandeelhouder ${ }^{48}$ een volmacht verlangen

39 Visser, diss, par. $5-$ noot 17 in fine.

40 Art. 2:24 lid 4 (boeken en bescheiden na ontbinding) en art. 2396 lid 8 (inzage en afschrift beperkte balans indien de vennootschap geen winstoogmerk theeft).

41 In \$6.3.2 wordt gewezen op de mogelijkheid wan de vruchtgebruiker on dit rechtsinstrument te gebruiken bij het afdwingen wan een redellijk dividend(beleid).

42 C.A. Schwar, ThWs $1992 / 1$; 1 . 6 en verder.

43 FJP. van den Ingh, WPNR 6478 (2002), p. 191-192 alsook FJ.P. van den Ingh; Stiching, Verenging d. Venthootschap $2000 / 5$, p. 182 en wolgende.

44 Laatstelijk hebben PORTENGEN en GroENLAND uitgebreid aandacht besteed aan de discussie. Zij scharen zich na hun analyse aan de zijde van VAN DEN INOH. I.C.P. Groenland en H.J. Portengern. WPNR 6559 (2003), p. 947 en verder.

45 Asser/Maeijer 2-1II (2000), ni. 409. Meer uitputtende lijsten treft men aan in de proefschniften van VAN DEN INGH en VAsstiR, respectievelijk p. 245-246 en par. 5 - nout 17.

46 Wet van 9 juli $2004,5 i b .2004$, nr. 370 .

47 Art. $2: 14$ a/224a lid 1 jo lid 4 . Opvallend is dat in dit gevall, in tegenstelling tot de stemrechtbepaling van art $2: 88 / 197$, de vruchtgebruiker niet expliciet is uitgesloten.

48 Bij certificering van atandelen worden de aandelen veelal gehouden door een stichting; de stichting Administratickantoor (stichting $\mathrm{AK}$ ). Op de rechtsverhoudingen in geval van certificering en de vergelijking met het vruchtgebruik op atandelen wordt in $\$ 2$ van het volgende hoofdstuk uitgebreid. ingegaan. 
on in de AvA zijn stem uit te brengen. De vruchtgebruiker en pandhouder zijn echter expliciet uitgesloten van dit recht op een volmacht. ${ }^{49}$

Betwijfeld moet echter worden of het bewilligingsvraagstuk van invloed is op de positie van de vruchtgebruiker. De wet stelt immers dat de groep personen uir artikel 2:88 en $2: 197$ lid 4 'de rechten hebbew van bewilligde certificathouders" 50 Hieruit concludeer ik, en ik word in mijn conclusie niet weersproken door wetsgeschiedenis, literatuur of logica, dat ongeacht of de vennootschap haar medewerking verleent of niet de vruchtgebruiker deze rechten toekomt.

\subsubsection{Gelijkschakeling op grond van artikel $2: 88$ en $2: 197$}

De toegang voor de vruchtgebruiker tot de rechten van de bewilligd certificathouder wordt geregeld door lid 4 van artikel 2:88 en 2:197. Zowel de aandeelhouder die zijn stemrecht heeft overgedragen aan de vruchtgebruiker als de vruchtgebruiker die het stemrecht bij vestiging heeft ontvangen knijgen onwoorwaardelijk de rechten wan de bewilligd certificaathouder toebedeeld." Met VISSER zou ik echter willen aannemen dat in het geval van de aandeelhouder zonder stemrecht niet gesproken kan worden van nieuwe rechten. Naar mijn smaak draagt de aandeethouder slechts het stemrecht over en verliest hij niet tevens zijn andere rechten zodat de toekenning in artikel 2:88 en 2:197 soelaas moet bieden. De aandeelhouder behoudt deze rechten na overdracht van het stemrecht en zij behoeven derhalve ook niet erkend te worden in de zin van artikel $2: 86 \mathrm{a}$ en $2: 196 \mathrm{a}$ of $2: 86 \mathrm{c} .52$

49. Het uitgangspunt voor de stemrechttoekenning aan de certificaathouder werd gevornd door het SER-advies inzake de structuurregeling. De SER stelde voor de certificaathouder rechtstreeks het stemrecht toe te kennen. De raad verslikte zich daarbij echter in de bewoordingen van art. 2.88 en 2:197 lid 4. De genoemde artikelen spreken immers van de rechren van de bewilligd certificathouder. Het voorstel van de SER liet daardoor geen andere conclusie dan that de vruchtgebroiker het stemrecht eveneens toekwam. E.C. Bos en JJ.A. Hamers, WPNR 6452 (2001), p. 645-646, alsmede uitgebreider E.C. Bos en JJ.A. Hamers, Shichting d Vereniging 2001/5, p. 89 en verder. De wetgever repareerde deze stemwerwarring en koos voor het systeem van de privatieve volmaclit. Bovendien introduceerde hij een expliciete uitsluiting wan de gelijkstelling van art. $2: 88$ en 2:197 woor deze wolmacht.

50 In het woorontwerp van de wijziging van Boek 2 BW in verband met de flexibilisering van de BV (hiernat het Voorontwerp) wordt een voorstel gedaan om de bewilligingscontroverse voor wat betreft dit type vennootschap voorgoed terzijde te schuiven. In de voorgestelde wijziging van artikel 2:197 lid 4 wordt niet meer gesproken van 'houders van met medewerking wan de vennootschap uitgegewen certificaten van aandelen", maar wan "houders wan cerfificaten van andelen waraan bij de statuten wergaderrecht is werbonden'. Aldus behoeft niet meer bekeken te worden of de certifitiaten met medewerking zijn uitgegeven, maar volstakt een blik in de statuten. Het voorgesteld art. 2:227 bepaalt dat aan bij de statuten aan certificaathouders vergaderrecht kan worden toekend. Vergelijk het Ambtellijk Voorontwerp wan 10 februari 2005. Gegevens zijn te verkrijgen op www.flexbv.eznt.

5. Ook in het Voorontwerp wordt gebruik gemaakt van cen gelijkschakeling met dle certificaathouder. Enkel het probleem van de bewilliging wordt in het woorstel geadresseerd. Vergelijk noot 50 supra.

52 Visser, diss, par. 14 alsook Van Gaalen, diss., nr. 392. Anders: M.Pl. van Sint Truiden, NTBR $1993 / 2$, p. 30 . Zie voor de bespneking van de erkenning $\$ 3.3$ van hoofdstuk IIl. 
De artikelen 2:88 en 2:197 lid 4 verschillen op één van punt van redactie. De vruchtgebruiker zónder stemrecht is slechts voorwaardelijk toegelaten tot de genoende rechten. De formulering daartoe in de artikelen $2: 88$ en 2:197 kent een subtiel verschil. De slotzin van artikel 2:88 lid 4 luidt:

'De vruchtgebruiker die geen stemrecht heeft, heeft deze rechten [de rechten van de bewilligd certificaathouder, ECB], tenzij deze hem door de statuten der vennootschap worden onthouden.'

De NV dient derhalve de niet-stemgerechtigde vruchtgebruiker expliciet in de statuten de certificaathouderrechten te onthouden. ${ }^{53}$ Artikel 2:197 lid 4 hanteert een ongekeerde hoofdregel. De met artikel 2:88 corresponderende regeling in de slotzin van lid 4 van artikel 2:197 luidt:

'De vruchtgebruiker die geen stemrecht heeft, heeft deze rechten, indien de statuten dit bepalen en bij de vestiging of overdracht van het vruchtgebruik niet anders is bepaald. ${ }^{54}$

De gedachte achter dil subtiele verschil in redactie lijkt te zijn dat de - voor wat betreft het rechtskarakter - open NV expliciet deze vruchtgebruiker dient te weren door zulks te bepalen in haar statuten. Het besloten karakter van de BV daarentegen brengt met zich mee dat de niet-stemgerechtigde vruchtgebruiker expliciet moet worden toegelaten tot de rechten van de bewilligd certificaathouder en dientengevolge, zoals hierna wordt betoogd, tot de kring van $2: 8 .^{55}$

53 Uit onderzoek naar de statuten van beursgenoteerde vennootschappen die alan de Amsterdamse beurs noteren (AEX on Midkap) blijkt dat deze vennootschappen wel degelijk aandacht besteden aan de positie van de bepenkt gerechtigde. Van de onderzochte vennootschappen welke aan de AEX noteien ontzegt circa $70 \%$ de niet-stemgerechtigde vruchtgebruiker expliciet de rechten van de bewilligd certificaathouder. Van deze groep ontzegt Unilever, blijkens de algemene bepalingen van de statuten, de bedoelde vrwchigebruiker alleen de vergaderrechten. De overige vennootschappen (30\%) hebben geen expliciete onthonding in thun statiten opgenomen en kennen dientengewolge de vruchtgebrtiker zonder stemreclnt de rechten van de bewilligd certificaathouder toe. Bij de onderzochte Midkap-vennootschappen ligt de verhouding lichtelijk anders. Blijkens de statuten krijgt de nietsterngerechtigde vruchtgebruiker hier vaker het woordeel van de twijfel: $40 \%-60 \%$. Zle voor een owerzicht van dit onderzoek Bijlage $A$.

54 In het Voorontwerp bijift deze zinsnede ongewijzigd.

55 Alsook Asser/Maeijer 2-1II (2000), nx. 224. MAEuER verwoordt krachtig: 'Blijkbaar is de gedachte dat bij de besloten wennootschap deze 'pottenkijkers' uitdrukkelijk moeten zijn toegelaten." 


\subsection{De kring van artikel $2: 8$}

\subsubsection{Inleiding}

De algemene bepaling ten aanzien vam rechtspersonen in artikel $2: 8$ betreft de introductie van het redelijkheids- en billijkheidscriterium in het rechtspersonen-reeht. De aanvullende werking van lid 1 en de derogerende werking van lid 2 van artikel $2: 8$ wormen samen een van de belangrijkste pijlers van ons rechtspersonenrecht ${ }^{56}$ Aanvankelijk werden de partijen die deel uitmaakten van deze redelijkheids- en billijkheidskring uitdrukkelijk genoemd. ${ }^{57}$ Lid 1 van artikel 2:8 huidt nu als volgt:

'1. Een rechtspersoon en degenen die krachtens de wet en de statuten bij zijn organisatie zijn betrokken, moeten zich als zodanig jegens elkander gedragen naar hetgeen door redelijkheid en billijkheid wordt gevorderd."

De formulering van lid 1 heeft er toe geleid dat men ook wel spreekt van institutioneel betrokkenen". ${ }^{58}$ Ondanks dat de vruchtgebruiker in de oude, limitatief opgesomde kring niet werd genoemd, wordt hij blijkens de parlementaire geschiedenis naar huidig recht wel degelijk expliciet tot deze institutioneel betrokkenen gerekend ${ }^{59}$ Het belang van de vraag of de vruchtgebruiker tot de genoemde kring behoort, hangt samen met de rechtsmiddelen die de institutioneel betrokkenen wordt geboden. Het voornaamste rechtsmiddel dat de institutioneel betrokkenen toekomt is dat van artikel $2: 15$. Besiuiten kumnen wegens strijd met de redelijkheid en billijkheid van artikell $2: 8$ worden aangetast. ${ }^{60}$

HAMERS stelt zich de vraag of elke beperkt gerechtigde tot de kring van artikel 2:8 dient te behoren. ${ }^{61}$ De parlementaire geschiedenis doet hierover geen uitdrukkelijke uitspraak. Zij spreekt slechts van de vruchtgebruiker en de pandhouder. Naar de mening van HAMERS is de kring in dat geval echter te ruim. Voor wat betreft de stemgerechtigde vruchtgebruiker of pandhouder is het evident dat deze tot de kring van

56 Vergelijk de inventarisutie van de literathor op dit pumt van I.M. Blanco Fernandez, in: 'Onderhe-

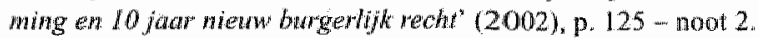

57 Artikel $2: 8 \mathrm{BW}$, woor 1992 vervat in artikel $2: 7 \mathrm{BW}$ noomde achtereenwolgens, de recht spersoon, luar leden of arandeelhouders, wj die deel witmaken van har organen en de fiouders van met medewerking der vennootschap uitgegeven certificaten van andelen. Vergelik (Losbl) Rechtspersonen (JB. Huizink); art: 8 - aant. 1 alsook Asser/Van der Grintem-Maejjer 2 II (1997), mi. 46.

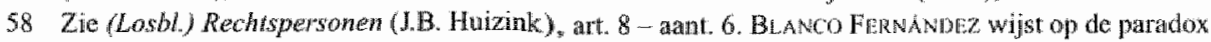
in deze benaming (de ondernemingsiaad is waarschijnlijk niet institutioneel betrokken", terwij] de

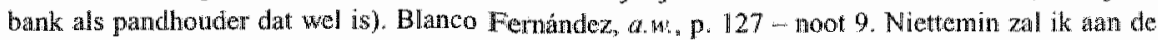
verzamelnearn vast houden.

59 Assem/Van der Grinten-Maejer 2-II (1997), wr. 46 .

60) Art. 2:15 lid 1 sub b.

61 J.J.A. Hamers, diss RC (1996), p. 68. 
artikel 2:8 behoort. Dankzij het stemrecht kan de vruchtgebruiker of pandhouder actief deelnemen in de besluitvorming van de vennootschap. Het toestaan van de stemrechtoverdracht door de vennootschap ${ }^{62}$ geeft blijk van de acceptatie van het toetreden van de beperkt gerechtigde tot de kring van artikel 2:8. Dezelfde redenering moet ten grondslag liggen aan het toetreden van de beperkt gerechtigde zónder stemrecht tot deze kring. lk deel de mening van HAMERS wanneer hij betoogt dat enkel van een vennootschapsrechtelijke verhouding zonder stenurecht gesproken kan worden, wanneer de beperkt gerechtigde beschikt over de rechten van houders van bewilligde certificaten. ${ }^{63}$ Het vorenstaande wordt kracht bijgezet door een citaat van TIMMERMAN die stelt dat bij de organisatie van de rechtspersoon betrokken personen 'een ieder is die op grond van de wet of de statuten rechten of plichten heeft die door gedragingen, die zich binnen de sfeer van de rechtspersoon afspelen, rechtstreeks beïnloed kumnen worden'. ${ }^{64}$ Wil de beperkt gerechtigde beschikken over deze rechten dan heeft de vennootschap daar in beginsel de hand in gehad en daarmee de vruchtgebruiker of pandhouder expliciet toegelaten tot de kring van artikel $2: 8 .^{65}$

62 Zie hierwoor \$6.2.1.

63 Kennelijk anders: (Losbl) Rechtspersonen (J.B. Huizink), art. 8- aant. 6. Huizink rekent enkel vruchitgebruikers nét stemrecht tot de kring van artikel 2:8. Dit wekt bevreemding nu hij de nietbewilligde certificathouder onder omstandigheden well tot de genoemde kriag rekent. Dat de nietstengerechitigde wuchtgebruiker volgens hem kennelijk buiten de boot valt, komt temeer oniredelijk voor nu de niet-bewilligde certificathouder in de visie van HUizINK zijn plaatsje in diezelfde boot dankt an het reit dat de certificathouder "wan het certificaat rechiten jegens de vemootschap [kan] onilenen'. Dat de weliswar niet-stemgerechtigde, maar wel stantair begunstigde vruehtgebruiker aldus werstoken bliftt van een gelijkwaardige positie lijkt mij moeilijk te verantwoorden. VISSER neemat in haar proefschrift helaas niet expliciet stelling ten aanzien van het onderhavige vraagstuk, hetgeen valt te betreuren mu de toegang tot de kring van art. 2:8 voor de vruchtgebruiker van groot belang kan zijn. VISSER stelt echter wel dat HAMERs het feit dat de wetgever spreekt van wruchtgebruikers en panthouders van aandelen (zonder de nuancering ten aanzien van het stemrecht of de certificasthouderrechten) miskent (Visser, diss., par. 90-noot 218). Zij miskent echter op haar beurt het feit dat de wetgever wel spreckt van 'met medewerking van de wennootschap witgegeven ' certificaten. De donrwerking varn deze specificering neem een prominente plaats in in het sluitende betoog van HAMERs.

64 C.W. de Monchy en L. Timmerman, 'De nieume algenene bepalingen van Boek 2 BW' (1991), p. 49. Het verieiste van het ontlenen van rechten aan de statuten brengt MAkifler ertoe de houder van winstbewijzen wiens rechten statutair zijn geregeld te rekenen tot de institutioneel betrokkenen. Hët belang wan de houder van een winstbewijs kan immers geschaad worden door het winstbestem. mingsbesluit. Helaas lijkt een zelfde conclusie voor de vruchtgebruiker, wiens belang eveneens door het betrokken besluit kan worden geschaad, niet zonder meer weggelegd voor âlle vruchtgebruikers. De redenering van MAEUER - en diens werwijzingen naar HR 27 januari $1956, N J 1956,48$ (Rotrerdamse Droogdok Mij.) en HR 11 januari 1963, NJ 1964, 433 m.nt. GJS (Rubber Cultuu Mij.) - volgend kan de vruchitgebruiker wiens rechtspositie niet statutair wordt erkend geen beroep doen op de rechten uit art. 2:8. Asser/Van der Grinten-Maeijer 2-II (1997), nr. 46.

65 Zie voor de bespreking van deze gelijkschakeling door wet en/of statuten $\$ 2.3$. Voor de goede orde herhaal ik dat de wet wit gaat van een systeem waarin de BV indien gewenst, deze vruchtgebruiker de rechten statutair dient toe te kennen (positieve statutaire bepaling). De NV daarentegen dient deze vruclutgebruiker de certificaathoudersechten statutair expliciet te onthouden (negatieve bepaling). 
Omgekeerd, wanneer de vennootschap de genoemde gelijkschakeling is tegengegaan, kan dat geïnterpreteerd worden als het weren van de betreffende beperkt gerechtigde uit de redelijkheids- en billijkheidskring.

De conclusie dat aldus de vruchtgebruiker zonder stemrecht en zonder certificaathoudersrechten niet tot de genoemde kring behoort kan tot op zekere hoogte worden gerelativeerd. Artikel 2:8 opent voor de institutioneel betrokkenen het specifieke normenkader van het vennootschapsrecht met daaraan - voomamelik - gekoppeld het rechtsmiddel uit artikel $2: 15$. De norm die in artikel $2: 8$ is opgenomen heeft echter ook te gelden buiten deze kring. ${ }^{66}$ Het feit dat deze norm geldt voor alle betrokkenen buiten de kring en hun gerechtvaardigde belangen derhalve ook meegenomen dienen te worden, maakt het gerechtvaardigde belang van de vruchtgebruiker relatief onbeduidend. De algemeen geldende redelijkheids- en billijkheidsnorm vormt aldus een druppel op de gloeiende plaat voor de rechtsbescherming van de vruchtgebruiker zonder lidmaatschapsrechten.

\subsubsection{Een mogelijke uitwerking van artikel 2.8 - het winstbesluit}

Wanneer de vruchtgebruiker tot de kring van artikel $2: 8$ behoort, krijgt hij op grond van artikel $2: 15$ een belangrijk rechtsinstrument in handen. Hoe relevant een dergelijk instrument is, kan worden geillustreerd aan de hand van het besluit dat voor de vruchtgebruiker van levensbelang is: het winstbeshit.

\subsubsection{Het winstbesluit en de aandeelhouder}

De jurisprudentie rond het winstbesluit kent een duidelijke basis in artikel $2: 8 .^{67}$ Zoals bij het nemen van elk besluit in een rechtspersoon is het hanteren van de redelijkheids- en billijkheidsnorm ook hier een belangrijke verplichting voor het besluit nemende orgaan. Allereerst oordeelde het Hof te "s-Gravenhage in "Van Rees/Smits" dat het besluit tot het verdelen van - in dit geval het restant van - de winst zodanig moet zijn dat het de belangen van de minderheidsaandeelhouders niet schaadt. ${ }^{68}$ Het Hof sloot zich aan bij de redenering die de Rechtbank er eerder toe bewoog het winst-

66 Vergelik ook Van Schilfgarde/Winter (2003), n. 8. Wister is van mening dat deze norm het gehele privaatrech bestrijkt.

67 Strikt genomen wordt in deze paragraaf niet alleen de relatic ussen art. $2: 8$ en hett withstbesluit besproken. Naast art. 2:8 kan tevens bet onquêtemecht in steling worden gebracht oni dividenduitkering af te dwingen. Nu de bespreking wan de antasting wan een of meer wintbestuiten maatlow van art. $2: 8$ overloopt in het enqueterecht zai dit latsti rechtsmiddel eveneens in dit kaden worden besproken. Een dergelijke werkwijze komi de leesbartheid mati min smakk ten goede.

Hof "S-Gravenhage 1 oktober 1982 , H 1983, 393 (Wan Rees/Smits). 
besluit te vernietigen. ${ }^{69}$ De Rechtbank Dordrecht gebruikte een formulering die ongetwijfeld uit het hart van de vruchtgebruiker is gegrepen:

Alle onstandigheden in aanmerking genomen, (..) kon - ondanks het belang van interne financiering en een financieel sterke positie van de vennootschap, met name met hef oog op de weinig rooskleurige vooruitzichten voor de Nederlandse scheepsbouw - geen redelijk handelende AvA komen tot het besluit on de restantwinst zodanig te verdelen, dat die - minderheid van - aandeelhouders, die woor het genieten van winst uit de resultaten van de vennootschap uitsluitend op het uit te keren dividend zijn aangewezen [cursief van mij, $E C B$ ], zelfs niet een redelijke rente verkregen voor het door hen in de vennootschap geïnvesteerde kapitaal, laat staan een aandeel verkiegen in het gunstig exploitatieresultaat. ${ }^{\text {po }}$

De aandeelhouders die in 'Van Rees/Smits' door het besluit tot algehele reservering van de meerderheidsaandee/houder werden uitgehongerd, werden aldus tegemoet gekomen. Het belang van de minderheidsaandeelhouder bij de uitkering van dividend werd daarmee erkend ${ }^{71}$ Slechts wanneer er aanvaardbare, redelijke gronden worden aangevoerd kan de winst worden gereserveerd. Het Hof Arnhem onderstreepte deze gedachtegang door in zijn uitspraak van 26 mei 1992 "Uniwest Group BV'72 eveneens een onredelijk besluit tot winstbestemming te vernietigen. In dit geval forceerde de meerderheidsaandeelhouder een grootschalige reservering van de winst, omdat zijn mede-aandeelhouders concurrerende handelingen verrichtten.

69 De vernietiging werd gebaseerd op ant. 2:11 BW (oud), hetwelk spreekt wan "de geede trouw" Howel in het verteden de verhouding tussen dit artikel en de redelijkheid en billijkheid van het foenmalige artikel $2: 7$ niet onomstreden was, werd bij de wijziging in 1992 deze onzekerheid weggepoetst. Beide opvolgers wan de artikelen, respectievelijk art. $2: 8$ en $2: 15$, spreken wan de redelijkheid en billijkheid. Zie over de controverse tussen goede trouw en de redellikheid en billijkheid; (Lorbl.) Rechispersonen (J.B. Huizink), art. 8-aant. 5; Asser/Van der Grinten-Maeijer 2-11 (1997), ar. 46 alsmede nitgebreider M. Koelemeijer, diss. RL (1999), p. 21-23.

70 'Van Recs/Smits', ro. 5.

7l Dit belang neemt natuulijk sterk toe wanneer het aandeelhouders in een $B V$ betreft. $Z$ ij beschikken niet over het alternatief on de aandelen desnoods te verkopen. Koelemeijer, diss., p. 170; B. Bier, dis.s. $B U$ (2003), p. 69. Overigens biedt de wet naast het gecombineerde rechtsinstrument van art. 2:8/2:15 en de hierna te behandelen enquêtuprocedure nog een mogelijkheid voor de drooggelegde aandeelhouder. Art. 2:343 biedt de andeelhouder die verstoken blift wain dividend de mogelijkheid wit te treden door zijn mede-aandee thouders te laten weroordelen tot het overnemen van zijn aandelen. Meer hierover in 83,3 alwaar deze uittreding in het kader wan de geschillenregeling wordt besproken

72 Hof Arnhem 26 mei 1992, NJ 1993; 182 mat. Ma (Uhwest Group BD). 
Het Hof oordeelde dat:

'(..) een dergelijk nadeel slechts [kan] worden opgelost wia een wordering tot schadevergoeding en wet door vaststelling van een lager diwidend dan waarop andeelhouders in redeligheid aanspraak kunnen maken. ${ }^{73}$

Het Hof Amhem ging er zelfs toe Over een - redelik - dividend betadbaar te stellen. ${ }^{74}$ Alhoewel deze laatste beslissing door het Hof summier werd gemotrveend, vond zij in de literatuur vuchtbare grond. ${ }^{35}$

De aandeelhouder beschikt echter zelf ook over een rechtsmiddel on de aitkering van dividend door de vennootschap te bewerkstelligen: het enquêterecht. In de uitspraken "Sluis BV" en "Kerstens" oordeelden respectievelijk de Hoge Raad en de $O K$ in een enqueteprocedure dat het structuteel reserveren van de winst een gegronde reden kan vormen om aan een juist beleid te twijfeten. Het dividendbeleid valt derhalve evenzeer onder deze beleidstoets. ${ }^{78}$

\subsubsection{Het winstbesluit en de vruchtgebruiker}

De zojuist geschetste mogelijkheden voor de naar dividend verlangende aandecl houder khinken de wruchtgebruiker naar alle warschijnlijkheid als muziek in de oren. Naar mijn smaak staan de genoemde rechtsmiddelen ook de vruchtgebruiker ten dienste. Tenslotte geldt ook voor de vruchtgebmiker die tot de kring van artikel 2:8 behoort, dat winstbesluiten ook zijn belangen niet onnodig mogen schaden en derhalve jegens hem niet onredelijk mogen zijn. Bij haar besluitvorning dient de AvA zich dus bewust te zijn van de gerechtvardigde belangen van de aanwezige

73 "Uningest Group BV', ro. 4

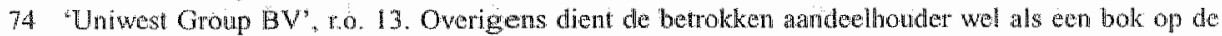
haverkist te zitten, want de redenering gat allen op woor de winst wan dat bepalde boelchar aldus

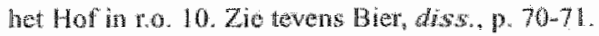

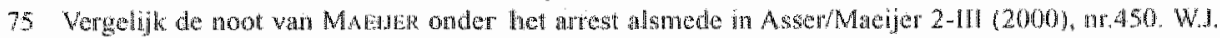

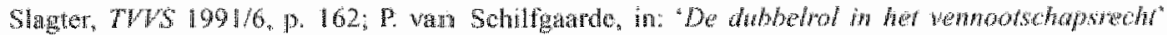

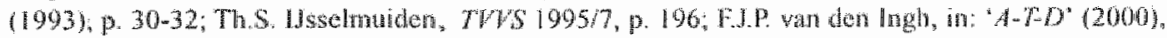

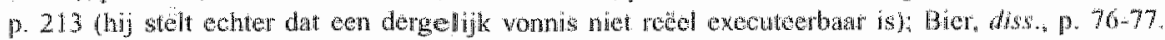

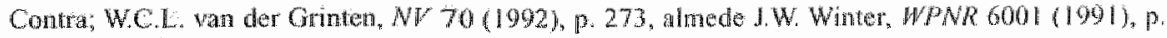

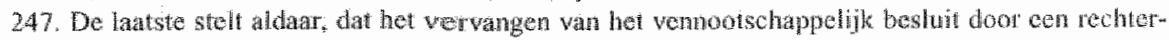
ligk vonmis slechts mogelik is wannerer de wet zulks bepatt:

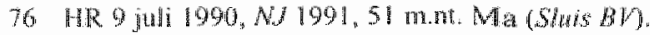

77 Hof Amsterdan (OK) 15 september 1995, WJ 1995, 540 (Kersems).

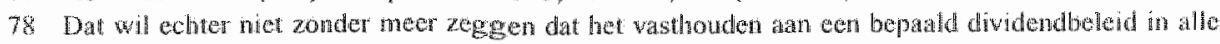

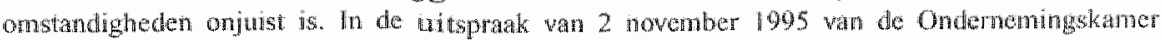

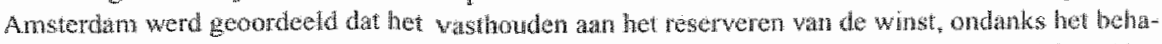

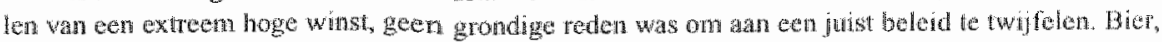

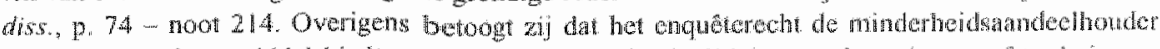

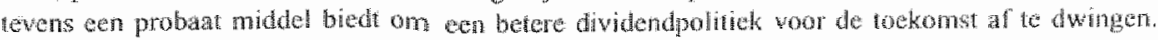
Biel: diss.: 9.75 
vruchtgebruiker. De vruchtgebruiker is immers, in de woorden van 'Van Rees/ Smits", aangewezen op de uitkering van dividend door de vennootschap ${ }^{79}$ De stemgerechtigde kan reeds in de besluitvorming zelf zijn belang kracht bijzetten. De nietstemgerechtigde wruchtgebruiker zal slechts achteraf kunnen optreden door een beroep te doen op artikel 2:15. Het mogelijke argument dat in dat laatste geval de bezwaarde aandeelhouder zelf bepaalt hoe hij zijn stem uitbrengt snijdt naar mijn smaak geen hout. De vestiging van het recht van vruchtgebruik brengt met zicli dat de aandeelhouder niet ]anger klakkeloos zijn eigen belang kan nastreven wanneer hij zijn stem uitbrengt in de AvA. De opmerking van de wetgever dat de aandeelhouder het belang van de vruchtgebruiker niet zal mogen schaden getuigt van deze opvatting. ${ }^{80}$ Het vruchtgebruik op zijn aandeel houdt in dat zijn recht op dividend goederenrechtelijk aan de vruchtgebruiker is toegekend. In het geval er in de AvA besloten wordt over een restantwinst dient hij in het belang van zijn vruchtgebruiker te stemmen voor dividend uitkering. Stemt hij voor een evident onredelijke winstreservering en rolt vervolgens deze winstreserving als besluit uit de AvA dan schenden zowel de aandeelhouder als de AvA de norm van artikel $2: 8$. Stelt de rechter een vruchtgebruiker op grond van artikel 2:15 in het gelijk dan is een toekenning van een redelijk dividend door de rechter aan de vruchtgebruiker alleszins voorstelbaar. Bovendien kan het enquêterecht in bijzondere gevallen ${ }^{81}$ de vruchtgebruiker terzijde staan om een voor hem redelijke dividendpolitiek nu en in de toekomst te verwezenlijken. ${ }^{82}$ De vruchtgebruiker die buiten de kring van artikel $2: 8$ valt kan als gevolg van dit feit zijn belang niet op eigen titel rechtsstreeks in de vennootschap verdedigen. Zijn belang in de vennootschap kan slechts bij monde van de bezwaarde aandeelhouder in de vennootschap worden verdedigd.

\subsubsection{Conclusie}

De rechtspositie van de vruchtgebruiker in een kapitaalvennootschap wordt in belangrijke mate ingekleurd door de statuten der vennootschap. Vooreerst zijn het de statuten die bepalen in hoeverre het stemrecht aan de vruchtgebruiker kan worden

79 In het kider van het redelifk dvidend is op gewezen dat het belang van de andeelhowder in de BV sterker is dan dat van de NV, omdat hij net zonder meer kan werkopen (noot 71 supra). Voor de vuchtgebuiker gedt nar heenende leer drijd dat dit alternatief hem niet ten dienste stat.

80 Vergelijk de $\$ 6.2 .1 .3$.

\$1 Allowew de toegang tot het enquêterecht op grond van de gelijkstelling met de bewilligde certificaathouder yoor de vruchtgebruiker binnem handbereik is, moet daarnaast nog voldan zijm aan de kipital woow warden wan art. 2:346 lid 2. Bovendien geld in dit verband natturlijk ook hoe groter de betrokken vennootschap, hoe klemer het gerechtwardigd belang wan de vnuchtgebruaker. Het kont mij voor dat slechts in kleine, besloten wennootschappen (ook de besloten NV reken ik hier toe) het enquêterecht als whinum nemedium door de noodlijdende vruchtgebruiker kan worden ingezet.

82 In gelijke zin voor de centificathonder; K. Frielink, F\&O 1997/7-8, p. 85-87. 
overgedragen. Daarnaast kumnen alleen de statuten voorkomen, dat via volmachtverlening de aandeelhouder zijn vruchtgebruiker het stemrecht - weliswaar op niet privatieve wijze ${ }^{83}$ - gunt. Naast het stemrecht bepalen de statuten tevens het toelaten van de niet-stemgerechtigde vruchtgebruiker tot de vennootschapsrechtelijke kring van artikel $2: 8$. In dit hoofdstuk heb ik betoogd dat deze toegang samenliangt met de toekenning van de rechten van de bewilligde certificaathouder. De niet-stemgerechtigde aandeelhouder en de stemgerechtigde vruchtgebruiker ontvangen op dwingendrechtelijke wijze deze rechten ${ }^{84}$ en behoren derhalve zonder meer tot de redelijkheids- en billijkheidskring. De niet-stemgerechtigde vruchtgebruiker is zoalls reeds vermeld, afhankelijk van de op hem van toepassing zijnde statutaire bepalingen.

Het besproken instrumentarium is voor de vruchtgebruiker van essentieel belang. Het samenstel van stemrecht, vergaderrechten en het specifieke enquêterecht bieden een bruikbaar palet aan instrumenten voor de verdediging van zijn belangen.

\subsection{De geschillenregeling}

\subsubsection{Inleiding}

Na sterke geluiden uit de praktijk en de literatur omtrent de behoefte aan een geschillenregeling voor de kapitaalvennootschap bracht de Commissie Vennootschapsrecht in 1975 een advies uit aan de Minister van Justitie over de invoering van een dergelijke regeling. ${ }^{85}$ Het advies leidde tot de in 1988 geintroduceerde wettelijke geschillenregeling. ${ }^{86}$ De regeling kent een dwingend-rechtelijk, zij het subsidiair, karakter. Slechts wanneer een eventuele statutaire regeling geen mogelijkheid biedt wit het geschil te komen ${ }^{87}$, is de weg naar de wettelijke geschillenrege-

83 De volmachtverlening kent geen privatief karakter. Vergelijk \$6.2.1.4.

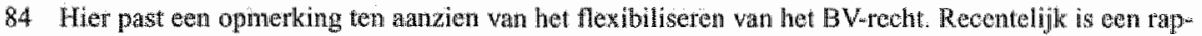
port verschenen van de Commissie De Kluver getiteld "Vereenvoudiging en floxibilusering wan het Nederlandse B Frecht" (hierna "Rapport flexbilisering BV') Belangrijk thentin in dit rapport is de versoepeling van het dwingendrechtelijk karakter wan het BV-recht. Ziw net name pagina 2 on verder. Mocht cleze versoepeling doomzetten dan dient de vruchtgebruiker op zijn hoede te zijn. Hoeft de vennootschap bij het invullen van haar statuten zich minder gelegen te laten aun de dwingendrechtelike regelingen wan boek 2 dat kan aldus unbreak gemaakt worden op de besproken techten van de vruchtgebruiker die vooralsnog dwingendrechtelijk in de wet zijn verankerd. Blijkens het Voorontwerp (verge vruchtgebruiker te tomen.

85 Zie voor een overzicht wan de geschiedenis wan deze regeling (Lasbl, Rechtspersonen (A.F.M. Dorresteijn), Tittel 8 - Inlleiding; alsook Asser/Maejer 2-III (2000), wr. 492 ,

86 Ingevoerd bij de Wet wan 10 november $1988,5 \mathrm{~b}, 1988,516$.

87 MAEnER wugt er op dat zulks niet vertald mag worden al's "de statutaire regeling beef nict tor een bewredigende uitkomst geleid." Asser/Maejer 2 III (2000), nr. 495 . 
ling geopend. ${ }^{80}$ Deepassing ervan richt zich op de BV en de NV met een sterk besloten karakter.

De regeling voorziet in drie oplossingen voor een conflictsituatie in de aandeelhoudersvergadering ${ }^{90}$ :

a) artikel $2: 336$, uitstoting van een aandeelhouder

b) artikel 2:343: uittreding van een aandeethouder

c) artikel 2:342: ontineming van stemrecht aan een vruchtgebruiker of pandhouder

Omwille van de helderheid zullen de posities van de aandeelhouder en de vruchtgebruiker steeds los van elkaar worden besproken voor elk van de artikelen.

\subsubsection{Uitstoring}

Wanneer een aandeelhouder door zijn gedragingen het vennootschappelijk belang zodanig schaadt, dat het voortduren van zijn aandeelhouderschap in redelijkheid niet kan worden geduld, biedt artikel 2:336 de andere aandeelhoudlers de mogelijkheid deze aandeelhouder uit te stoten. ${ }^{92}$

\subsubsection{De aandeethouder}

Het eerste dat opvalt in de regeling is dat het moet gaan om "gedragingen van de aandeelhouder': Dit betekent dat de vruchtgebruiker, als potentiële veroorzaker, voor de toepassing van artikel 2:336, alsmede voor de toepassing van artikel $2: 343$ hetwelk hierna aan bod komt, buiten schot blifft.

Welke gedragingen wan de aandeelhouder kunnen er nu voor zorgen dat een gedwongen overdracht plaatsvindt? De MvT licht 'gedragingen' nader toe met de

88 Zie voor een uitgebreide bespreking wan dit artikel 2:337. J. Bertiams, in. 'Overnemen. Een Hele ondememing" (1998), p. $71-75$.

89. Het bosloten karakter wan NW blijki uit de vereisten van art. 2.335 lid 2. Het genoernde lid eist dat de statuten wan deze 'besloten WW' (a) uitsluitend aandelen op mam kemen, (b) een blokkeringsiogeling bevatien on (c) niet toelaten dat met medewerking wan de vennootschap certificaten aan toondet worden uhtgegeven. Zulks betreft overigens een titbreiding wan thet toepassingsgebied voorgesiefl door do Commossie Vermootschapsrecht in haar advies.

90 Reeds hict disnt de kanttekening geplatst te worden dat de huidige gesehillenregeling nog weinig voorstanders kent. In de titeratun zijn verschillende voorstellen gedatan on de huidige regeling aan to passen. Zie voor een werzicht wan deze voorstellen A.F.A. Leitten, in: 'Gesichiffen Corporate Lirigation ${ }^{2}(2003)$, p. 74. Hoewel deze voorstellen nict geleid thebben tot ache wan de wetgever heeft de Comnussie De Kluiver in thar rapport voor de vereenvoudiging wan het BV-recht aangekondigd de geselillenregeling mee zullen nemen. 'Rapport flexibilisering $B V$, p. 14-15.

91 Zie Van Schilfgarde/Winter (2003), nr. 114; alsmede Asser/Maeijer 2-IT (2000), nir. 494. De MvT

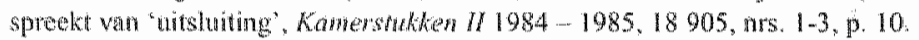

92 Voor de goede orde; de vordering kan ingesteld worden door éen of meer anandeethonders die alleen of tezamen meer dan 1/3 van het geplatsk kapitaal vertegenwoordigen (art. 2.336 lid 1 eerste zinj. 
opmerking dat het gearagingen in de hoedanigheid wan aandeellouder moeten betreffen. De gedragingen moeten er toe leiden dat het functioneren van de vennootschap in gevaar komt, omdat bijvoorbeeld de besluitvorming wordt verland. ${ }^{93}$ Kortom, de aandeelhouder moet zich in zijn hoedanigheid van andeelhouder misdragen. Daarenboven dient het belang van de vennootschap door deze misdragingen geschaad te worden. De norm "het belang van de vennootschap" word verklaard door de ingrijpendheid van de regeling. De aandeelhouder wordt het eigendom ontnomen en de rechtwardiging moet gevonden kunmen worden in een overkoepelend belang. ${ }^{\text {as }} \mathrm{De}$ twee eisen - misdragingen van de aandeehouder en schade voor het belang van de vennootschap - zijn cumulatief en causaal. Zulks blijkt onder meer uit een reactie in de MvT op een voorstel van het Genootschap van Bedrijfsjuristen in 1978 . Het genootschap stelde voor dat, indien de aandeelhouders elkar beconcurreren buiten de vennootschap om, van de aandeelhouders niet gevergd kan worden de concurtent te dulden. Echter, de wetgever achtte deze loskoppeling van de twee eisen cen onaanvaardbare verruiming van (de grond voor toepassing van) de geschillenregeling:

'Loskoppeling van het gedrag van de aandeelhouder en het belang van de vennootschap, zou het toepassingsgebied van de geschillenregeling echter te ver uitbreiden. 9.5

Hoewel uit voorgaand citalit in samenhang met de wettekst de koppeling van stemgedrag (lees: de verlamming van de besluitvorming) en directe schade voor het vennootschappelijk belang een vast omlijnd gegeven lijkt te zijn, bestaat er in de literatuur enige discussie. Wanneer de wettekst sec bekeken wordt, menen SLAGTER ${ }^{96}$ en EMMERIG ${ }^{97}$ dat deze een ruimere toepassing toelaat dan op grond van de MWT verwacht zou worden en zij staan deze verruiming voor. De mogelijkheid om aldus door middel van de geschillenregeling misbruik van (voor)wetenschap en concurrerend handelen door aandeelhouders 98 aan te pakken, benoemen zij als argument voor deze verruming. VAN SCHLFGAARDE pleit eveneens voor uitbreiding van 'de gedragingen' naar de privé sfeer en betitelt het arrest "Van Eyl/Nootebos I", dat zijn stelling bestrijdt, als onjuist. ${ }^{100}$ BERTRAMS meent in de uitspraak van de OK in "Mulled Must" ${ }^{10 n}$ een woorzichtige oprekking van het begrip gedragingen te zien. ${ }^{102}$ Laatste-

93 Kamensukken U1 1984-1985, 18905, nrs. Im, P. 16. Asser/Maeijer 2-1II (2000), nt. 496.

94 Zie Asser/Maeijer 2-lll (2000), ar. 496 .

95 Kameschklken II $1984-1985,18905$, wars. 1-3, p.16-17.

96 WJ. Slagter, $T$ VVS $1985 / 5$, p. 127 .

97 B. Enmerig, $4 A 1988, \mathrm{p}, 321$.

98 Anders ten anzien van concurrente door aandechouders: W. Westbroek, WPNR 5759 (1985), p. 714 .

99 Hof Amstertan(OK) 22 oktober 1992 , Ny 1999, 411 (Kan EylNootebos D.

100 Van Schilfgarde Wituter (2003), nr. 114 .

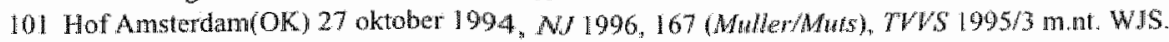

102 Bertrams, a. H, p. 85 . 
lijk heeft ook BULTEN betoogd dat de gronden woor uitstoting uitbreiding behoeven: 103

Geconcludeerd kan worden dat; ondanks de geluiden in de literatuur, blijkens jurisprudentie de aandeelhouder enkel voor uitstoting vatbaar is, wanneer hij met zijn stemrecht het belang van de vennootschap schaadt. Daaruit wolgt dat een niet-stemgerechtigde aandeelhouder, die zijn stemrecht heeft overgedragen aan de vruchtgebruiker, niet kan worden uitgestoten eenvoudigweg omdat hij geen schade kan aanrichten in de zin van artikel 2:336.

\subsubsection{De vruchtgebruiker}

In het geval een aandeel is bezwaard met een recht van vruchtgebruik rijst de vraag in hoeverre de vruchtgebruiker bij een geschillenregeling betrokken kan raken. De grond voor uitstoting ex artikel 2:336 richt zich met name op de gedragingen van de aandeelhouder en in het bijzonder het stengedrag van de aandeelhouder. Het is derhalve van belang in een situatie waarin een aandeel bezwaard is met een recht van vruchtgebruik te bepalen aan wie het recht wan stem toekomt. Komt het stenrecht aan de vruchtgebruiker toe dan wordt de mogelijkheid tot uitstoting van de aandeelhouder ernstig bemoeilijkt. De aandeelhouder kan immers niet op zijn stemgedrag worden aangesproken nu hij niet stemgerechtigd is. Uitstoting is niet uitgesloten, maar gezien de huidige benadering van 'gedragingen van de aandeelhouder' ex artikel 2:336 lijkt het moeilijk voorstelbaar. Zullks is bepaald niet het geval wanneer de betrokken aandeelhouder zijn stemrecht heeft behouden. De stemmende aandeelhouder kan de besluitvorming blokkeren en daarmee het belang van de vennootschap schade toebrengen. Indien zijn medeaandeelhouders tot uitstoting overgaan komt de vruchtgebruiker in een lastig parket terecht. Het aandeel waarop het recht van vruchtgebruik rust moet door de aandeelhouder gedwongen worden overgedragen. Helaas blijkt de weg naar de potentiële elegante oplossing van overdracht aan de vruchtgebruiker uitgesloten. De president van de rechtbank Rotterdam oordeelde in 'Zegers/ Zegers"104 dat de regeling geen mogelijkheid bood de aandelen over te dragen aan een derde (in de uitspraak een stichting). Het aandeel zal derhalve overgedragen moeten worden aan een van de medeaandeelhouders. De goederenrechtelijke kwaliteit van het recht van vruchtgebruik houdt echter in dat het vruchtgebruik op het over te dragen aandeel blijft rusten. Krachtens "droit de suite" ontvangt de verkrijgende medeaandeelhouder een aandeel dat bezwaard is met het recht van vruchtgebruik. Hoewel het bestaan van het beperkte recht ongetwijfeld meegenomen kan worden in de waardering van het betrokken aandeel, lijkt de aldus ontstane situatie voor partijen verre van ideaal. Deze conclusie wordt versterkt wanneer men bedenkt dat de bevoegdhe-

103 C.D.J. Bulten, WPNR 6605 (2005), p. 47.

104 Pres. Rb Rotterdan 18 juni 1990, KG 1990,259 (Zeger:/Zegers). 
den van de vruchtgebruiker ver kunnen reiken. ${ }^{105}$ Een mogelijke oplossing voor deze situatie is dat de hoofdgerechtigde en de vruchtgebruiker besluiten het aandeel onbezwaard te vervreemden. Aangenomen kan worden dat, omdat de vruchtgebruiker en aandeelhouder tezamen bevoegdelijk over het goed beschikken, krachtens de substitutieregel het recht van vruchtgebruik vervolgens komt te rusten op hetgeen voor het vervreemde aandeel in de plaats treedt. De betrokkenheid bij de vennootschap gaat hierdoor evenwel voor de vruchtgebruiker verloren.

\subsubsection{Conclusie}

Zoals reeds beschreven in het eerste deel van deze paragraaf is een aantal omstandigheden van belang indien de andere aandeelhouders een medeaandeelhouder kunnen dwingen zijn aandeel te vervreemden. Voor wat betreft de uitstoting van een aandeehouder is vooralsnog zijn stemgedrag als aandeelhouder doorslaggevend. Het vennootschapsrecht geeft geen uitsluitsel over de vraag wat het lot is van de vruchtgebruiker van een wegens uitstoting over te dragen aandeel. Het goederenrecht beschermt de vruchtgebruker met het beginsel van 'droit de suite', maar de vruch"gebruiker kan wellicht verkiezen het schip met de aandeelhouder te verlaten en een vruchtgebruik te ontvangen op hetgeen voor het aandeel in de plaats treedt.

Indien de aandeelhouder zijn recht van stem heeft overgedragen aan de vruchtgebruiker maakt dit hem weliswaar minder vatbaar voor uitstoting, maar zijn vermogen om de besluitworming te beïnvloeden is dan ook sterk verminderd. Vooralsnog zijn er geen overtuigende argumenten aan te treffen op grond waarvan aangenomen kan worden dat de aandeelhouder zonder stemrecht zich zodanig kan gedragen dat bij voor uitstoting vatbaar wordt.

\subsubsection{Vittreding ${ }^{106}$}

De aandeelhouder die door gedragingen van een of meer medeaandeelhouders zodanig in zijn rechten of belangen wordt geschaad dat het voortduren van zijn aandeelhouderschap in redelijkheid niet meer van hem kan worden verwacht, kan zijn medeaandeelhouders dwingen zijn aandelen over te nemen (artikel 2:343) ${ }^{107}$. De aandeelhouder wordt kort gezegd 'beklemd' of 'benard". ${ }^{168}$ Het grootste verschil met de uitstoting is het toepassingsgebied. Daar waar bij uitstoting de jurisprudentie een vrij nauwe interpretatie van gedragingen hanteert in het kader van 'belang van de vennootschap', zijn de criteria bij uittreding wat praktischer van aard.

105 Vergelijk $\$ 5.5$.

106 Van Schilfgaarde/Winter (2003), nr. 115; alsmede Asser/Maeijer 2-1ll (2000), mr. 494

107 Soms gaan de vordering tot uitsiuiting en uittreding samen. Zie voor deze samenlloop uitgebreider (Losbl.) Rechtspersonen (A.F.M. Dorresteijn), Titel 8 Inl - aant 3.

108 Kannerstukken I/ 1984 - 1985, 18905 , nr. 3, p. 6. Asser/Maeijer 2-III (2000), nr. 504. In de jurisprudentie richt de beoordeling van een verzoek ex art. 2:343 zich derhalwe op de vraag of de betrokken aandeelhouder zich 'in en benarde positie bevindt of zal bevinden'. 
Ten eerste is de invulling van de term 'gedragingen' ruimer. Alle gedragingen van medeaandeelhouders kuninen grond zijn de eis in te stellen en dat hoeven blijkens de rechtspraak niet eens misdragingen te zijn ${ }^{109}$ Niet alleen kan het gedragingen als aandeelhouder betreffen, maar ook gedragingen als bijvoorbeeld bestuurder. ${ }^{10} \mathrm{Con}$ currerend handelen van de medeaandeelhouder is hier (wel) voldoende grond voor het instellen van de vordering. "Daarnaast gaat het on het belang van de aandeelhouder dat geschaad wordt. Een aanzienlijk concreter belang.

Opvallend is dat géén rekening wordt gehouden met de stemgerechtigde vruchtgebruiker. De vraag is of zulks tot problemen kan leiden. Naar mijn smaak niet snel. De belangen welke geschaad werden in de aangehaalde casus ${ }^{112}$ betreffen bijvoorbeeld het belang bij dividenduitkering. Besluit de meerderheid van de AvA de bezwaarde aandeelhouder en zijn vruchtgebruiker uit te hongeren, dan kan het recht van uittreding - naast de reeds behandelde rechtsmiddelen ${ }^{13}$ - een oplossing bieden waarbij ook de vruchtgebruiker gebaat is. De vruchtgebruiker deelt als slachtoffer in dat geval het lot van de bezwaarde aandeelhouder en zij kunnen besluiten tot het instellen van een uittredingsverzoek. Er lijkt niettemin sprake te zijjn van een lacune. De stemgerechtigde vruchtgebruiker kan immers een minderheidsaandeelhouder het leven zuur maken met zijn stemgedrag zonder dat deze aandeelhouder aanspraak kan maken op zijn recht op uittreding. Tenslotte betreft het gedragingen van de vruchtgebruiker en niét gedragingen van een medeaandeelhouder zoals omschreven en vere ist in artikel 2:343. Wanneer deze aandeellhouder (samen met eventuele medeaandeelhouders) de drempel van artikel 2:342 niet haalt ${ }^{14}$, moet hij 'zijn ziel in lijdzaamheid bezitten of buiten de geschillenregeling om een remedie vinden'. ${ }^{115}$ Daarbij kan in eerste plaats gedacht worden aan een beroep op artikel $2: 8 \mathrm{BW}$. De rechter kan voor de normering aansluiting zoeken bij artikel 2:343. Een dergelijke anpak is eerder in een andere feitensamenstelling succesvol gebleken. ${ }^{16}$

109 Hof Amsterdan(OK) 24 februari 1994, N/ 1995, 354 (Peeters/Peetess), TWWS 1996/12 m. nt WIS.

110 Fof Ansterdam(OK) 20 november 1997. N/ 1998, 392 (Hoopmans/Hoopmans), JOR 1998, 26 nu nt. Van den lingh. Do witsprak betrof het ontstan doon twee bestunders annex andeelhouders van wen nedebestuurterhandeelhotder. Het ontslag werd door de OK als gedraging ax art. 2:343 beoor deeld, warbij zij zelfs de vaag of het ontslag techtsgeldig was irielevart achite. Overigens blikt de gerschetste casus een klassek voorbeeld voor het volgen van de $2: 343$. Evenals bij "Peeters/Peeten" en Rb Breda 6 september $1994, \mathrm{~N}$ 1996, 11 betreft het statuthe directeuren die als directem oen (riant) inkomen genieten en mat ontslgg 'in een benarde positie komen te verkeren'.

11 Hof Amsterdan(OK) 9 december 1993, NJ 1994, 296 (Wan Eyk/Nootebos ID) en Hof Anstordam(OK) I6 mart 1995, JOR 1996,54 m. nt. Wan den Ingh (Ramp/Lensen). In het laatste geval werd het concurtesende handelen van de aandeethouder, welke grond vornde voor de procedure, bowendien in strujd geacht met ant 2.8 (r.o. 5.3$)$.

112 "Peeters/Peeters" en "Hooymans/Hooymans" wergelijk respectiewelijk supranoot 109 en 110.

113 zie $\$ 2.2 .2 .2$

114. En derhalve niet in stat is overdracht van het stemrecht van de viuchtgebruiker to forceren. Zie hierand $\$ 3.4$

115 W. Westloroek, in: 'Uitkoop en geschillewegeling' (1991), p. $27-28$.

116 Pres. Rb Breda 13 mart 1998, JOR 1998, 61 (De Jong/Whchgers 1 ). Later bekrachtigd door het Hof s-Hertogenbosch 14 jamuari 1999, NJ 1999, 743 (De Jong/Wichgers II). 


\subsection{Onweming won stemrech}

Artikel 2:342 biedt aandeelhouders de magelijkheid een stemgereohtigde vruchtgebruker zijn stemrecht te ontnemen. Het artikel bevond zich aanvankelink net in het advies van de Commissie Vennootschapsrecht dat ten grondslag lag aan het wetsontwerp, maar werd toch in het ontwerp opgenonnen. De MvT concludeert dat nu vruchtgebruikers stemurecht kunnen verwerven zij de besluitvorming kunnen bemoeilijken. ${ }^{17}$ Toepassing van de geschillenregeling werd aldus ook op de stemgerechtigde vruchtgebruiker mogelijk gemaakt. Voor de hantering van deze regeling wordt verwezen naar het systeem van artikel 2:336. De vuchtgebruiker moet zich als stengerechtigde hebben misdragen en het belang van de vennootschap hebben geschaad, wil zijn stemrecht door de andere aandeelhouders kumnen worden ontnomen. In het geval de procedure van artikel $2: 342$ succes heef, valt het stemrecht terug bij de bezwarde aandeelhouder. Zowel een medeaandeethouder als de bezwaarde aandeelhouder kunnen een beroep doen op artikel $2: 342 .^{118}$

\subsubsection{De procedure}

De overdracht van aandelen op grond van de geschillenregeling geschiedt in beginsel in twee fasen. De eerste betreft de uitspraak van de rechter met betrekking tot de vordering. De uitspraak roept de rechtsgrond voor (gedwongen) overdracht in het leven, maar schept nog niet de verplichting tot levering. ${ }^{19}$ De tweede fase betreft de procedure om tot de feitelijke overdracht te komen. Daartoe wijst de rechter een (team van) deskundige(n) aan. Zij brengen een advies wit over de waarde van de aandelen op grond warvan de rechter zelfstandig een prijs bepaalt in zijn eindvonmis. ${ }^{120}$ De gedaagde is gehouden de aandelen binnen twee weken na betekening van dit vonnis aan de eiser(s) te leveren. Nergens in de wet noch in de wetgeschiedenis wordt

117 Kamersukkn W $1984-1985,18905$, nirs. $1-3$, p. 11.

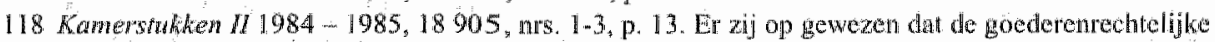

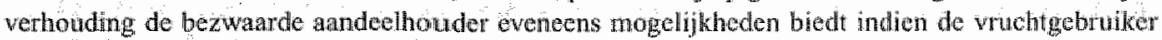
zijn bodke te buiten gat. Daabij valt we name te denken aan art 3:221. Zio over deze "zorg van

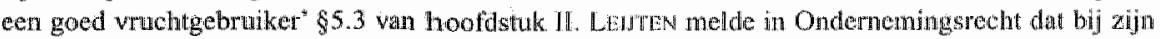
wetern nog nooi een gebruik genaakt is wan artikel 2:342. A.F.J.A. Lejien. Ondernemingsteht 199918, p. 204.

119 De gedaggde kan vanaf bet moment van een toewijzend vonmis zijn aandelen niet bezwart en slectuts met inachtname van de artikelen $2: 339 \mathrm{t} / \mathrm{m} 341$ overdragen. vergelijk hiervoor art $2: 338$. Curieus is in dit geval dal de gedagede in de uittedingsprocedure - de beoogde loper van da ahndelen van de uitredende aandeelhouder - eveneens geconfronterd wordt met een moratorim voor wat betreft de beschikkingsbevoegdheid over zjn andelen. De wetgever scheert in art. $2: 338$ de gedaagde ex art. 2.336 en de gedagede ex 2.343 onterech (en onverklaarbar) ower ecn an dezelfde Kam. Zie hierower JuA. Hamers, NW 75 (1997), p. 290-291.

120 Art. 2339 en 340 . Zie vitgebreid over de waardering van andelen in het kader wan de geschillenregeling; I. den Boer, WPNR 6487 (2002\%, p. 339 en verder. 
melding gemaakt wan het feit dat de aandelen onbezwaard dienen te werden overgedragen. HAMERS concludeert dat de overdracht van een verpand aandeel op grond van de geschillenregeling in beginsel dus leidt tot een derdenpand. ${ }^{121}$ Ook in geval van een recht wan vruchtgebruik op een aandeel leidt het beginsel van 'droit de suite' ertoe dat de aandelen worden overgedragen bezwaard met het recht van vruchtgebruik, Dit geldt zowel voor de situatie waarin de bezwaarde aandeelhouder wordt uitgestoten als de situatie waarin hij uittreedt. Anders dan bij pandrecht, waar de band tussen kredietnemer en zekerheidsnemer aldus wordt doorgesneden, is het bij vruchtgebruik niet evident onwenselijk dat het vruchtgebruik op het aandeel gevestigd blijft. Bij de totstandkoming van het recht van vruchtgebruik valt de keuze voor het vruchtgebruik op een aandeel, direct of indirect, terug te leiden naar de aard van het aandeel of de betrokken vennootschap. De persoon van de aandeelhouder lijkt van ondergeschikt belang. Dat maakt dat het "droit de suive' in gevallen van de geschillenregeling juist ziet op het behoud van de bestaansreden van het recht van vruchtgebruik, namelijk de band van de vruchtgebruiker met het aandeel en de onderliggende vennootschap.

In tegenstelling tot regeling voor overdracht van de aandelen kent de ontneming van stemrecht slechts één fase. Wanneer de rechter een toewijzend vonnis uitspreekt in het kader van artikel $2: 342$ is dit meteen het eindvonnis. Gaat dit vonnis over in kracht van gewijsde dan gaat het stemrecht van rechtswege over op de aandeelhoudende hoofdgerechtigde. ${ }^{122}$ Prijsvaststelling van het recht van stem vindt niet plaats omdat het buitengewoon moeilijk, zo niet onmogelijk wordt geacht. ${ }^{123}$

\subsection{De uitkoopregeling}

De uitkoopregeling werd in hetzelfde jaar als de geschillenregeling ontworpen en behandeld door het parlement. ${ }^{124}$ Dat de twee elkaar zo kort volgden is niet toevallig gezien de grote verwantschap die ze met elkaar vertonen.

De uitkoopregeling maakt het mogelijk voor een aandeelhouder met $95 \%$ van de aandelen om de overige aandeelhouders uit te kopen. ${ }^{125}$ De vordering van de meerderheidsaandeelhouder wordt slechts in drie limitatieve gevallen afge-wezen. ${ }^{126}$ Ten eerste wordt zij afgewezen indien de gedaagde ondanks de vergoeding ernstig stoffe-

12. Hamers, diss., p. 210. Aldaar stelt hij voor well te bepalen dat de verpande aandelen onbezwaard diem men te worden overgedragen, met daaraan gekoppeld een regel van zaaksverwanging

122 Art. 2:342 lid 3.

123 Kamerstukken II 1984-1985, 18905 , nrs. 1-3, p. 25. Aanvankelijk vermeldde de Mv"T dat het stemrecht geen vermogenswaarde had, maar op aandringen van de Raad van State werd dit geherformuleerd. Zie (Losbl.) Rechnspersonen (J.B. Huizink) art. 342- aant 2.

124 Wet van 3 maart 1988, Sib. 1988, 58 .

125 Art. $2: 92 \mathrm{a} / 201 \mathrm{a}$.

126 Art. $2: 92 \mathrm{a} / 201$ a lid 4. 
lijk nadeel zou lijden. Zij wordt ook afgewezen indien de gedaagde houder is van aandelen waaraan de statuten bijzondere rechten inzake zeggenschap hebben verbonden. Te denken valt met name aan prioriteitsaandelen. ${ }^{127}$ En ten slotte wordt de vordering afgewezen wanneer de eiser reeds afstand heeft gedaan van zijn recht tot uitkoop.

Wordt een vordering tot uitkoop toegewezen dan is de gedaagde gehouden de aandelen onbezwaard en vrij van rechten en plichten over te dragen. ${ }^{128}$ Zijn de aandelen inderdaad bezwaard dan dient de gedaagde de aandelen te consigneren. Hij deelt de hem bekende vruchtgebruiken, pandrechten en beslagen mee en door deze mededeling gaan de genoemde rechten over op het recht op de uitkering uit de consignatiekas. ${ }^{129}$ De aandelen gaan vervolgens onbezwaard over op de verkrijger. De aard van de uitkoopregeling brengt met zich mee dat ook de vruchtgebruiker aan het kortste eind trekt. De vruchtgebruiker blijft zitten met het vruchtgebruik op de prijs van de aandelen.

\subsection{De juridische fusie en splitsing}

\subsubsection{Inleiding}

De juridische fusie en splitsing vormen de meest ingrijpende wijzigingen die door een besluit van een kapitaalvennootschap teweeg kunnen worden gebracht. Het rechtsinstrument van de juridische fusie is in 1984 in onze wet geïntroduceerd ${ }^{130}$, in 1997 gevolgd door de juridische splitsing ${ }^{131}$. De juridische fusie is bij uitstek geschikt om vermogens van meerdere rechtspersonen met een 'eenvoudige' rechtshandeling in één vermogen te doen opgaan. Alle leveringshandelingen die bij een reguliere overdracht voor de verschillende activa en passiva in acht zouden moeten worden genomen, kunnen achterwege bijiven. Twee of meer rechtspersonen kunnen met gebruikmaking van één rechtshandeling het vermogen van de een onder algemene titel doen overgaan op de ander of op een nieuw daartoe op te richten rechtspersoon. Hetzelfde geldt mutatis mutandis ook voor het spiegelbeeld van de juridische fusie; de juridische splitsing. Het vermogen van rechtspersoon wordt van rechtswege en onder algemene titel verdeeld over twee of meer vermogens danwel vindt versplitsing van een deel van het vermogen plaats.

De juridische fusie en splitsing maakt het mogelijk dat de kapitaalvennootschap met een pennenstreek de rechtspositie van alle bij de vennootschap betrokken (rechts)personen ingrijpend kan wijzigen. Logischerwijs leidt dit tot een grote nadruk

127 Blijkens de wetsgeschiedenis vormt dit de prinaine reden woor inworing van deze zimsnede. Kamerstukken II 1984-1985,18904, nrs. 6 en 7 .

128 Art. $2.92 \mathrm{a} / 201$ a lid 6 .

129 Zie woor een bespreking van deze consignatie Asser/Macijer 2- HI (2000), nr. 514.

130 Wet van 19 januari 1983, Sib. 1983,59 .

131 Wet van 24 december 1997, Stb. 1997, 776 . 
op de zorgvuldigheid wan het voortraject. De belangen van de bedoelde betrokken personen dienen zoveel mogelijk te worden gewaarborgd. In de navolgende paragrafen wordt nagegaan in hoeverre de belangen van de vruchtgebruiker in acht (dienen te) worden genomen.

\subsubsection{Juridische fuste: substitutie en inzage}

Deze fusievorm werd in het kader van de derde Europese Richtlijn ${ }^{132}$ ingevoerd in ons BW. Als hoofdregel geldt dat juridische fusie enkel mogelijk is bij fusie van rechtspersonen met dezelfde rechtsworm, waarbij volledigheidshalve wordt opgemerkt dat de $\mathrm{BV}$ en de $\mathrm{NV}$ als dezelfde rechtsworm worden aangemerkt. ${ }^{133}$ De klassieke juridische fusie betreft een (nieuw op te richten ${ }^{134}$ ) verkrijgende vennootschap en (minstens) een verdwijnende vennootschap. ${ }^{135}$ Het vermogen van de verdwijnende vennootschap gaat onder algemene titel over op verkrijgende vennootschap. ${ }^{136} \mathrm{De}$ aandeelhouders van de verdwijnende vennootschap worden door de fusie aandeelhouder van de verkrijgende vennootschap. ${ }^{137}$

In het kader van vruchtgebruik alsmede pandrecht op aandelen in de verdwijnende vennootschap is een specifiek artikel toegevoegd aan de fusieregeling. Artikel 2:319 BW meldt ons dat het recht van vruchtgebruik of pandrecht op aandelen in deze vennootschap overgaat op hetgeen daarvoor in de plaats treedt. De wetgever roept ten behoeve van de vruehtgebruiker substitutie van rechtswege in het leven. ${ }^{138}$ Kont er niets voor het bezwaarde aandeel in de plaats dan is de verkrijgende vennootschap gehouden de vruchtgebruiker een gelijkwaardige vervanging te geven. ${ }^{139}$ Deze regeling ondervangt op deze manier alle mogelijke juridische fusievormen.

Naast de substitutie ex artikel 2:319 dient gewezen te worden op de publicatieplicht van de fuserende vennootschappen. Artikel 2:314 lid 2 stelt dat het bestuur van de fuserende vennootschap de stukken, met inbegrip van jaarrekeningen en nietopenbare jaarverslagen, samen met de toelichtingen van de besturen op het fusievoorstel ter inzage moet leggen voor de aandeelhouders, alsmede voor de houders

132 Richtllijn 78/855/EEG van de Raad van 20 okfober 1978, PbEG L 295.

133 De regels van fusie en splitsing hichten zich in beginsel tot aille rechtspersonen. Aangezien het rechit van vruchtgebruik op andelen onderwerp van deze dissertatie is zall ik mij beperken tot de kapitaalvenuotschappen.

134. In literatuur ook wel beeldend de "verschijnende" vennootschap genoemd. Van Schilfgarde/Winter (2003), nu. 13.1.

135 VAN SOLINGE onderscheidt zes verschillende fusiemogelijhheden in zijn dissertatie. Zie van $G$. van Solinge, diss. $V U(1994)$, p. 53.

136 Art. 2309 .

137 Art: $2: 311$.

138 Vergelijk art $3: 213$. HAMks wijst owerigens op het feit dat deze regeling haar oorsprong niét vindt in de EG-richtlijn, maar door de Nederlandse wetgever op eigen initiatief is toegevoegd. Hamers, diss., p. 184. Een en ander walt tevens af te leiden uit de vergelijking door de wetgever van de richtlijn met het Nederiandse wetsvoorstel. Kamerstukken $I I 1980-1981,16453$, nrs. 3-4, p. 28 .

139 Art. $2: 319$ lid 2. 
van een bijzonder recht ${ }^{140}$ en bewilligde certificaat-houders ${ }^{41}$ De wet noemt daarbij expliciet de houders van 'eeri recht op uithering van winst'. Hoewel de wetsgeschiedenis het vruchtgebruik op aandelen separat behandelt van de zoganaande winstbewijzen, valt niet in te zien waarom de vruchtgebruikers als winstgerechtigden van eigen soort" niet ook het recht hebben op inzage. "42 Het lot wan hun vruchtgebruik is immers eveneens bezegeld in het fusievoorstel. Hoewel de vennootschap niet verplicht is de specifieke gevolgen voor de vruchtgebruiker in thet fusievoorstel op te nemen, dient zij wel uitleg te geven over het betrokken aandeel. ${ }^{1 / 3}$ Duidelijkheid over de nieuwe rechtspositie wan de aandeelhouder levert voor de vruchtgebruiker natuurlijk direct een beeld op van zijn eigen rechtspositie. Daarnaast dient de vennootschap de statuten van de verkrijgende vemnootschap te vermelden zoals die luiden na de fusie $^{144}$ hetgeen bepalend is voor het toekennen van lidmatschapsrechten van de vrucht-gebruiker. ${ }^{145}$ Gezien het voorgaande zou ik derhalve willen betogen dat elke vruchtgebruiker een inzagerecht ten aanzien van het voorgenomen fusiebesluit dient toe te komen.

\subsubsection{Juridische splitsing: idem}

Op 1 februar 1998 trad het spiegelbeeld van de juridische fusie in werking. ${ }^{46}$ De juridische splitsing kent in beginsel twee hoofdtypen; de zuivere splitsing en de afsplitsing. ${ }^{147}$ De zuivere splitsing houdt in dat het vermogen wan een verdwijnende vennootschap onder algemene titel overgaat op twee of meer andere vennootschappen. ${ }^{48}$ Bij afsplitsing gaat (een deel van het) vermogen van een vennootschap onder algemene titel over op een of meer (verschijnende) vennootschappen. ${ }^{149}$ Aandeelhouders van de splitsende rechtspersoon worden van rechtswege aandeelhouder van de verkrijgende vennootsehap(-pen).

140 Het betreft hier een verwijzing naar art. 2320.

141 Art. 2.329.

142. De vruchtgebraiket kan evenwel indirect hetzelfde recht tor zijn beschikking helben, miss hij door de desbetreffende vennootschap met de bewilligde certificaathouder is gelijkgesteld. In dat geval kar hij eveneens aen beroep doen op art. 2329

143 Art 2.312 lid 2 sub g.

144 Art. $2: 312$ lid 2 sub b.

145 Art. 2:88/197 lid 4.

146 Wet wan 24 december 1997, $3 \$ b$. 1997, 776 .

147 Art. $2: 334$ a lid 1. Zie voor een werzicht van de werschillende mogeligke splitsingsvormen $M$. van Olffen, F.K. Buijn en PH.M. Simonis, "Splitsing van ondernemingen' (2004), p. $29-31$.

148 Art. 2:334a lid. 2.

149 Art. 2:334 a lid 3 .

150 Art. $2: 334 \mathrm{e}$ lid 1 . Hierop wordt in lid 3 een uitzonciering gevonnd door de mziesplitsing van art. $2: 334 \mathrm{cc}$ warin bepald wordt dat onderscheiden aandeehouders door de akte wan splitsing nandeelhouder worden van onderscheiden vennootschappen. Deze variant van de splitsing brengt, evenals andere varianten wan de juridhsehe splitsing, woor de vrachtgebruiker echter geen wezenlijk andere problemen. 
Evenals bij de juridische fusie wordt een speciaal artikel gewijd aan de rechten van vruchtgebruik en pand. Op gelijke voet met artikel $2: 319$ wordt op grond van artikel $2: 3340$ van rechtswege een techt van vruchtgebruik gevestigd op hetgeen de aandeellhouder voor zijn aandeel in de plaats ontvangt. Ook de verplichting van de verkrijgende vennootschap om bij achterwege blijven van vergoeding of zaaksvervanging voor vervangende waarde te zorgen is in het artikel opgenomen. ${ }^{151}$ Evenals bij de juridische fusie is naar mijn smaak een inzagerecht zoals dat voor de splitsing in artikel $2: 334 \mathrm{~h}$ lid 2 is opgenomen voor de wruchtgebruiker op zijn plaats.

\subsubsection{Behoud van Iidmaatschapsrechten bij fusie en splitsing}

\subsubsection{Inleiding}

Zoals we in de vorige paragraaf hebben kunnen zien wordt het bestaan van het recht van vruchtgebruik door middel van een wettelijk voorgeschreven substitutie gewaarborgd. Daarnaast werd betoogd dat dle niet-stemgerechtigde vruchtgebruiker toegelaten zou moeten worden tot de verplichte inzage van artikelen $2: 314$ en 2:334h lid 2 . Een ander probleem dat zich in het kader van de fusie en splitsing voordoet is de potentiële wijziging in vennootschapsrechtelijke rechten. In dit hoofdstuk is gewezen op het feit dat de statuten wan de vennootschap bepalingen kunnen bevatten die de lidmaatschapsrechten van de vruchtgebruiker kunnen beïnvloeden. Zo is het mogelijk statutair de overdracht van het stemrecht te bemoeilijken alsmede de vruchtgebruiker de certificaathouderrechten te onthouden. De regelingen omtrent de fusie en splitsing bieden echter geen garantie voor het behoud van door de vruchtgebruiker in de verdwijnende vennootschap (statutair) verkregen rechten. Het is dientengevolge mogelijk dat deze rechten in de verkrijgende vennootschap niet aan de vruchtgebruiker toekomen. In de nu volgende paragrafen zullen het mogelijke behoud van het stemrecht en de certificaathouderrechten die de vruchtgebruiker genoot in de verdwijnende vennootschap worden besproken.

\subsubsection{Juridische fusie en splitsing en het behoud van stemrecht}

Beschikt een vruchtgebruiker in de verdwijnende vennootschap over het stemrecht, dan kan zijn recht van stem in de verkrijgende vennootscllap op twee manieren bedreigd worden. Ten eerste is thet mogelijk dat de verkrijgende vennootschap de overdracht van het stemrecht heeft beperkt door middel van een blokkerings-regeling. Ten tweede is het mogelijk dat de statuten van de verkrijgende vennootschap de overdracht van het stemrecht in zoverre onmogelijk maken door de gehelle vrije kring uit te sluiten. Vooropgesteld dient te worden dat de vruchtgebruiker genoemde potentieel

151 Ant $3: 3340$ lid 2 
nadelige gevolgen kan proberen te voorkomen door tegen de fusie te stemmen ${ }^{152}$ Het hangt naturijik af van de grootte wan het pakket aandelen dat in vruchtgebruik is gegeven of een dergelijke stem doorslaggevend is. De vratg is echter of het tegen stemmen het enige alternatief is tegen het mogelijke verlies wan lidmaatschapsrechten. Op de laatste pagina's van zijp proefschrift wijd DokTMOND enige beschouwingen aan de geschetste vraagstukken. ${ }^{153}$ Voor wat betreft de aanwezigheid wan een wan toepassing zijnde blokkeringsregeling meent DORTMOND dat deze door de juridische fusie buiten werking wordt gesteld. 154

Het fusiebesluit breekt in dat opzicht het besloten karakter van de statuten wan de verkrijgende vennootschap, waardoor:

( (...) de verkrijgende vennootschap haar poorten open stelt voor de aandeelhouders van de vennovtschap die zij door fusie owerneemt, $(. .)^{*}$

Hij vervolgt:

'Indien nu bij fusie een wiltzondering wordt gemaakt op de beslotenheid, op welk beginsel de blokkeringsregel is gebaseerd, dan dient de uitzondering ook te gelden voor de op de blokkeringsregeling berustende beperking van het toekennen wan het stemrecht aan pandhouders en vruchtgebruikers, wier recht door fusie overgaat als waren zij personen, aan wie aandelen vrijelijk kumnen worden overgedragen." 155

DORTMOND concludeert dat door het nemen van het fusiebesluit de verkijgende vennootschap de stemgerechtigde vruchtgebruiker, analoog aan de owergang van het aandeelhouderschap, onwoorwaardelijk dient te accepteren. Tot een zelfde conclusie komt hij voor het tweede geval. DorTmond herhaalt de stelling dat de verkrijgende vennootschap door het fusiebesluit de stemgerechtigde vrucht-gebruiker als zodanig accepteert. Het feit dat de statuten van de verkrijgende vennootschap de vrije kring uitsluiten, doet volgens DortMond niet aan deze conclusie af. ${ }^{156}$ De sluitende bespre-

152 VAN De lNGH gat in zijn proefschrift in op de positie van hot AK bij eer dergelijk besluit. Hij conoludeert dat het AK slechts met zoveel stemmen ten gunste wan het fusiebosiluit mag stemmen als ar certificathouders zijn die daamee wooraf hebben ungestemd. Vergolijk Van den Ingh, diss; $\mathrm{p} .238$ De vergelijking met het wrichtgebruik gat in zovere mamk dat er vaak geen sprake is wan meer dan eén vruchtgebruker en dat diens belang abyjd moet worden meegenomen bij het withrengen vant stem door de andeelhouder.

153 P. Dortmond, diss. KUN (1989), p. 104 on verder.

1.54 Anders: Handboek NY/BV $(1.992)$, nr. 416.

155 Dortmond, diss. p. 106-107.

156 Dortmond, diss., p. 107. Opgemerkt dient te worden dat hij voor wat betreft de positie wan de stemgerechtigde pandhouder toteen andere conclusie komt. Zulks heeft te naken met het feit dat de toekenning van stemrecht aan de pandhouder, in tegenstelling tot het vruchtgebruik, zonder nueer statutair werboden kan worden. 
king van DokTMoND duild geen tegenspraak en ik onderschrijf deze derhalve. Ook HAMER ${ }^{157}$ en VISSER ${ }^{158}$ sloten zich aan zijn wisie.

6.6.4.3. Juridische fusie en splitsing en het behoud van certificaathoudersrechten Onbesproken blijven echter de rechten die de vruchtgebruiker zonder stemrecht kan ontvangen krachtens zijn gelijkstelling met de bewilligde certificaathouder. Evenals bij het stemrecht is het denkbaar dat de statuten van de verkirigende vennootschap het behoud van deze rechten in de weg staan: De statuten van de verkrijgende vennootschap kumen bepalen dat de vruchtgebruiker zonder stemrecht de bedoelde rechten niet heeft. In tegenstelling tot het stemrecht heeft de verkrijgende vennootschap de mogelijkheid de vruchtgebruiker deze rechten expliciet te onthouden. De vergelijking met de doorbroken blokkeringsregeling inzake het stemrecht gaat in deze dus niet op. De wruchtgebruiker zonder stemrecht die over de rechten van een bewilligd certificaathouder beschikte zal deze in de verkrijgende vennootschap niet behouden, indien de statuten niet in de toekenning van de rechten aan de genoemde vruchtgebruiker voorzien. De niet stemgerechtigde vruchtgebruiker verliest derhalve zijn rechtstreekse band met de vennootschap.

\subsection{Conclusie}

Het bijzondere karakter van de lidmaatschapsverhouding die het eigendom van een aandeel in een kapitaalvennootschap met zich mee brengt maakt dat de vruchtgebruiker in beginsel afhankelijk is van de aandeelhouder. De wetgever heeft dit benadrukt door het stemrecht in beginsel bij de aandeelhouder te laten rusten. Het stemrecht van de aandeelhouder kan echter overgedragen worden aan de vruchtgebruiker, mits de beperkende werking die van de statuten der vennootschap kan uitgaan wordt overwonnen. De wet schrijft sinds de invoering van het nieuwe erfrecht de overdracht aan de vruchtgebruiker ex artikel 4:19 en 4:21 zelfs voor. Daarmee worclt bewust uiting gegeven aan de noodzaak de vruchtgébruiker rechtstreeks te betrekken in - de besluitvorming van - de vennootschap. Deze betrokkenheid wordt echter ook langs andere wegen bereikt. Zo heeft de stemgerechtigde vruchtgebruiker van rechtswege de beschikking over de rechten van de bewilligde certificaathouder. De niet-stemgerechtigde vruchtgebruiker heeft slechts woorwaardelijk toegang tot deze rechten. Wederon spelen de statuten van de vennootschap een bepalende rol bij de toekenning van vennootschapsrechtelijke rechten. Indien de vruchtgebruiker de rechten van de bewilligd certificaathouder heeft ontvangen, of in geval van de NV hem deze niet worden onthouden, wordt de redelijkheid- en billijkheidskring van artikel 2:8 eveneens voor hern ontsloten. Dit biedt hem aanvullende rechtsinstrumenten om zijn

157 Hamers, diss, p. 186.

158 Visser, diss, par. 218 en verder. 
belangen in de vennootschap te bewaken. Met name de besluiten die in onredelijke mate inbreuk maken op zijn gerechtvaardigde belangen zijn voor vernietiging vatbuar.

Het behoud van de zojuist geschetste rechtspositie is, bij wijzigingen op grond van het vennootschapsrecht, niet zonder meer gegeven. Ten eerste kan de vruchtgebruiker op individuele basis zijn stemrecht worden ontnomen. De bezwaarde aandeelhouder kan daarenboven worden uifgestoten of kan eigener beweging uittreden. In beide gevallen ontbreekt het de wet aan aandacht voor de positie van de betrokken vruchtgebruiker met als gevolg dat teruggevallen moet worden op de regels wan het goederenrecht. De aldus ontstane situaties zijn echter veelal niet verkieselijk voor partijen en kunnen beter door proactief handelen van partijen voorkomen worden. In geval van juridische fusie en splitsing heef de wetgever wel aandacht gehad voor de positie van de beperkt gerechtigde. De geboden regeling reikt echter niet verder dan een vennootschapsrechtelijke toepassing van de substitutieregel. De lidmaatschapsrechten van de vruchtgebruiker staan ook in dit geval op de tocht. Eenmaal verworven rechten dienen echter door de verkrijgende vennootschap gerespecteerd te worden. 



\section{Hoofdstuk 7}

\section{DRIE LATERALE VERKENNINGEN}

\subsection{Inleiding}

In de voorafgaande hoofdstukken is getracht een beeld te verschaffen ten aanzien van het recht van vruchtgebruik op een aandeel in een kapitaalvennootschap. Daarbij is met name de aandacht gericht geweest op de Nederlandse rechtssystematiek en de daarbij opkomende juridische vraagstukken. Het beeld dat geschetst wordt laat zien dat het samensmelten van twee uiterst diverse juridische instrumenten naar huidig recht op de eerste plaats een kwestie van techniek is. Gaandeweg het onderzoek ontstond de behoefte het onderwerp in een breder kader te plaatsen. Niet alleen is dit dienstig aan de helderheid van de bespreking, maar eventuele voorstellen tot aanpassing en punten van kritiek kunnen tevens zorgvuldiger in ons rechtssysteem worden ingepast. De verbreding van het kader vindt plaats, zoals de titel van dit hoofdstuk reeds aangeeft, door middel van de verkenning van drie laterale deelgebieden van het recht. De keuze voor deze deelgebieden is niet alleen ingegeven door de verwantschap die zij vertonen met vruchtgebruik op aandelen, maar ook de verwantschap die zij met elkaar vertonen. De drie deelgebieden die worden vergeleken met het vruchtgebruik op aandelen geven zo nieuwe inzichten in de relaties die in het systeem van het vruchtgebruik een rol spelen.

Het eerste deelgebied dient ter nadere analyse van de relatie tussen de vruchtgebruiker en de aandeelhouder. De belangen die de aandeelhouder en de vruchtgebruiker nastreven zijn in wezen tegenstrijdig. De aandeelhouder wiens aandeel met het vruchtgebruik is bezwaard zal het behoud en, zo mogelijk, de groei van het stamkapital hoog in het vaandel hebben. De vruchtgebruiker heef, naar de aard van zijn beperkte recht, behoefte aan uitkering van het volle potenticel van de vruchten op het aandeel. De vraag die zich in dit kader aandient is of, en zo ja in welke mate, de risicoverdeling consequenties heeft voor de ondenliggende rechtsverhouding. Problemen van risicoverdeling en - economisch - belang worden reeds geadresseerd binnen het leerstuk van de economisch eigendom. Hoewel het onderwerp niet onomstreden is ${ }^{1}$, biedt de praktische wijze waarop deze vorm van eigendom ingang heeft gevonden in de rechtspraktijk een verhelderend perspectief op de rechtsrelatie tussen de vruchtgebruiker en de aandeelhouder.

1 Gewezen kan bijworbeeld worden op de discussie tussen HuLGEw en MAEdyan ten anzien van economische eigendom en het wennootsohapsrecht. Respectievelijk W. G. Huigen, WPNR 6166 (1995), p. 63 en volgende en JM.M. Maejjer, MPNR 6182 (1995), p. 337 en verder, iner een naschifi van Hurges op p. $342-344$. 
Het daaropvolgende rechtsonderwerp dat wordt aangesneden is dat van de certificering van aandelen. Op verschillende platsen in deze dissertatie ${ }^{2}$ is inmiddels gewezen op de parallellen die door de wetgever worden getrokken tussen certificering en vruclitgebruik op andelen. Reeds hierom is een specifieke bespreking gerechivaardigd. Met name dienen de wolgende vragen te worden geadresseerd. In hoeverre zijn de vruchtgebruiker en de certificaathouder over éen kam te scheren? Houdt de wettelijke gelijkschakeling ex artikel 2:88/197 lid 4 nog onverminderd stand? De driehoeksrelatie tussen de vruchtgebruiker/certificaat-houder, de vennootschap en de aandeelhouder zal in deze context worden behandeld.

Ter afsluiting wordt een kijkje genomen over de grenzen van jurisdictie en nationaliteit: De goederenrechtelijke verhouding tussen aandeelhouder en vruchtgebruiker kent in zijn huidige vorm en functie opvallende gelijkenissen met de trustverhouding in de Angelsaksische rechtssystemen. Binnen de categorie landen die een systeem van 'common law' kennen, neemt Zuid-Afrika een bijzondere plaats in. Hoewel Zuid-Afrika heden ten dage werkt met het principe van 'stare decisis', kwalificeert het rechtssysteem strikt genomen niet als common law. Het Romeins-Hollandse recht vormt in Zuid-Afrika het fundament waarop het Angelsaksische systeem als gevolg. van de kolonisatie door de Britten is gebouwd. De combinatie van rechtsinvloeden leidt ertoe dat het Zuid-Afrikaanse rechtssysteem wordt aangemerkt als een 'mixed legal system" of "gemengd rechtsstelsel'.3 De trustverhouding diende in dit land vanwege dit uitgangspunt (aanvankelijk) verklaard te worden met het aan ons huidige systeem verwante Romeins-Hollandse recht. De zoektocht naar een plaats voor de trust binnen het Romeins-Hollandse recht maakt bespreking ervan interessant. Bovendien blijft de stap naar conclusies voor het Nederlandse recht door deze gemeenschappelijke achtergrond een relatief kleine. De Zuid-Afrikaanse trustverhouding wordt in $\$ 7.4$ besproken.

\subsection{Economisch eigendom en vruchtgebruik}

\subsubsection{Inleiding}

De bespreking van economisch eigendom in een privaatrechtelijke - en meer in het bijzonder goederenrechtelijk georiënteerde - dissertatie is een enigszins precaire aangelegenheid. Het Nederlands Burgerlijk Wetboek kent immers geen regeling van economisch eigendom. Niettemin makkt de rechtspraktijk kwistig gebruik van rechtsverhoudingen die met het etiket van economisch eigendom worden beplakt. Met name in de fiscale rechtspraktijk is de constructie van economisch eigendom gemeengoed geworden. Het doel en de invulling van het leerstuk van de economisch

2. Vergelijk met namue de bespreking in $\$ 6.2 .2$.

3 Naast Zuid-Afrika behoren tot deze categorie onder meer Sehotland, Louisiana, Quebec en Mauritius. M. Lupoi, 'Thuss' (2000), p. 297; J.M. Milo en J.M. Sunits, ERPL 2000/3, p. 423-424. 
eigendom is naww verwant het die van het vruchtgebruik. Een vergahjikende bespreking is in dit kader zinvol. Allereerst wordt begonnen met een imentarisatie van wat men onder het begrip economisch eigendom verstaat. Daartoe wordit zoveel mogelijk aansluiting gezocht bij de algemene opvattingen in de literatuur. In $\$ 2.3$ wordt economisch eigendom in verband gebracht met het vruchtgebruik op aandelen.

\subsubsection{Economisch eigendom}

Alvorens tot een begripsbepaling te komen ten aanzien van economisch eigendom is het goed er op te wijzen dat het begrip "economisch eigendom" naxar Nederlands recht in beginsel niet kán bestaan. In zijn algemeenheid kent ons recht per slot van rekening geen splitsing van eigendom. Met name de goederentechtelijke implicatie dat eigendom onder te verdelen is in juridisch en economisch eigendom, wordt gelogenstraft. De rechtsbetrekkingen die naar Nederlands recht kunnen bestaan tussen een goed en een persoon zijn dwingendrechtelijk en limitatief verankerd in de door ons rechtssysteem omarmde "numerus clausus".4 In het spraakgebruik en niet in de laatste plaats de literatuur wordt niettemin de term economisch eigendon gebezigd. ${ }^{5}$ In vervolg zal deze term worden gehanteerd met dien verstande dat daaronder moet worden verstaan "in economisch zin gerechtigd zijn"."

Nu een regeling en dus een definitic van economisch eigendom ontbreekt in ons Burgerlijk Wetboek dient men zich voor de privaatrechtelijke invulling ervan te wenden tot de literatuin.

Allereerst duidt SLAGTER de economisch eigendom aan als een verzamelnaam van:

'(...) een aantal rechtsfiguren, die als gemeenschappelijk kenmerk hebben, dat de juridische eigendom berust bij een ander, dan degene bij wie het economisch belang berust." T

De verklaring voor het gebruik als verzamelnaam is thet feit dat economisch eigendom in de praktijk in verschillende vormen voorkornt, waarbij elke vorm een bepaald

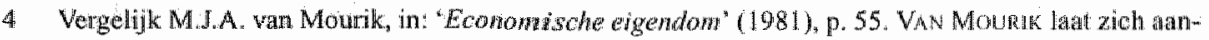
shitend (zie p. 5\%) kritisch nit over SLAGrER's idee dat het economisch eigendom ech rech op de warde vam een object dar is afgesplitst van het redit op het object (W. Slagter, "Nhridische en economische algendom" (1968), $\mathrm{p}, 42-43)$.

5 Vergehijk bijvoorbeeld D. wam Dijk, "De economische eigendom is geer eigendom", Hef Financiecle Dagblad 15 november 2004

6 Tie tevens A.A. van Velten, diss. Wva (1982), p. 8485; WG. Hingen, "Liconowische aigendow" $(1995)$, p. 13. In aansluiting hierop zal ik telkens sprekel van "economisch eigenaar" hoewel deze

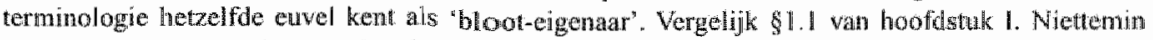
lijkt het mij in dit geval het wasthouden aan 'eigenaar' in dit geval, gezien de onafscheidelikheid van de twee termen, gerechtvaratigd.

7 W. Slagter", in:" "Quod Licet" (1992), p. 367. 
doel dient. Vanuit dit oogpunt is het praktischer nadruk te leggen op wat deze verschillende rechtsverhoudingen met elkar verbindt. Opvallend daarbij is dat de grootste gemene deler van deze rechtswerhoudingen een negatief aspect is. Economisch eigendom is niét juridisch eigendom. Zoals hierboven vermeld, kent de fiscale rechtspraktijk in tegenstelling tot haar privaatrechtelijke evenkmie een zeer belangrijke nol toe aan de economisch eigendom. HUUOEN sluit woor wat betreft de omschrijving van de economisch eigendom aan bij de jurisprudentie wit het belastingrecht. Zijn definithe huid:

'Het krachtens een (obligatoire) rechtsverhouding gerechtigd zijn tot in beginsel alle rechten ten aanzien van een goed en gehouden zijn alle verplichtingen ten aanzien vall dat goed te dragen en daarmee het volledige risico wan wardeverandering casu quo tenietgaan van het goed voor zijn rekening te nemen, zonder dat het goed in juridische zin geleverd is."

De verschillende elementen kunnen als volgt worden uitgelicht. Vooreerst ligt de nadruk bij de economische eigendom op een obligatoire rechtswerhouding. Partijen sluiten een of meer wederkerige overeenkomsten ten aanzien van een bepaald goed: Het doel dat zij daarmee wensen te bereiken vormt het tweede element van economisch eigendom. Getracht wordt door middel van de obligatoire rechtsverhouding een ander dan de juridisch eigenaar zoveel mogelijk de bevoegdheden van een juridisch eigenaar te doen toekomen alsmede hem de waardevermeerdering ter beschikking te stellen. Tezamen vormen zij het belang dat de economisch eigenaar bij het goed heeft; hij is economisch belanghebbende als ware hij eigenaar. ${ }^{10}$ De keerzijde van de medaille wordt gevormd door de wijziging van de risicosfeer. Met het ontvangen van de economische gerechtigdheid komt het goed voor rekening en risico van de economisch gerechtigde. Het belang van de economisch eigenaar duidt mitsdien ook op de verplichtingen van de economisch eigenaar.

De zojuist geschetste functie en doei van de economisiche eigendornsconstructie moet echter voorzien worden van enige kritische noten. Niet nagelaten mag worden (nogmaals) te benadrukken dat de constructie valt of staat met haar obligatoire fundament. De "numerus clausus' voorkomt dat de toedeling van economisch eigendom dit obligatoire karakter ontstijgt." De beperking tot het obligatoire karakter houdt voorts

8. G. E. var Mannen, 'Eigendomsschimbewegingen' (1987), p. 13; Pitlo/Reehuis-Heisterkamp (2001), n. 469 alsook SLAGrek die de economische oigenaar verder kwalliceert als psevdo-eigenaar". Slagter, in 'Quod Licet' (1992), p. 366. Deze kwalifucatie kom muj echter in het knder van de bespreking van de economisehe ejgendom niet alls bijzonder verhelderend voor. Ik zall harar derhalve niet overnemen.

9 W.G. Huijgen, "Economische eigendom" (1995), p. 12.

10 M.A. van Mourik, in: "Economisehe elgendom" (1981), p. 57.

11 Hier past evenwel de opmerking de het dwingende karakter van de "munerus' clausus" de lagtste tijd narar de mening wan sommigen als te beklemmend wordt ervaren. 
in dat het goederenrechtelijk systeem en bijwoorbeeld de regels van overdracht niet toepasbaar zijn op economisch eigendom ${ }^{12}$, eenvoudigweg omdat het geen zel/standig subject van recht vormt. ${ }^{13}$ De economisch eigenaar kan met name geen beroep doen op een eventuele goederenrechtelijke werking van de constructie. Naar inijn mening is een strikte redenering in liet geval van faillissement - door Nievwentus zo fraai omschreven als 'de grote lakmoesproef van het goederenrecht"' - de enige juiste weg. ${ }^{15}$ De economisch eigenaar dient ten strijde te trekken met zijn obligatoire bewapening, hooguit in bepaalde gevallen versterkt door een zekere derdenwerking ten aanzien van elementen van de overeenkomst(en). ${ }^{16}$

\subsubsection{Elementen van economische eigendom en vruchrgebruik}

De schets van economisch eigendom maakt duidelijk dat niet zozeer sprake is van cen op zichzelf staand juridisch fenomeen als wel van een categorie rechtsverhoudingen met een of meer gemeenschappelijke eigenschappen. De belangtijkste eigenschap is, in algemene termen, de scheiding tussen belang en juridisch eigendom. ${ }^{17} \mathrm{De}$ rechtsverhouding die gecategoriseerd kan worden als economisch eigendom kenmerkt zich doordat de juridisch eigenaar niet langer - uitsluitend - belang heeft bij het goed. Het samenvoegen van de verschillende rechtsverhoudingen maakt dat tot op zekere hoogte het motief van de genoemde scheiding van ondergeschilkt belang is. Een belangrijk motief is evenwel in veel gevallen de rechtsgevolgen wan juridisch eigendom buiten de deur te houden. Exemplarisch is in dit geval de casus van "Modehuis Nolly"18, waarin de vrouw uit goederenrechtelijke overwegingen onroerend goed op naam van haar man had laten zetten. Daarmee beoogde zij expliciet te

12 W.G. Huijgen, $a . w$, p. 13 .

13 J.H. Beekhuis, in: 'Ronse-bundel' (1986), p. 586.

14 Zie onder meer J.H. Nieuwenhuis, "Uit de baw wan hier en mu" (1980), p. 22.

15. Anders Schoordijk die de economisch eigenaas (in het huwelijksgoederenrecht) bescherming toemdicht door middel van de vertegenwoordigingsconstructic. H.C.F. Sehoordijk, in: "Economische" eigendom' (1981), p. 6. VAN VELTEN wratget zich in dezelfde bundel - mijns inziens terecht - af of deze constructie niet erg gekunsteld voorkomt (A.A. van Velten, in: "Economische eigendom" (1981), p. 28). Vragen die ook Van Mourik - vergeefs - in de aansluitende fortundiscussie stelt ( $a$.w. p. 82-83). Ook BeEkHUls sluit zich later bij de afwijzing van deze constructie atan. J.H. Beekhuis, in: 'Ronse-buindel' (1986), p. 592.

16 Bijwoorbeeld ex art. 3:298. Zie Snijders-Rank-Berenschot (2001), nr. 204. Van der Grinten heeft in het verleden gesteld dat hij van mening is dat cen schuldeiser onbehoorlijk zou handelen wanneer hij verhaal haalt op economisch eigendom (W.C.L. wan der Grinten en W.C. Treurniet, "Certificering van onroerend goed" (1964), p. 35 en "79.

17 Hieruit blijkt overigens ook de verwantschap met de fiduciaire rechtsverhouding. RankBERENSCHOT kwalificeert de juridische eigenaar in een economische eigendomconstructie als de "fiduciair" eigenaar. Snijders-Rank-Berensichot (2001), mr. 204.

18 HR 2 april 1976, NJ 1976, 450 m.nt. WMK (Nodehwis Nolly). Het arrest kwam in werband met de leer wan de directe verkrijging reeds an bod. Zie $\$ 6.3$ van thoofdstuk II. 
voorkomen dat het goed in haar vermogen zou vallen en in geval van haar faillissement of het fallissement van haar onderneming zou worden uitgewonnen. ${ }^{19}$

In welke mate is de constructie van economisch eigendom nu van belang voor het vruchtgebruik op aandelen? De reden voor het bespreken van de economisch eigendom is gelegen in het feit dat deze constructie de verhouding tussen belang, risico en eigendom wijzigt. De constructie is zoals gezegd op verbintenisrechtelijke leest gesehoeid. Naar mijn smaak komt niettemin het vruchtgebruik van goederen en het vruchtgebruik van aandelen in het bijzonder in aanmerking om met economisch eigendom te worden vergeleken. Ook in het vruchtgebruik wordt het economisch belang en - gedeeltelijk - het risico gescheiden van de juridische eigendom. In het algemeen dient het behouden van de hoofdgerechtigdheid een specifiek doel. De juridische eigendom moet bij de hoofdgerechtigde blijven. In het bijzonder dient in dit kader gewezen te worden op de keuze voor het vruchtgebruik in het nieuwe erfrecht. Het vruchtgebruik wordt hier als juridisch instrument ingezet om de langstlevende met de economisch aspecten wan een goed te begunstigen ten behoeven van diens verzorging. De juridische eigendom blijft in de vorm van de hoofdgerechtigdheid bij de erfgenamen ${ }^{20}$ Daarnaast heeft de vruchtgebruiker van aandelen belang bij de waarde van de aandelen.

Goederenrechtelijk gezien maakt de vruchtgebruiker aanspraak op het economisch aspect van een aandeel in de vorm wan dividenduitkeringen. Bovendien draagt de vruchtgebruiker voor zover hij beschikkingsbevoegd is de zorg voor de aandelen. ${ }^{21}$ Uit deze zorgplicht kan zelfs aansprakelijkheid voortvloeien. ${ }^{22}$ Wat echter verwondering wekt is dat, in tegenstelling tot de laatst genoemde last (mogelijke aansprakelijkheid), de met economisch eigendom vergelijkbare lust (waarde-vermeerdering van de aandelen) de vruchtgebruiker niét toekornt. Deze onevenwichtigheid is het meest sprekend bij beursgenoteerde aandelen. De vruchtgebruiker is op grond van de algemene regels van vruchtgebruik naar de aard van het goed beschikkingsbevoegd. ${ }^{23}$ Naar heersende jurisprudentie is de vruchtgebruiker gehouden fatsoenlijk beheer te voeren over de aandelen. ${ }^{24}$ De eventuele waardevermeerdering door dit beheer komt de vruchtgebruiker naar huidig recht en staande jurisprudentie niet toe. ${ }^{25} \mathrm{Naar}$ mijn

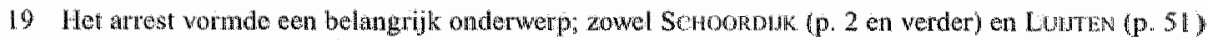

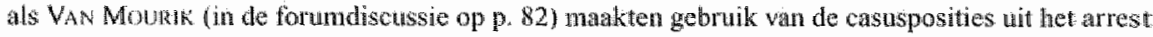
om hun respectieve standpunten uited te zetten. Allen in 'Ecowomnich elgendown', Ars Notariatus $X X 11081)$

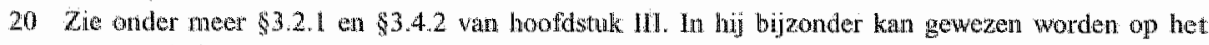
zelerhwidselement dat wordt aangekart bij het creèren van de wilsrechten woon de kinderen. Vergelijk in thet bijzonder \$3.4.2.

21 Vorgelijk hiervoor mijn bespreking wan het recht van boheer en beschikking in $\$ 5.52 .35 .52$.

22 HR 9 guruari 1998, NJ 1999, 285 mun. WMK (MesPejson/Ten Bos).

23 Vergeligk murjo conclusie in $\$ 5.2$ en $\$ 5.3$.

24 Wederom zij verwezen naar het arrest "MeesPierson/Ten Bos". Vergellik noot 22 supra:

25210 \$ 5.5 .1 
smaak kan dit gebrek in balans worden hersteld door ansluting to zoeken bij de systenatiek van economische eigendom. De vruchtgebruker dient verbintensrechtelijk aanspraak te kunnen maken op de meerwaarde van woor vethandeling bestemde andelen. ${ }^{26}$ Vooralsnog is een rechtstreekse en dwingende goederenrechtehike aarspraak mijn inziens geen haalbare kart. Het zou te verkiezen zijn wanneer een dergelik beding standaard deel gaat ütmaken wan de vestiging van vruchtgebruik. Zulks zou bovendien op den duur een positief neveneffect hebben. Als gevolg van 'bestendige bedingen in de praktijk" kan op voet van het arrest "Radio Holland" 27 de waardeven"meerdering zodoende op grond van de verkeersopvatting deel gaan uitmaken van de goederentechtelijke vrucht.

\subsection{Certificering en vruchtgebruik}

\subsubsection{Inleiding}

In $\$ 6.2 .2$ is reeds gewezen op de vrij achteloze wijze waarop de wetgever de vruchtgebruker de rechten van de bewilligd certificaathouder heeft toegekend. Een goed spreekwoord leert dat men een gegeven paard niet in de bek kijkt, maar een vorsende blik is hier op zijn plaats. Is deze gelijkschakeling nog gerechtvaardigd of heeft $z \mathrm{j}$ haar houdbaarheidsdatum overschreden?

Ongehkkigerwijs schort het in de wetsgeschiedenis aan een diepgravende analyse ontrent de genoende gelijkschakeling. ${ }^{28}$ Ook in de literatuur ${ }^{29}$ zijn de plaatsen waar deze gelijkschakeling wordt gemotiveerd schaars. Helaas blijkit dit een gemis nu juist deze gelijkschakeling voor problemen zorgt bij behandeling van de positie van certificaathouders. ${ }^{30}$ Hierna bespreek ik eerst in hoofdlijnen de certificering van aandelen. In de daaropvolgende paragrafen volgt een nadere anallyse van de certificering.

26 Mogelijkerwig kan angesloten worden bij do fischle paktijk warbij de fiscus uitgat wain ten fic-

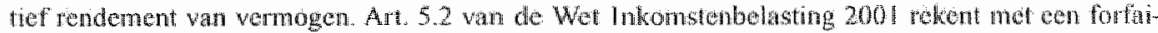

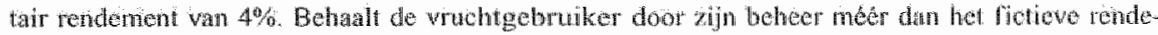

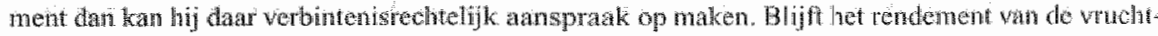
gebruker onder het fictiewe zal hij moeten antonen dat zulks gesu droct gevolg is wan hot door loem gevoerde befoer.

27 HR 16 mart 1979, NJ 1980,600 m.nt. BW (Radio Hollowd. Zie voon de bespraking ervarn 2.4 . I

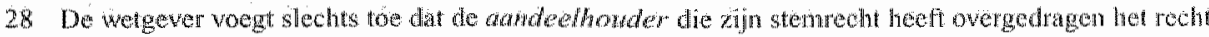

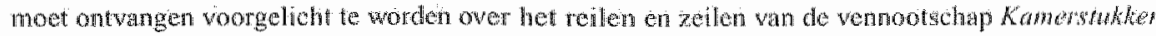
I1973-1974, 12 897, nt, 3, p. 5 .

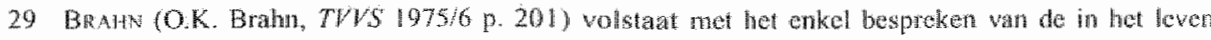

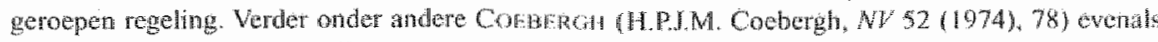
meest recentelijk Asser/Maeiger 2-In (2000), nu. 224

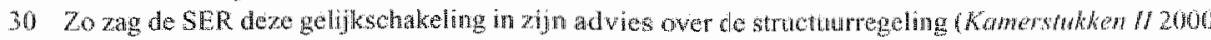

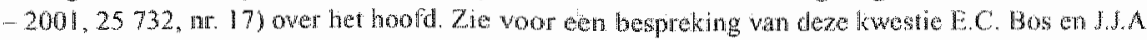

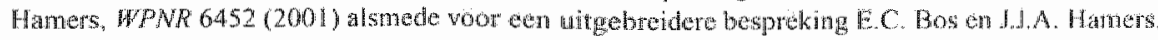
Sinching of Wenging $2001 / 5$. 
Deze analyse modelleer ik naar de werkwijze van VAM DEN INGH in zijn proefschrift over certificering. ${ }^{3 !}$ VAN DEN INGH ontwaart in zijn dissertatie drie rechtsverhoudingen ingeval van certificering. Ten eerste die tussen de certificaathouder en de aandeelhouder, ten tweede de relatie tussen de aandeel-houder en de vennootschap en tot slot de rechtsverhouding tussen de certificaathouder en de vennootschap. Deze drie rechtsverhoudingen zijn ook bij het recht van vruchtgebruik op een aandeel waar te nemen. De analogie kan op verschillende aspecten worden getoetst. Deze verhoudingen en de relatie met de vergelijkbare rechtsverhoudingen ingeval van certificering zullen hier de revue passeren.

\subsubsection{Certificering van aandelen ${ }^{32}$ : een korte introductie}

Certificering van aandelen creëert een scheiding tussen het vermogensaspect en het zeggenschapsaspect. De aandeelhouder houdt aandelen ten titel van beheer en geeft certificaten uit die enkel recht geven op de economische waarde van het aandeel. ${ }^{3.3}$ Aanvankelijk was de certificering van aandelen uit nood geboren. Het diende als instrument om Amerikaanse aandelen op naam met een hoge nominale waarde gemakkelijker verhandelbaar te maken. ${ }^{34}$ In de loop der jaren is de certificering echter uitgegroeid tot een juridisch instrument met een veelzijdig karakter. Naast het initiële motief van de verbetering van de verhandelbaarheid van aandelen kunnen thans nog worden genoemd het creëren van oligarchische verhoudingen, het bestrijden van aandeelhoudersabsentie bij beursvennootschappen, het beschermen van de vennootschap tegen vijandelijke overnamepogingen en ten slotte het voorkomen van versnippering van het aandelenkapitaal als gevolg van het erfrecht. ${ }^{35}$ De ontwikkeling van het juridische kader rond de certificering van aandelen vertoont een typische verloop. In de tijd dat de verhandelbaarheid van buitenlandse aandelen het belangrijkste motief vormde voor certificering bekommerde de Nederlandse wetgever zich niet om

31 F.J.P. van den Ingh, 'Cervificering en cervificaat wan aandeel bij de bestoten venmoatschap', dissertatie KON $(1991)$.

32 Cortificering is overigens niet voorbehouden aan aandelen. Vergelijk over certificering wan onroerend goed reeds W.C.L. wan der Grinten en W.C. Treurniet, "Certificering wan onroesend goed" $(1964)$.

33 F.J.P. van den Ingh, diss. KUN (1991), p. 16 daarbij gebruik maken van cen citaat uit C. AE. Uniken Venenta en S.E. Eisma, "Eigendon ten tikel van beheer nad komend rech" (1990), p. 86-87. In deze zin wordt de constructie enerzijds geschard onder de moemer van de "fiduciaire rechtsverhoudingen' (meer in het bijzonder de fiducia cum anico, Asser/Maejer 2-III (2000), nr. 403) anderzijds. behoort zij tot de zojuist besproken constructie van economisch eigendon. Vergelijk W.I. Slagter, 'Atwridisehe en ecomonische eigendom' (1968), p. 48; M.J.A. van Mourik, in: 'Economische eigendow" (1981), p. 61 en verder; R.P. Voogd, diss. KUN (1989), p. 23; Fu.P. van den Ingh, diss. KUN (1991), p. 171; W.G. Hujigen, 'Econonische eigendom' (1995), p. 89 en verder. Deze conclusie versterkt naar mijn smaak werder de verwantschap tossen certificering en vruchtgebruik.

34 Voogd, diss., p. 21; Van den Ingh, diss, p. 28.

$35 \mathrm{C}$. 2 . Uniken Venema en S.E. Eisma, 'Eigendon ten fitel wam beheer naar komend recht' $(1990)$, p. 59-60; Asser/Maeijer 2-1II (2000), nr. 403. 
de wettelijke positie van de certificaathouder. In 1971 komt daar echter verandering in met de invoering van de Structururwet ${ }^{36}$ Ondanks het feit dat certificering nog relatief impopulair bleek, achtte de Commoissie Verdam het destijds wenselijk een reclitsband te scheppen tussen de $\mathrm{NV}^{37}$ en de houders van certificaten van aandelen, ${ }^{38}$ In de jaren tachtig en negentig van de vorige eeuw trad de certificering als beschermingsconstructie in beursgenoteerde vennootschappen nadrukkelijk op de voorgrond. Mede als gevolg van deze trend werd de positie van de certificaathouder als kapitalverschaffer bij de herijking van de structumregeling door de SER onder de loep genomen. ${ }^{39}$ Het rapport van de SER heeft uiteindelijk geleid tot de recentelijke versterking van de positie van de bewilligd certificathouder. ${ }^{40}$

\subsubsection{De rechtsverhouding met de acndeelhouder}

\subsubsection{Certificaathouder en aandeelhouder}

Bij certificering van aandelen wordt meestal gebruik gemaakt wan een rechtspersoon - de meest gekozen vorm is de stichting ${ }^{41}$ - die de aandelen houdt ten titel van beheer $^{42}$ en als zodanig de aandeelhouderspositie bekleedt. De certificaten van de aandelen worden verkocht ${ }^{43}$ en de koper ontwangt een recht op (een deel van) de economische waarde van een aandeel jegens de aandeelhouder.4 De bron van de rechtsverhouding tussen de certificaathouder en dexe zogenaamde stichting Administratie-

36 Wet van 6 mei 1971, Stb. 1971, 289. De rechten worden toegekend aan de "bewilligd' certificaathouder. Dit houdt in dat de certificaten met medewerking van de vennootschap dienen te zijn uitgegeven. Zie over het criterium "bewilliging" $\$ 5.2 .2$.

37 De lezer zij eraan herinnerd dat de BV pas in 1971 het levenslicht zag.

38 Van den Ingh, diss., p. 8. Opmerkelijk is wederom de verwantschap met de vrtichtgebruiker. Evenals bij de vruchtgebruiker klinkt hier enkel de 'de wens' tot toekenning van vennootschappelijke rechten als grond voor een op te nemen wettelijke regeling.

39 Reeds besproken in $\$ 5.2$.

40 Wet van 9 juli $2004,5 t b .2004$, nr. 370 . De meest in het oog springende versterking betreft ongetwijfeld de privatiewe volmach die de certificaathouder op grond wan art. 2:118a lid 1 wan de Stichting AK kan verlangen. Zie voor de gewijzigde positie van de certificaathouder en certificering ais beschermingsconstructie C.A. Schwarz, ThOB 2004/5, p. 220 en werder.

41 Voogd, diss. , p. 22. Van den lingh, diss, p. 196; Handboek NV/BV (1992), nr. 197. Asser/Maeijer 2III $(2000), \pi \mathrm{nr} .405$.

42 De rechtsverhouding wordt zoals vermeld geduid als een fidueia cum amico (zie supra noot 33). De kwalificering als fiduciaire verhouding leidt ertoe dat de certificering op zijn beurt vaak betrokken wordt bij de bespreking van de trustverihoudingen en Nederlands recht. Vergelijk bijwoorbeeld Snijders-Rank-Berenschot (2001), nr. 202.

43 In deze bespreking ga ik wit van de constructice van certificering tegen contanten. De nuance dat certificering tevens tegen aandelen kan geschieden laat ik hier uit oogpunt van de helderheid van de bespreking verder buiten beschouwing.

44 Dewelke bestaat uit op de gecentificeerde aandelen gedane uitkeringen; winst, reserves enzovoort, matr ook de waarde wan het certificaat buj wervreemding. C. E. Uniken Venema en S.E. Eisma, 'Eigendom ten titel wan beheer naar komend' recht' (1990), p. 50-51. 
kantoor ${ }^{45}$ wordt gevormd door een beheersovereenkomst. In deze beheersovereenkomst die overwegend aangeduid wordt als 'de administratievoorwaarden" wordt de verhouding tussen de stichting AK en de certificaathouder ingevuld. ${ }^{\ddagger 6}$ Deze obligatoire verhouding wordt daarenboven ondersteund door een wettelijk pandrecht ten bate van de certificathouder. ${ }^{47}$ De statuten van de stichting $A K$ of de administratiewoorwarden bieden doorgaans de norm die de stichting in acht moet nemen bij de uitoefeming van het stemrecht. De stichting kan bijwoorbeeld gehouden zijn ten alle tijde de continuinteit van de vennootsehap te warborgen. Deze norm, welke vaak wordt ingegeven door het fiduciaire karakter van de certificering ${ }^{48}$, heeft betrekking op het belang van de certificaathouders. ${ }^{49}$

\subsubsection{Vruchtgebruiker en aandeelhouder}

De relatie tussen de vruchtgebruiker en de aandeehouder kent in tegenstelling tot de certificering een goederenrechtelijke oorsprong. Ondanks het feit dat een obligatoire titel benodigd is voor de vestiging en verbintenissen van obligatoire aard deel uit kunnen maken van déze vestiging ${ }^{30}$ behoort het vruchtgebruik duidelijk tot de goederenrechtelijke bloedgroep. De goederenrechtelijke verhouding betekent tevens dat doorgaans geen specifieke afspraken zullen worden gemaakt ten aanzien wan het uitoefenen van het stemreeht door de aandeethouder of in voorkomende gevallen de vruchtgebruiker. Een norm zoals deze bestaat in het kader van de certfficering ontbreekt veelal. Niettemin zou ik willen aannemen dat een dergelijke norm ook dient te gelden tussen de vruchtgebruiker en zijn aandeelhouder. Vanuit het oogpunt van de vruchtgebraiker heeft de redelijkheids- en billijkheidsnorm reeds zijn beslag in deze relatie gekregen. Artikel 3:207 lid 3 verplicht de vruchtgebruiker zich als "een goed vruchtgebruiker" te gedragen. ${ }^{51}$ Voor de bezwaarde aandeelhouder ontbreekt in het goederenrecht een dergelijke specifieke norm. Het ontbreken van een dergelijke norm valt te verklaren uit de aard van het vruchtgebruik. Zodra het vruchtgebruik is gevestigd en de vruchtgebruiker de beschikking over het goed heeft is de invloed van de hoofdgerechtigde gezien de bevoegdheden van de vruchtgebruiker doorgaans uiternate marginaal. Zulks lijdt echter uitzondering in het kader van aandelen. Indien de aandeelhouder stemgerechtigd is op de aandelen heeft hij wezenlijk invloed op de

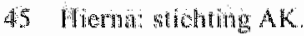

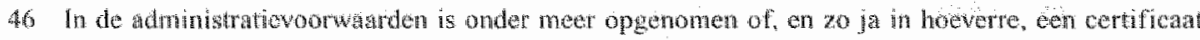

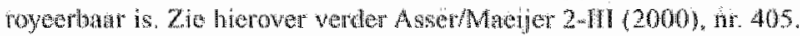

47 Art: 3259

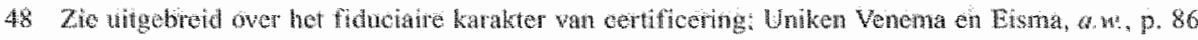
en volgende.

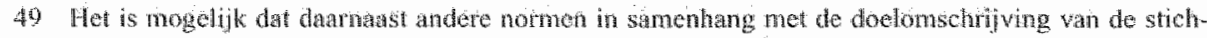
thig worden opgenomen. Met mane in het geval war do certificering dient ter besolyerming wah de betrokken vennootschap kan het bejarg yan de contintiteit wan de vennootschap als nom worden gesteld. Asser/watijer 2 m (2000), nr. 407 .

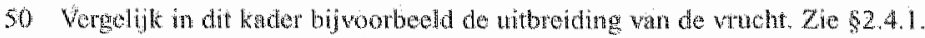

51 Vergelitk 82.5 .1 
rechtspositie van de vruchtgebruiker en kan hij diens belang - in onredelike mate schade toebrengen. ${ }^{52}$ De wetgever is zich bewust geweest van deze situatie. Hij plaatste een opmerking in dit kader bij het miet tockennen van het stemrecht an de vruchtgebruiker in het geval van een verzorgingswuchtgebruik. De wetgever stelde dat in dat geval bet uitoefenen van het stemrecht door de aandeelhouder geen afbreuk mag doen aan het belang van de vruchtgebruker. ${ }^{53}$ Weliswaar biedt het vennootschapsrecht een norm die op de stemuitoefening van toepassing is in de vorm van artikel 2:8, maar deze norm voldoet in dit kader niet. Artikel 2:8 is immers slechts in bepaalde gevallen voor de vruchtgebruiker intoepbaar. ${ }^{54}$ Naar mijn smaak moet deze norm overigens ook niet uitgaan van het vennootschapsrecht. De bron voot een der gelijke norm is immers de rechts-verhouding tussen de vruchtgebruiker en de hoofdgerechtigde: Derhalve is het deze rechtsverhouding die de hoofdgerechtigde mijns inziens verplicht tot de zorg van 'een goed hoofdgerechtigde'. Deze zorg krijgt vervolgens zijn uitwerking bij het uitoefenen van het stemrecht door de hoofdgerechtigde. De bezwaarde aandeel-houder is, naast dat hij in zijn eigen belang mag stemmen, gehouden bij stemuitoefening het belang van de vruchtgebruiker te laten meewegen. ${ }^{55} \mathrm{Ik}$ zou menen dat in het kader van het winstbesluit het belang van de vruchtgebruiker zelfs doorslaggevend moet zijn.

\subsubsection{De rechtsverhouding aandeelhouder - vennoolschap}

De aandeelhouder die zijn aandeel heeft bezwaard met een recht van vruchtgebruik behoudt in beginsel zijn stemrecht. ${ }^{56}$ Ook in het geval van certificering ${ }^{57}$ is het de stichting AK die als aandeelhouder over het stemrecht beschikt. ${ }^{58}$ In het voongaande is reeds aangestipt dat de stichting $\mathrm{AK}$ bij uitoefening van het stemrecht gebonden is aan de norm die is neergelegd in de statuten van de stichting of de administratievoorwaarden.

52 Vergelijk bjwoorbeeld het whstbestemmingsbesuit on de wucht wan cen andeel. Zie \$6.2.3.

53 Kowmershker II $1999-2000,27245$, ar. 3, p. 4. Vergotijk 8.2 .3 .

$54210 \$ 6.23$.

55 Hier treedt overigens een fundanenteel verschil net de certificering op ate voory rond. De stichting AK kath - en moet in veel gevallen - bij hatar stemuitog fening het betring van de certificauthouders en of (bijvoorbeald) het belang wan de vetunootschap behartigen. De stichting $A K$ is niet gerechtiget, in tegenstelling tot de bezwarde andeelnouder, in har ergen belang te stemmen.

56 Er zij an herinend dat stennechtowerdracht aan de wruchtgebruiker dwingend wordt voorgeschreven indien de vruchtgebruker op grond van artikel $4: 19$ of 21 het ruchtgebraik heeft ontwangen. Zie woor de bespreking $\$ 6.23$.

57 De lezer zij er an therinnerd dat voor deze bespreking uhgegan wordt van de certificering tegen contarutien.

58. Evenals bij het vruchtgebruiksystem is ingewal van certificering de athdeelhouder stengerechtigd, tenrij de economisch gerechtigde anspraak maakt op het stemecht. Het notiw ingevoerde snt. 2. 118 a biedt deze mogelijkheid aan de certificathouder. 
In de situatie van het vruchtgebruik kan de bezwaarde aandeelhouder zijn stemrecht naar huidig recht geheel naar eigen inzicht en belang uitoefenen. In de voorgaande paragraaf heb ik reeds betoogd dat de rechtsverhouding tussen de vruchtgebruiker en de aandeelhouder deze vrijheid voor de bezwaarde aandeelhouder beperkt.

\subsubsection{De rechtsverhouding wet de vennootschap}

\subsubsection{Certificaathouder en vennootschap}

Zoals eerder aangegeven ${ }^{59}$, was het de wens van de wetgever dat de bewilligd certificaathouder over bepaalde vennootschapsrechtelijke rechten kwam te beschikken. Hiermee creëerde de wetgever een rechtstreekse juridische band met de betrokken vennootschap. Het eigendom van het certificaat werd zodoende de bron wan een eigen organisatierecht. In zekere zin is deze toekenning oneigenlijk. Juridisch gezien is het de taak van de aandeelhouder van de gecertificeerde aandelen om de belangen van de certificaathouder in de vennootschap te behartigen. De certificering bood in beginsel slechts een bron van verbintenissen tussen de certificaathouder en de stichting AK. De motivering werd bij de versterking van de vennootschapsrechtelijke positie van de certificaathouder, in 2004, alsnog onderbouwd. De certificaathouder betaalt voor zijn certificaat en uit dien hoofde dient hij, als verschaffer van risicodragend kapitaal, aanspraak te kunnen maken op de corresponderende zeggensmacht: ${ }^{60}$

\subsubsection{Vruchtgebruiker en vennootschap}

In tegenstelling tot de certificaathouder verkrijgt de vruchtgebruiker zijn vruchtgebruik doorgaans om niet. Het is op dit punt dat woor wat betreft de vergelijking met de certificaathouder de schoen danig wringt. Op het eerste gezicht gaapt er een gat tussen de wijze van verkrijging door vruchtgebruiker en certificaathouder. De laatste betaalt voor zijn certificaat, hetzij in contanten hetzij in aandelen. De vruchtgebruiker daarentegen veelal niet. Met name in het geval van een erfrechtelijke verkrijging is slechts sprake van een toedeling en niet van enige inbreng door de vruchtgebruiker. ${ }^{61}$ Dit is in zoverre crucial dat de recentelijke versterking van de rechtspositie van de certificaathouder is gebaseerd op zijn rol als 'werschaffer van risicodragend kapitaal'. Aangenomen kan worden dat de rechten waarover de certificaathouder voor deze versterking reeds beschikte een vergelijkbare achtergrond kennen. Op het eerste gezicht lijkt de vruchtgebruiker geen aanspraak te kunnen maken op de titel 'verschaffer van risicodragend kapitaal'. Bij dit laatste moet echter wel een kanttekening worden geplaatst. Hoewel de vruchtgebruiker zijn vruchtgebruik niet in de klassieke zin finan-

59 Vergelijk $\$ 7.3 .2$

60 Onder andere de rechten uit artikel 2:11:4a/224a en 2:1 18a. Vergelijk $\$ 6.2 .2$.

61 Uitzondering wordt in dit geval naturijik gevormd door het legaat tegen inbreng. Verdedigd zou kunnen worden dat de vruchtgebruiker in dat geval het vruchtgebruik well orm baat verkrijgt. 
ciert, loopt hij naar mijn smaak niettemin risico. Bovendien laat het arrest 'De Visser/Harms" zien dat het door middel van een recht van vruchtgebruik verzorgd achterlaten van de langstlevende wel degelijk de voldoening van een (natuurlijke) verbintenis inhoudt. ${ }^{62}$ Daarenboven is de functie die de twee rechtsinstrumenten vervillen vanuit het gezichtspunt van de verkrijger in hoge mate vergelijkbaar. Beide hebben belang bij de uitkeringen die op het aandeel worden gedaan. Voor de vruchtgebruiker is het punt van risico zelfs pregnanter mu hij naar huidig recht geen aanspraak kan maken op de waardervermeerdering van het aandeel ${ }^{63}$, maar wel aansprakelijk kan worden gehouden voor verwijtbaar waardewerlies. De vraag kan gesteld worden of het betalen voor het desbetreffende recht vereist is voor toegang tot de geschetste rechtspositie binnen de vennootschap en de daarbij behorende lidmaatschapsrechten. Ik zou menen van niet. Bepalend is dat de desbetreffende belanghebbende risico loopt en derhalve op zijn minst een recht op informatie toekomt.

Niettemin is het maken van onderscheid tussen de certificaathouder en de vruchtgebruiker hier van belang. De mate waarin de vruchtgebruiker recht heeft op betrokkenheid bij de vennootschap verschilt van de mate waarin de certificaathouder betrokken dient te worden. De wetgever brengt deze nuance eveneens aan. De bewilligd certificaathouder wordt sinds de wijziging van de Structuurwet, met uitsluiting van de stichting $\mathrm{AK}$, in de gelegenheid gesteld zijn belang door middel van het stemrecht kracht bij te zetten. Deze toegang tot het stemrecht was hem voor de invoering van artikel 2:118a niet gegeven en de certificaathouder bevond zich daardoor in een afhankelijke positie ten opzichte van de stichting AK. Het vruchtgebruiksysteem biedt echter reeds een kader waarbinnen de stemrechttoedeling is geregeld. ${ }^{64}$ Het bewust artikel sluit daarom de vruchtgebruiker mijns inziens terecht expliciet uit van deze stemrechttoekenning.

\subsubsection{Conchusie}

De rechtsverhoudingen zoals deze bestaan in de juridische constructies van vruchtgebruik en certificering van aandelen zijn in verregaande mate vergelijkbaar. Vergelijkbare rechtsverhoudingen zijn te onderscheiden en vergelijkbare belangen van partijen spelen een rol. Daarbij valt op dat de aandeelhouder in het vruchtgebruiksysteem een veel grotere vrijheid geniet dan bij certificering. In tegenstelling tot de stichting AK staat het de aandeelhouder in geval van vestiging van vruchtgebruik vrij zijn eigen belang na te streven. Het is voorstelbaar dat hij zodoende de belangen van de vruchtgebruiker schaadt. De met de constructie van de certificering vergelijkbare

62 Vergelijk $\$ 3.2$.

63 Wederom zij de lezer erop gewezen dat zulks uitzondering leidt ingeval van het voorbehouden vruchtgebruik bij wilsrechten. Ten anazien van dit vruchtgebruik is de substitutieregel uitgeschakeld ini art. 4:23 lid 3 met als gewolg dat de hoofdgerechtigde enkel recht op een vergoedingsverdering. Vergelijk \$3.3.2.3.

Vergelijik \$6.2.1. 
verdeling van belang en risico rechtvaardigt een strengere norm waaraan het (stem)gedrag van de bezwaarde aandeelhouder toetsbaar moet worden gemaakt.

De rechten van de bewilligd certificaathouder kennen een ontwikkeling die grotendeels terug te voeren is op de veranderende rol van de certificering in thet vennootschapsrecht: De certificering wordt meer dan eens gebruikt om de risicodragend kapitaalverschaffer buiten spel te zetten. Deze ontwikkeling, gekoppeld aan de tendens om de kapitaalverschaffer een grotere betrokkenheid te ontlokken en een grotete verantwoordelijkheid te bieden in het kader wan "corporate governance', leiden ertoe dat gesleuteld wordt aan de rechten van de certificaathouder. Daarmee wordt echter onbedoeld gesleuteld aan de rechten van de vruchtgebruiker. De vruchtgebruiker had en heeft baat bij een recht op informatie en betrokkenheid. Zonodig kan hij zijn belangen in de besluitvorming verdedigen door het aan de kaak stellen van de rechtsgeldigheid en rechtvaardigheid van de besluiten op grond van artikel $2: 8 \mathrm{j}^{\circ}$ 2:15. De koppeling met de bewilligd certificaathouder betrof in dit kader een keuze van functionaliteit. De rechten die men de vruchtgebruiker toe wenste te delen waren reeds in het bezit van de bewilligd certificaathouder. De gelijkstelling in artikel 2:88 en 2:197 lid 4 komt echter door de genoemde ontwikkeling van de certificaathoudersrechten dermate onder druk te staan dat loskoppeling mij opportuun voorkomt. De wetgever heeft deze loskoppeling feitelijk reeds ingezet door de vruchtgebruiker expliciet voor de toepassing van artikel $2: 118 \mathrm{a}$ uit te sluiten. ${ }^{65}$ In plaats van de gelijkstelling kunnen de vruchtgebruikers en pandhouders rechtstreeks de informatie- en vergaderrechten worden toegekend. Het verdient derhalve aanbeveling ten behoeve van de vruchtgebruiker - en de eventueel de pandhouder - een volledige en zelfstandige regeling daartoe in het leven te roepen.

\subsection{De trustverhouding in het Zuid-Afrikaanse recht}

\subsubsection{Inleiding: de trust in het algemeen ${ }^{66}$}

De figuur van de "trust' kent een wijd verspreid gebruik in Anglo-Amerikaanse rechtsgebieden. Voor wat betreft een definitie van een trust lijdt deze aan het zelfde

65 Helans zette zij deze gedachtegang niet door in har Vorontwerp voor de wijziging van de BV De gelijkschakeling met de certificathouder bleef, zij het met een iets andere nedactie, gehandhafd. Vergelijk $\$ 6.2 .2 .2$

66 In deze paragrat wordt voor de civilist aen introducerend beeld geschetst van de rechtsfigur "trust". Het is derhalve niet te begrijpen als een omweerlegbare kenschets van het fenomeen. Zulks zou onthogelijk in een introductie kunnen worden opgenomen onder meer vanwege de hoeveelheid soorten trusts we verschillende jurisdicties waar deze voorkomen alsook de problemen in de wertw taling Voor een diepgravende analyse van de trust en een eventuele invoering naar Nederlands recht werwijs ik kortheidshalve nat de dissertatie van AEkTSEN getitald "De trust. beschoumgen over"

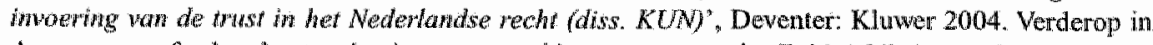
deze paragraf zal nader worden ingegaan op éen type trust onder Zuid-Afrikaans recht. 
euvel als de economische eigendonn: een sluitende definitie is niet eenvouding te geven. Zulks leidt echter nawwelijks tot problemen getuige HAYToNs beroende metafoor:

(...) like an elephant a trust is difficult to describe but easy to recognize. ${ }^{.67}$

De basis voor het trustrecht wordt gevormd door de dichotomie van het eigendom die mogelijk is in de Angelsaksische rechtssystemen. De scheiding leidt ertoe dat A 'equitable owner' kan worden en B de 'benificial owner'. Beiden staan in een juridische verhouding tot het goed, warbij A als equitable owner de beheersbevoegdheden heeft toebedeeld gekregen ten behoeve van B, de beneficial owner Een cruciaal aspect in deze rechtsverhouding is het zogenoemde instrument van 'tracing' hetwelk onder meer de beneficial owner in staat stelt zijn recht in te roepen tegen alle rechtsverkrijgers van het goed. ${ }^{68}$ Dankzij de veelzijdigheid van de trust is zij in juridisehe en geografische zin wijd verspreid en kent zij een veelheid van verschijningsvormen. Sinds het Haagse trustverdrag kent de trust ook ingang naar Nederlands recht: ${ }^{69}$ Het verdrag heeft bovendien geleidt tot de formulering van de 'Principles of European "Trust Law', 70

\subsubsection{De wording van de Zuid-Afrikanse 'testamentary trust'}

Zoals reeds eerder aangegeven kent de trust in elke jurisdictie een veelheid van verschijningsvormen. Het gaat te ver om in deze dissertatie de verschillende vormen aan bod te laten komen, laat staan de verschillen te verklaren. In plaats daarvan wordt de bespreking beperkt tot de 'testamentary trust'; de trust die bij testament in het leven wordt geroepen. Deze keuze is gestoeld op een tweetal argumenten. Ten eerste kent de ontwikkeling van de Zuid-Afrikaanse trust haar oorsprong in het testamentaire recht. Ten tweede is de "testamentary trust" qua doel en functie het meest verwant met ons systeem van het vruchtgebruik.

De oorsprong van het Zuid-Afrikaanse recht is dezelfde als van ons huidige Nederlandse recht. Na de kolonisatie door de Britten werd op het Romeins-Hollandse

67 D.J. Hayton, in: "Verfrownd met de wust" (1996), p. 3, Alsook elders gecitcerd door onder meer M.J. de Waal, SALJ 2000/3, p. 548 alsook J.M. Milo en J.M. Smits, ERPL 2000/3, p. 423.

68 Zie voor een behandelling van de "tracing" (en. Nederlands techt) H.L.E. Verhagen, in:. "Vertromish met de trust" (1996), p. 103.

69 Wet van 4 oktober 1995, houdende wettielinke bepalingen in werband met de arinvarding wan het op 1 juli 1985 te "S-Gravenhage tot and gekomen Verdrag inzake het recht dat van toepassing is op trasts en inzake de erkenning van trusts (Wet conflictenrecht trusts), Stb. 1995, 508. Uitgebreid onderwerp wan onderzoek in de dissertatie van KoppEwOL LAFORCE (M.E. Koppenol Laforce, diss. EU (1997)), die is besproken door VAW RHN VAN ALKEMADF in WPNR 6317/6318 (1998).

70 "Principhes of European Thusf Law" DJ. Hayton, S.C.J.J. Kortinann en H.L.E. Verhagen (eds.) Deventer: W.E.J. Tjeenk Willink 1999. Biesproken door JM. Milo, ERPL 2000/3, p. 533 en verder. 
recht, zoals dat in de $16^{\circ}$ en $17^{\circ}$ eeuw ook in Nederland gold, voortgebouwd. ${ }^{71}$ Uit deze ontwikkeling vloeide een zogenaamd 'mixed legal system' voort dat kenmerken draagt van zowell het 'civil law' als het 'common law' rechtssysteem. ${ }^{12}$ Als gevolg van de voornamelijk Britse invloed werden de Zuid-Afrikaanse rechters met grote regelmaat geconfronteerd met trusts. Het was aan deze rechters om antwoord te geven op de wraag wat de juridische status van de trust naar Zuid-Afrikaans recht was. De ontwikkeling wan de trust werd een proces van trial and error'. In 'Estate Kemp v' MeDonald's Trustee $e^{\text {?73 }}$ kon de Zuid-Afrikaanse rechter er niet meer onder uit de trust te duiden ${ }^{74}$ en er werd gekozen voor het 'inpassen" van de trust in een RomeinsHollandse rechtsfiguur: de fideï commissum. De keuze voor de fideï commissum werd echter door de literatuur hevig bekritiseerd ${ }^{75}$ en 1984 werd de ban doorbroken. De oplossing die in 'Braun v Blann and Botha" ${ }^{\text {"76 }}$ werd aangedragen is even simpel als - voor de meeste civilisten onder ons - subversief ${ }^{77}$. Geoordeeld werd dat de trust inmiddels een eigen plek kende in het Zuid-Afrikaanse recht en derhalve een juridisch instrument 'sui generis' vormt. ${ }^{78}$

\subsubsection{De relatie tussen de trustee en de beneficiary}

\subsubsection{Algemeen}

De Zuid-Afrikaanse trust in het algemeen vindt, naast de ontwikkeling in de jurisprudentie, sinds 1988 regeling in de 'Trust Property Control Act" ${ }^{79}$. In deze wet staat dat een (testamentary) trust word gecreëerd wanneer iemand (de 'trustee') krachtens erfrecht van de erflater (de 'settlor') het eigendom verkrijgt van een goed ('ownership of a property') op voorwaarde dat hij dit beheert ten bate van een derde persoon

71 L.M. du Plessis, 'An Imtroduction to Law' (1999), 54-56. M. Lupoi, 'Trusts' (2000), p. 297.

72 Vergelijk noot 3 supra.

73. 'Estcite Kesmp and Others w McDomatd's Thustee' 1915 SA 491 (AD).

74 Rechter SOLOMON verzuchtte: "The idea is now so firmly rooted in our practice, that it would be quite impossible to eradicate it or to seek to abolish $[i t, E C B]$. ." Estate Kemp', a.w., p. 508; evenoens geciteend door M.J. de Warl, ERPL 2000/3, p. 445.

75 M.J. de Waal, ERPL 2000/3, p. 445-446. Delarnaast wil ik in het bijzonder wijzen op de stroom aan publicatses wan de hand van H.L. SWANEPOEL in het Tydskrif wir Hedendaagse Romeins-Hollandse Reg (strekkende over 1956 en 1957). Het betreft een zevental artikelen met een gemeenschappelijke titel: 'Oor stigting, trust, fideicommissum, modus en beding ten behoewe van 'n derde".

76 'Braun V Blawn and Botha NNO and another' 1984 (2) SA 850 (AD):

77 De uitspratk schuift zoals zal blijken de naar Romeins-Hollands recht geldende "numenus clausus" sehijnbaar achteloos terzijde. Het gesloten systeem van het goederenrecht staat in Nederland echter ook onder druk, waarbij met mame de plooibaarheid wan de kwalificatie vermogensrecht aandacht krijgt. Fierower recentelijk W. Snijders, WPPNR 6607 (2005), p. 79 en verder.

78 "Braum v Blann and Botha', a.w., p. 859. Rechter JousekT citeert daarbij de woorden van een collega: 'Die Engelse terme trust en trustee is geadopteer maar nie die Engelse Trustreg nie. 'n Eie trustreg is deur ons regspraktyk en deur ons Howe ontwikkel; maar dis nog ver van voltooi." SWANEPOEL maakite de lezer in 1956 reeds bedacht op de ontwikkeling in de literatuur richting deze gedachte. H.L. Swanepoel, THRHR 1956, p. 105.

79 Act No 57 of 1988 . Hierna: de Zuid-Afrikanse trustwet. 
(de "beneficiary"). Daamaast worden de fiduciaire plichten van de trustee ten opzichte van deze beneficiary vastgelegd. De trustee dient zija functie uit te oefenen:

(...) with due care, diligence and skill which can reasonably be expected of a person who manages the affairs of another. ${ }^{81}$

Bovendien wordt voor de trustee, in het geval van de testamentary trust, de plicht in het leven geroepen de trust overeenkomstig de bepalingen in het testament te beheren.

De beneficiaries van een trust zijn onder te verdelen in twee typen: de 'income beneficiaries" en de "capital beneficaries': 82 De income beneficiaries verkrijgen, zoals het woord reeds verraadt, inkomen uit de trust. De functie van de trust is in dit geval de beneficiary van een - regelmatig - inkomen te voorzien. De capital beneficiaries daarentegen verkrijgen aan het eind van de rit het vermogen van de trust. Het is mogelijk dat in het kader van een testamentary trust beide categorieen vertegenwoordigd zijn. In een dergelijk geval ontvangt de capital beneficiary het stamkapitaal aan het eind van een bepaalde periode en ontvangt de income beneficiary de tussentijds vrijgekomen vruchten. ${ }^{83}$

\subsubsection{Bijzondere verplichtingen inzake aandelen in kapitaalvennootschappen}

De fiduciaire verplichtingen van de trustee ten aanzien van aandelen kennen een bijzondere en stapsgewijze ontwikkeling. Aanvankelijk verschilden deze verplichtingen niet wan die van andere goederen. Het uitgangspunt voor de trustee was dat hij behoudend diende te beheren. 84 In de uitspraak "Sackville West v Nourse"85 bevestigde de rechter dit uitgangspunt en oordeelde dat:

'(...) a trustee, is obliged, in dealing with and investing the money of the beneficiary, to observe due care and diligence, and not to expose it in any way to any business risks [cursief van mij; $E C B]^{\text {? }}{ }^{86}$

De trustee werd gemaand geen enkel risico te nemen bij zijn beheer. Deze plicht ontwikkelde zich later tot de verplichting zoals deze in de reeds geciteerde Trust

80 Sec. 1 van de Zuid-Afrikanse trustwet Vergelijk MM. Corbett, G. Hofmeyr en E. Kahn; "Succesion

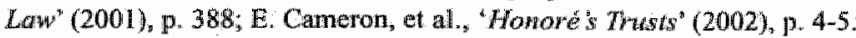

81 Sec. 9 (1) van de Zuid-A frikanase trustwet.

82. M.M. Corbett, G. Hofmeyr en E. Kahn, "Succession Law' (2001), p. 411-412; E. Cameron, en, al, 'Honorés Trusts' (2002), p. 580.

83 M.M. Corbet, G. Hofmeyr en E. Kahn, "Succestion Law" (2001), p. 412.

84 M.J. de Waal, TSAR 1999/2, p. 372.

85 "Sackville West" Nourse and another" 1925 SA 516 (CPD).

86. "Sachille West wourse and another" 1925 SA 516 (CPB), p. 535 als geciteerd door M.J. de Waal, TSAR 1999/2, p. 372. Herhaald in 'Ex parke Knight and others' 1946 SA 800 (CPD), p. 814 alwatr mog opgetnerkt wordt dat '(..) if these investments are risky and speculative it would be negligent for them to maintain them'. 
Property Act is opgenomen ${ }^{17}$ Daarenboven stipuleerde het gerechtshof in 'Peffers v Attorneys, Notaries and Coveyancers Fidelity Guarantee Fund Board of Control" zelfs wat 'suitable investments' zijn voor trusts. ${ }^{88}$ Deze klassieke benadering van de taak van de trustee met betrekking tot aandelen werd echter gewijzigd met de uitspraak 'Administrators, Estate Richards w Nichol's'. In de uitspraak werd aan de rechter de wraag voorgelegd hoe ver de beschikkingsbevoegdheid van de trustee over aandelen reikte. De rechter zocht voor beantwoording van de vraag aansluiting bij de taken en plichten van de trustee. De uitspraak nam daarbij weliswaar als uitgangspunt dat de trustee 'due care en diligence' dient te hanteren en dat hij daarbij 'prudent' te werk dient te gaan, ${ }^{90}$ maar dat zulks onder omstandigheden kan inhouden dat hij zich neét conservatief opstelt. ${ }^{91}$ Sterker nog, wan hem wordt verwacht dat hij zich waar nodig actief opstelt in zijn beheer en in dier voege van zijn beschikkingsbevoegdheid gebruik maakt.

\subsubsection{De vergelijking tussen trust en vruchtgebruik}

De raakvlakken van de trustconstructie waarbij aandelen tot het trustvermogen behoren en het vruchtgebruik op aandelen naar Nederlands recht zijn talrijk. Ten eerste bleek uit de reeds getrokken parallelien met economische eigendom en certificering dat de rechtsverhouding tussen vruchtgebruiker en aandeelhouder een fiduciair karakter draagt. De vergelijking met de trustverhouding illustreert deze conclusie verder. De wijze waarop het Nederlandse recht partijen in het geval van een vruchtgebruikconstructie vrij laat om de beheers- en beschikkingsbevoegd-heden te verdelen en in te vullen heeft niet alleen veel weg van een trust, maar is ook kenmerkend voor fiduciaire rechtsverhoudingen in het algemeen ${ }^{92}$ De conclusie dat het vruchtgebruik nauw verwant is aan, met name, de trust is niet verwonderlijk nu andere aan vruchtgebruik verwante civiele rechtsfiguren reeds aan de trust zijn gekoppeld. In dit kader moet met name gewezen worden op de eerder besproken certificering van aandelen ${ }^{93}$ en de fideï commissum ${ }^{94}$. Deze conclusie wordt verder onderschreven door

87 Zie noot 81 supra:

88 "Peffers vitorneys, Novaries and Coweyancers Fidelity Guarantee Fund Board of Control 1965 (2) SA 53 (K). p. 55. M. I. de Waal, TSAR 1999/2, p. 372-373.

89 'Administortors, Estate Richards y Nichol and anothes' 1999 (1) SA 55॥ (SCA).

90 Vergelijk de rechtsregel uit 'Sackwille West w Nourse' (supra noot 86) en sec. 9 (1) van de Trust Property Act.

91. MJ: de Wall, TSAR 1999/2, p. 374. Deze verplichting zich als een "prudent investor" op te stellen kent zijn weerklank reeds in het Nederlandse recht waar de 'prudent person rule" voor pensioenfondsen als gevolg wan de EU-pensioenrichtijn (RL 2003/41 EG) gelding heeft. Zie hierover uitgebreid R.H. Mlaatman, Ondernemingsrecht 2003/17, p. 645 en volgende.

92 Zie in het bijzonder voor wat betreft aandelen in kapitaalvennootschappen $\$ 5.5 .2$ en $\$ 5.5 .3$.

93 "Principles of European Trust Law", p. 198.

94 In Zuïd-Afrika zoals besproken kortstondig als basis woor de trust; naar huidig Nederlands erfrecht wiord op de fidei commissum de residuo zelfs de regels wan vruchtgebruik wan toepassing verklaard. Zie $\$ 3.6 .3 .2$. 
de vergelijking met de fiduciaire verplichtingen van de trustee ten aanzien van aan-

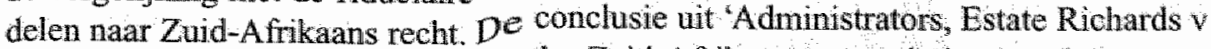
Nichol' vormt naar mijn smak de Zuid-Afrikaanse evenknie wan het arrest "MeesPierson/Ten Bos'. ${ }^{55}$ Degene die aandelen beheert ten behoeve van een derde dient deze taak met zorgvuldigheid te vervullen en behoort zich pro-actief op te stellen teneinde de verwezenlijking van risico"s te voorkomen.

\subsection{Conclusie}

De drie laterale verkenningen zoals deze in dit hoofdstuk aan bod zijn gekomen bieden een veelvoud aan andachtspurten. Om te beginnen kan, op grond van vergelijking met de figurur van de economische eigendom, geconcludeerd worden dat de vruchtgebruiker als economisch eigenaar van de aandelen recht heeft op de waardevermeerdering die hij voor deze aandelen weet te creëren. Zulks is niet minder dan rechtvaardig nu de vruchtgebruiker bij koersverlies door de hoofdgerechtigde op het matje kan worden geroepen. De constructie onderstreept dat een bijzondere regeling in het vruchtgebruik op zijn plaats zou zijn. Naar mijn smaak dient zulks mee te worden genomen in de beoordeling van de vrucht van een aandeel.

De analyse van de gelijkstelling met de bewilligde certificaathouder leert dat het vruchtgebruik in de beginfase van de certificering in hoge mate met deze rechtsverhouding viel te vergelijken. De ontwikkeling die de certificering sindsdien en voornamelijk in de laatste jaren heeft doorgemaakt, zetten de vergelijking en daamee de gelijkschakeling ex artikel 2:88 en 2:197 sterk onder druk. Bovendien maakt het vruchtgebruik op aandelen zijn eigen ontwikkeling door, waardoor de houdbaarheidsdatum van de gelijkstelling naar mijn smaak is overschreden. De vruchtgebruiker (en mogelijk in zijin kielzog de pandhouder) moeten zelfstandig rechten binnen de vennootschap krijgen. Daarbij kan in eerste instantie gedacht worden aan het in de wet rechtstreeks toekennen van informatie- en vergaderrechten aan de vruchtgebruiker. Op deze manier wordt de vruchtgebruiker - en met hem ook de pandhouder niet abusievelijk betrokken bij de ontwikkeling van de rechtspositie van de certificaathouder in het vennootschapsrecht.

De lessen uit het Zuid-Afrikaanse trustrecht dienen voorzichtig te worden getrokken. Hoewel de kwalificatie van de fiduciaire rechtsverhouding ook in het Nederlands recht dikwijls wordt benoemd - waaronder de zojuist genoemde certificering van aandelen - en Nederland met het Haagse Trustverdrag zijn grenzen reeds langer geleden opende voor de receptie van de trust, is de stap naar de ZuidAfrikaanse trust niet licht te maken. Desalniettemin zijn de parallellen té evident on zonder meer te negeren. De kenschets van de fiduciaire positie van de trustee die aandelen beheert valt zowel te plaatsen bij de aandeelhoudende hoofdgerechtigde als bij 
de beschikkingsbevoegde vruchtgebruiker. In beide gevallen is sprake van een bewoegdheidsverdeling die gepaard gaat met een fiduciaire verantwoordelijkheid ten opzichte van de ander. De algemene conclusie dat in deze gevallen sprake is van een fiduciaire rechtsverhouding brengt met zich dat de vruchtgebruiker en de aandeelhouder niet in staat moeten worden geacht ongestraft zuiver hun eigen belang na te streven. Een dergelijke opstelling kan, met name wanneer zij het bestaansdoel van de juridische constructie onevenredig schaadt, een inbreuk op de tussen partijen bestaande rechtsverhouding vormen. Uitoefening van stemrecht door de vruchtgebruiker kan genormeerd worden door de in artikel 3:207 opgenomen verplichting van de vruchtgebruiker zich als een 'goed vruchtgebruiker' te gedragen. Naar mijn smaak volgt uit de vergelijking met de trustverhouding dat het spiegelbeeld evenzeer denkbaar is. De aandeelhouder die zijn aandeel in een vruchtgebruikconstructie heeft behouden, kan zijn stemrecht slechts uitoefenen met inachtneming van de norm van een 'goed hoofdgerechtigde'. De hoofdgerechtigde is gehouden het belang van de vruchtgebruiker in het oog te houden en niet onredelijk aan te tasten. 


\section{Hoofdstuk 8}

\section{SAMENVATTING, CONCLUSIES EN AANBEVELINGEN}

In het eerste hoofdstuk wordt de plaats van het vruchtgebruik in het Nederlandse goederenrecht besproken. Het vruchtgebruik is zonder meer een van de belangrijkste en meest veelzijdige beparkte rechten die het Nederlandse goederentecht rijk is. Verschillende eigenschappen van het vruchtgebruik leiden in het bijzonder tot deze constatering. Vooreerst is het mogelijk een recht van vuchtgebruik te vestigen op alle soorten goederen, hetgeen bovendien zijn regeling in boek $3 \mathrm{BW}$ verklaart. Daar waar de andere beperkte rechten restricties kennen voor wat betreft het object van bezwaring, wordt het recht van vruchtgebrük niet op een dergelijke wijze begrensd. Daarenboven bestaat er voor de hoofdgerechtigde een grote vrijheid de verschillende bevoegdiheden die hem als rechthebbende van het goed toekomen te verdelen tussen hem en de vruchtgebruiker. Het Nederlandse goederenrecht is in dit geva bijzonder in de zin dat de vruchtgebruiker in staat kan worden gesteld de goederen die met een recht van vruchtgebruik zijn bezwaard te verteren. De vruchtgebruiker kan daarnaast in de gelegenheid. worden gesteld in verregaande mate de bevoegdheden van een eigenaar uit te oefenen. De vruchtgebruiker heeft namelijk niet alleen het genot en dus de vruchten van het bezwaarde goed, maar onder omstandigheden is hij zelfs in staat bet bezwaarde goed te vervreemden.

De verregaande mate waarin de vruchtgebruiker in staat wordt gesteld over het goed te beschikken alsmede de mogelijkheid om het recht van vruchtgebruik op alle soorten goederen te vestigen, kent echter ook een keerzijde. Zo heeft een bevoegdheidsrijke vruchtgebruiker tot gevolg dat de rechtspositie van de hoofdgerechtigde wordt verarmd. Alhoewel het uitgangspunt is dat de hoofdgerechtigde zelf de vruchtgebruiker deze bevoegdheden toekent en derhalve zelf deze verzwakking in de hand heeft, strookt dat uitgangspunt niet altijd met de praktijk. In veel voorkomende gevallen zal de hoofdgerechtigde in de vruchtgebruikverhouding niét degene zijn die intiator is wan het in het leven geroepen vruchtgebruik. Uit hoofdstuk 3 , waarin het erfrecht wordt belxandeld, blijkt dat dit rechtsgebied krachtig inzet voor wat betreft het benutten van het vruchtgebruikinstrument. De erflater kan bij - het plannen van - de verdeling van zijn nalatenschap het recht van vruchtgebruik inzetten om bepalde goederen te "splitsen" in vruchtgebruik en hoofdgerechtigdheid. Van vestiging is in dat stadium weliswaar nog geen sprake, maar de voorwaarden van verkrijging en vestiging van vruchtgebruik worden in het testament gegeven. Het nieuwe ab intestaat erfrecht maakt zelfs op dwingendrechtelijke wijze gebruik van het vruchtgebruik. De positie van de hoofdgerechtigde dient in het kader van de beschikkingsbevoegde vruchtgebruiker met name zijn wettelijke versterking te zoeken in de substitutieregeling. De substitutieregel lijdt echter onder de veelzijdigheid en de rekbaarheld van het 
recht van vruchtgebruik. De aan de substitutieregeling gekoppelde directe leer is hier de oorzaak van. Voor wat betreft de substitutie van zaken sluit de directe leer naadloos aan bij de substitutieregeling en is de hoofdgerechtigde verzekerd van het behoud van het vruchtgebruik-vermogen. De uitbreiding naar andere goederen dan zaken leidt echter tot problemen. Wanneer het bezwaarde goed niet door bezitsverschaffing kan worden geleverd, mist de directe leer en dus de substitutieregeling haar rechtsgevolg. Dit gebrek dient door middel van doorlevering te worden gerepareerd.

Het tweede hoofdstuk bevat een bespreking van het erfrecht dat stelselmatig en met grote regelmaat gebruik maakt van- het systeem van - het recht van vruchtgebruik. Zowel onder het oude als onder het nieuwe erfrecht wordt het vruchtgebruiksysteem een belangrijke plek toegedicht bij het afwikkelen van nalatenschappen. Onder het oude recht was het gebruik van het recht van vruchtgebruik veelal een kwestie van keuze door de erflater. Een keuze die, mede ingegeven door het verouderde ab intestaat erfrecht, in uiterste willen zeer geregeld werd gemaakt. De ontwikkeling van het recht wan vruchtgebruik als instrument van erfrecht heeft alles te maken met het goederenrechtelijk karakter en het toepassingsbereik van het recht van vruchtgebruik. De erflater kan er, met behulp van het vruchtgebruiksysteem, niet alleen voor zorgen dat de langstlevende na het overlijden 'in de spullen' kan blijven, maar hij kan de langstlevende tevens van een inkomen voorzien. Daarenboven voorkomt de erflater dat bestanddelen van - zijn vermogen na overlijden van de langstlevende zijn familie verlaat. Zoals in elk rechtsgebied is het ook hier niet onbelangrijk dat de constructie een fiscaalvriendelijk karakter draagt. Dit maakt het voor de erflater mogelijk de erfgenamen fiscaalrechtelijk voor een al te zware klap te behoeden. Gegeven deze eigenschappen van het recht van vruchtgebruik is het niet verwonderlijk dat het vruchtgebruik een instrument van betekenis is voor de praktijk van de 'estate planning'.

De functionaliteiten van het vruchtgebruik zijn de wetgever bij de totstandkoming van het nieuwe erfrechtelijke systeem niet ontgaan. Aanvankelijk poogde men zelfs het vruchtgebruiksysteem als ab intestaat erfrecht te omarmen. Wederom gooide de complexiteit en veelzijdigheid van het vruchtgebruik roet in het eten. Niettemin viel men wel op het recht van vruchtgebruik terug om enkele oneffenheden in het uiteindelijke "langstlevende al"-systeem van de wettelijke verdeling glad te strijken. De wetgever maakt daarbij vaardig gebruik van de mogelijkheid van het vruchtgebruik om de belangen van partijen te scheiden. Het verzorgingsvruchtgebruik in het bijzonder geeft de bruikbaarkeid en flexibiliteit van het vruchtgebruikinstrument weer. Deze vorm van vruchtgebruik zet krachtig in op de autonomie van de vruchtgebruiker. De langstlevende wordt op deze wijze een verregaande vrijheid en flexibiliteit toegekend ten aanzien van het bezwaarde goed. Hoewel de hoofdgerechtigde op grond van regels van goederenrecht een juridisch sterke positie lijkt toe te komen, moet zulks in het kader van het nieuwe erfrecht enigszins worden gerelativeerd. De substitutieregeling die de hoofd-gerechtigde een belangrijk houvast bood, wordt door het nieuwe erfreeht uitgeschakeld. Daarenboven kan de hoofdgerechtigde geconfronteerd worden met een - bij de rechter afgedwongen - recht tot vertering van de 
vruchtgebruiker. Een tweede vorm van wruchtgebruik die in het nieuwe erfrecht figureert is het voorbehouden vruchtge bruik bij uitoefening van wilsrechten. Deze vorm van vruchtgebruik legt de nadruk in eerste instantie op de hoofdgerechtigde daar zi bedoeld is om het stieffamilie-gevaar het hoofd te bieden. De wetgever was echter van mening dat de belangen van de langstevende en de hoofdgerechtigde in dit kader in balans dienden te worden gebracht en ook in dit geval moet de hoofdgenechtigde water bij de wijn doen.

De versterkte positie wan de vruchtgebruiker is te verklaren aan de hand wan de verzorgingsgedachte die in het nieuwe versterferfrecht prominente rol speelt. De langstlevende moet, binnen de grenzen van het redelijke, zoveel de mogelijk vrijheid worden gegeven om haar leven na het vooroverlijden van haar echtgenoot op dezelfde voet voort te zetten. Deze gedachte blijft overeind indien aandelen in een kapitaalvennootschap tot de nallatenschap behoren. Betreft het aandelen in een BV dan komt een beroep door de langstlevende op een verzorgingsvruchtgebruik door de (erfrechtelijke) blokkeringsregeling in het gedrang. Mede-erfgenamen die reeds aandelen in de BV houden, kunnen met gebruik van de (erfrechtelijke) blokkeringsregeling, de vestiging van het verzorgingsvruchtgebruik op de aandelen fiustreren. Wanneer deze erfgenamen de bedoelde mogelijkheid te baat nemen, moet de langstlevende genoegen nemen met een verzorgingsvruchtgebruik dat wordt gevestigd op hetgeen woor de overgedragen aandelen in de plaats treedt.

Nadat de aard en het karakter alsmede het belangrijkste toepassingsgebied van het recht van vruchtgebruik in het algemeen zijn behandeld, wordt in hoofdstuk 4 het ontstaan van het recht van vruchtgebruik op een aandeel in een kapitaal-vennootschap voor het voetlicht gebracht. De wijze warop een recht van vruchtgebruik op een aandeel tot stand komt is zeer uiteenlopend. Niet in alle gevallen is de goederenrechtelijke en/of de wennootschapsrechtelijke positie van de vruchtgebruiker eenvoudig weer te geven. De verschillende regelingen die de overdracht van een aandeel en derhalve ook de vestiging van een recht van vrucht-gebruik vonmgeven, hebben niet zonder meer oog woor een mogelijke vuchtgebruiker. In geval van een aandeel oj naam richten de problemen zich op het smeden van de band met de betrokken vennootschap. Betekening door de vruchtgebruiker van de notariële akte is, hoewel niet constitutief, wel geraden. De vruchttgebruiker is gebaat bij de kenbaarheid van zijn bestaan bij de vennootschap. Dit probleem wordt ingeval van een beursgenoteende vennootschap geëcarteerd doordat de erkenning daar onderdeel witmaakt van de eisen voor vestiging. Het recht van wruchtgebruik kan derhalve niet zonder medeweten van de vennootschap worden gevestigd.

De diversiteit die zich openbaart bij het andeel aan toonder brengt een aantal verschillende problemen met zich. Het belangrijkste probleem is wijziging van het goederenrechtelijke karakter van het toonderaandel. Het toonderbewijs wordt als gevolg van het systeem van de WGE geleidelijk aan vervangen door een recht op naam sü generis. Hoewel fysieke toonderbewijzen nog wel bestaan wordt het merendeal van de toonderaandelen verhandeld in het systeem van de WoE hetwelk een recht op 
naam van eigen aard creëert. Deze ontwikkeling leidt ertoe dat het object van vruchtgebruiker eveneens aan verandering onderhevig is. Deze laatste conclusie is op haar beurt relevant woor de inhoud van het wruchtgebruik. Immers; de aard van het object bepaalt de reikwijdte van de bevoegdheden van de wruchtgebruiker.

Niet alleen de veranderende goederenrechtelijke aard van het toonderbewijs zorgt voor problemen. Ook de goederenrechtelijke functie van bezit van een toonderbewijs leldt in het kader van het recht van vruchtgebruik tot complicaties. In het goederenrechtelijke gedeelte werd reeds het probleen aangekaart dat onduidelijk is wat aan de vruchtgebruiker geleverd dient te worden. In dit verband werd voorgesteld de feitelijke machtsverschaffing aan de vnuchtgebruiker voor te schrijven. In het kader van het klassieke toonderstuk is een verdere nuancering echter geboden. Voorkomen moet worden dat de vruchtgebruiker door de voorgestelde feitelijke machtsverschaffing zich - te kwader trouw - zou kunnen legitimeren als aandeelhouder. Met het voorstel de onderhandse akte in dit kader te introduceren heb ik gepoogd dit probleem het hoofd te bieden en tezelfdertijd aansluiting te zoeken bij vergelijkbare bestaande regelingen."

Tot besluit heb ik in dit hoofdstuk de onduidelijkheid van de vennootschaps-rechtelijke positie van de vruchtgebruiker in het systeen van de WGE aan de ordegesteld. De voorstellen wan UNIKEN VENEMA in dit kader verdienen dringend overweging. Zowel de stemgerechtigde- als de (slechts) vergadergerechtigde vruchtgebruiker verdienen een expliciete regeling in de WGE.

Daar waar hoofdstuk 4 de totstandkoming van een recht van wruchtgebruik op een aandeel schetste concentreert hoofdstuk 5 zich op de relatie vruchtgebruiker - aandeelhouder. Het toepassen van de bevoegdheden die de vruchtgebruiker op grond van titel 8 van Boek $3 \mathrm{BW}$ toekomen op de complexe verhouding die het aandeel in de kapitaalvennootschap in zich draagt, is geen eenvoudige opgave gebleken. Debet aan deze conclusie is niet alleen het complexe rechtskarakter van het vruchtgebruik zelf, maar ook de diversiteit en complexiteit van het object van vruchtgebruik: een aandeel in een kapitaalvennootschap. Het rechtskarakter van een aandeel kan per aandeel en zelfs per vennootschap - verschillen, hetgeen als gevolg van de goederenrechtelijke eigenschappen van het recht van vruchtgebruik rechtstreeks invloed heeft op de rechtspositie wan de vruchtgebruiker. Een goed begrip wan het rechtskarakter van het bezwaarde aandeel alsook de bestemming die de insteller van het vruchtgebruk daaraan gaf, wormen het uitgangspunt voor de rechtspositie van de vruchtgebruiker. Wanneer, zoals ik in hoofdstuk 5 heb gedaan, een duidelijk onderscheid wordt gemaakt tussen de bevoegdheden van gebruik en verbruik enerzijds en de diverse

I Hier past dosaliniettemin de relativering dat het bestam van toonderstukken geen lang leven beschoren lijkt. Zo spreekt UNKKEN VENEMA bij de behandeling wan de ant. 10 en 13 WoE beeldend van "zuigkrachtbepalingen". Hij geef daamee aan dat effecten en dus ook (nog) bestaande toonderaandelen door het systeem van de WGE "worden a angezogen en binnengezogen" . C.A. Uniken Venema, 'Efertengiro-inech in beweging' $(2003), \mathrm{p} .213$. 
vormen van beschikkingsbevoegdheid anderzijds, is de rechtspositie van zowel de vruchtgebruiker als de bezwaarde aandeelhouder het meest gediend bij de nadruk op het normenkader van de laatste categorie. De regelingen betreffende de vervreemdingsbevoegdheid (artikel 3:212 jid 1) alsmede de beschikkingsbevoegdheden ${ }^{2}$ bieden een normenkader dat op regelend niveau voor de vruchtgebruiker de juiste uitgangspunten herbergt en daarnaast de insteller van her vruchtgebruik voldoende gelegenheild biedt dat kader aan te scherpen.

De juridische kwalificatie van een vrucht van een aandeel kent sinds "Pierlot/ Kreemer' geen substantiële wijziging. De vrucht van een aandeel wordt, naast wettelijke en statutaire eisen, nog immer door een besluit van de AvA gecreëerd. De creatie draagt derhalve een subjectief element dat naar mijn smaak, in de relatie vruchtgebruiker - aandeelhouder, naar regels van vennootschapsrecht kan worden ingekaderd. De regels van vennootschapsrecht bepalen (de omvang van) de vrucht. De aandeelhouder is mijns inziens echter gehouden bij de stemuitoefening in het kader van het winstbesluit zuiver het belang van de vruchtgebruiker na te streven. Deze gedacht kan gekoppeld worden aan de invulling van de fiduciaire verhouding tussen partijen. Op grond van het uitblijven van uitspraken in het kader van vruchten van aandelen is er geen reden aan te nemen dat de Hoge Raad zijn in 1958 opgetekende visie hierover aanstonds zal wijzigen. Dit laat echter onverlet dat de ruimte voor groei van het vruchtgebruik-begrip ontegenzeggelijk aanwezig is. Met name het feit dat artikel 3:9 de verkeersopvatting als uitgangspunt neemt voor de bepaling van de goederenrechtelijke vrucht maakt dit mogelijk. In hoofdstuk 2 heb ik reeds benadrukt dat dit uitgangspunt ertoe leidt dat hetgeen de betrokken praktijk tot wrucht bestempelt, kan uitgroeien tot de goederenrechtelijke vrucht. Daarenboven geven andere aspecten van vruchtgebruik op een aandeel de vruchtgebruiker de mogelijkheid de potentiële vermogensgroei van het bezwaarde goed te benutten. In dit kader sloot ik de vorige paragraaf af met de uitwerking van de uitgeschakelde substitutiebepaling. Verrassenderwijs creëert deze bepaling van erfrecht een rechtsverhouding die in hoge mate vergelijkbaar is met ons oude 'oneigenlijke' vruchtgebruik. De mogelijkheid om vruchtgebruik op aandelen aldus als verzorgingsinstrument in te zetten biedt mijns inziens perspectieven voor de erfrechtelijke vruchtgebruiker

Met de verkrijging van een aandieel in een kapitaalvennootschap treedt de rechthebbende in een lidmaatschapsverhouding met deze vennootschap. Voor wat betreft de vertegenwoordiging van zijn belangen in de vennootschap is de vruchtgebruiker derhalve afhankelijk van de aandeelhouder. Het feit dat het stemrecht in de AvA bij de aandeelhouder blijft berusten benadrukt deze afhankelijkheid. De wetgever heeft echter ook mogelijk gemaakt het stemrecht aan de vruchtgebruiker over te dragen. De stemoverdracht kan alleen plaats hebben indien zulks statutair niet onmogelijk is gemaakt. De wet schnift sinds de invoering van het nieuwe erfrecht de overdracht aan de vruchtgebruiker ex artikel 4:19 en 4:21 zelfs voor. Daarmee wordt naar mijn 
smaak bewust uiting gegeven aan de noodzaak de vruchtgebruiker rechtstreeks te betrekken in - de besluitvorming van - de vennootschap. Dit wil echter niet zeggen dat deze betrokkenheid alleen door middel van het stemrecht vorm kan krijgen. Zo heeft de stemgerechtigde vruchtgebruiker van rechtswege de beschikking over de rechten van de bewilligd certificaathouder. De niet-stemgerechtigde vruchtgebruiker wordt slechts voorwaardelijk toegellaten tot deze rechten. Net als biy de stemrecht-toekenning spellen de statuten van de vennootschap in dit geval een bepalende rol bij de toekenning wan vennootschapsrechtelijke rechten. Indien de vruchtgebruiker de rechten van de bewilligd certificaathouder heeft ontvangen, of in geval van de NV hem deze niet worden onthouden, wordt de redelijkheids- en billijkheidskring van artikel $2: 8$ eveneens voor hem ontsloten. Dit biedt de vruchtgebruiker aanvullende rechtsinstrumenten om zijn belangen in de vennootschap te bewaken. Met name de besluiten die in onredelijke mate inbreuk maken op zijn gerechtvaardigde belangen zijn woor vernietiging vatbaar. Door middel van een vergelijking met de certificaathouder en de toepassing van artikel $2: 8 \mathrm{kwam}$ ik tot de conclusie dat het artikel de vruchtgebruiker in het bijzonder voet aan de grond kan bieden bij - de beoordeling van het winstbesluit.

De rechtspositie die de vruchtgebruiker als gevolg van het ontvangen van het stemrecht, het ontvangen van certificaathoudersrechten en het toetreden tot de redelijkheids-en billijksheidsdkring van artikel $2: 8$ bekleedt is niet geheel gevrijwaard van verandering of verslechtering. Wijzigingen in de vennootschaps-structuur kunnen deze verslechtering inluiden. Daarnaast kan de vruchtgebruiker bijvoorbeeld op individuele basis zijn stemrecht worden ontnomen. De bezwaarde aandeelhouder kan daarenboven worden uitgestoten of kan eigener beweging uittreden. In beide gevallen ontbreekt het de wet aan aandacht voor de positie van de betrokken vruchtgebruiker met als gevolg dat teruggevallen moet worden op de regels van het goederenrecht. De aldus ontstane situaties zijn echter veelal niet verkieselijk voor partijen en kunnen beter door proactief handelen voorkomen worden. In geval van juridische fusie en splitsing heeft de wetgever wél aandacht gehad voor de positie van de beperkt gerechtigde. De geboden regeling reikt echter niet verder dan een vennootschapsrechtelijke toepassing van de substitutieregel: De lidmaatschapsrechten van de vruchtgebruiker staan ook in dit geval op de tocht. Eenmaal verworven rechten dienen naar mijn smaak echter door de verkrijgende vennootschap gerespecteerd te worden. Zulks lijdt slechts uitzondering in het geval de statuten de niet-stemgerechtigde vruchtgebruiker de certificaathoudersrechten onthouden.

Tot slot verbreed ik in het laatste hoofdstuk de blik. De drie laterale verkenningen zoals deze in dit hoofdstuk aan bod zijn gekomen bieden een veelvoud aan aandlachtspunten. Om te beginnen kan, op grond van vergelijking met de figuur van de economische eigendom, geconcludeerd worden dat de vruchtgebruiker als economisch eigenaar van de aandelen recht heeft op de waardevermeerdering die hij voor deze aandelen weet te creëren. Zulks is niet minder dan rechtvaardig nu de vruchtgebruiker bij koersverlies door de hoofdgerechtigde op het matje kan worden geroe- 
pen. De constructie onderstree $p^{t}$ zijn plaats zou zijn. Naar mijp beoordeling van de vrucht van en aandeel.

De analyse van de gelijkstelling met de bewilligde certificaathouder leert dat het vruchtgebruik in de beginfase van de certificering in hoge mate met deze rechtsverhouding viel te vergelijken. De ontwikkeling die de certificering sindsdien en voornamelijk in de laatste jaren heeft doorgemaakt, zetten de vergelijking en daarmee de gelijkschakeling ex artikel $2: 88$ en 2:197 sterk onder druk. Bovendien maakt het vruchtgebruik op aandelen zijn eigen ontwikkeling door, waardoor de houdbaarheidsdatum van de gelijkstelling naar mijn smaak is overschreden. De vruchtgebruiker (en mogelijk in zijn kielzog de pandhouder) moet zelfstandig rechten binnen de vennootschap krijgen. Daarbij kan in eerste instantie gedacht worden aan het in de wet rechtstreeks toekennen van informatie- en vergaderrechten aan de vruchtgebruiker. Op deze manier wordt de vruchtgebruiker - en met hem ook de pandhouder niet abusievelijk betrokken bij de ontwikkeling van de rechtspositie van de certificaathouder in het vennootschapsrecht.

De lessen uit het Zuid-Afrikaanse trustrecht dienen voorzichtig te worden getrokken. Hoewel de kwalificatie van de fiduciaire rechtsverhouding ook in het Nederlands recht dikwijls wordt benoemd - waaronder de zojuist genoemde certificering van aandelen - en Nederland met het Haagse Trustverdrag zijn grenzen reeds langer geleden opende voor de receptie van de trust, is de stap naar de Zuid-A frikaanse trust niet licht te maken. Desalniettemin zijn de parallellen té evident om zonder meer te negeren. De kenschets van de fiduciaire positie van de trustee die aandelen beheert valt zowel te plaatsen bij de aandeelhoudende hoofdgerechtigde als bij de beschikkingsbevoegde vruchtgebruiker. In beide gevallen is sprake van een bevoegdheidsverdeling die gepaard gaat met een fiduciaire verantwoordelijkheid ten opzichte van de ander. De algemene conclusie dlat in deze gevallen sprake is van een fiduciaire rechtsverhouding brengt met zich dat de vruchtgebruiker en de aandeelhouder niet in staat moeten worden geacht ongestraft zuiver hun eigen belang na te streven. Een dergelijke opstelling kan, met name wanneer zij het bestaansdoel van de juridische constructie onevenredig schaadt, een inbreuk op de tussen partijen bestaande rechtsverhouding vormen. Uitoefening van stemrecht door de vruchtgebruiker kan genormeerd worden door de in artikel 3:207 opgenomen verplichting van de vruchtgebruiker zich als een 'goed vruchtgebruiker' te gedragen. Naar mijn smaak volgt uit de vergelijking met de trustverhouding dat het spiegelbeeld evenzeer denkbaar is. De aandeelhouder die zijn aandeel in een vruchtgebruikconstructie heeft behouden, kan zijn stemrecht slechts uitoefenen met inachtneming van de norm van een 'goed hoofd-gerechtigde'. De hoofdgerechtigde is gehouden het belang van de vruchtgebruiker in het oog te houden en niet onredelijk aan te tasten. 

Bijlage A

\section{STATUTEN BEURSGENOTEERDE VENNOOTSCHAPPEN}

\begin{tabular}{|c|c|c|c|c|c|c|c|c|}
\hline \multirow[t]{2}{*}{$\begin{array}{l}\text { AEX } \\
\text { Naam }\end{array}$} & \multirow{2}{*}{ d.d. } & \multirow{2}{*}{ taal } & \multicolumn{4}{|c|}{ cf-rechten } & \multirow[t]{2}{*}{ toel. } & \multirow[t]{2}{*}{ stemr: } \\
\hline & & & AH- & VG+ & $V_{G}-$ & Art. & & \\
\hline ABN Amro* & sept '04 & $\mathrm{NL}$ & $\mathrm{jat}$ & ja & nee & $15(3)$ & & \\
\hline Aegon & mei 03 & NL & ja & ja & jà & $15(3)$ & $1-b$ & \\
\hline Ahold" & mrt 04 & NL & ja & ja & nee & $10(3)$ & & \\
\hline Akzo Nabel' & jul "04 & $\mathrm{E}$ & $\mathrm{ja}$ & ja & nee & 45 (1) & $1-\mathrm{c}$ & \\
\hline ASML" & mit 04 & $\mathrm{E}$ & $\mathrm{ja}$ & ja & nee & $12(2)$ & & \\
\hline Buhrmann" & meil '04 & $\mathrm{NL}$ & ja & ja & nee & $16(1)$ & & \\
\hline DSM & sept '04 & NL & ja & ja & $\mathrm{ja}$ & $15(5)$ & $1 \omega$ & \\
\hline Fortis & jun 04 & NL & $\mathrm{ja}$ & ja & ja & & $1-\mathrm{a}$ & \\
\hline Getronics" & now 02 & $\mathrm{NL}$ & $\mathrm{ja}$ & ja & nee & $12(5)$ & & $8 A(2)^{\circ}$ \\
\hline Hagemeyer & febr '04 & NL. & ja & $\mathrm{ja}$ & nee & $9(4)$ & & \\
\hline Heineken & mei '04 & $\mathrm{NL}$ & ja & $\mathrm{ja}$ & ja & $1-a$ & & \\
\hline IHC Caland & jul 01 & $\mathrm{NL}$ & ja. & $\mathrm{ja}$ & ja & $1-a$ & & \\
\hline ING Groep" & jun 03 & $\mathrm{NL}$ & nee & nee & nee & 112 & & \\
\hline Shell & mei 02 & $\mathrm{NL}$ & ja & ja & nee & $29(5)$ & & $14(2)$ \\
\hline $\mathrm{KPN}^{*}$ & mei 02 & $\mathrm{NL}$ & ja & ja & nee & $19(1)$ & & \\
\hline V/d Moolen" & apr 94 & $\mathrm{NL}$ & ja & ja & nee & $12(3)$ & & \\
\hline Numico" & jul '04 & $\mathrm{NL}$ & ja & $\mathrm{ja}$ & nee & $12(3)$ & & \\
\hline Philips & mei "00 & $\mathrm{E}$ & ja & $\mathrm{ja}$ & $\mathrm{ja}$ & $1 \times a$ & & \\
\hline $\mathrm{TPG}^{\circ}$ & apr "04 & $\mathrm{NL}$ & ja. & ja & nee & 19 (I) & & \\
\hline Unilever & mei 04 & $\mathrm{NL}$ & ja. & ja & ja & alg.bep. & 3 & \\
\hline Versatel* & okt "02 & $\mathrm{NL}$ & $\mathrm{ja}$ & ja & nee & $12(3)$ & & $12(2)^{*}$ \\
\hline VNU* & nov "04 & $\mathrm{NL}$ & jat & ja & nee & $12(4)$ & & \\
\hline Kluwer* & mirt "02 & NL & ja & ja & nee & $14(6)$ & & \\
\hline
\end{tabular}

- = vennootschappen welke de cf-rechten aan de VG-onthouden

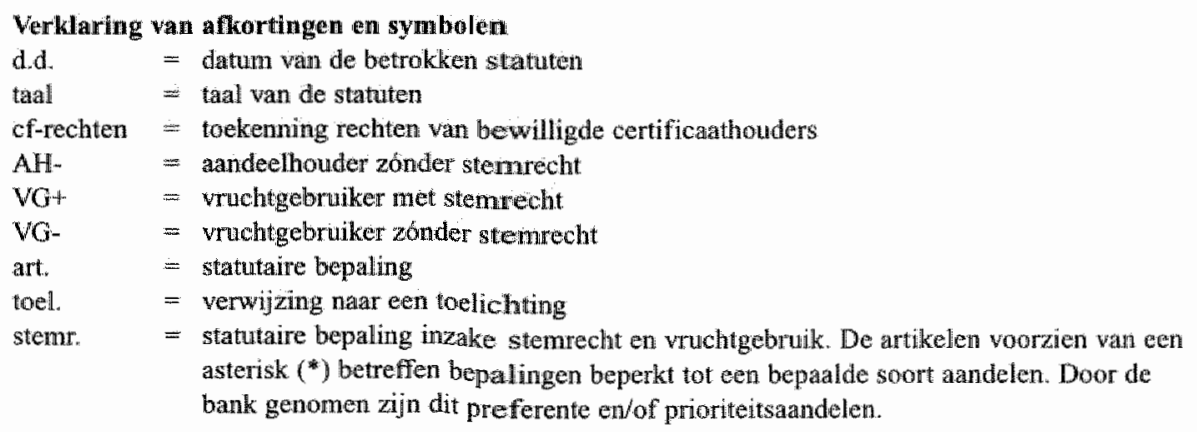

1 Ondanks de tendens naar een doorzichtiger bestuur verleende Reed Elsevier NV geen medewerking aan dit onderzoek. 
. 


\section{Bijlage B}

\section{STATUTEN BEURSGENOTEERDE VENNOOTSCHAPPEN}

\begin{tabular}{|c|c|c|c|c|c|c|c|c|}
\hline \multirow[t]{2}{*}{$\begin{array}{l}\mathrm{AMX} \\
\text { Naam }\end{array}$} & \multirow{2}{*}{ d.d. } & \multirow{2}{*}{ taal } & \multicolumn{4}{|c|}{ cf-rechten } & \multirow[t]{2}{*}{ toel. } & \multirow[t]{2}{*}{ stemr: } \\
\hline & & & AH & $\mathrm{VG}^{+}$ & VG:- & Art: & & \\
\hline Air FranceKLM* & mei " 04 & $\mathbb{E}$ & ja & ja & nee & 39 & & $15(2)$ \\
\hline ASMI & okt 01 & NL & ja & ja & ja & & $1-3$ & 16 \\
\hline BAM Groep & noei 03 & NL & ja & ja & ja & & $1-a$ & \\
\hline Boskalis* & "05 & $\mathrm{NL}$ & jat & ja & nee & $12(2)$ & & \\
\hline Corio" & dec 04 & NL & ja & ja & nex & 12 & & \\
\hline $\operatorname{csM}$ & $\mathrm{jul}=02$ & $\mathrm{NL}$ & jat & ja & ja & $5(6)$ & $1-b$ & \\
\hline Fugro* & sept 04 & NL & ja & ja & nee & $14(2)$ & & 17.19 \\
\hline Heijmans" & jun 02 & NIL & ja & ja & nee & $14(2)$ & & $18-20$ \\
\hline Imtech & okt "01 & NL & ja & ja & nee: & $8(14)$ & & \\
\hline Laurus* & nox: "04 & NL & ja & ja & nee & $12(1)$ & & \\
\hline Nutreco & dec 02 & NIL & $\mathrm{ja}$ & $\mathrm{ja}$ & ja & $5(14)$ & $1-d$ & $5(12)$ \\
\hline Oce & $\operatorname{sept}^{3} 04$ & $\mathrm{NL}$ & ja & ja & ja & & $1-\mathrm{a}$ & \\
\hline P\&O NedLloyd ${ }^{2}$ & & NL & ja & ja & ja & 24 & $1-d$ & \\
\hline Ranustad & jul $=03$ & $\mathrm{E}$ & ja & ja & ja & $5(3)$ & $1-\mathrm{c}$ & \\
\hline Rodamco Europe & $\mathrm{atag} \times 04$ & NL & ja & jia & ja & & $1+a$ & \\
\hline Stork & mart ${ }^{*} 03$ & $\mathrm{NL}$ & ja & jika & ja & $13(2)$ & $1-i$ & \\
\hline Vastned Retail & apr $" 04$ & NL & ja & jia & ja & $24(2)$ & $1-0$ & \\
\hline Vopak & jun 02 & NL & ja & jata & ja & & $1-\mathrm{a}$ & \\
\hline Wereldlltave" & mei" 01 & NL & ja & $\mathrm{j} / \mathrm{a}$ & nee: & $13(2)$ & & \\
\hline Wessanen ${ }^{*}$ & apr '04 & $\mathrm{NL}$ & ja & jia & nee & $13(1)$ & & $11(2)$ \\
\hline
\end{tabular}

- = vennootschappen welke de ef-rechten a an de VG-onthouden

\section{Verklaring van afkortingen}

d.d. $\quad=$ datum van de betrokken statuten

tail = tas.l van de statutien

cl-rechten = tokenning rechten wan bewilligde certifichathouders

AH- $\quad=$ andeelhouder zonder steminecht

$\mathrm{VG} * \quad=$ vruchtgebraiker met stemrecht

$\mathrm{VG-} \quad=$ vruchtgebruiker zónder stemrecht

art. $\quad=$ statutare bepaling

toel. $\quad=$ verwijzing nar een toelichting

stemr. $\quad=$ statutaire (blokkering)bepaling inzake stemrecht en vruchtgebruk. De artikelen woozien wan een asterisk ( ${ }^{2}$ ) betreften bepalingen beperkt tot een bepalde soort aandelen. Door de bank genomen ziju dit preferemte en/of prioriteitsaandelen.

1 Nief opgenomen in dit overzicht zijn: Hunter Douglas NV Corms Group Plc en LogicaCMG. Het bitreft vennootschappen naar buitenlands recht.

2 De op de website gepubliceerde statuten vermelden gecn dahum. 


\section{Toelichtingen}

Ad 1. De conclusie voor deze wennootschappen is dat de statuten de rechten van de certificaathouders niét aan de vruchtgebruiker zonder stemrecht onthouden. Er is sprake van een varu de volgende gevallen:

a. De statuten maken geen enkele melding van de rechten van beperkte gerechigden

b. De statuten maken weliswaar melding, maar verwijzen slechts naar de wet: "Ten aanzien wan vruchtgebrtiker (...)' gelden de desbetreffende wettelijke bepalingen

c. De statuten stellen dat de rechten toekomen woorzover deze niet bij westiging zijn onthouden.

d. De statuten kennen de aandeelhouder zonder stemrecht en de truchtgebruiker met stemrecht de rechten toe, maar later de vruchtgebritiker zonder stemrecht onbesproken.

Ad 2. Artikel 11 hid 2 en 3 van de statuten wan de ING Groep NV luiden:

'2. Indien het vruchtgebruik op aandelen is gevestigd, komt het stemrecht op de desbetreffende aandelen uitsluitend de aandeethouder toe en kan dit niet worden toegekend aan de vruchtgebruiker. 3. De wruchtgebruiker heeft niet de rechten die door de wet zijn toegekend aan de houders van met medewerking wan de ventootschap vitgegeven certificaten van aandelen".

De bepalingen zijn - gedeeltelijk - in strijd met regels van dwingend recht. Vergelijk woor het rechtsgewolg hoofdstuk $6-$ noot 20 .

\section{Ad 3. Unilever NV:}

In de algemene bepalingen wordt de vruchtgebruiker zonder stemrecht uitgesloten wan de vergaderrechten. Nu de wet gebruik maakt van de tenzij-formulering en de becoelde vruchtgebniker niet is vilgezonderd van de andere rechten, conchdeer ik dat de overige rechten van de bewilligde certificaathouder hem wel toekomen. A priori geldt dit voor het enquêterecht dat immers ook de houder van miet bewilligde certificaten toekomt. 


\section{LIJST VAN GERAADPLEE GDE LITERATUUR}

\section{Nederland}

Asser/Van der Grinten-Kortmann 2-I (2004)

S.C.J.J. Kortmann, Mr. C. Asser"s Handleiding tot de beoefening van het Nederlands Burgerlijk Recht. Vertegenwoordiging en rechtspersoon. De vertegenwoordiging. 2-I. Deventer: Kluwer 2004.

Asser/Maeijer 2-III (2000)

J.M.M. Maeijer, Mr. C. Asser's Handleiding tot de beoefening van het Nederlands Burgelijk Recht. Vertegenwoordiging en rechtspersoon. De naamloze en besloten vennootschap. 2-III. Deventer: W.E.J. Tjeenk Willink 2000.

\section{Asser/Beekhuis 3-I (1957)}

J.H. Beekhuis, Mr. C. Asser's Handleiding tot de beoefening van het Nederlands Burgerlijk Recht. Zakenrecht. Algemeen deel. 3-I. Zwolle: W.E.J. Tjeenk Willink 1957.

\section{Asser/Mijnssen-De Haan 3-I (1992)}

F.H.J. Mijnssen \& P. de Haan, Mr. C. Asser's Handleiding tot de beoefening van het Nederlands Burgerlijk Recht. Goederenrecht. Algemeen goederenrecht. 3-I. Zwolle: W.E.J. Tjeenk Willink 1992.

Asser/Mijnssen-De Haan 3-I (2001)

F.H.J. Mijnssen \& P. de Haan, Mr. C. Asser "s Handleiding tot de beoefening van het Nederlands Burgerlijk Recht. Goederenrecht. Algemeen goederenrecht. 3-I, Deventer: W.E.J. Tjeenk Willink 2001.

\section{Asser/Mijnssen-Van Dam-Van Velten 3-II (2002)}

C.C. van Dam, F.H.J. Mijnssen en A.A. van Velten, Mr. C. Asser's Handleiding tot de beoefening van het Nederlands Burgerlijk Recht. Goederenrecht. Zakelijke rechten. 3-II. Deventer: Kluwer 2002.

Asser/Hartkamp 4-II (2001)

A.S. Hartkamp, Mr. C. Asser's Handleiding tot de beoefening van het Nederlands Burgerlijk Recht. Verbintenissenrecht. Algemene leer der overeenkomsten. 4-II. Deventer: W.E.J. Tjeenk Willink 2001. 
Asser/Van der Ploeg-Perrick 6 (1996)

S. Perrick, Mr. C. Asser's Handleiding tot de beoefening van het Nederlands Burgerlijk Recht. Erfrecht. 6. Deventer: WE.J. Tjeenk Willink 1996.

Asser/Perrick 6A (2002)

S. Perrick, Mr. C. Asser's Handleidling tot de beoefening van het Nederlands Burgerlijk Recht. Erfrecht en schenking. 6A. Deventer: Kluwer 2002.

Beek, J. van der

J. van der Beek, 'Aspecten van levering en verpanding van Wge-aandelen', Ondernemingsrecht 2003/7, p. 244-247.

Beekhuis, J.H.

J.H. Beekhuis, "Nieuwe vormen van economische eigendom in Nederlands recht", in: G.J.A. Baert (red.), Liber Amicorum Jan Ronse, Brussel: Story-Scientia 1986, p. $581-595$.

Berenschot, E.B.

E.B. Berenschot, "Enige aspecten van de plaats van het vruchtgebruik in het vermogensrechtelijk systeem', WPNR 5730 (1985), p. 170-179.

\section{Bertrams, J.I}

J.J. Bertrams, "De wettelijke geschillenregeling', in: H. Pasman, G.M.F. Snijders en W.J.M. van Andel (red), Overnemen. Een hele onderneming, Deventer: Kluwer 1998, p. 67-97.

Biemans, J.W.A.

J.W.A. Biemans, 'Kritische kanttekeningen bij wetswoorstel 28878 (cessie zonder mededelingsvereiste)', WPNR 6584 (2004), p. 532-539.

\section{Biemans en Sohim}

J.W.A. Biemans \& B.F.L.M. Schim, 'Reactie op "Privaatrechtelijke aspecten van giraal effectenverkeer" van mr.drs. M. Haentjens in WPNR (2004) 6582", WPNR 6602 (2004), p. $986-988$.

Bier, B.

B. Bier, Uitkeringen aan aandeelhouders (diss. EU), Uitgave vanwege het Instituut voor Ondernemingstecht Rijksuniversiteit Groningen (42), Deventer: Kluwer 2003.

Blanco Fernández; J.M.

J.M. Blanco Fernández, "Het toepassingsbereik van artikel 2:8 BW", in: S.C.J.J. Kortmann, W.A.K. Rank, M.H.E. Rongen, G. van Solinge en H.L.E. Verhagen 
(red.), Onderneming en 10 jalr neww burgerlik recht. Serie Onderneming en Recht Deel 24, Deventer: KJuwer 2002, p. 125-142.

Blokland en Stollenwerck

P. Blokland \& A.H.N. Stollenwerck, 'De uiterste will van de bezwaarde en het overschot (I)", WPNR 6574 (2004), p. 291-294

P. Blokland \& A.H.N. Stollenwerck, 'De uiterste wil van de bezwaarde en het overschot (II, slot)', WPNR 6575 (2004), p. 307-311.

Blom, M.A.

M.A. Blom, 'Dematerialisatie van effecten en ontwikkelingen rond de Wge', in: S.C.J.J. Kortmann, W.A.K. Rank, M.H.E. Rongen, G. van Solinge en H.L.E. Verhagen (red.), Ondememing en effecten. Serie Ondernening en Recht. Deel 13, Deventer: W.E.J. Tjeenk Willink 1998, p. 183-206.

M.A. Blom, "Effecten en the law of the intermediary", Ondernemingsrecht $1999 / 14$, p. $376-384$.

\section{Boer, J. den}

J. den Boer, 'Naar een rationeel waarderingstijdpstip bij de uitkoop- en de geschillenregeling", WPNR 6487 (2002), p. 339-346.

Boogert, M.W. van den

M.W. den Boogert, 'Het girale aandeel; het einde van het toonder-regime?' in: J.M.M. Maeijer, H.M.N. Schonis, F.J.P. van den Ingh, G, van Solinge en M. van Olffen (red.), Een bewezen bestaansrecht. Lustrumbundel Vereniging voor Effectenrecht. Serie wanwege het Van der Heijden-instituat (71), Deventer: Kluwer 2002, p. 25-36.

\section{Bos en Hamers}

E.C. Bos \& J.J.A. Hamers, "Babylonische stemverwarring", WPNR 6452 (2001), p. $645-646$.

E.C. Bos \& I.J.A. Hamers, "Van de SER, de stichting Administratiekantoor, de certificaathouder, diens stemrecht en dingen die echt moeten veranderen", Stichting \& Vereniging $2001 / 5$, p. 89-94.

Brahn, O.K.

O.K. Brahn, "Vruchtgebruik en pandrecht op aandelen volgens Boek $2 \mathrm{BW}^{\text {" }}$ TWVS 1975-6, p. 195-203. 
Brahn en Reehuis

O.K. Brahn \& W.H.M. Reehuis, Overdracht. Monografieën Nieuw BW-B6a, D venter: KJuwer 1997.

Bregstein, M.H.

M.H. Bregstein, "Rechtsvragen I'; WPNR 4335 (1954), p. 91-92.

Bulten, C.DI:

C.D.J. Bulten, 'Herziening wan de geschillenregeling: grondige verbouwing o likje verf?' WPNR 6605 (2005), p. 45-51.

Burgenhart, W.

W. Burgerhart, "Erfrechtelijk rekenwerk bij een beroep op een 'bloot-eigendomswilsrecht", WPNR 6424 (2000), p. 827-830. W. Burgerhart, 'Een stichting als erflaters latste wil', Stichting \& Vereniging
$2002 / 1$, p. $16-22$.

van der Burght en Ebben

Gr. van der Burght \& E.W.J. Ebben, 'De Eerste Kamer en het wetsvoorstel erfrecht (I)', WPNR 6349 (1999), p. 197-200.

Gr. van der Burght \& E.W.J. Ebben, "De Eerste Kamer en het wetsvoorstel erfrecht (II, slot)', WPNR 6350 (1999), p. 214-216.

Coebergh, H.P.J.M.

H.P.J.M. Coebergh, "Vruchtgebruik van aandelen", $N V 36$ (1958), p. 164-166. NV 52 (1974), p. $75-80$.

Commissie Erfrecht Commissie Erfrecht, "Twee nieuwe voorstellen woor het erfrecht van de langstle-
vende echtgenoot", WPNR 6055 (1992), p. 493-496.

Creemers, J.H.F.J.

J.H.F. Cremers, Prioriteitsaandelen, Serie Monografieën vanwege het Van der Heijden-instituut (5), Deventer: Kluwer 1971.

Dooren, L.G.F.M. van

L.G.F.M. van Dooren, "Geven" of "voorbehouden" van vruchtgebruik op onroe300. 
Dortmiond, P.J.

P.J. Dortmond, Enige beschouwingen rondom andelen. Storting; blokkering; verkrijging bij juridische fusie (diss. KUN), Serie Monografieën vanwege het Van der Heijden-instituut (31), Deventer: Kluwer 1989.

Drielsma, H.A.

H.A. Drielsma, 'Reversibiliteit wan vruchtgebruik krachtens derdenbeding (II, slot)', WPNR 4419 (1955), p. 465-467.

Ebben, E.W.J.

E.W.J. Ebben, De positie van de langstlevende echtgenoot en de kinderen in het nieuwe erfrecht (diss. Amsterdan VU), Amsterdam: Boom Juridische Uitgevers 2000.

E.W. Ebben, 'De ene bevoegdheid is de andere niet (Reactie)', WPNR 6480 (2002), p. 237-239.

\section{Emmerig, $\mathbb{B}$.}

B. Emmerig, 'Regeling van geschillen tussen aandeelhouders", AA 1988, p. 318324.

Fesevur, J.E.

J.E. Fesevur, 'Texeira revisited', NTBR 2001/10, p. 503-507.

J.E. Fesevur, 'Redelijkheid en billijkheid in het goederenrecht; de rechter reeds lang op het goede spoor', WNPR 6472 (2002), p. 29-39.

Fikkers, H.A.G.

H.A.G. Fikkers, 'De kip-of-ei kwestie: geen kippedrukte. Over de zakelijke gebonden wil, zaaksbegrip, zaaksworming, vruchttrekking en kosten tot behoud', NJB $1996 / 8$, p. 274-279.

Frielink, $\mathrm{K}$.

$\mathrm{K}$. Frielink, 'Open bewaargeving van effecten en giraal effectenverkeer (1)', WPNR 5944 (1990), p. 19-24.

K. Frielink, 'Open bewaargeving van effecten en giraal effectenverkeer (II, slot)', WPNR 5945 (1990), p. 35-38.

K. Frielink, "Vruchtgebruik en aandelen", TVVS 1992/6, p. 139-1.42.

K. Frielink, "Diwidendrechten van certificaathouders", $V \& O$ 1997/7-8, p. 85-86. 


\section{Goulen, M.S. van}

M.S. van Gaalen, Vruchtgebruik (diss: Amsterdam WU), Amsterdam: 2001.

\section{Gorter en Nakad}

D. Gorter en H. Nakad, 'Zorgplicht en vruchtgebruik van effecten; effecten vruchtgebruik op de zorgplicht", TwE 2004/11, p. 256-260.

\section{Goudsmit, If}

J.J. Goudsmit, "Een hiaat in de blokkeringsregeling van de bw", TVTS 1978-1, 11-14.

J.J: Goudsmit; 'Reactie', TVWS 1978-3, p. 103-104.

Grinten, W.C.L. van der

W.C.L. van der Grinten, 'Stromannen en kunststro', in: H.J.M.N. Honée, S.C.J Kortmann, M.J.A.V. Mourik, A.VM. Struycken en D.W.F Verkade (red.), $V_{6}$ Vennootschappelijk Belang. Zwolle: W.E.J. Tjeenk-Willink 1988, p. 51-61.

W.C.L. van der Grinten, "Minderheidsrechten", $N V 70$ (1992), p. $271-275$.

W.C.L. van der Grinten, 'L. Groefsema. Bevoegd beschikken over anderma! recht', $N J B 1993 / 30$, p. $1087-1088$.

van der Grinten en Treurniet

W.C.L. van der Grinten \& W.C. Treurniet, Certificering van onroerend goc Praeadvies uitgebracht voor de Broederschap der Notarissen, Den Haag: 1964.

Groefsema, L.

L. Groefsema, Bevoegd beschikken over andermans recht (diss. RUG), Devente Kluwer 1993.

\section{Groenland en Portengen}

1.C.P. Groenland \& H.J. Portengen, Bewilliging van certificaten van aandelen WPNR 6559 (2003), p. 947.952.

Haentjens, $M$.

M. Haentens; 'Privaatrechtelijke aspecten van giraal effectenverkeer', $W P N$. 6582 (2004), p. 472-481.

M. Haentjens, 'Naschrift. Zicht op onduidelijkheid; over aanspraak, overdracht e vertegenwoordiging in de Wge', WPNR 6602 (2004), p. 988-990. 
Handboek Nieuw Erfrecht (2002)

MJ.A. van Mourik, L.C.A. Verstappen, B.M.E.M. Schols, F.WJM Schols en

B.C.M. Waaijer, Handboek Nienw Erfrecht. Deventer: Kluwer 2002.

Handboek NV/BV (1992)

W.C.L. van der Grinten, H.J.M.N. Honée en Th.C.M. Hendriks-Jansen, Vam der Heijden's Handboek woor de waamlozen en de besloten vemootschap. Zwolle: W.E.J. Tjeenk-Willink 1992.

Hamers, J.J.A.

J.J.A. Hamers, Verpanding van aandelen en de beslotenheid van kapitaalvemootschappen (diss. RL), Deventer: Kluwer 1996.

Hammerstein, A.

A. Hammerstein, Eigenlijke en oneigenlijke zaaksvervanging (diss: KUN), Zwolle: W.E.J. Tjeenk Willink 1977.

Hayton, D.J.

D.J. Hayton, "Trusts", in: D.J. Hayton, et al. (red.), Verrouwd met de trust. Trust and trust-like arrangements. Serie Onderneming en recht. Deel 5, Deventer: W.E.J. Tjeenk Willink 1996, p. 3-65.

Hoek, M.P. van den

M.P. van den Hoek, Dematerialisatie an anonimiteit. Reactie op het artikel van Verjans WPNR 6495 (2002)', WPNR 6504 (2002), p. 675-677.

M.P. van den Hoek, 'De toekomst van de overdrachtsparadigma', Ondernemingsrecht $2003 / 12$, p. $464-466$.

M.P. van den Hoek, "Wge moet af van "mede-eigendom", WPNR 6536 (2003), p. $432-438$.

M.P. van den Hoek, 'Waar zijn gedematerialiseerde aandelen?' WPNR 6567 (2004), p. 147-156.

Houben, K.M.F.J.

K.M.F.J. Houben, "Enkele testamentaire beschikkingen in de overgangsfase", WPNR 6504 (2002), p. 667-674.

Huijgen, W.G.

W.G. Huijgen, 'Economische eigendom van aandelen: het vennootschapsrecht opzij gezet", WPNR 6166 (1995), p. 63-68. 
W.G. Huijgen, Economische eigendom. Studiepockets Privaatrecht. 50, Zwolle: W.E.J Tjeenk Willink 1995.

Huurne, G.M. ter

G.M. ter Huurne, Nienwe regels voor de levering van aandelen op naam (diss. $R U G)$, Uitgave vanwege het Instituut voor Ondernemingsrecht Rijksuniversiteit Groningen (20), Deventer: Kluwer 1994.

Ingh, F.JP van den

F.J.P. van den Ingh, Certificering en certificaat van aandeel bij de besloten vennootschap (diss. KUN), Deventer: Kluwer 1991.

F.J.P. van den Ingh, 'Het stemgedrag van aandeelhouders', in: J.B. Huizink, J.B. Wezeman en J. Winter (red), A-T-D. Opstellen aangeboden aan Prof. mr. $P$ van Schilfgaarde, Deventer: Kluwer 2000, p. 203-213.

F.J.P. van den Ingh, 'Bewilligde of niet-bewilligde certificaten (Reactie)', WPNR 6478 (2002), p. 191-192.

F.I.P. van den Ingh; 'Met medewerking uitgegeven certificaten', Stichting, Véreniging \& Vennootschap 2003/5, p. 181-185.

Keijser, T.R.M.P.

TR.M.P. Keijser, "De rechtspositie van de pandgever op de schopstoel. Het 'gebruiksrecht' van de Collateral Richtlijn beschouwd naar Nederlands en Duits recht', NTBR 2003/8, p. 432-442.

Klaassen-Luijten-Meijer (2002)

E.A.A. Luijten \& W.R. Meijer, Klaassen-Eggens' Huwelijksgoederen- en erfrecht. Tweede gedeelte. Erfrecht. Deventer: Kluwer 2002.

Kleijn, W.M.

W.M. Kleijn, Vruchtgebruik: Monografieën Nieuw BW-B10, Deventer: Kluwer 1990.

WM. Kleijn, 'Zaaksvervanging of vergoeding; nog steeds en weer aktueel', WPNR 6247 (1996), p. 869:872.

Koelemeijer, $\mathrm{M}$.

M. Koelemeijer, Redelijkheid en billijkheid in kapitaalvennootsclaappen (diss. RL), Deventer: Kluwer 1999. 
Koppenol-Laforce, M.E.

M.E. Koppenol-Laforce, Het Haagse tristverdrag (diss. EU), Deventer: Kluwer 1997.

Kraan, C.A.

C.A. Kraan, 'Schenking of lastgeving? Of geen van beide?' WPNR 5730 (1985), p. $179-181$.

C.A. Kraan, 'Erfrecht en wruchtgebruik', in: T.J. Mellema-Kranenburg, C.A. Kraan en I.J.F.A.v. Vijfeijken (red.), Vruchtgebruik. Preadvies Koninklijke Notariële Beroepsorganisatie, Lelystad: Kluwer 1999, p. 65-139.

Langemeijer, G.E.

G.E. Langemeijer, Zaaksvervanging (diss. RUL), Vlaardingen: Dorsman en Ode 1927.

Leijten, A.F.J.A.

A.F.J.A. Leijten, "Tien jaar uitkoop- en geschillenregeling (I)", Ondernemingsrecht 1999/8, p. 204-209.

A.F.J.A. Leijten, 'Twee jaar witkoop- en geschillenregeling: rechtspraak- en literatuuroverzicht 2001-2002', in: G. van Solinge en M. Holtzer (red.), Geschriften vanwege de vereniging Corporate Litigation 2002-2003 Deventer: Kluwer 2003, p. 51-75.

Losbl. Rp. (auteur)

Rechtspersonen, Losbladige Kluwer-uitgave, C.A. Boukema (red.)

Lubbers, A.G.

A.G. Lubbers, Vruchtgebruik naar huidig en toekomstig recht. Prae-advies Broederschap der Notarissen, 1959.

Luijten, E.A.A.

E.A.A. Luijten, 'Een nieuw geluid', WPNR 6034 (1992), p. 71-72.

E.A.A. Luijten, 'De OBV "si (non) voluero"?' WPNR 6231 (1996), p. $521-523$.

Luijten, van Mourik en Commissie Erfrecht

E.A.A. Luijten, M.J.A. van Mourik en Commissie Erfrecht, 'Het langstlevende erfrecht', WPNR 6260 (1997), p. 291-303. 
Luijten en Rombach

E.A.A. Luijten \& J. Rombach, De ouderlijke boedelverdeling volgens de art. 1167 e.v. BW. Praeadviezen wit gebracht voor de Broederschap der CandidaatNotarissen. Den Haag: 1958.

Maanen, G.E. van

G.E. van Maanen, Eigendomsschingbewegingen. Juridische, historische en politiek-filosofische opmerkingen over eigendom in huidig en komend recht, Nijmegen: Ars Aequi Libri 1987.

Maatman, R.H.

R.H. Maatman, "Beleggen volgens de prudent person-regel', Ondernemingsrecht $2003 / 17$, p: $645-652$.

Maeijer, JMM.

J.M.M. Maeijer, 'Vertegenwoordiging en volmacht', in: R.J.C. van Helden, et al. (red.), Problemen rondom de Algemene Vergadering. Serie Monografieën vanwege het Van der Heijden-institwu (45), Deventer: Kluwer 1994, p. 63-79.

J.M. Maeijer, Economische eigendom van aandelen; het vennootschapsrecht wijkt niet", WPNR 6182 (1995), p. 337-339.

Meijer, S.YTh.

S.Y.Th. Meijer, Middellijke Vertegenwoordiging (diss. VU), 1999.

Meijer, W.R.

W.R. Meijer, Effectenbewaring (diss. KUN), 1974.

W.R. Meijer, 'De Visser-Harms, nog steeds actueel?' in: P.H.M. Gerver, J.G. Kuijl, A.M.H. Pleysier en R.T.G. Verstraaten (red), Heden verschenen woor wij. Soonsbundel, Arnhem: Gouda Quint 1995, p. 105-116.

Meinema, $\mathrm{M}$.

F.I. P. van den Ingh, "Met medewerking uitgegeven certificaten', Stichting. Vereniging \& Vennootschap 2003/5, p. 181-185.

Mellema-Kranenburg, T.J.

T.J. Mellema-Kranenburg, 'Vruchtgebruik algemeen', in: T.J. Mellema-Kranenburg, C.A. Kraan en I.J.F... Vijfeijken (red), Vruchtgebruik. Preadvies Koninklijke Notarièle Beroepsorganisatie, Lelystad: Klinwer 1999, p. 15-64. 
Milio, J.M.

JM. Milo, 'Principles of European Trust Law (book review)', ERPL 2000/3, p. $533-542$.

Milo en Smits

J.M. Milo \& J.M. Smits, Trusts in Mixed Legal Systems: A Challenge to Comparitive Trust Law', ERPL 2000/3, p. 421-426.

Molenaar, F

F. Molenaar, Pandrecht. Monografieën Nieuw BW-B 12a, Deventer: Kluwer 1991.

de Monchy en Timmerman.

C.W. de Monchy \& L. Timmerman, De nieuwe algemene bepalingen van Boek 2 BW. Preadvies van de Vereeniging 'Handelsrecht", Zwolle: W.E.J. Tjeenk Willink 1991.

Mourik, M.J.A. van

M.J.A. van Mourik, De Eenmans-BV. Civielrechtelijke en fiscaalrechtelijke beschouwingen. Ars Notariatus XX, Deventer: Kluwer 1980.

M.J.A. van Mourik, 'Economische eigendom en vennootschaprecht.' in: H.C.F. Schoordijk (red.), Economische eigendom $16^{e}$ Landelijk Nolarieel Studentencongres. Ars Notariatus $X X T$, Leiden: Kluwer 1981, p. 53-69.

M.J.A. van Mourik, 'De meeslepende avonturen van de langstlevende echtgenoot (I)", NJB' 1982/1, p. 1-8.

M.J.A. van Mourik, 'De meeslepende avonturen van de langstlevende echtgenoot (II) , NJB $1982 / 2$, p. 33-46.

M.J.A. van Mourik, 'De meeslepende avonturen van de langstlevende echtgenoot (III), N/B 1991/31, p. 1251-1258.

M.I.A. van Mourik, 'Aandeelhouderschap en huwelijksgemeenschap', NW 61 (1983), p. $125-129$.

M.I.A. van Mourik, 'Goederen op naam van de andere echtgenoot; lastgeving', WPNR 5702 (1984), p. 380-382.

M.J.A. van Mourik, "Schoordijk en Modelnuis Nolly", WPNR 5712 (1984), p. 571575 .

M.J.A. van Mourik, "Naschrift bij Kraan WPNR 5730 (1985)", WPNR 5730 (1985), p. 182-183. 
M.J.A. van Mourik, "Versterferfrecht en verzorging (Reactie op bijdrage Zwanikken WPNR 6169)', WPNR 6170 (1995), p. 146-147.

van Mourik, Verstappen en Schols

M.J.A. van Mourik, L.C.A. Verstappen en Schols F.W.J.M., "Langstlevende-testamenten en huwelijkse voorwaarden', WPNR 6218 (1996), p. 245-248.

Nieskens-Isphording, B.W.M.

B.W.M. Nieskens-Isphording, "Boekbespreking "Vruchtgebruik" door prof.mr. W.M. Kleijn, 1990' WPNR 6081 (1993), p. 134-136.

B.W.M. Nieskens-Isphording, 'Praktijkgerichte evaluatie van het vruchtgebruik leidt tot vraag naar meer maatwerk”, WPNR 6368 (1999), p. 617-621.

Nieuwenhuis, J.H.

J.H. Nieuwenhuis, Uit de ban van hier en nu. Inaugurele rede, Deventer: Klluwer 1980

Nolet, JV.

J.V. Nolet, 'Vruchtgebruik en pandrecht op aandelen', WPNR 5352 (1976), p. 366368.

van Olffen, Buijn en Simonis

M. van Olffen, F.K. Buijn en P.H.M. Simonis, Splitsing van ondernemingen. Den Haag: Boom Juridische Uitgevers 2004.

Perrick, $S$.

S. Perrick, 'De aandelen in een N.V. of B.V. en de langstlevende echtgenoot als vruclitgebruiker volgens het wetsontwerp tot wijziging van Boek 4 Nieuw Burgerlijk Wetboek', $N V 60$ (1982), p. 140-145.

S. Perrick, "Een erflater mag aan een ouderlijke boedelverdeling een voorwaarde verbinden', WPNR 6214 (1996), p. 165-167

\section{Pitlo/Van der Burght (1997)}

Gr. van der Burght, Pitlo. Het Nederlands burgerlijk recht. Deel 5. Erfrecht. Deventer: Gouda Quint 1997.

Pitlo/Löwensteyn-Raaijmakers (1994)

F.J.W. Löwensteyn \& M.J.G.C. Raaijmakers, Pitlo. Het Nederlands burgerlijk recht. Deel 2. Rechtspersonenrecht. Deventer: Gouda Quint 1994. 
Pitlo/Raaijmakers (2000)

M.J.G.C. Raaijmakers, pitlo. Het Nederlands burgerlijk recht, Deel 2. Vennootschaps- en rechtspersonenrecht. Deventer: Gouda Quint 2000.

Pitlo/Reehuis-Heisterkamp (2001)

W.H.M. Reehuis, A.H.T. Heisterkamp, G.E. van Maanen en G.T. de Jong, Pitlo. Het Nederlands burgerlijk recht. Deel 3. Goederenrecht. Deventer: Gouda Quint 2001.

Pleysier, A.J.H.

A.J.H. Pleysier, 'Over het behoud van beperkte zakelijke rechten (I)', WPNR 5509 (1980), p. 181-183.

A.J.H. Pleysier, "Over het behoud van beperkte zakelijke rechten in het nieuwe Burgerlijk Wethoek', WPNR 5530 (1980), p. 598-599.

Ploeg, P.W. van der

P.W. van der Ploeg, "Le mort saisit le vif", WPNR 5290 (1975), p. 17-22.

Rank, W.A.K.

W.A.K. Rank, "Bewaring en administratie van effecten volgens VABEF I en VABEF II', in: W.A.K. Rank, E.M. van Ardenne-Stachiw en Ch. W. le Rûtte (red.), Bewaring en eigendom van effecten. Preadvies voor de Vereniging van Effectenrecht. Serie Monografieën vanwege het Van der Heijden-instituut (55), Deventer: Kluwer 1997, p. 1-77.

Rank-Berenschot, E.B.

E.B. Rank-Berenschot, Over de scheidslijn tussen goederen- en verbintenissenrecht (diss. RUL), Deventer: Kluwer 1992.

E.B. Rank-Berenschot, 'L. Groefsema, Bevoegd beschikken over andermans recht”, WNPR 6160 (1994), p. 841-843.

E.B. Rank-Berenschot, 'Overdracht en toebehoren onder tijdsbepaling', in: R.C.S.I. Grotius (red.), Van Beheering. Goederenrechtelijke beschouwingen, Deventer: Gouda Quint 1998, p. 149-162.

E.B. Rank-Berenschot, 'Het Wge-aandeel: een recht op naam van eigen aard', in: S.C.J.J. Kortmann, W.A.K. Rank, M.H.E. Rongen, G. van Solinge en H.L.E. Verhagen (red.), Onderneming en effecten. Serie Onderneming en Recht. Deel 13, Deventer: WE.J. Tjeenk Willink 1998, p. 149-167. 
E.B. Rank-Berenschot, Bezit. Monografieen Nieuw BW-B7, Deventer: Klwwer 2001.

\section{Reinhartz, B.E.}

B.E. Reinhartz, 'Uitbreiding van de beschikkingsbevoegdheid van een vruchtgebruiker', WPNR 6455 (2001), p. 739-743

Rijn wan Alkernade, J van

J. van Rijn van Alkemade, 'Yes, the Dutch can tame the trust! (I)', WPNR 6317 (1998), p. 361-368.

J. van Rijn van Alkemade, 'Yes, the Dutch can tame the trust!(II, slot)', WPNR $6318(1998)$, p. 379-387.

Rogmans, B.G.P.

B.G.P. Rogmans, Verkeersopvattingen. Monografieën Nieuw BW A-20, Deventer: Kluwer 1999.

Rossel, H.J.

H.J. Rossel, "De verkeersopvatting', in: T. Harthief, A.H.T. Heisterkamp en W.H.M. Reehuis (red.), CJHB. Brunher-Bundel, Deventer: Kluwer 1994, p. $335-$ 344.

Schaick, A.C. van

A.C. van Schaick, "Verkeersopvattingen in het goederenrecht", in: S.E. Bartels en J.M. Milo (red.), Open normen in het goederenrecht, Den Haag: Boom Juridische Uitgevers 2000, p. 79-90.

Schilfgaarde, P. van

P. van Schilfgaarde, 'Tegenstrijdig belang in het vennootschapsrecht', in: L. Timmerman, et al. (red), De dubbelrol in het vemootschapsrecht: aan welke beperkingen onderwerpt het vennootschapsrecht het vervullen van dubbelrollen? Uitgave vanwege het Instituut voor Ondernemingstecht Rijksuniversiteit Groningen (16), Deventer: Groningen 1993, p. 23-32.

Schim, B.F.L.M.

B.F.M. Schim, 'Girale levering als girale betaling; over artikelen 17 en $4 \mathrm{l}$ Wge en artikel 3:84", in: S.C.Ju. Kortmann, W.A.K. Rank, M.H.E. Rongen, G. van Solinge en H.L.E. Verhagen (red.), Onderneming en 10 jaar nieuw burgerlijk recht. Sevie Onderneming en Recht. Deel 24, Deventer: Kluwer 2002, p. 193-209.

B.FL.M. Schim, 'Recensie "Effectengiro-recht in beweging", $N T B R 2004 / 8, \mathrm{p}$. 383-392. 
B.F.L.M. Schim, 'Verpanding van girale effecten', Ondernemingsrechi 2004-11, p. $418-424$.

Schols, B.M.E.M.

B.M.E.M. Schols, 'De voorwaardelijke OBV onvoorwaardelijk ofwel de weg naar vrijheid geopend", WPPR 6308 (1998), p. 223-225.

B.M.E.M. Schols, 'Hoe super is het superturbotestament?' WPNR 6362 (1999), p. 471-474.

\section{Schoordijk, H.C.F.}

H.C.F. Schoordijk, 'Enige aantekeningen n.a.v. het voorontwerp van wet betreffende het giraal effectenverkeer (1)', WPNR 5316 (1975), p. 629-638.

H.C.F. Schoordijk, "Economische eigendom, vooral in het licht van beslag-, executie- en bewijsrecht.' in: H.C.F. Schoordijk (red.), Economische eigendom $16^{\circ}$ Landelijk Notarieel Studentencongres. Ars Notariatus XXTV, Leiden: Kluwer 1981, p. 1-18.

H.C.F. Schoordijk, "Naschrift bij Kraan WPNR 5730 (1985)", WPNR 5730 (1985), p. 181-182.

H.C.F. Schoordijk, "Van Mourik en Modehuis Nolly", WPNR 5712 (1985), p. $565-$ 571 .

Schwarz, C.A.

C.A. Schwarz, 'Overdracht van aandeelhouderschap en art. 195 Boek 2 BW', $N V$ 61 (1983), p. 222-224.

C.A. Schwarz; Blokkering van aandelen (diss. RUL), Serie Monografieën vanwege het Van der Heijden-instituut (27), Deventer: Kluwer 1986.

C.A. Schwarz, 'Enkele vragen bij certificering van aandelen', TVVS 1992/1, p. 611.

C.A. Schwarz, 'Certificering als beschermingsconstructie; bruikbaarheid in een veranderend tijdsgewricht', $T V O B 2004 / 5$, p. 220-225.

Serière, V.P.G. de

V.P.G de Serière, 'Stille cessie mogelijk gemaakt: goed nieuws voor securitisation en factoring transacties?' Ondernemingsrecht 2003/10, p. 376-378 
Slagter, W.J.

W.I. Slagter, Juridische en economische eigendom. Diës-rede NEH Rotterdam, Deventer: Kluwer 1968.

W.J. Slagter, 'Inwoering van een geschillenregeling in besloten vennootschappen en bepaalde naamloze vennootschappen', TVVS 1985, p. 126-128.

W.J. Slagter, "Vordering tot uitkering van dividend. Noot uitspraak 'Uniwest Group BV", TVVS 1991, p. 160-162.

W.J. Slagter, 'Eigendom en pseudo-eigendom', in: E.H. Hondius, et al. (red.), Quod Licet. Kleijm-bundel, Deventer: Kluwer 1992, p. 357-374.

W.J. Slagter, 'Rechtspraak vennootschapsrecht. Geschillenregeling', TVVS $1996 / 12$, p. $350-353$.

W.J. Slagter, 'De lidmaatschapsverhouding als grondslag van het rechtspersonenrecht', Ondernemingsrecht 2004/11, p. 424-428.

Snijders, W.

W. Snijders, 'Wilsrechten, in het algemeen en in het nieuwe erfrecht (I)', WPNR 6365 (1999), p. $558-565$.

W. Snijders, 'Wilsrechten, in het algemeen en in het nieuwe erfrecht (II)', WPNR 6566 (1999), p. 583-589.

W. Snijders, 'Wilsrechten, in het algemeen en in het nieuwe erfrecht (III)', WPNR 6367 (1999), p. 601-608.

W. Snijders, 'Ongeregeldheden in het vermogensrecht (I)', WPNR 6607 (2005), p. 79-85.

W. Snijders, 'Ongeregeldheden in het vermogensrecht (II, slot)', WPNR 6608 (2005), p. 94-102.

Snijders-Rank-Berenschot (1996)

H.J. Snijders \& E.B. Rank-Berenschot, Studiereeks Burgerlijk Recht. Goederenrecht. Deventer: Kluwer 1996.

Snijders-Rank-Berenschot (2001)

H.J. Snijders \& E.B. Rank-Berenschot, Studiereeks Burgerlijk Recht. Goederenrecht. Deventer: Kluwer 2001. 
Solinge, A.G. van

A.G. van Solinge, 'Erfrecht en vennootschapsrecht', in: J.M.M. Maejjer, P.W. van der Ploeg jr. en A.G. van Solinge (red.), Recht zo die gaat. Opstellen aangeboden aan mr. P.W. van der Ploeg, Zwolle: W.J.J. Tjeenk Willink 1976, p. 143-166.

Solinge, G. van

G. van Solinge, Grensoverschrijdende juridische fusie (diss. Amsterdam VU), Amsterdam: Kluwer 1994

G. van Solinge, 'Stemvolmacht aan de pandhouder zonder stemrecht', in: S.C.JJ. Kortmann, N.E.D. Faber en J.A.M. Strens-Meulemeester (red.), Vertegenwoordiging en tussempersoon. Serie Onderneming en Recht. Deel 17, Deventer: W.E.I. Tjeenk Willink 1999, p. 117-145.

Spruit, J.E.

J.E. Spruit, Cunabula iuris Elementen van het Romeinse privaatrecht, Deventer: Kluwer 2003.

Stein, P.A.

P.A. Stein, "Modehuis Nolly-arrest", Ars Aequi 1976, p. 759-765.

P.A. Stein, 'L. Groefsema, Bevoegd beschikken over andermans recht (recensie)', RM Themis 1994-5, p. 243-247.

Stok, E.B. van der

E.B. van der Stok, 'Het vruchtgebruik-tegen-inbreng-blote-eigendom (turbo)testament', WFR 6227 (1996), p. 125-132.

Struyken, A.V.M.

A.V.M. Struycken, "Fiducia cum marito en middellijke vertegenwoordging door de echtgenoot bij de verwerving van onroerend goed', WPNR 5370 (1976), p. 738 740 .

Timmerman, L.

L. Timmerman, in: C.W. Monchy en L. Timmerman (red.), De nieuwe algemene bepalingen van Boek 2 BW. Preadvies van de Vereeniging 'Handelsrecht', Zwolle: W.E.J. Tjeenk Willink 1991, p.

Uniken Venema, C.Æ.

C..E. Uniken Venema, Effectengiro-recht in beweging. Center for Company Law, Den Haag: Boom Juridische Uitgevers 2003. 
Uniken Venema en Eisma

C.A. Uniken Venema \& S.E. Eisma, Eigendom ten vitel wan beheer naw komend rechi, Zwolle. WE J. Tjeenk Willink 1990.

Velten; A.A. van

A A van Velten, Economische eigendom in en om het zakenrecht; een analyse." in: H.C.F. Schoordijk (red.), Economische eigendom $16^{\circ}$ Landelijk Notarieel Studentencongres. Ars Notariatus XXTV, Leiden: Kluwer 1981, p. 19-28."

A.A. van Velten, Kopers en economische eigenats van onroerend goed (diss. Amsterdam UvA), Amsterdam: Kluwer 1982.

Verhagen, H.L.E.

H.L.E. Verhagen, 'Het Haagse Trustverdrag', in: D.J. Hayton, et al. (red.), Vertround met de trust. Trust and trust-like arrangements. Serie Onderneming en recht: Deel 5, Deventer: W.E.J. Tjeenk Willink 1996, p. 69-123.

Verjans, R.L.S.

R.L.S. Verjans, 'Dematerialisatie van toonder-effecten", WPNR 6495 (2002), p. 465-471.

Verstappen, L.C.A.

L.C.A. Verstappen, 'Het voorlopig Verslag van de Eerste Kamer op het wetsvoorstel Erfrecht', WPNR 6349 (1999), p. 189-194.

Visser, K.I.J.

K.I.J. Visser, Zeggenschapsrechien vaw houders van een recht van pand of wruchtgebruik op aandelen op naam (diss. RUG), Uitgave vanwege het Institunt voor Ondernemingsrecht Rijksuniversiteit Groningen (48), Deventer: Kluwer 2004.

Voogd, R.P.

R.P. Voogd, Statutaire beschermingsmiddelen bij beursvennootschappen (diss. KUN), Nijmegen: 1989.

Waal, MiJ. de

M.J. de Waal, "The Uniformity of Ownership, Numerus Clausus and the Reception of the Trust Into South African Law", ERPL 2000/3, p. 439-452.

Westbroek, W.

W. Westbroek, 'Uitkoopregeling en geschillenregeling (I)', WPNR 5759 (1985), p. 709-715. 
W. Westbroek, "De geschillenregeling", in: J.M.P. Hermans (red), Uikoop en geschillenregeling Arnhem: Couda Quint 1991, p. 15-31.

Wichers, J.E.

J.E. Wichers, Natrekking, vernenging en zalksworming. Opmerkingen bij de algemene regeling voor roerende zaken in het Burgerlijk Wetboek (diss. RUG), Groningen: 2002.

Winter, J.W.

I.W. Winter, 'Recht op dividend (Uniwest Group BV)', WPNR 6001 (199l), p. 246-248.

IJsselmuiden, Th. S.

Th.S. IJsselmuiden, 'Noot bij OK 4 mei 1995 ('Kerstens')', TWVS 1995/7, p. 196197.

Zwanikken, G.G.

G.G. Zwanikken, "Modernisering van het verzorgingsbegrip", WPNR 6169 (1995), p. 121-122.

Zwitser, R.

R. Zwitser, 'Accessie hier en in het buitenland (I)', WPNR 6210 (1996), p. 87-91.

\section{Zuid-Afrika}

Honnore's Trusts (2002)

E. Cameron, M.. de Waal, B. Wunsch, P. Sallomon en E. Kahn, Honoré's South African Law of Trusts, Lansdowne: JUTA Law 2002.

Plessis, L.M. du

L.M. du Plessis, An Introducrion to Law, Capetown: JUTA \& Co. Lid 1999.

Succession Law (2001)

M.M. Corbett, G. Hofmeyr en E. Kahn, The Law of Succession in South Africa, Lansdowne: JUTA Law 2001.

Swanepoel, H.L.

H.L. Swanepoel, "Oor stigting, trust, fideicommissum, madus en beding ten behoewe van 'n derde', THRHR 1956, p. 102-116. 


\section{Waal, M.J. de}

M.J. de Waal, 'Die strekwijdte van trustees se beleggingsbewoegdheid', TSAR $1999 / 2$, p. 370-378.

M.J. de Waal, 'The core elements of the trust: aspects of the English, Scottish and South African trusts compared', SALJ 2000/3, p. 548-571. 


\section{TREFWOORDENREGISTER}

Er wordt verwezen naar paragrafen. Cursief gedrukte nummers verwijzen naar paragrafen waiarin het betreffende trefwoord meer uitwoerig wordt behandeld.

\section{Aandeel}

- aan toonder

- in de WGE

- op naam

bestemming van een -

prioriteits-

rechtskarakter van

vrucht van

Aandeelhouder

-schap

-sregister

Aandelen.

voorbehouden vruchtgebruik op -

Ab intestaat erfrecht

Beheersbevoegdheid

Beheren

Beleggingsplicht

Beleggingsrekening

Beschikken

- bevoegdelijk

- over een goed van een derde

- onbevoegdelijk

Beschikkingsbevoegdheid

Beslotenheid

Bestemining

- van een aandeel

- van een goed

verandering van

Bewaargeving

geïndividualiseerde -

niet-geindividualiseerde -

Bezit-sverschaffing

Blokkeringsregeling

algemeen
4.2 .1 .4 .5

zie deelgerechtigdhend

$4.2 .1 .4 .3 ., 4.4$.

zie bestemmingpreferent $-4.4 .1,5.2 .4$.

4.4.1., 5.2.4.

$5.2,5.3 .1,5.4$

5.5.1.

$3.4 .4,5,2$

4.3.3.

3.4.4.

zie versterferfinecht

2.4.3., 5.5.2.2.

zie beheersbevoegdheid

2.5.2.,

2.6.3.1, 5.5.2.2.

2.4 .4

2.6 .2 .

2.4.5.

2.6.6.

2.4.4.3., 2.4.5., 2.7, 3.3.1., 3.4.3., 3.7.3.4., $5.5 .2 .2,5.5 .3 .5 .5 .4$.

3.7.1., 3.7.3.4., 3.7.4.2., 5.2.4., 5.3.2., 6.2 .1 .1

5.3.

2.4.4.2.

2.4.4.2., 5.3.2.

4.5 .4 .

4.5.4.1.

4.5.4.2.

2.2.1.4., 2.6.3.1., 4.5.3.

$3.5 .5 ., 3.7 .2 ., 3.7 .3 ., 4.3 .4 ., 4.4 .1 ., 4.4 .2$, 6.2 .1 . 
erfrechtelijke -

Boedelbeschrijuing

Certificaathoudersirechten

Cessie

Dewlgerechtgdheid

Derdenbescheming

Directe leer

- en substitutie

Dividend

Doorleveringsleer

Economisch eigendom

Erkenning

Fidel-commis (de residuo)

Gebruilk recht van -

Geschillenregeling

Girodepot

'Goed vruchtgebruikerschap'

Instandhoudingsverplichting.

Jundische fusie

Juridische splitsing

Kring van antikel 2.8

Leer van de directe verkrijging

Legaat

Legitieme portie

Lidmaatschapsrechten

Lidmaatschapsverhouding

Making onder tijdsbepailng

Making onder voonwaarde

Normatieve verkrijgingsleer

Ouderlijke boedelverdeling

Saisine

Stemrecht

Stieffamilie-gevaar

Substitutie

Terhandstelling

Testamentair erfrecht

Testamentaire last

Testeervrijheid

"trust"

Uiterste will
3.7.

$2.5 .2,4.5 .3$.

$4.5 .5 .5 ., 6.2 .4 ., 6.6 .4 ., 6.6 .43$.

4.3.3.1.

$4.5 .1,4.5 .5 .4$.

$2.2 .13,4.5 .42$.

2.6.3.

$4.3 .3 .1 ., 4.5 .3,5.2 .2$.

2.6.3. 1 .

7.2 .

4.3.1., 4.3.3.

zie voormaardelijke making

$2.4 .2,5.5 .2$

$6.1 ., 6.4$.

4.5 .5 .1 .

2.5.1., 5.5.2.2., 5.5.3.2.

2.6.1.

6.6 .

zie juridische fusie

6.3.

zie "directe leer"

3.3.1.2., 3.5.2., 3.7.3.3.

3.3.1.2.

4.3.1., 5.2.4., 6.2.2., 6.6.2., 6.6.4., 6.7.

$5.2 .4 ., 5.2 .6 ., 6.7$.

zie voorwaardelike making

zie voorwardelije making

zie "directe leer"

3.2., 3.3.1

3.7 .4 .

$2.5 .1 ., 3.2 .2 ., 3.5 .5 ., 3.7 .2 ., 3.7 .3 .4$.

$4.5 .3 ., 4.5 .5 .5 ., 5.2 .5 ., 5.5 .2 .1 ., 6.2$,

$6.4 .4 ., 6.6 .4 .2$

$3.3 .1 ., 3.3 .1 .1 ., 3.4 ., 3.4 .2$.

$2.6 ., 3.4 .3 ., 4.5 .5 .4,5.5 .4 .2 ., 6.6 .2$.

4.5 .3 .

3.3.1.2., 3.7.3.

$3.3 .1 .2,3.5 .2$.

3.5 .1 .

7.4.

3.3.1.1. 


\begin{tabular}{|c|c|}
\hline Uitkoopregeling & $6.1,6.5$ \\
\hline $\begin{array}{l}\text { Uitstoting } \\
\text { Uing }\end{array}$ & 6.4 .2 \\
\hline Uittreding & 6.4 .3 \\
\hline$V A B E F$-systeem & $4.5 .1 ., 4.5 .4 .2$ \\
\hline Verbruik & \\
\hline $\begin{array}{l}\text { recht van - } \\
\text { Verjaring }\end{array}$ & $\begin{array}{l}2.4 .2 ., 5.5 .2 ., 5.5 .3 \\
20.3\end{array}$ \\
\hline $\begin{array}{l}\text { Verjaring } \\
\text { Verkeersopvatting }\end{array}$ & \\
\hline $\begin{array}{l}\text { Verkeersopvatting } \\
\text { - en bezit }\end{array}$ & 2.2 .1 .4 \\
\hline $\begin{array}{l}\text { - en bezit } \\
\text { - en vruchten }\end{array}$ & $\begin{array}{l}2.2 .1 .4 . \\
2.4 .1 ., 2.4 .1 .2,5.5 .1 .2,5.5 .1 .3 .\end{array}$ \\
\hline $\begin{array}{l}\text { - en vruchten } \\
\text { Vermenging }\end{array}$ & $\begin{array}{l}2.4 .1 ., 2.4 .1 .2,5.5 .1 .2,5.5 .1 .3 . \\
2.3 .2\end{array}$ \\
\hline $\begin{array}{l}\text { Vermenging } \\
\text { oneigenlijke - }\end{array}$ & $\begin{array}{l}2.3 .2 . \\
4.5 .1 ., 4.5 .4 .2 ., 4.5 .5 .2 .\end{array}$ \\
\hline $\begin{array}{l}\text { oneigenlijke - } \\
\text { Versterferfrecht }\end{array}$ & $\begin{array}{l}\text { 4.5.1., } 4.3 .4 .2 ., 4.5 .5 .2 . \\
\text { 3.3.1.1. }\end{array}$ \\
\hline Vervreemden & \\
\hline - en verteren & $2.4 .4 .4 ., 3.4 .3 ., 5.5 .3$ \\
\hline - naar bestemming & $2.4 .4 .2 ., 5.5 .3$ \\
\hline Vervreemdingsbevoegdheid & 3.5.5., 5.3.1. \\
\hline Verzameldepot & 4.5.5.1. \\
\hline Verzorgingsbehoefte & 3.5.3., 3.7.3.4., 5.5.3.3, 5.5.4.1. \\
\hline Voorwaardelijke making & $3.6 .3 ., 3.7 .3 .3$ \\
\hline Vruchten & \\
\hline afgesproken - & 2.4.1.3. \\
\hline burgerlijke - & $2.4 .1 .1 ., 2.1 .4 .4 ., 2.4 .1 .5 ., 5.5 .111$ \\
\hline natuurlijke - & 2.4.1.1. \\
\hline van andelen & zie Aandeel \\
\hline winstbesluit en - & 6.3 .2 \\
\hline Vruchtgebruik & \\
\hline certificering en - & 7.3 \\
\hline duur van - & 2.3 \\
\hline - en economisch eigendom & 7.2 .3 \\
\hline einde van & 2.3 .5 \\
\hline gezamenlijk - & 2.3 .2 \\
\hline legaat wan - & 3.2.2., 3.6.2., 5.5.1.2. \\
\hline oneigenlijke - & 5.5 .4 .2 \\
\hline ontstaan van - & 2.2. \\
\hline overdracht en overgang van - & 6.2 .1 .5 \\
\hline -testament & $3.1 ., 3.2 ., 3.2 .1$. \\
\hline verzorgings- & $3.3 .1 .2 ., 3.5 ., 3.7 .3 .1 ., 3.7 .3 .4,3.7 .4 .3$. \\
\hline vestiging van - & $2.2 .1 ., 4.2$ \\
\hline voorbehoud van - & $2.2 .2 ., 3.3 .1 .1 ., 3.4 .3 ., 3.7 .2,5.5 .3 .3$ \\
\hline Wettelijke verdeling & $3.3 .1 ., 3.3 .1 .1 ., 3.7 .2$ \\
\hline WGE & $4.2 .1 ., 4.4 .1 ., 4.5 .1$ \\
\hline Wilsrechten & $3.3 .1 .1,3.4 ., 3.4 .2,3.4 .4,6.2 .1 .3$ \\
\hline
\end{tabular}





\section{JURISPRUDENTIEREGISTER}

\section{Nederland}

Hoge Raad

30-11-1945

27-01-1956

NJ 1946,62 (De Visser/Harms)

3.2., 7.3.5.

23-01-1958

NJ 1956, 48 (Rolterdanse Droogdok Mij.)

6.3 .1 .

NJ 1958, 458 (Pierlot/Kreemer)

5.5.1.2., 5.5.1.3., 5.6 .

11-04-1958

NJ 1958, 302 (Schellens/Schellens)

3.7 .2 .

16-01-1959 NJ 1959, 355 (Swierenga)

2.5., 5.5.2.1.,

5.5.4.2.

$11-01-1963$

NJ 1964, 433 m.nt. GIS (Rubber Cultuwr Mij.)

6.3 .1 .

12-01-1968 No 1968, 274 m.nt. HD (Texeira de Mattos)

$4.5 .1 ., 4.5 .4 .2$

$15-07-1968$

NJ 1969, 101 m.nt. GJS (Wijsmuller)

6.2 .1 .

12-05-1972

NJ 1973, 53 (Meerzicht)

3.2 .

02-04-1976.

NJ 1976, 450 m.nt. WMK (Modehuis Nolly)

$2.6 .3 .1 ., 7.2 .3$

07-02-1979

NJ 1979, 551 m.nt. WMK (Voorbehoud

vruchtgebruik)

2.2 .2

16-03-1979

NJ 1980,600 m.nt. BW (Radio Holland)

2.4.1.3., 5.5.1.3.,

7.2.3.

16-03-1984 NJ 1984, 556 (Modehuis Nolly II)

2.6.3.1.

11-05-1985

NJ 1985, 374 m.nt. WMK (Verhoeven/Peters)

3.2.1.

09-07-1990

NJ 1991, 51 m.nt. Ma (Sltiis" BV)

6.3 .2 .1 .

NJ 1994, 436 m.nt. Ma(Venenigde Boothieden) $\quad 6.2 .1$.

$31-12-1993$

NJ 1996, 461 m.nt. WMK (Kas-Associatief

Drying Corp)

2.6.3.1.

07-12-1994

NJ 1995, 301 m.nt. Ma (Staatssecretaris/Erwen X)

09-12-1994

NJ 1995, 224 (Van Opstal/Van Miert)

5.5 .1 .2

24-03-1995

NJ 1996, $158 \mathrm{~m}$.nt. WMK (Hollander's/Coöp)

2.5 .3 .

09-01-1996

NJ 1998, 285 m.nt. WMK (MeesPierson/Ten Bos)

$17-01-1998$

BNB 1998, $112 \mathrm{c}$

2.4.1.1.

2.6.3.1., 5..5.2.2.,

7.2 .3 .

04-12-1998

N.J 1999, 549 m.nt. WMK (Potharst/Serrée)

3.2 .1 .

2.2.2. 
Hof Amsterdam (OK)

22-10-1992 NJ 1993, 411 (Van EykNootebos I)

6.4.2.1.

09-12-1993 NJ 1994, 296 ( Kan Eyk/Nootebos M)

6.4 .3 .

24-02-1994 NJ 1995, 354 (Peeters/Peeters)

6.4 .3 .

27-10-1994 NJ 1996, 167 (Muller/Muts)

6.4.2.1.

16-03-1995 JOR 1996,54 m.nt. vd lingh (Ramp/Lensen)

6.4 .3 .

15-09-1995 NJ 1995, 540 (Kerstens)

6.3 .2 .1 .

20-11-1997 NJ 1998, 392 (Hooymans/Hooymans);

JOR 1998, 26 m.nt. vd Ingh

6.4 .3

Hof Arnhew

26-05-1992 NJ 1993, 182 m.nt. Ma (Cniwest GroupBV)

Hof s-Gravenhage

01-10-1982 NJ1983,393 (Van Rees/Smits)

Hof s-Hertogenbosch

28-05-1957 NJ 1958, 129 (Schellens/Schellens)

3.7.4.2.

14-01-1999 NJ 1999, 743 (De Jong/Wichgers II)

Rechtbank Amsterdam

20-02-1985 NJ 1986, 113 m.nt. FHJM (Hadisantosol Flesseman q.q.)

Rechibank Breda

06-09-1994 NJ 1996,11

13-03-1998 JOR 1998,61 (De Jong/Wichgers D)

Rechbank "saGrowenhage

06-01-1949 N/ 1949,626(Giezen/Kan Lith)

Rechibank Rotrerdam

18-06-1990 KG 1990, 259 (Zegers/Zegers)

6.4.2.2. 


\section{Zuid-Afirika}

SA 1915A 491

'Estate Kemp and Others v McDonald's Trustee"

7.4 .2

SA 1925 CPD 516 'Sackville West v Nourse and another'

7.4 .3 .2

SA 1946 CPD 800 'Ex parte Knight and others'

SA 1965 (2) K 53

'Ex parte Attorneys, Notaries and etc'

7.4 .3 .2$.

'Braun Blann and Botha NNO and another'

7.4 .2 .

5.4 .

$\mathrm{SA} 1994$ (4) CPD52!

SA 1999 (1) SCA 551

'Cooper $\checkmark$ Boyes $\mathrm{NO}^{\prime}$

7.4 .3 .2 and another" 


\section{CURRICULUM VITAE}

Erwin Christiaan Bos werd geboren op 23 september 1975 te Vorden. In 1993 behaalde bij zijn Atheneum-diploma aan het Baudartius College te Zutphen. In 1994 volgde hij een senior year aan de Nashoba Regional High School te Bolton, Ma. in de Verenigde Staten. Hij studeerde in 2001 af in Nederlands Recht aan de Universiteit Maastricht. Na het doctoraalexamen was hij werkzaam als promowendus en docent aan de Faculteit der Rechtsgeleerdheid van de Universiteit Maastricht. Sinds april 2005 is hij werkzaam als advocaat bij Clifford Chance LLP te Amsterdam. 
Serie vanwege het Van der Hieijden finstitnut te Nijmegers onder feiding wan prof. mr. IMM Maejer, prof, mr. H.M.N. Schonis; prof. mr. F. P. van den Ingh, prof. ma. G. van Solinge, prof mir M. van Offen en prof. mr. M.P. Nieuwe Weme

1. Mr. W.J.M. Noldus, Ongeldigheid van besluiten in de naamloze vennootschap (1969)

2. Mr. P.A.L.M. van der Velden, De vereniging-rechtspersoon en haar Jeden (1969)

3. Mr. P.R. Smits, De externe gebondenheid van thet wennootschapsvermogen (1969)

4. Mr. J.A.Th.J.M. Duynstee, Beschot wingen over de stichting naar Nederlands privaatrecht (1970)

5. Mr. J.H.F. Cremers, Prioriteitsaandelen (1971)

6. Mr. M.M. Mendel, Het statutaïre doell van de maanloze vennootschap (1971)

7. Prof. mr. W.CL. wan der Grinten, wr. W. Westbroek, prof. nr. IMM. Maeijer en prof mr. P. Sanders, Het nieuwe vemootschapsrecht (1972)

8. Mr. A.M. Brenninkmeijer, Stemovereenkonsten van aandeelhouders (1973)

9. Prof. mr. W.C.L van der Grinten, prof. mr. J.M.M. Maeijer, mr. S.J.H. Huijben en nr. A.G. Lubbers, De nieuwe structuur van de grote $\mathrm{NV}$ en $\mathrm{BV}$ (1973)

10. Prof. mr. C.E.E. Uniken Venema, Misbunik van voorwetenschap (1974)

11. Mr. A. Plate, Niet wolgestorte arndellem (1974)

12. Mr. P.W.H.M. Francissen en mr. J.M. Jansen, Statuten van de grote NV en BV (1975)

13. Prof. mr J.M.M. Maeijer, prof. dr. W. Albeda, prof. mar. W.C.L. van der Grinten en prof drs. H.W. Lambers, Problemen bij fusie van NV en BV (1975)

14. Mr. M.M.G.C. Raaijmakers, Joint ventures (1976)

15. Mr. P.W.H.M. Francissen en mr. P.F.M. van Lierop, De ondernemingsraad (1977)

16. Prof. mr. J.M.M. Maejjer en prof. mr. J. Ronse, De vertegenwoordiging van rechtspersonen naar Nederllands en Belgisch recht (1978)

17. Mr. T.J. van der Ploeg, Het Burgerlijkk Recht en de vrijwillige organisaties. Beschouwingen n.a. w de regeling van de vereniging en de stichting in Boek 2 BW (1978)

18. Prof mr. I.M.M. Maeijer, mr. W. Westbroek, prof. mr. W.C.L. van der Grinten en mr. Y. Selholten, Het wennootschapsrecht en de Tweede EEG-Richtlijn (1979)

19. Mr. H.J.M.N. Honee, De benoeming wan conmissarissen bij grote vennootschappen (1979)

20. Prof. drs. J.W. Schoonderbeek, prof. Ar. W. van Bruinessen, prof. mr. JM.M. Maeijer, prof. mr. W.C.L. van der Grinten, mr. W.J.M. Gitmans, De jaarrekening en de Vierde EEG-Richtlijn (1981)

21. Mr. HJ.M.N. Honée, Concernrecht en medezeggenschapsregelingen (1981)

22. Prof. mr. J.M.M. Maeijer, prof. mi. W.C.L. van der Grinten, prof. mr. H.M.M. Honée, nr. A.G. van Solinge, mr. G.M.J. Ackermans, Ondernemingsraad en Vennootschap (1982)

23. Mr. dr. P. Vlas, Rechtspersonen in het internationaal privaatrecht (1982)

24. Mr. F.K. Buijn, De oprichting van de NV en de BV (1984)

25. Prof. dr. M. Lutter, mr. W. Westbroek, prof. mr. H.M.M. Honée, prof. mr. I.M.M. Maeijer, mr. G.M.J. Ackernans, De besloten vennootschap (1985)

26. Prof: nur. H.J.M.N. Honée, Contacten tussen commissarissen en ondernemingsraad (1986)

27. Mr. C.A. Schwarz, Blokkering wan aandelen (1986)

28. Mr. J. Lievens, prof. mr. H.JM.N. Honée, prof. mr. W.C.L van der Grinten, prof mi. JM.M. Maejier, prof. mr. P. van Schilfgarde, mi. drs. H. Langman, mr. J. Bloemarts, mr. G. Noordraven, mw. mr. M.J. Zelderirust-Visch, Financiële kruisverbanden en andere aspecten wan concenfinanciering (1987)

29. Mr. Th,C.M. Hendriks-Jansen, Verrnogensbescherming en persoonlijke aansprakelijkheid bij de besloten vennootschap (1988)

30. Misbruik van woorwetenschap. Uitgeve op initiatief van Actioma, Juridisch Faculteitsblad Katholieke Universiteit Nijmegen, ter gelegenheid van zijn 10-jarig bestaan (1989)

31. Mr. P.J. Dortmond Enige beschow wingen rondom aandelen (1989)

32. Mr. R.P. Voogd, Statutaire beschermingsmiddelen bij beursvemootschappen (1989)

33. Mr. M.P. van Achterberg, De jutidische definitie van het economische verschijnsel concen (1989) 
34. Dr. K Geens, prof mr. WCL van der Grinten, mr. R.P. Voogd, mr. A.G. van Solinge, nur. H.M.N.

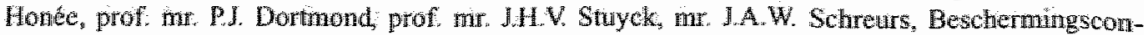
structies $(1990)$

35. Mr. F.l.P. wan den high, Certificering en certificat wan alandeel bij de besloten wennootschap (1991)

36. Mr. G. Noordraven, De regeling wan de Ubersehuldung (1991)

37. Prof, mr. J.M. Maeijer, prof mr. drs. H. Beckman, prof. mr. S.CIJ. Kormam, mr. FH.A. Arisz, mr. M.E. Engelaar. Aansprakelijkheid en dragaplicht van bestuurders, commissarissen en accountants, verzekerings saspecten (1991)

38. Mr. A. Voüte, Aandelen voor werknemers (1991)

39. Mr. H.M N. Honé prof mr P.J. Dortmond, mr H.I de Bijll Nachenius, dr. H.O.C.R. Ruding, mr. M.W. den Boogert, nit C.W.A. Tumermans, prof mr. H.MN. Schonis, mw mr. M.E. Engellaar, mr. J.A.W. Schreurs, Giterisowersehrijdende samenwerking van ondernemingen (1992)

40. Mr. D.R. Dootenbos; Financieel strafrecht (1992)

41. Mr. B.C.M. Waaijer, Statuten en statutenwijziging (1993)

42. Mr. L.G.H.J Houwen, mr. drs. A.P. Schoonbrood-Wessels, mir. J.A.W. Schreurs, Aansprakelijkheid in concernverhoudingen (1993)

43. Mr. FJ.P. wan den Ingh, prof. mr. S.C.J. Kortman, drs M.JM. Buiting, mr. N.E.D Faber, mr. R.W.Th. Norbnuis, mr. J.W. van der Staay, Converteerbare obligaties en aandelen (1993)

44. Mr: Gerard van Solinge, Grensoverschrijdende juridische fusie (1994)

45. Mr. R.J.C. van Gelden, mr. O.L.O. de Witt Wijnen, mr. A.G. wan Solinge, prof. mr. P.J Dortmond, prof. mr. J.M,M. Maeijer, mr. H.J.M.N. Honée, mr. E. Boswinkel, mw. mr. J. Roest, Problemen rondom de algenene vergadering (1994)

46. Mr: M.E. Schreurs-Engelaar; Organen van de coöperatie (1995)

47. Prof. mr. J.M.M. Maejer, prof. mir. H.M.N. Schonis, prof dr. A.H.M. Daniels, prof. dr. PHJ. Essers, Fiscale en civielrechtelijke aspecten van de commanditaire vennootschap (1996)

48. Mr. J. Roest, Medezeggenschap van werknemers bij financieeleconomische besluiten (1996)

49. Mr. J.J.A. Hamers; Verpanding van aandelen en de beslotenheid van kapitaalvennootschappen (1996)

50. Prof. mr. J.R. Schaafsma, prof. mr. S. Perrick, mr. D.H. Cross, prof mr. L. Timmerman, mr. F.G.B. Graaf, prof. mr. J.M.M. Maeijer, mr. H.M.L. Dings, mw. mr. J. Roest, Ontwikkelingen in het effectenverkeerstecht (1996)

51. Preadvies woor de Vereniging voor Effectenrecht 1994, Civielrechteilike gevolgen van handelen in strijd met effectenregelgeving, prof, mr. W.C.L. van der Grinten, prof. mr. S.C.J.J. Kortmann, prof. nur. S. Perrick (1996)

52. Mr. drs. C.M. Grundmann-van de Krol, mr. F.J.P. van den Ingh, Parlementaire Gesehiedenis van de Wet toezicht effectenverkeer 1995 (1996)

53. Mr. MA: Blom „Prospectusaansprakelijkheid van de lend manager (1996)

54. Mr. J.W. Bellingwout, Zetelverplaatsing van rechtspersonen (1996)

55. Preadvies voon de Vereniging voor Effectenrecht 1996 , Bewaring en eigendom wan effecten, mr. W.A.K. Rank, mr. E.M. wain Ardenne-Stachiw, mr. Ch.W. le Rütte (1997)

56. Mr. Y.L.L.A.M. Delfos-Roy, Informatieverstrekking en informatievergaring in het kader wan de toezichthoudende en radadgevende taak van de Raad van Commissarissen (1997)

57. Maeijers belangstelingen. Prof, mr. F.J.P van den Ingh, prof. mar. C.A. Selhwar, prof mr. H.J.M.N. Hone, prof. nor. P. van Schilfgaarde, prof. mr M.M. Mendel, prof. mr. M.J.G.C. Raaijmakers, prot. mi: T.ll: van der Ploeg, prof. mr. A.L. Molu, prof. ds: W. wan Gerven, prof dr. K. Geens, prof. ma. J.M.M. Macijer (1997)

58. Lustrumbundel Vereniging woor Effectenrecht 1997, De opkomst van een rechtsgebied, mr. R.I.V.F. Bertrams, mr. S.A. Boele, mi. D.H. Cross, prof, mr. S.E. Eisma, mr. C.M. Grundrnann-wan de Krol, mr. W. de Jong, mr. A.F.J.A. Leijten, mr. A. Nederveen, prof, mr. M.J.G.C. Raajmakers, prof. mr. W.A.K. Rank, mr. V.G. de Serière, prof. mr. WJ. Slagter, prof. nur. L. Tummerman, mr. L.J.K Vincent (1997) 


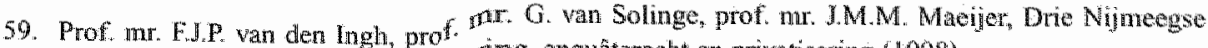

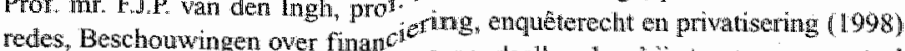

60. Mr. H.M.L. Dings, De commissie vath andee houders bij structuarvennootschappen (1998)

61. Preadviezen voor de Veremging vor Effectenredn 1999. Aspecten van toezicht, Beschowwinger ower het toezicht op de firanciale seotor m. H.G. van Everdingen, m. drs. C.M. Grundmam-van de Krol, mr. H.J. Sachse (1999)

62. Conflicten rondom de rechtsperso on, mr. A.EJA. Leijten, prof me. L. Timmerman, Mr. JMA. Willems, mr. R.A.A. Duk, prof, par. G. van Solinge, prof mr. P.J. Dortmond, mr. O.L. O. de Witt Wijnen (2000)

63. Preadvezen voor de Vereniging woor Effectentecht 2000 , Beleggingsinstellingen nader belicht, mr.drs. N. W. Ponsen, mr. P. Klemant (2000)

64. Prof. mr. M. vam Olffen, Beschermingsmaatregelen in de 2 le eenw (2000)

65. Woorkennis, toezich en boetes in niewwe financiële wetgeving, mr. D.R. Doovenbos, prof. mi. N.S.J. Koeman, mr. A. W. Docters wa Leeuwen, mu. A.J. Macro, mr. H.J. Sachse, ors. ing. C. Mags, mr. D.J.R. Lemstra (2000)

66. Preatviezen voor de Vereniging vor $\mathbb{E}$ ffectentecht $200 \%$, Effectenverkeer via intemet. Een tussenstand wanuit effectentechtelijk perspectief, drs. E.E. Feitsma, m. W.G. van Leeuwen, m. L.A.G. Moelker, mr. W. de Jong (2001)

67. Verspreide Geschriften wan E. I. wan der Heijden. Verzaneld door C. J.H. Jansen on G. varn Solnge (2001)

68. Geschriften vanwege de Vereniging Corporate Litigation $2001-2002$, onder redactie van prof. rui. $\mathrm{G}$. van Solinge en mr. M. Hollzer (2002)

69. Concernverhoudingen, prof. mr. L. Timmerman, prof mu. W.J.P. van den llngh, mur. S.M. Bartman, mr. L.G. Verburg, mr. M.L. Lennarts, prof. mr. Mn.A. van Mourik, mr. D.R. Doorenbos, prof. nur. M. wan Olfen (2002)

70. Preadvies voor de Vereniging voor Effectenrecht 2002 , De afwikkeling van grensoverschrijdende ef. fectentransacties, nr. B.M. wan Beek en mr. D. van Bruggen (2002)

71. Lustrumbundel Vereniging voor Effectenrecht 2002 , Eer bewezen bestanansecht (2002)

72. Geschriften vanwege de Vereniging Corporate Litigation 2002-2003, onder redactie van prof mr. $\mathrm{G}$. van Solinge en mi. M. Holtzer (2003)

73. Mr. M.S. Koppert-van Beek, Handelen mamens een op te richten vennootschap (2003)

74. Personenvemnootschappen, prof. mr. G. van Solinge, prof. mr. PJ. Dortmond, prof. mr. M.M. Maejer, mr. J.A.M. ten Berg, prof. mur. M. van Olfen, prof, mr. M. J.A. wan Mourik, prof. mr. A.L. Mohr en prof. mr. H.M.N. Schonis (2003)

75. Geschriften vanwege de Vereniging Copporate Litigation 2003 -2004, onder redactie van prof mu: $\mathrm{G}$. var Solinge en nr. M. Holtzer (2004)

76. De werknemer in het ondernemingsnecht, prof mo. L. Timmernan, prof. mi. $G$. van Solinge, nut

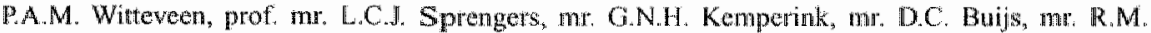
Bellzer, mr, EB.J. Grapperhans, prof, mr. I.P. Asscher-Vonk, mr. R.A.A. Duk (2004)

77. Verspreide Geschriften van W.C.L. Wan der Grinten. Verzameld en ingelelid door C.J.H. Junsen, S.C.J.J. Kortmann we van Solinge (2004)

78. Richtlijuen voor de onderzoeker in enquêteprocediues, mr. J.M. Blanco Fernăndez, mi: M. Halıkr, prof. mx. G. van Solinge (2004)

79. Mr. J.J. Prinsen, Converteerlatre obligaries (2004)

80. Mr. M.P. Nicuwe Weme, Het verplichit bod op effecten (2004)

81. Preadvies voor de Vereniging woor Ef fectenrech 2004. Voorstel wan Wet op thet financieel woericht, mr. J.M. van Dijk en mr. H. V. Oppelatar (2004)

82. Geschriften vanwege de Verenging Corporare Lugation $2004-2005$, onder redactie van prot. mr. $\mathrm{G}$. van Solinge, mr. M. Holter en mr. A. F.J.A. Leijten (2005)

83. Mr. G.J.C. Rensen. Extra-verplichtingen wan leden en andeelhouders (2005)

84. Mr. E.C. Bos, Vruchigebruitk op and an len (2005) 